UNIVERSIDADE DE SÃO PAULO

DEPARTAMENTO DE ARQUEOLOGIA E ETNOLOGIA

PROGRAMA DE PÓS-GRADUAÇÃO EM ARQUEOLOGIA

\title{
As Escadas da Arquitetura Minóica do Período Palacial
}

Karin Shapazian

Dissertação apresentada ao Programa de PósGraduação do Departamento de Arqueologia e Etnologia da Universidade de São Paulo, para obtenção do título de Mestre em Arqueologia.

Orientadora: Profa. Dra. Haiganuch Sarian

São Paulo

2006 
À minha sobrinha Gabriela Araújo Shapazian 


\section{AGRADECIMENTOS}

Ao Prof. Alvaro Allegrette, pela orientação, apóio, confiança, estímulo e amizade.

À Profa. Haiganuch Sarian, pela confiança e oportunidades que ela sempre me cedeu.

À École Française d'Athènes por possibilitar o acesso e uso de seus recursos e por permitir a visita ao sítio de Mália.

À minha família, principalmente à minha irmã, pelo seu auxílio, apoio e amor constante. 
Dissertação de Mestrado

\section{$\underline{\text { As Escadas da Arquitetura Minóica do Período Palacial }}$}

\section{RESUMO}

Através da pesquisa dos elementos verticais, presentes na maioria dos edifícios da cidade de Mália do período palacial (2300-1480 a.C.), temos como objetivo nesta dissertação de mestrado analisar a organização tridimensional das construções, tanto as privadas como as públicas.

A investigação inicialmente parte das noções do conhecimento de todas propriedades e características desses mega-artefatos, os edifícios. Em seguida, busca identificar padrões e regularidades, analisando os materiais, as técnicas e as disposições das escadarias inseridas nas construções, para assim poder compreender o papel do elemento vertical na percepção do espaço entre os minóicos, a tridimensionalidade de seus edifícios, suas restrições e possíveis reestruturações de funções, pois o que restou dessas construções são apenas as rotas horizontais. Tenta-se identificar as concepções que levaram seus usuários a optar por verticalizar suas cidades.

Esta pesquisa revela que os elementos verticais são essencias na paisagem em relação aos aspectos espaciais construídos; definem edifícios que se destacam e modificam o território onde viviam os minóicos.

Palavras-chaves: escada, arquitetura, civilização minóica, Idade do Bronze 


\section{Staircases of Minoan Architecture in the Palatial Period.}

\section{ABSTRACT}

Through the research of vertical elements, which are prevalent throughout the majority of the buildings in the palatial city of Malia (2300-1480 a.C.), we aim to analyze the spatial organization of tri-dimensional constructions, in both private and public buildings.

The investigation is initially based on the notions of the knowledge of all the properties and characteristics of those mega-artefacts, the buildings. Then, identify patterns and regularities, analyzing the material, the techniques, and the layout of staircases built into the constructions, as to achieve a deeper understanding of the role the vertical element played in the perception of space among the minoans, their tridimensionality techniques, the restrictions and the possibility of restructuring functions, since what is left of the constructions is only the floor plan. We attempt to identify the conceptions that led the users to choose to make their cities vertical.

This research shows how essential the vertical elements are in the landscape when built spacial aspects are concerned; they define buildings which stand out and modify the territories where the minoans lived.

Key words: staircase, architecture, minoan civilization, Bronze Age 


\section{SUMÁRIO}

Agradecimentos

\section{Resumo}

Abstract

Sumário

Introdução

1. Considerações Gerais 9

$\begin{array}{ll}\text { 1.1. Cronologia } & 13\end{array}$

1.2. Ocupação do Sítio de Mália 15

2. Características da Arquitetura Minóica 18

2.1. Organização do Espaço Privado 26

2.2. Organização do Espaço Público 31

2.3. Pavimentos Superiores 36

2.4. Materiais e Técnicas de Construção 48

$\begin{array}{ll}\text { 2.5. Escadas } & 60\end{array}$

3. Catálogo das Escadarias 72

3.1. Edifícios Privados 73

3.2. Edifícios Públicos 107

4. Análise Geral 145

$\begin{array}{ll}\text { Conclusão } & 164\end{array}$

$\begin{array}{ll}\text { Bibliografia } & 166\end{array}$

$\begin{array}{ll}\text { Lista de figuras } & 173\end{array}$ 


\section{INTRODUÇÃO}

Foi no final do século XIX que o arqueólogo Sir Arthur J. Evans descobriu ruínas monumentais de uma civilização ainda desconhecida para o mundo da história da cultura grega. Sir Arthur dedicou-se por mais de 30 anos da sua vida à escavação e pesquisa dessas ruínas, revelando assim o palácio de Cnossos, e denominando essa nova cultura, que antecede a grega, de civilização minóica, em referência ao lendário rei Minos, o mais famoso monarca desta civilização e responsável pela construção do labirinto do Minotauro. Ao longo do século XX outras pesquisas abriram caminho para as descobertas dos palácios de Festos e de Mália, sendo estes, mais Cnossos, os três maiores centros urbanos da ilha de Creta.

As escavações na cidade de Mália pela École Française d'Athènes desde 1922, descobriu não só uma grande estrutura, o palácio, como também um núcleo urbano dos mais importantes na ilha de Creta, durante a Idade do Bronze (cerca de 3000-1450 a.C.). As pesquisas perduram até os dias de hoje.

Nas últimas décadas, o estudo arqueológico adquiriu novos métodos de investigação com a New Archaeology, chamada também de arqueologia processual, e com a arqueologia pós-processual. $\mathrm{O}$ pensamento antropológico, especialmente nas áreas da evolução cultural, nas teorias dos sistemas e ecologia, tem afetado o estudo arqueológico e também na arqueologia minóica. Os sentidos a partir dos quais os arqueólogos conceituaram a cultura antiga foram maturados, principalmente, nas áreas de organização social, mudanças culturais e no meio ambiente. O número de pequenas escavações tem sido menor, porém mais precisas no registro dos achados e focadas em problemas específicos (WATROUS, 1994, p.698). Os pesquisadores têm adotado amplas abordagens para a interpretação do passado, 
com mais ênfase em métodos interdisciplinares.

Desde 1970, arqueólogos começaram a fazer novos questionamentos sobre a população minóica, o uso da terra e sua organização política das regiões da ilha. Questões que levaram a uma maior ênfase nos surveys e, hoje, graças a elas temos evidências detalhadas para o estudo dos padrões de assentamentos da Creta minóica (WATROUS, 1994, p.699). Com o resultado desses estudos, os pesquisadores atuais da arqueologia minóica encaram o registro arqueológico como sendo mais amplo e profundo, o único na proto história do Egeu.

Paralelamente, teorias sociais começaram a focar sob nova forma no âmbito espacial como também nas dimensões temporais do comportamento humano. Nesse contexto, antropólogos, arquitetos e urbanistas se envolveram na discussão de questões como: por que existem diferenças nos desenhos das formas, qual a natureza dessas diferenças e quais são os fatores sociais e culturais que podem ser responsáveis por essa variação? (LAWRENCE, 1990, p.453). No entanto, veremos que antes dessa análise em específico, podemos verificar que a paisagem é o fator pelo qual tais formas e pensamentos são criados, e principalmente, se averiguar que a arqueologia estudando o passado dos seres humanos tem, portanto, se interessado pelo espaço e conseqüentemente pelas paisagens.

A pesquisa se insere dentro desse contexto, as escadas das construções minóicas desde o protopalacial, período onde esse elemento apareceu na arquitetura, até o neopalacial, na cidade de Mália, Creta. A investigação tem como base principal a análise da documentação material publicada referente tanto à cidade de Mália como as pesquisas de outros sítios arqueológicos da ilha. Ela parte de um elemento arquitetônico em micro escala, para assim poder compreender seu uso e as mudanças que afetaram em um contexto mais amplo.

O elemento arquitetônico que será discutido é um dos mais complexos dentro da 
arquitetura, independentemente de época e lugar. Esse elemento, a escada, é o conjunto de suportes planos (degraus) fixos ou móveis escalonados que permitem a circulação das pessoas entre dois ou mais níveis. O arquiteto italiano Vicenzo Scamozzi escreveu, em 1615, que “dentre todos os elementos arquitetônicos, as escadas são para o edifício o mesmo que as artérias e as veias para o corpo humano. São imprescindíveis para a comunicação e nesse sentido a escada seria como o coração de um edifício, enchendo-o de vida" (citado por HANSMANN, 1994, p.10).

Entretanto, no sentido físico, as escadas servem como elemento de comunicação vertical para superação de diferenças de altura com reduzido gasto de energia humana.

Em uma observação mais ampla acerca das escadas, desde o seu planejamento prévio até seu uso, nota-se que nesse campo de trabalho não há espaço para especulações na hora da construção. É necessária a observação de vários aspectos: limite do terreno e construção; regras já estabelecidas como recuos e alturas; posicionamento para melhor aproveitamento do sol ou para proteção de ventos fortes; nivelamento topográfico ou não; estilo a ser adotado para não causar impacto no seu entorno; materiais escolhidos; aproveitamento ou não da vegetação que o terreno possui etc. E, principalmente, quando o profissional está na fase de projeto, é essencial observar o perfil do usuário que irá residir ou trabalhar na futura edificação. É importante saber quais são as necessidades do usuário: como os espaços internos e externos serão aproveitados, verticalidade ou horizontalidade, saber se algum usuário possui deficiência física, quantidade de pessoas que irão usar o lugar etc. Estudando o perfil do usuário o profissional conhece os valores, prioridades e entra na mente do mesmo.

A arquitetura é a arte de equacionar adequadamente forças, material, tempo e dinheiro, ordenamento, disposição, proporção, conveniência e distribuição do espaço. O 
arquiteto Perret fez uma excelente definição ao afirmar que a "arquitetura é a arte de organizar o espaço." Dessa maneira, Teixeira Netto disse que a arquitetura é "uma linguagem definida tanto quanto possível de antemão e que esteja ao alcance simultâneo do criador (profissional) e do receptor (usuário)" (TEIXEIRA NETTO, 1999, p 11). Essa arte também é a união de "material e ações espirituais que estão conectadas por rituais de construção que acontecem em vários pontos do processo. Este procedimento forma parte do complexo, atividade múltipla representada na construção que tem como essência o trabalho coletivo" (RAPOPORT, 1969 p.108).

Nas questões arqueológicas, seguimos os mesmo princípios, embora o raciocínio direcione-se em sentido inverso, já que o pensamento ou a formulação começa nos vestígios da construção e termina nos indivíduos. $\mathrm{O}$ arqueólogo se depara com os restos arquitetônicos deixados por antigos habitantes. Esses resquícios são componentes de cultura material muito significativos para o estudo arqueológico. Pois como o ex-primeiro ministro inglês, Winston Churchill, disse: "Primeiro nós damos formas a nossas construções e depois nossas construções nos dão forma" (citado por PEARSON e RICHARD, 1994, p.2).

Em uma outra relação, os pesquisadores Palyvou (1987) e Sanders (1990) deixam claro em seus estudos que as formas arquitetônicas podem providenciar uma grande variedade de pistas, símbolos e marcadores de orientação para os arqueólogos. Tais sinais são aspectos característicos de uma determinada cultura e são automaticamente compreendidos por esses que participam do mesmo contexto, no qual eles foram condicionados desde a infância. Nesse sentido, Rapoport afirma que o espaço tem significado cultural e comenta “... as formas, uma vez construídas, afetam o comportamento e a maneira de viver" e que "uma casa não é somente o resultado de força física ou qualquer único fator casual, mas é a conseqüência de diversos fatores sócio-culturais vistos nas condições do mais extenso termo" (RAPOPORT, 
1969, p.47).

Devido aos fatores observados sobre o sentido arquitetônico, as escadas fazem parte desses aspectos e permitem uma melhor tridimensionalidade do espaço, mais ainda que qualquer outro elemento arquitetônico. Adquirem a devida relevância, podendo introduzir-se adequadamente na arquitetura como um elemento configurador de fachadas, de conexão, estético e funcional.

As vias verticais abordadas nessa pesquisa são as de transição, que separam duas paisagens inteiramente distintas. Acesso do térreo para o nível superior, e assim por diante. Não serão retratadas as escadas que tinham como objetivo o desnivelamento topográfico, ou seja, o desnivelamento do solo dentro do mesmo espaço.

A escolha pelas vias verticais de transição é devido às suas diferentes funções. As escadas não são tratadas apenas como elementos de circulação, pois o estudo é direcionado também para os aspectos de demarcação territorial e fronteiriço (PALYVOU, 1987; SANDERS, 1990; ALLEGRETTE, 1991; HANSMANN, 1994; NUET, 1994) abrangendo as diferentes concepções que levaram à construção de escadas para diferenciar um pavimento do outro, tendo como finalidade o objetivo de definir o uso e a organização desses diferentes pavimentos. O objetivo dessas observações nesta pesquisa é a verificação da existência de padrões ou a regularidade do uso dos elementos verticais.

O problema da necessidade da verticalização das construções na civilização minóica também está sendo levado em consideração. O que teria levado aquela população a escolher ampliar suas cidades nessa direção?

Essa questão será levantada para observação do processo de desenvolvimento das construções minóicas do período protopalacial, considerando sua evolução e colocação da 
hipótese de a introdução do elemento vertical estar relacionada à ampliação das cidades nesta direção, resultando no projeto urbano cristalizado no período posterior, o neopalacial.

A pesquisa foi feita tendo como referência os sítios urbanos e palaciais da ilha, como os palácios de Cnossos, de Festos e de diferentes locais de relevância para o estudo, como as casas Xeste 2 e 3 da cidade de Acrotiri, Santorini. Esses edifícios são construções datadas dos períodos protopalacial e neopalacial e serão usados como parâmetros a ser estabelecidos entre elas e as construções da cidade de Mália.

Finalmente, o estudo mais detalhado do projeto arquitetônico e da execução das escadas é recuperar a percepção, o planejamento prévio de seus construtores, e descobrir se o uso de escadas originou-se primeiramente nos palácios ou nas casas, portanto, definindo uma origem e desenvolvimento deste dispositivo na arquitetura oficial e vernacular minóica, podendo considerar influências (ou não) do Egito e da Mesopotâmia na ilha.

A pesquisa se apóia em diversas obras bibliográficas. Os relatórios de escavações dos pesquisadores da École Française d'Athènes, assim como pesquisas mais aprofundadas da civilização minóica (GRAHAM, 1962; EFFENTERRE, 1980; PELON, 1980), nas mais específicas (SHAW, 1973; PREZIOSI, 1983; ALLEGRETTE, 1991 e 1997) e nos estudos de análise do espaço residencial e palacial (DRIESSEN, 1987; SANDERS, 1990; HALLAGER, 1990; SCHOEP, 1994; PALYVOU, 2001), como também nos estudos construtivos da arquitetura (HANSMANN, 1994; TEIXEIRA NETTO, 1999; HUGON, s.d.) entre outros. 
A estrutura que segue a pesquisa compreende as seguintes partes:

No primeiro capítulo, abordaremos as considerações gerais da região de Mália e sua constextualização. Em seguida mostraremos a tabela cronológica e ao delineamento do processo de ocupação da cidade de Mália.

No segundo capítulo, apresentaremos as características gerais da arquitetura minóica, depois direcionaremos para a organização de diferentes espaços construídos e ocupados, do privado ao público. Em complemento às características mostraremos os materiais e técnicas dessas construções e a partir desse levantamento discutiremos as hipóteses e onde foram baseados os pavimentos superiores, para assim expor os dados do elemento em questão dessa pesquisa, as escadarias: sua definição, importância e configurações; as técnicas minóicas em comparação aos princípios básicos de construções atuais, e expor os critérios com base nas quais faremos a identificação das escadarias dos edfícios maliotas.

O terceiro capítulo consiste no catálogo das escadarias e a análise detalhada das estruturas onde elas estão inseridas. Apontaremos as evidências de escadarias nos edifícios privados e públicos, nas suposições levantadas por pesquisadores e também nos dados levantados e nos critérios anteriormente estabelecidos que possibilitarão a identificação de escadas sem indícios diretos (os degraus).

O quarto capítulo aborda as diversas análises da organização espacial dos edifícios através das informações obtidas na catalogação. Neste capítulo, parte do conhecimento técnico e construtivo e posteriormente a leitura e interpretação dos marcadores de orientação dos antigos usuários no dinamismo vertical da circulação interna das 
construções. Demarcando, dessa maneira, território e fronteira, determinando padrões e regularidades do uso dos elementos verticais, sua importância simbólica, artística, tecnológica e paisagistíca, para assim responder as perguntas citadas na introdução do trabalho: onde elas se originaram primeiramente, nas casas ou nos palácios? Qual foi a necessidade da verticalização, por que a cidade ampliou-se dessa maneira? Quais são os usos e funções das escadarias na arquitetura minóica?

A conclusão é a apresentação de um balanço dos resultados e das perspectivas obtidas a partir da análise efetuada no capítulo anterior.

O desenho técnico faz parte constante do estudo, resultando em uma melhor visualização e clareza dos procedimentos e aspectos utilizados nas construções analisadas. As imagens e as fotos sem crédito específico são de autoria própria. 


\section{Considerações Gerais}

Na ilha de Creta, durante a Idade do Bronze, floresceu a civilização minóica, que tem um lugar proeminente na história da cultura grega. Essa civilização era praticamente desconhecida até o fim do século XIX, embora houvesse pistas de sua existência na Ilíada e na Odisséia. Constituiu um dos principais eixos de desenvolvimento do Mediterrâneo Oriental durante quase toda a Idade do Bronze (cerca de 3000-1450 a.C.) (ALLEGRETTE, 1997, p.1).

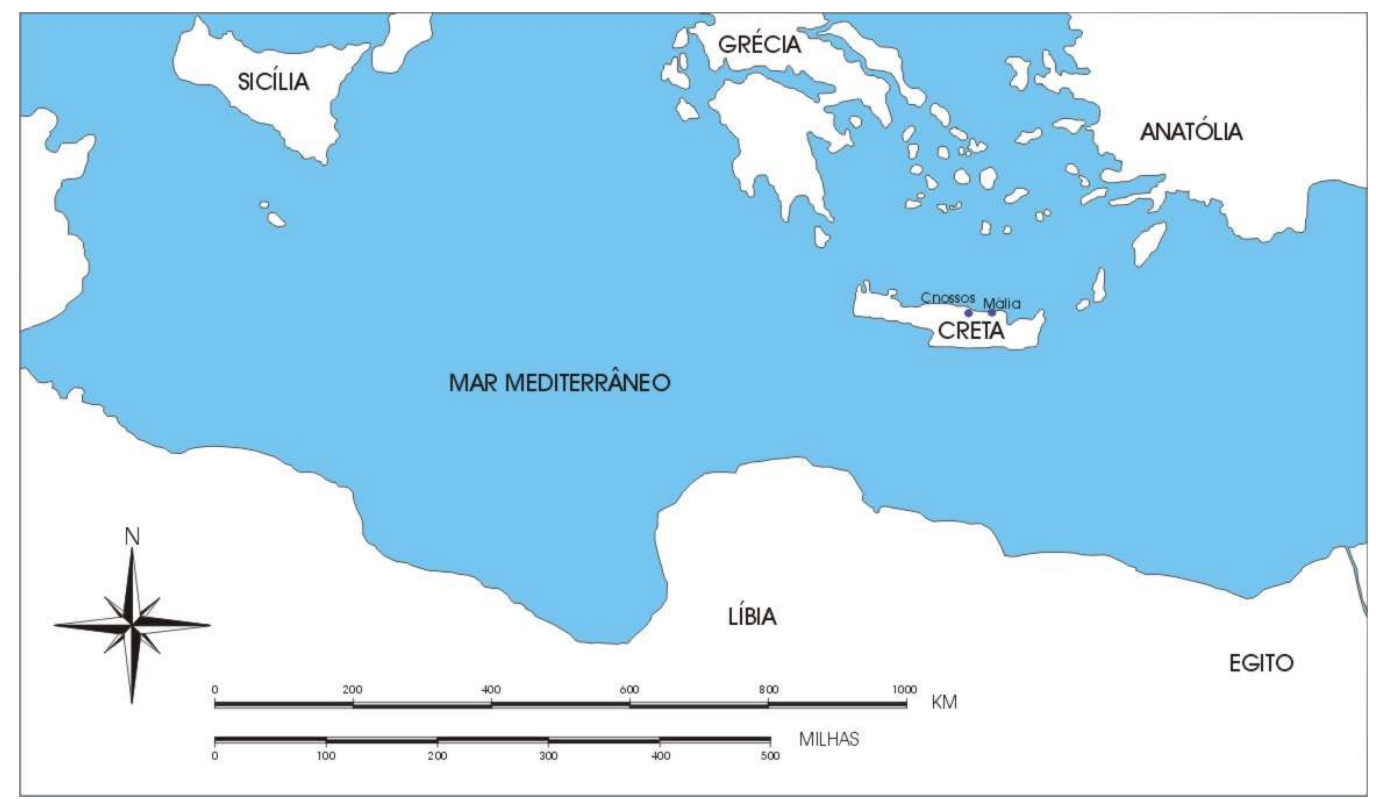

Fig. 1: Localização da ilha de Creta

Uma dessas características são suas situações geográficas, já que os principais palácios, Cnossos, Festos, Mália e Zacro, foram implantados na costa ou próximo dela (WARREN, 1998). Dentro desse quadro da ilha, o sítio de Mália está localizado na planície costeira ao norte, entre as montanhas de Ida e Dite, no ponto mais elevado dessa planície, sobre um pequeno platô com altura máxima de 15 metros, que permite uma visão ampla do 
oeste e da costa. A região possui uma série de formações rochosas de sideropetra e ammouda, recursos naturais que fazem parte do material básico das suas construções. Apesar disso, esta região não apresenta outras condições naturais favoráveis para o assentamento de uma cidade, apresentando: solo pobre, recursos hídricos limitados, terreno alagadiço na estação de chuva, seco e árido na estação seca, vegetação arbustiva.

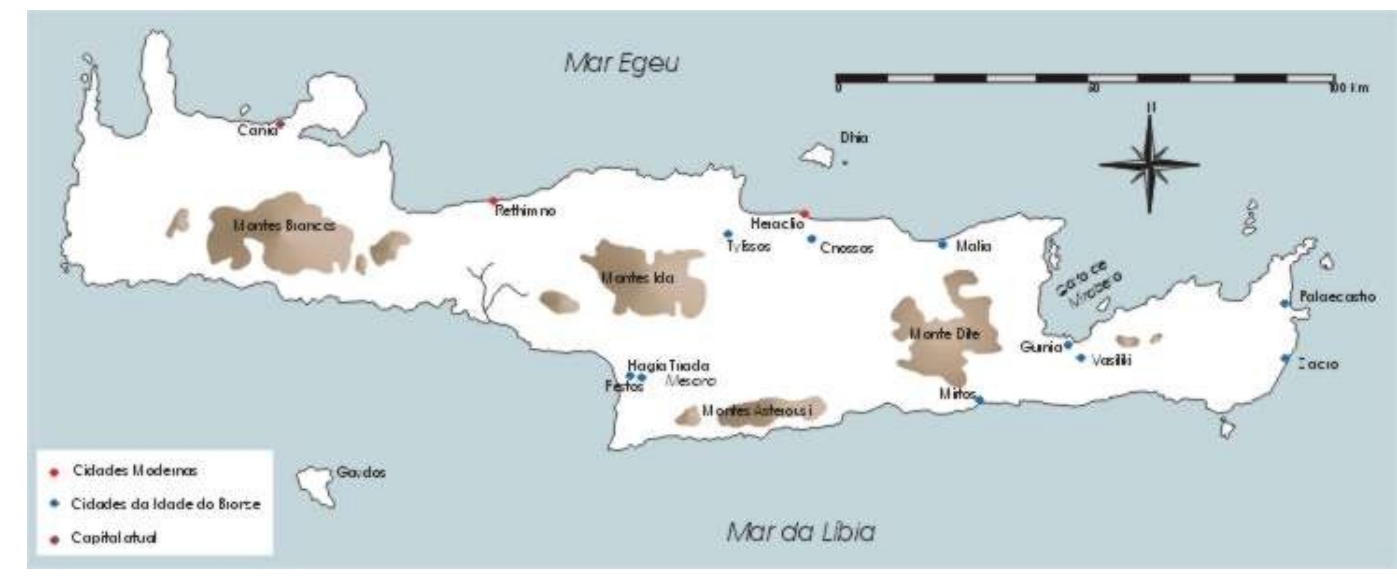

Fig. 2: Ilha de Creta e suas cidades.

Entretanto, o sítio esta localizado em um ponto estratégico entre o platô de Lasiti, onde se dá o acesso para outras partes da ilha, como para a cidade de Cnossos, assim como para uma área com uma produtividade agrícola elevada, e o mar com a possibilidade pesqueira e contatos comerciais com outras regiões litorâneas de Creta (ALLEGRETTE, 1991, p. 1-5).

A cidade maliota é um complexo urbano onde o palácio é o edifício central no período neopalacial, tanto de poder político, como religioso e econômico. À sua volta existem residências, oficinas, edifícios públicos, necrópoles etc. Os limites da cidade vão: da quadra Gama, a leste do palácio, até a necrópole de Chrysolakkos ao norte e até a casa Épsilon, ao sul. Os limites do sítio de Mália se estendem até a praia a Noroeste, onde se encontrou a quadra Teta (ALLEGRETTE, 1997, p. 188). 
listadas como se segue ${ }^{1}$ :

\author{
Villa Alfa \\ Quadra Gama (1924) \\ Casa Delta Alfa \\ Casa Delta Gama \\ Casa Épsilon alfa \\ Casa Zeta beta \\ Casa Theta \\ Casa Kappa gama \\ Casa Kappa delta 2 \\ Casa Kappa épsilon \\ Esplanada Norte (Ágora) \\ Batimênt Intermédiaire \\ Casa com Fachada Reentrante \\ Envasamentos Protopalaciais da Esplanada \\ Norte \\ Santuário do Minóico Médio II \\ Quadra $\mathrm{Mu}$ \\ Palácio \\ Nécropole des Pierres Meulières \\ Ossários \\ Setor Nordeste do Palácio
}

\author{
Edifício Beta \\ Quadra Gama (1930) \\ Casa Delta Beta \\ Quadra Épsilon \\ Casa Zeta alfa \\ Casa Zeta gama \\ Casa Kappa alfa \\ Casa Kappa delta $1 / 1$ bis \\ Casa Kappa delta 3/4 \\ Edifício Kappa beta (Cripta Hipostila) \\ Depósitos Meridionais da Esplanada Norte \\ Casa da Cave com Pilares \\ Casa dos Vasos com Estribo \\ Casas Dessenne \\ Santuário dos Cornos de Consagração \\ Quadra $\mathrm{Nu}$ \\ Casas Sul A, B e C \\ Edifício Funerário de Chrysolakkos \\ Casa de Hágia Varvara
}

Seu território se estende às montanhas Lasiti, de acordo com a extensão dos vestígios. O território da cidade correspondia a $500.000 \mathrm{~m}^{2}$, e a área do núcleo é de 100.000 $\mathrm{m}^{2}$ (ALLEGRETTE, 1991, p. 2). Segundo Van Effenterre, a população atingiria 10.000 habitantes em seu limite (EFFENTERRE, 1963, p. 51).

1 - Levantado por Allegrette (ALLEGRETTE, 2002, p.6). 


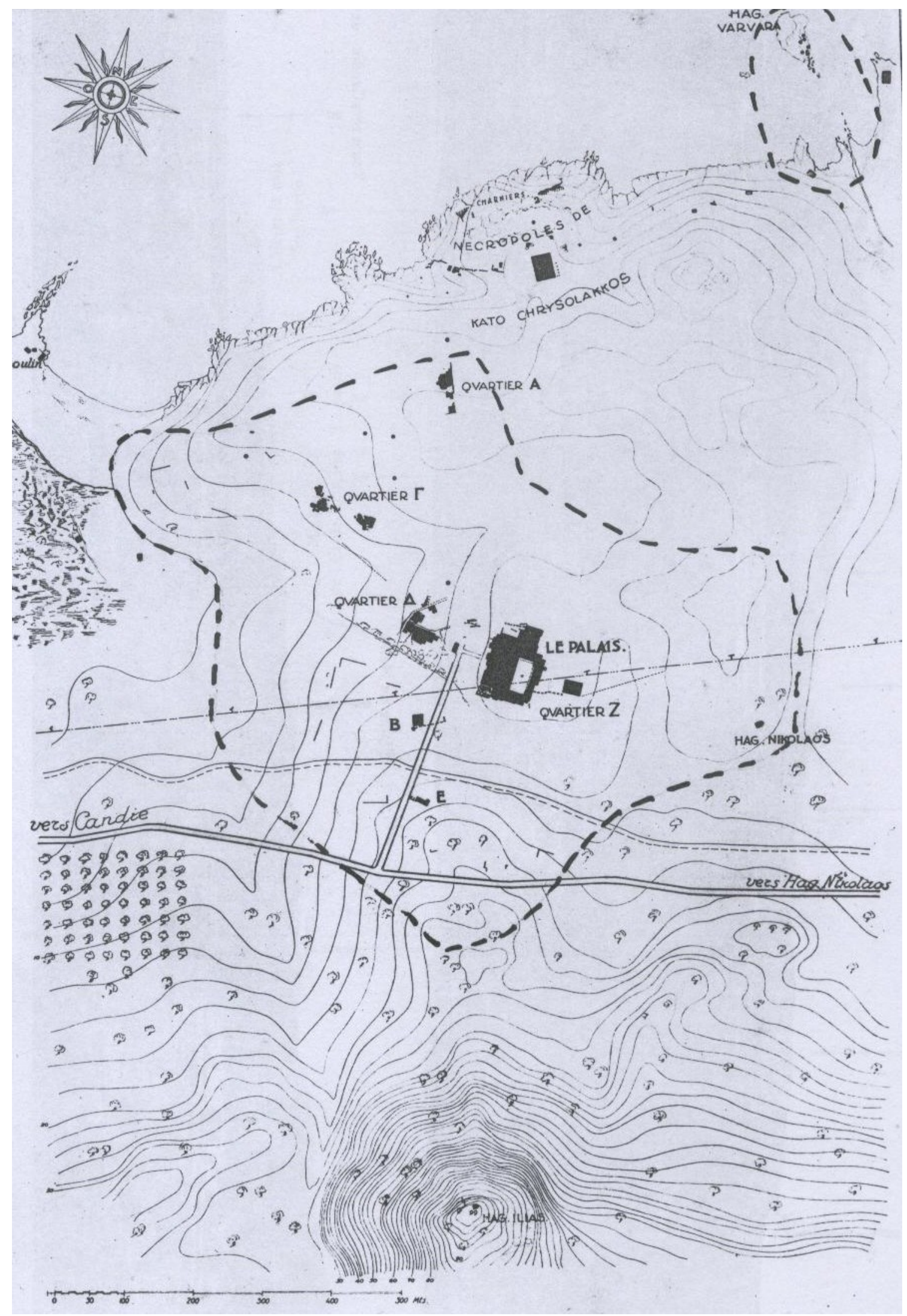

Fig. 3: Limite da cidade de Mália (DEMARGNE e SANTERRE, 1921-48, pl.1). 


\subsection{Cronologia}

A estratigrafia analisada por Evans em Cnossos levou-o a crer que a ocupação foi contínua. Dessa maneira, ele estabeleceu a cronologia em um grande quadro minóico, publicando-a em seu livro "The Palace of Minos", em vários volumes entre 1920-28. Essa terminologia da civilização minóica, sofre um processo de modificação e é motivo de discussão até hoje. Esse sistema cronológico foi estabelecido através da pesquisa das cerâmicas de Cnossos. Ao analisar qualidade, forma e decoração da cerâmica foi possível estabelecer três períodos: Minóico Antigo (3000 - 2000 a.C.), Minóico Médio (2000 - 1600 a.C.) e Minóico Recente (1600 - 1200 a.C.). Os três períodos foram subdivididos em fases (Minóico Antigo I, II, III, por diante) e depois essa subdivisão foi dividida em unidades indicadas por letras do alfabeto (Minóico Antigo IB) (HOOD, 1971, p.43).

Evans baseava-se, em primeiro lugar, nas alterações do estilo cerâmico de Cnossos, possivelmente o principal centro da ilha durante toda a Idade do Bronze. Embora a civilização de Creta fosse basicamente homogênea, havia diferenças locais e divergências de estilo na cerâmica (HOOD, 1971, p.41). Por esse motivo, a cerâmica não corresponde à cronologia dos outros palácios e por não considerar transformações históricas significativas no desenvolvimento da civilização minóica. Dessa maneira, o sistema foi revisado e reformulado por Friedrich Matz e teve como eixos as transformações econômicas e políticas e o desenvolvimento artístico notado nos palácios, resultando em uma periodização de aparências similar ao sistema de Evans, com três períodos e subdivisões.

Mais tarde, um novo sistema baseado nos achados de Festos e nos destroços do palácio foi gradualmente aceito. Esse sistema é fundamentado nos acontecimentos magnos da história de Creta. A maioria dos palácios sofreu grandes danos, talvez causados por terremotos, por volta de 1700 a.C. Os palácios foram reconstruídos em um estilo mais 
imponente, introduzindo no seu grande florescer cultural. Apesar de ter sido aceito, esse sistema é discutido até hoje (BIERS, 1987; GRAHAM, 1962; HOOD, 1971; WATROUS, 1994).

Um novo sistema chamado de "palacial" foi proposto por Nicolas Platon, na década de 60, na cronologia minóica. Ele dividiu a Era minóica em: Pré-palacial (correspondente ao período Minóico Antigo e provavelmente MM I A), Protopalacial (MM I e II, a destruição dos antigos palácios determinou o fim desse período), Neopalacial (MM III e MR I B e III A) e Pós-palacial (o resto do período MR III) (CADOGAN, 1976, p. 18).

Apoiaremo-nos na combinação de todos os métodos, usando principalmente a divisão do sistema de Platon. Segundo P. Warren e V. Hankey, Aegean Bronze Age Chronology, 1989 (citado por ALLEGRETTE, 1997, p. 226).

\begin{tabular}{|l|l|}
\hline Neolítico Recente (NR) & c. $3650 / 3500$ \\
\hline Minóico Antigo I (MA I) & c. $3650 / 3500-3000 / 2900$ \\
\hline Minóico Antigo II (MA II) & $2900-2300 / 2150$ (Pré-palacial) \\
\hline Minóico Antigo III (MA III) & $2300 / 2150-2160 / 2025$ (Início do Protopalacial) \\
\hline Minóico Médio IA (MM IA) & $2160 / 2025-$ s.XX \\
\hline Minóico Médio IB (MM IB) & s. XIX \\
\hline Minóico Médio II (MM II) & s. XIX - 1700/1650 (Fim do Protopalacial) \\
\hline Minóico Médio IIIA (MM IIIA) & $1700 / 1650-1640 / 1630$ (Início do Neopalacial) \\
\hline Minóico Médio IIIB (MM IIIB) & $1640 / 1630-$ c. 1600 \\
\hline Transição & c. 1600 \\
\hline Minóico Recente IA (MR IA) & $1600 / 1580-$ c. 1480 (Fim do Neopalacial) \\
\hline Minóico Recente IB (MR IB) & c. $1480-1425$ (Início do Pós-Palacial) \\
\hline Minóico Recente II (MR II) & $1425-1390$ \\
\hline Minóico Recente IIIA1 (MR IIIA1) & $1390-1370 / 1360$ \\
\hline Minóico Recente IIIA2 (MR IIIA2) & $1370 / 1360-1340 / 1330$ \\
\hline Minóico Recente IIIB (MR IIIB) & $1340 / 1330-$ c. 1190 \\
\hline Minóico Recente IIIC (MR IIIC) & c. $1190-$ c. 1070 \\
\hline Subminóico & c. $1070-$ após 1015 \\
\hline
\end{tabular}




\subsection{Ocupação do sítio de Mália}

Primeiramente, as evidências de instalação de um grupo humano no sítio de Mália são a partir do período Pré-Palacial (MAII - 2900 a 2300/2150 a.C., in WATROUS, 1994, p.709). São restos de paredes localizados sob a sala I1 do palácio e na região da "ágora", compostos por blocos de calcáreo azul e seixos ligados por argila, com uma espessura média de 50 a 60 cm, formando ângulos retos. Associados a estes restos arquitetônicos temos grande quantidade de fragmentos de cerâmica do estilo Vasiliki, atestada em uma faixa que se estende da quadra Kappa, a leste do palácio, até a necrópole de Chrysolakkos ao norte e a casa Épsilon ao sul. Nesta fase o pesquisador Watrous sugere que já haveria um desenvolvimento paralelo entre Cnossos, Festos e Mália, caracterizado pela ampliação da área do assentamento e pela formação de uma estrutura social hierárquica nestes núcleos (WATROUS, 1994, p.713).

Para o período MA III - MM I A (2300/2150 a 1900 a.C.), se define o arqueopalacial, termo criado pelo pesquisador Van Effenterre para Mália, que aponta uma intensificação da vida urbana, a aparição de uma malha de ruas e a delimitação do recinto da cidade (EFFENTERRE, 1980, p.29). Já para Pelon este foi o período das primeiras construções das estruturas palaciais. Observa-se ainda a presença de habitações na parte sul do palácio, as casas Sul, além de camadas de nivelamento sob a casa Épsilon e a quadra Mu. (PELON, 1970, p. 75-76, citado por ALLEGRETTE, 1991, p.9).

O período Protopalacial, MM IB - MMII (1900 a 1700/1650 a.C.), foi dividido em duas fases: MM IB (1900-1800 a.C.), identificado pela cerâmica Camares Antigo e a segunda fase MM II (1800 - 1700/1650 a.C.), pela presença do Camares Clássico.

A primeira fase do protopalacial é marcada pelo surgimento de construções de 
habitações sobre áreas anteriormente desertas, que se estendem da quadra Teta, próximo à praia do Moinho, até a quadra Delta, incluindo as quadras Gama, Kapa, a ágora e a Cripta Hipostila e talvez a Épsilon e Zeta (POURSAT, 1988, p.72, citado por ALLEGRETTE, 1991, p. 11).

A quadra $\mathrm{Mu}$, um aglomerado de habitações e oficinas a noroeste do palácio, sobre restos de habitações do $\mathrm{MM}$ IB, foi construída na segunda fase. Existem sinais de reconstrução nas quadras Teta e Gama, com alteração do plano anterior. Quanto ao edifício do palácio, existem vestígios de paredes e pavimentos nas áreas das quadras I, III, VI, X, XI e XXVII, além de material proveniente de sondagens nas áreas das quadras IX, XVII, XIV, IV, III, XXVIII.

Neste período existem sinais de destruição assinalados no sítio entre o MM II e o MM III, acompanhados ou provocados por incêndios, atingindo todas as construções existentes (PELON, 1982, p.180-183, citado por ALLEGRETTE, 1991, p.12; WATROUS, 1994, p.729).

O período Neopalacial, MM III - MR IA (1700/1650 - 1480 a.C.) é evidenciado por duas fases distintas no âmbito arquitetônico, correspondendo a etapas diferentes de desenvolvimento do núcleo maliota. O MM III tem como característica a ocupação de áreas periféricas àquelas utilizadas no período anterior à destruição do MM II - MM III e a construção do edifício palacial que atualmente se encontra exposto. O MR IA é a fase em que se define o núcleo de Mália na sua extensão máxima e o palácio na sua forma definitiva. As habitações se localizam em áreas idênticas ou correlatas às do MM III, como as casas Delta Alfa, Épsilon, Zeta Alfa e Beta.

No Pós- Palacial (período MR IB - MR III, 1480 a 1070 a.C.) ocorre a destruição do sítio, atribuída à erupção do vulcão da ilha de Tera. O MR IB é a fase na qual esta 
destruição teria se dado, cobrindo todo o sítio com evidências de incêndios, com exceção da casa Épsilon, a única onde há vestígios de uso no MR II. Mais tarde, uma nova destruição no MR IIIB provocou o abandono do sítio. 


\section{Características da Arquitetura Minóica}

De um modo geral, a arquitetura minóica é dotada de uma grande gama de características próprias, presentes tanto nas menores residências (espaço privado) quanto nos seus edifícios monumentais (espaço público). Van Effenterre acredita que o alinhamento quase ortogonal não é casual (EFFENTERRE, 1980, p.289), pois o desenho de suas edificações é vertical, enquanto Graham ressalta que a planta é simetricamente planejada (GRAHAM, 1962, p.236)

Em uma primeira observação as plantas das construções minóicas parecem ser confusas, sem harmonia e em espaços aglomerados. No entanto, olhando-se mais atentamente, é possível identificar uma série de características que delineiam um padrão na arquitetura. Existem unidades repetitivas que mostram uma freqüência de composição de vários elementos básicos em todas as construções da ilha. Desse modo, se configura uma arquitetura organizada em uma série de dispositivos espaciais particulares que na sua somatória fazem a definição dos espaços públicos e privados. Dessa maneira, assinalou Allegrette “... na arquitetura minóica existem padrões visíveis de elaboração do espaço construído" (ALLEGRETTE, 1997, p.6). Pelo menos são reconhecíveis tais padrões em se tratando de projetos que envolvem o uso de especialistas, nos edifícios não vernaculares, dadas as suas dimensões e técnicas empregadas (ALLEGRETTE, 1997, p.6). Enquanto a arquitetura vernacular tem como características edifícios construídos por não especialistas, usaram materiais disponíveis da região, contendo técnicas e tradições locais. Para Palyvou a arquitetura vernacular é o resultado de uma memória coletiva de uma sociedade sem a necessidade de especialistas (citado por DRIESSEN, 1990, p.6). 
O que podemos verificar da arquitetura dos palácios são suas múltiplas funções e o fato de existir um padrão de organização, distribuição técnica, layout, engenharia e composição dos materiais de construção para todos os edifícios, sem exceção. Era muito provável que a arquitetura preenchesse certos requisitos culturais da população em que nela vivia. Ou seja, a arquitetura é uma expressão material de traços culturais dos minóicos, tanto voluntários como involuntários. Certamente os construtores na Creta minóica possuíam princípio formal de equilíbrio e simetria, entre outras qualidades (GRAHAM, 1962). Analisando por esse aspecto é muito provável que a civilização minóica possuísse preceptivas artísticas, assim como na arte de edificar, estabeleceram critérios e dessa maneira se diferenciou seguindo um conjunto de valores e noções próprios (DRIESSEN, 1988-89, p.323), adiquirido uma identidade particular.
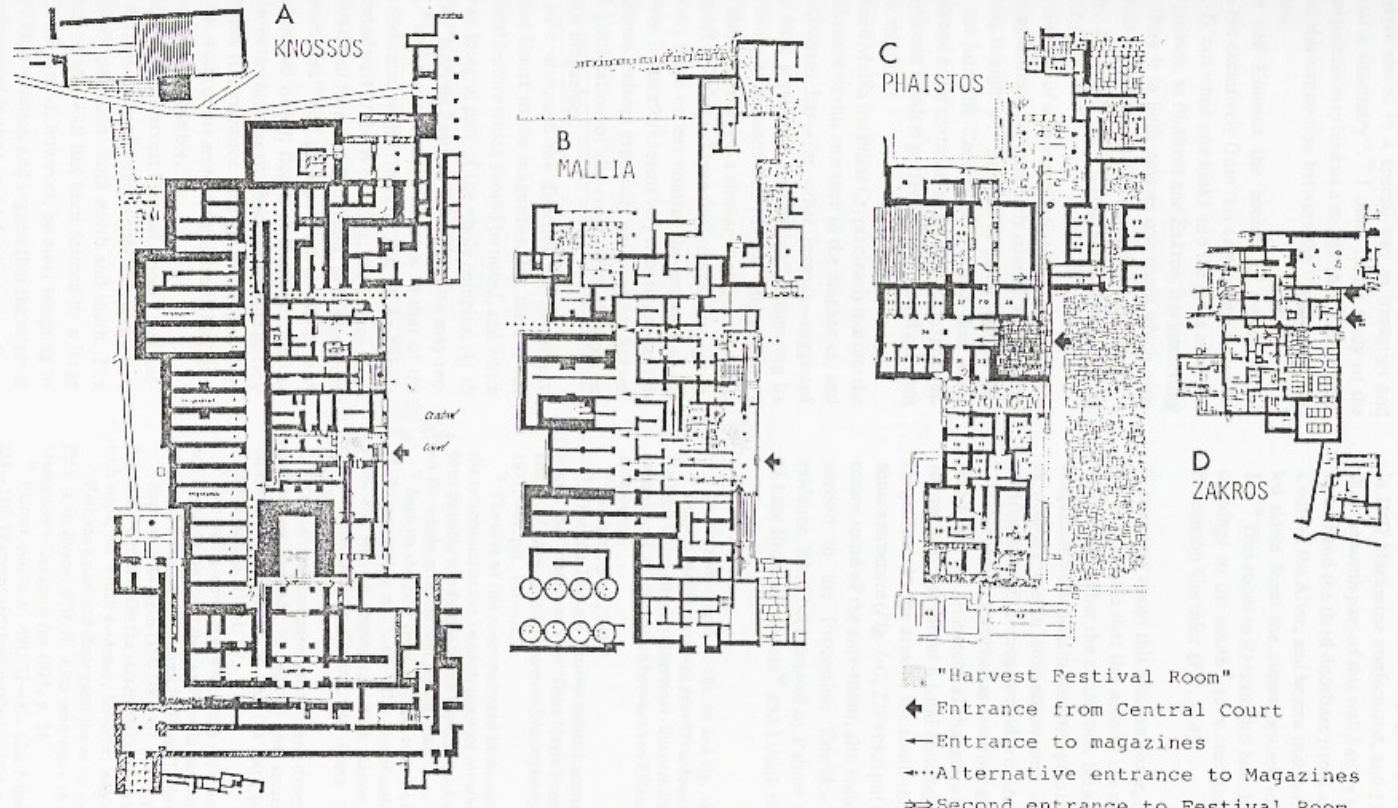

Fig. 4: Semelhança de um "quebra-cabeça"; contudo Hallager aponta nessa imagem somente a ala oeste dos palácios de Cnossos, Mália, Festos e Zacro, mostrando a orientação do pátio central e padrões de salas na mesma ala (HALLAGER, 1987, p.174). 
As plantas das construções minóicas mostram complexos similares, muitas vezes assemelhando-se a um quebra-cabeça de salas de vários tamanhos, corredores, poços de luz, pátios e poços de escadarias (PREZIOSI, 1983, p.4). A fachada exterior das estruturas palaciais não era plana. Graham comenta que a irregularidade no espaço horizontal da fachada era compensada no sentido vertical (GRAHAM, 1962, p. 239), mas ao mesmo tempo era altamente articulada dentro de recessos e projeções alternados (PREZIOSI, 1983, p.5). Dessa maneira, Graham acredita que o princípio da arquitetura minóica é mais funcional do que meramente estético (GRAHAM, 1962, p. 240). É uma integração com o fora e o dentro (questão visual, aproveitamento do espaço e conforto) usando portas duplas, terraços, pátios, poços de luz, polythyron (esta unidade consiste em uma área quadrangular lajeada delimitada por "paredes de ar" e com um pórtico colunado aberto para um poço de iluminação, que faz parte do dispositivo Minoan Hall).

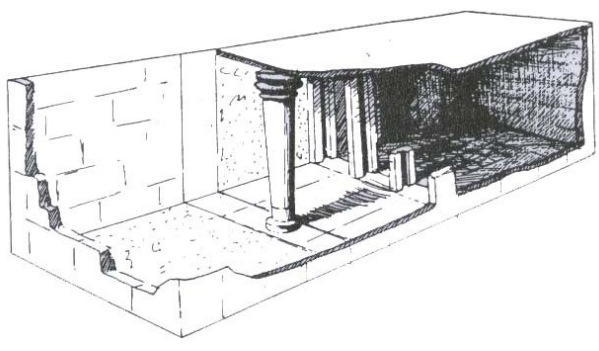

Fig. 6: Uma reconstituição do Minoan Hall (DRIESSEN, 1982, p. 28).

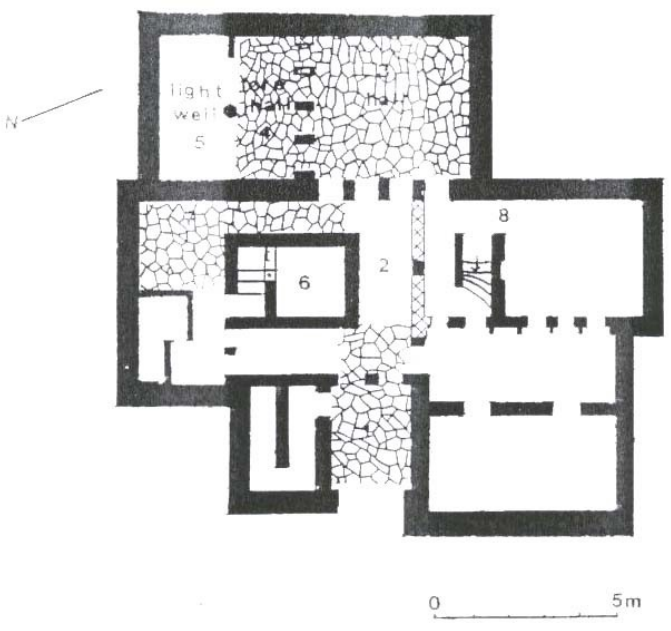

Fig. 5: Casa Delta Alfa, Mália. Minoan Hall sala 5 (DRIESSEN, 1982, p. 49). 
Uma outra interpretação dos aspectos das construções minóicas pode ser devido ao uso de um sistema anti-sísmico para reduzir o risco de maiores danos nas construções, pois a ilha está situada numa zona muito instável da bacia mediterrânica e exposta a freqüentes tremores de terra (HOOD, 1971, p.23). Baseados nas observações levantadas por Driessen², as salas, paredes, fachadas, poços de luz etc, podem também fazer parte desse sistema. O autor aponta uma grande variedade de princípios usados pelos minóicos em suas construções, como: número reduzido de janelas nas fachadas principalmente nos andares térreos, e quase sempre de pequenas dimensões; grande número de paredes; criando diversos espaços de dimensões restritas que diminui o peso estrutural; o próprio polythyron, eficiente sistema de paredes/portas/corredor que cria espaços maiores sem enfraquecer a estrutura; telhados construídos com materiais leves; blocos de casas geminadas; frisos externos; vigas horizontais no alto das paredes; arquitetura sem balcões; paredes finas nos pavimentos superiores e localizadas diretamente sobre as paredes do pavimento inferior e fachadas irregulares que resistem melhor ao choque de várias direções. Este caso pode estar ligado também às fundações, as quais não eram profundas, com as paredes construídas acima de uma base de cascalho para permitir o movimento do edifício, deixando-o mais flexível, caso a superfície da terra se mexesse. Driessen acredita que essas técnicas de resistência a terremotos foram desenvolvidas gradualmente pelos construtores durante o período protopalacial (DRIESSEN, 1987, p. 171-178).

2 -DRIESSEN, Earthquake-Resistant construction and Wrath of the "Earth-Shaker", JSAH, 1987, p. 171-178. 


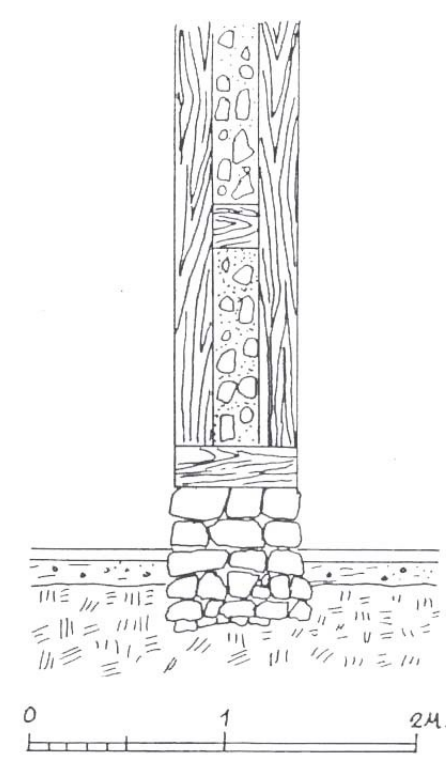

Fig. 8: Fundação, Tilissos (SHAW, 1973, p. 143).

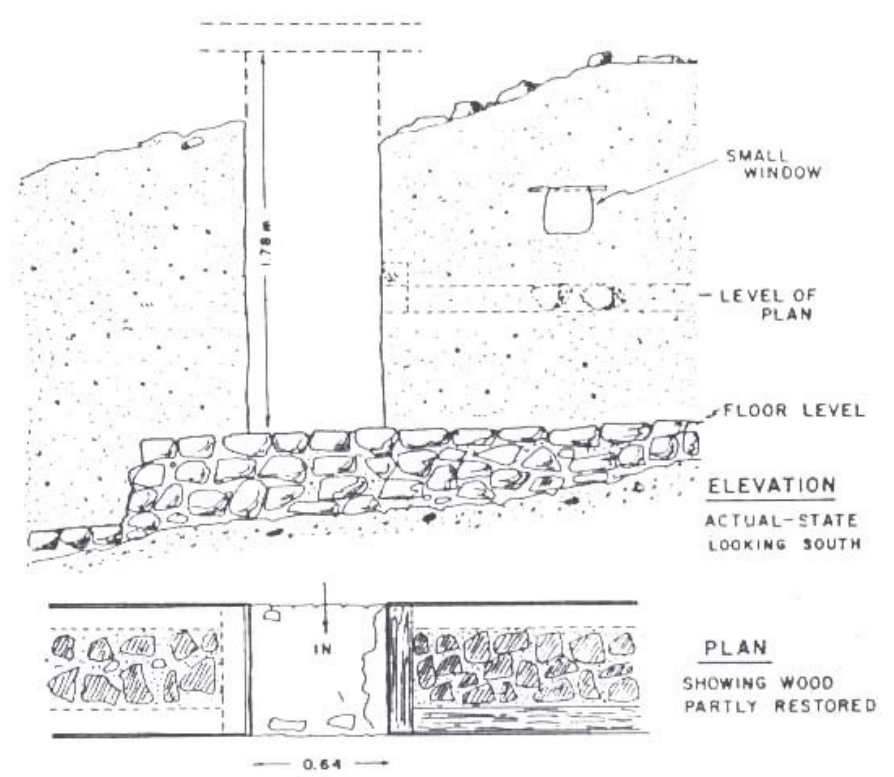

Fig. 7: Fundação, Vasiliki (SHAW, 1973, p. 77).

Apesar do intercâmbio comercial e cultural entre Creta e Anatólia, Egito, e regiões circundantes do Egeu, o desenvolvimento da arquitetura minóica é encarado por muitos autores como local. Watrous deixa claro que o desenvolvimento das construções de Creta é próprio da região. Pois, ele mesmo declara que "esse estabelecimento contém muita particularidade e é provável que as construções fossem essencialmente planejadas e desenvolvidas por arquitetos nativos respondendo às necessidades e condições locais" (WATROUS, 1987, p.65). Como vimos no desenvolvimento desse conjunto de dispositivos anti-sísmicos apontados anteriormente, que correspondem a necessidades específicas dessa região. Opinião compartilhada também por Warren que analisa a progressão de assentamento da ilha de Creta através dos aspectos econômicos, sociais e arquitetônicos desde o período pré-palacial até o neopalacial. Declara também que "durante toda a fase de desenvolvimento (da história arquitetônica minóica), não há evidências de invasores estrangeiros; o que se pode constatar é a intensificação e elaboração dos estilos nativos" (WARREN, 1998). Esta opinião é compartilhada também por Driessen (1988-89, p. 3-23). 
Agora partindo para uma outra discusão, uma análise essencial que é o objetivo da pesquisa, trata-se da tridimensionalidade dos edifícios que por sua vez, pela nossa imagem atual das construções remanecentes, é na maioria das vezes exclusivamente horizontal. Hoje podemos observar ruínas das edificações na ilha de Creta com paredes de, na maioria, um metro de altura no máximo. Em alguns casos veremos as restaurações feitas desde as primeiras pesquisas realizadas por Sir Arthur Evans, até os nossos dias. É através das plantas baseadas nesses vestígios que são realizadas observações e hipóteses da sua estrutura completa.

Para isso, existem três maneiras de imaginar como os edifícios minóicos podem ter sido ponderando vários fragmentos de evidência comparativa, entre as quais:

- A disposição estrutural das plantas;

- As evidências tridimensionais das escavações da ilha de Tera ${ }^{3}$;

- Evidências iconográficas da arte minóica quanto à aparência da típica construção e escopo urbano (PREZIOSI, 1983, p.4). (figs. 13-16 e 31)

Apesar da imagem exclusivamente horizontal, as construções minóicas na sua maioria eram dispostas com grande cuidado e freqüentemente com uma notável precisão, e esse grau de atenção era dado à realização de um projeto, tanto nas construções públicas quanto nas privadas. Preziosi comenta em seu estudo de uma organização formativa modular dos desenhos das construções minóicas, que essa complexidade do arranjo da planta não é resultado de adição aglutinada de 'space-cells" entre elas durante períodos de tempo, como

3. Debaixo do solo vulcânico escavado da ilha de Tera, foi evidenciada, em 1967 pelo arqueólogo grego Spyridon Marinatos, parte de uma cidade minóica denominada Acrotiri. Não mais que duas dúzias de exemplos podem ser citados das paredes estruturais que mantêm-se a uma altura acima de um metro. Essas edificações pertencem ao período neopalacial, o qual o pesquisador fez uma possível conexão entre a erupção de Tera e o colapso da civilização minóica.

4. 'Space-cells' são elementos mínimos de composição arquitetônica, exemplo o Minoan Hall. 
uma vez foi pensado, mas é resultado intencional do desenho e construção inicial (PREZIOSI,1983, p.6).

Assim como Preziosi, pesquisadores têm usado diversas terminologias desde o início das pesquisas. Primeiramente Evans introduz o termo insulae, para designar núcleos construtivos ao redor dos quais se formaria o palácio. Os termos do estudo de classificação são tentativas de qualificar e identificar as diversas partes do edifício, inicialmente por analogia com as estruturas micênicas ou por atribuições pelo seu conteúdo. Desde Evans alguns termos ainda são usados. Graham, em uma outra interpretação, expôs termos como depósitos, sala de cultos, salão de recepção, oficinas, etc (GRAHAM, 1962, 84-142). Ele não pretendia efetuar uma categorização das estruturas arquitetônicas existentes, mas identificar regularidades, padrões e princípios e expor hipóteses relevantes às origens e natureza dos espaços que compunham as diversas estruturas (ALLEGRETTE, 1991, p.18).

Em Mália, Chapouthier e Charbonneaux substituem o termo insulae por ilhotas e quadras, o que parcialmente se explica pela caracterização do princípio de ortogonalidade da arquitetura minóica e pelo estudo de outras construções da cidade, composta por casas agrupadas em conjuntos denominados quadras, cada qual reunindo de duas até seis casas, como são os casos de Delta, Kapa, Zeta e Mu (ALLEGRETTE, 1991, p.15).

Ao lado disso, Van Effenterre ${ }^{5}$ introduziu a noção de bloco, termo que designa a comunicação vertical dos aposentos, quase sempre através de escadas, ligando aqueles do piso térreo aos do pavimento superior e podendo, dessa maneira, ligar duas quadras sem comunicação do piso térreo. Tal noção é importante para a pesquisa, pois é onde nos apoiaremos para a visão das construções tridimencionalmente, não somente as suas plantas, mas também no seu volume vertical. Foi a primeira tentativa formal de estabelecer a noção de

\section{EFFENTERRE, 1980, 2v. Le Palais de Mallia et la Cité Minoenne.}


volumes nos edifícios.

Para poder entender e explorar mais a natureza arquitetônica das edificações minóicas apresentaremos a seguir: a)os aspectos da organização espacial das construções privadas e públicas; b) estudos sobre os pavimentos superiores; c) os materiais e técnicas da construção; $e$ d) as técnicas construtivas das escadas das construções minóicas comparando-as com o conhecimento arquitetônico atual. 


\subsection{Organização do Espaço Privado}

Uma das características da planta residencial minóica são as várias maneiras de ir de uma parte da casa para a outra, é freqüente o caso de as salas terem múltiplas entradas, até mesmo as de tamanho modesto. Uma escolha de movimento dentro da estrutura, salas tendem a ser agrupadas dentro de zonas ou conjuntos de funções comuns: locais de vivência, estocagem, espaço de trabalho, etc. Esses agrupamentos que Preziosi descreve como sendo "space-cells" são configurações complexas que, quando vistas como um todo, cada configuração ou agregado de células (unidades) é interligado com a próxima (PREZIOSI, 1983, p 6).

Para a questão da divisão espacial internas das residências, Allegrette define as partes como componentes da habitação para o período palacial (ALLEGRETTE, 1991, p. 26$30)$.

No período protopalacial os componentes mais comuns são: entrada, salas principais da habitação, depósitos de alimentos ou bens, corredores, pátios e terraços.

Nesse mesmo período, mas na sua fase final, MM II, mudanças significativas ocorreram na habitação maliota, como: acréscimo de subsolo à habitação (como por exemplo a sala I4 da Casa Mu A e as salas VI 1 a VI 6 da Casa Mu B da quadra Mu, acessíveis por escadarias, correspondendo a uma sala lustral e depósitos com funções não identificadas, e também no edifício da Cripta Hipostila), espaços abertos incorporados, poços de iluminação, lareiras, escadaria, construção com mais de um piso. Sendo que esse último acréscimo é assinalado em várias habitações, em especial na quadra Mu. Allegrette assinala que "sua aparição pode ser considerada sob o aspecto da urbanização: a elevação de residência 
sugeriria que o aproveitamento do espaço vertical se faz pela necessidade, já que o espaço horizontal necessário estaria restrito pela concentração populacional no núcleo maliota, que implicaria na expansão das áreas habitadas e no aumento da densidade das instalações" (ALLEGRETTE, 1991, p. 28).

Na cidade de Mália para o período protopalacial são identificados os edifícios Delta, Épsilon, e as quadras Teta, Gama, Beta, Alfa e Mu, esta última possui: duas grandes construções residênciais A e B e mais quatro oficinas: a oficina de selos, a oficina de cerâmica, a oficina de fundição e a oficina Sul.

Para as habitações do período neopalacial, com residencias de grande porte, verifica-se uma série de inovações na arquitetura: vestíbulo de entrada (diferente das residências protopalaciais, o acesso a um espaço lajeado coberto que permite a passagem para o corredor principal da residência e em alguns casos para escadaria de acesso ao piso superior, caso da quadra Épsilon), polythyron, sala lustral (plano quadrangular, entrada de ângulo reto, escadaria de acesso e nível inferior ao do solo; esta sala tem sido interpretada tanto como sala de banhos como sala lustral ou mesmo como combinação de ambas - GRAHAM, 1963, p.99), e peças de serviço (cozinhas, depósitos, escritórios, adegas, latrinas, alojamentos para criados e graneleiros). Quadras Zeta, Épsilon, Delta, Kapa Gama.

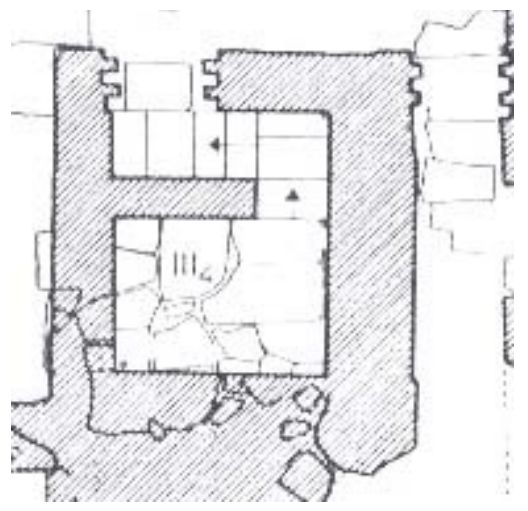

Fig. 9: Sala lustral, quadra III do palácio de Mália ( MALLIA, 1929$35, p l . I V)$. 
As similaridades entre as casas minóicas são mais acentuadas nos detalhes de organização e em relação entre os componentes do que na identidade global das plantas térreas e nas configurações geométricas dos edifícios. Mesmo nas cidades minóicas, acondicionadas compactamente as configurações das casas não são 'enfileiradas' - em outras palavras, como

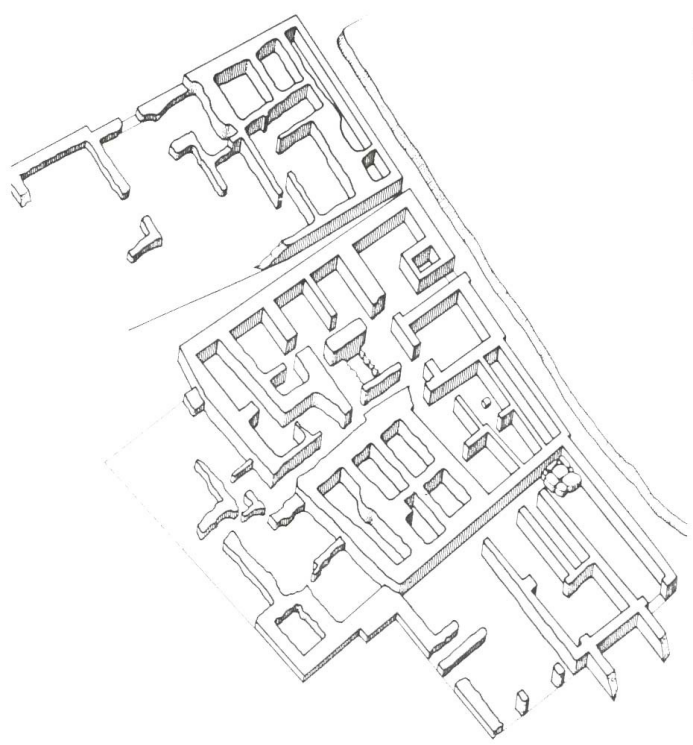

Fig. 10: Quadra Delta (PREZIOSI, 1983, fig. 14). estruturas idênticas alinhadas juntas ao longo da rua - mas precisamente tendem a ser notavelmente diferente no arranjo interno. Necessariamente uma característica do resultado de adicionamento aos poucos dentro de um tecido urbano, como é ilustrado na planta da Quadra Delta, Mália (PREZIOSI, 1983, p.7).

As casas ao longo da rua parecem que foram construídas ao mesmo tempo, como indicado pela articulação da fachada uniforme. Entretanto, podemos averiguar principalmente na planta da casa Zeta Beta, que houve uma reestruturação urbana nas ruas das quadras residenciais. Muito provável que algumas das casas que possuem um histórico - desde assentamentos pré-palaciais ${ }^{6}$ já existiam antes de uma urbanização. Talvez seja por causa disso também que cada casa revela diferentes arranjos internos. Contudo, uma boa parte do espaço é voltada para as funções complementares da circulação entre os agrupamentos de

6. Estabelecimento de povoados agrícolas que já possuíam uma vida comunitária com uma economia agrícola baseada em cereais, azeitonas, vinhedos e rebanhos, que ajudaram a criar as condições sociais necessárias para o surgimento dos palácios (WARREN,1998). 
salas e suas separações. Zonas funcionais, em outras palavras, não abrem diretamente entre elas, mas são separadas por corredores e as distâncias que eles oferecem (PREZIOSI, 1983, p.7).

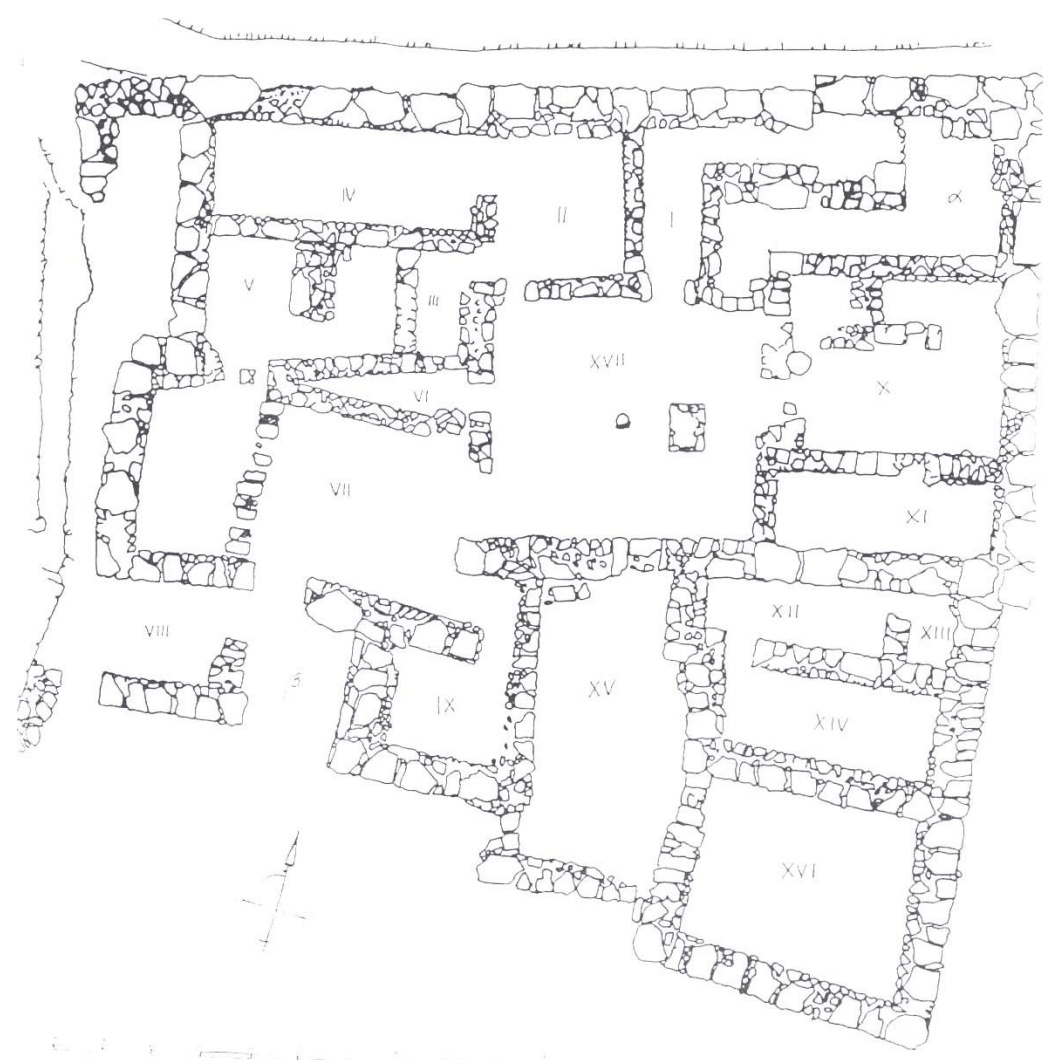

Fig. 11: Casa Zeta Beta (DESHAYES e DESSENNE, 1948-54, pl. II).

É através dos arranjos internos que o pesquisador Sanders (1990) analisa a importância da Arqueologia na mútua interação entre as relações das convenções comportamentais e o meio construído e mais preciso no espaço privado, pois os marcadores dos territórios regulam comportamentos específicos. Quanto mais público o território é, maior a necessidade de sinais. Quanto mais privado, mais a convenção cultural é usada. E quanto mais permanente é a ocupação, mais elaborados são os sistemas de sinais. 
Com um outro olhar mais amplo, a cidade de Mália no seu contexto urbano consiste em "vestígios" de casas em volta do palácio, como as quadras Delta, que ficam a oeste do palácio, e Zeta, a leste (GRAHAM, 1962, p.63). Essa característica se destaca particularmente dentro do conjunto de sítios palaciais e urbanos da Creta minóica, exatamente por ser um caso em que se pode contemplar o desenvolvimento de um núcleo urbano para o núcleo palacial. O que não acontece em outras cidades da Idade do Bronze em Creta (ALLEGRETTE, 1997, p.1).

Dentro desse contexto, a verticalização da cidade está diretamente ligada tanto ao seu crescimento como à sua estética. A imagem da cidade muda de aspecto quando relacionada ao seu crescimento vertical. Existem suposições que nos espaços privados há uma questão do dentro para o fora, onde a possibilidade de espaços abertos nas construções estão direcionadas para os terraços e dessa maneira direcionada para a malha urbana, para o mundo exterior. Enquanto a palacial, a pública é de fora para dentro, tendo ela sua própria malha interna, um mini complexo urbano próprio, como veremos no próximo item. Contudo, a maior contribuição para a restauração dos pavimentos superiores e da recuperação de tridimensionalidade nas construções provém dos restos das escadas. Elas são elementos arquitetônicos fundamentais para tal conexão. 


\subsection{Organização do Espaço Público - Palácio, Cripta, Ágora}

$\mathrm{Na}$ organização estrutural de um único edifício, o palácio, podemos averiguar uma planta similar, até mesmo em seus detalhes e características, como a orientação e o tamanho dos pátios centrais (fig.4), a organização dos depósitos, além de todos estarem situados na costa ou próximos dela, contendo: pátio central, salas de estocagem, silos, áreas de produção (oficinas), arquivos de tabletes inscritos, salas para atividades rituais e salas para funções governamentais, sala lustral, quadras residenciais, poços de luz e terraços, entre outras salas identificadas como sala de trono, de banquete e cozinhas. Há diversas entradas e saídas claramente identificadas, tanto as principais como as secundárias e uma organização de circulação (horizontal e vertical), restritas em algumas partes que demonstram mais privacidade assim como as sem restrições de acesso, mais públicas.

Os palácios constituem estruturas de configuração interna complexa, servindo a múltiplos propósitos, e associados à centralização do poder e da produção artística, econômica, religiosa e tecnológica desta civilização, comparáveis em função e escala aos templos e palácios do Egito e Mesopotâmia (ALLEGRETTE, 1991, p.1). Levando-se em conta que o palácio tinha funções que se estendiam a todos os aspectos da vida da cidade, um estudo sobre a maneira como o palácio operava pode formar a base para uma reconstrução de toda a sociedade minóica (WARREN, 1998).

Na configuração interna dos palácios observamos divisões dos conjuntos de salas distintas dentro de um único edifício e suas múltiplas funções, ou como Pelon cita "um edifício de funções polivalente" (PELON, 2001, p. 111 - 120). Allegrette descreve essas configurações baseando-se na evolução dos estudos arqueológicos da ilha de Creta, e dessa maneira: "pesquisadores tiveram o mérito de elaborar o princípio que guiaria o trabalho de 
descrição e análise do palácio e das estruturas do sítio”. A identificação do planejamento, que vários pesquisadores comentam nas construções palaciais, se dá também através da organização de suas articulações internas ${ }^{7}$, que possui a função de comunicar espaços sem contato imediato e, por outro lado, ressaltar o isolamento de outros espaços (ALLEGRETTE, 1991, p.91). Tal princípio se baseia na premissa de existência de uma ordem na disposição dos aposentos onde haveria uma dependência de uns em relação a outros, isolamento através de paredes mais espessas entre os aposentos distintos, passagens facilitadas entre alguns e separação entre outros; essas características identificaram quadras com fisionomia própria e com uma destinação particular, resultando no palácio como uma justaposição de insulae independentes (ALLEGRETTE, 1991, p. 14; CHAPOUTHIER e CHARBONNEAUX, 1928, p.4). Contudo, já que o desenho de suas edificações é vertical, as escadas são fundamentais para o complemento da circulação interna. Assim ao comentar sobre a compensação vertical não podemos deixar de mencionar as escadas, o elemento que liga e faz essa compensação.

As pesquisas de Evans, o primeiro a mencionar as funções palaciais, apontam que o palácio, tanto quanto a residência de um monarca, era também o centro de organização política, econômica, religiosa e tecnológica. Porém essa interpretação se aplica às construções do período neopalacial. Para o período protopalacial essa situação não está tão definida. Existem também edificações públicas: a Cripta Hipostila e a Ágora. Esta última seria um local que teria finalidades como jogos, festivais, espetáculos, iniciações ou comércio, sugere Allegrette (1997, p.181). Já para a Cripta Hipostila, Allegrette ressalta que o empreendimento não é habitacional pois não corresponde a nenhum paralelo existente na arquitetura minóica” (ALLEGRETTE, 1997, p.182). Sua hipótese é de uma função cerimonial, à qual não associa

7- Elemento de circulação que define e controla a movimentação dos indivíduos tanto na entrada e saída do edifício quanto no seu movimento interior, entre as quadras e dentro destas, tendo por vezes o papel identificador da condição de determinada área do palácio, assim como a combinação das portas e escadarias em um mesmo ponto. 
uma conotação política ou religiosa pela ausência de elementos que sustentem tais caracterizações. Sua finalidade permanece incógnita (ALLEGRETTE, 1997, p.198).

Van Effenterre, baseando-se nos artigos do colóquio The Function of Minoan Palaces $^{8}$, aponta seis diferentes funções dos palácios: a monumentalidade ${ }^{9}$, quanto ao seu tamanho, materiais e técnicas empregadas por especialistas para a sua constução e decoração, sendo o pátio central uma característica determinante dentro da planta do conjunto que permite uma fachada interna e dentro dessa categoria; a convivialidade, onde o palácio possui alguns espaços para residir pessoas importantes; o sagrado, lugares destinados a rituais cerimoniais, como festivais, jogos, procissão de oferendas, e outros onde talvez eram destinados para culto religioso, diferente de templos; a administração, apesar de ainda não terem decifrado o Linear A, sabe-se que os documentos encontrados nos palácios eram de registros contábeis, o que não se sabe ainda também é a extensão dessa administração; a economia centralizada, como centro de produção, comercial e capacidade considerável de estocagem, armazéns, silos, enormes jarros, concentrados no palácio e vital para a comunidade onde ele é o responsável; e o último e único aspecto que não está claramente identificado, o educacional, formadores de técnicos e escribas, que Van Effenterre acredita ser uma das funções do palácio (EFFENTERRE, 1987, p. 173-185).

Em todos os grandes palácios da Creta minóica, observamos que existe um edifício coerente. Entretanto, o palácio de Mália não foi erguido de uma só vez, sendo apenas o estágio final de construção, o neopalacial (1700 - 1450 a.C.) independente daquele do período anterior. Contudo, o primeiro palácio foi erguido por volta de 1900 a.C. e o segundo cerca de 1700 a.C. (ALLEGRETTE, 1991, p.14; WARREN, 1998).

8 HAGG, Robin \& MARINATOS, Nanno (Eds.) - The Functions of the Minoan Palaces. Proceedings of the Fourth International Symposium at the Swedish Institute in Athens 1984. Stockholm, Paul Astrom, 1987.

9 As características de monumentalidade podem ser encontradas na Cripta Hipostila e na Ágora. Opinião apoiada também por Driessen (1989-1990, p.8) 


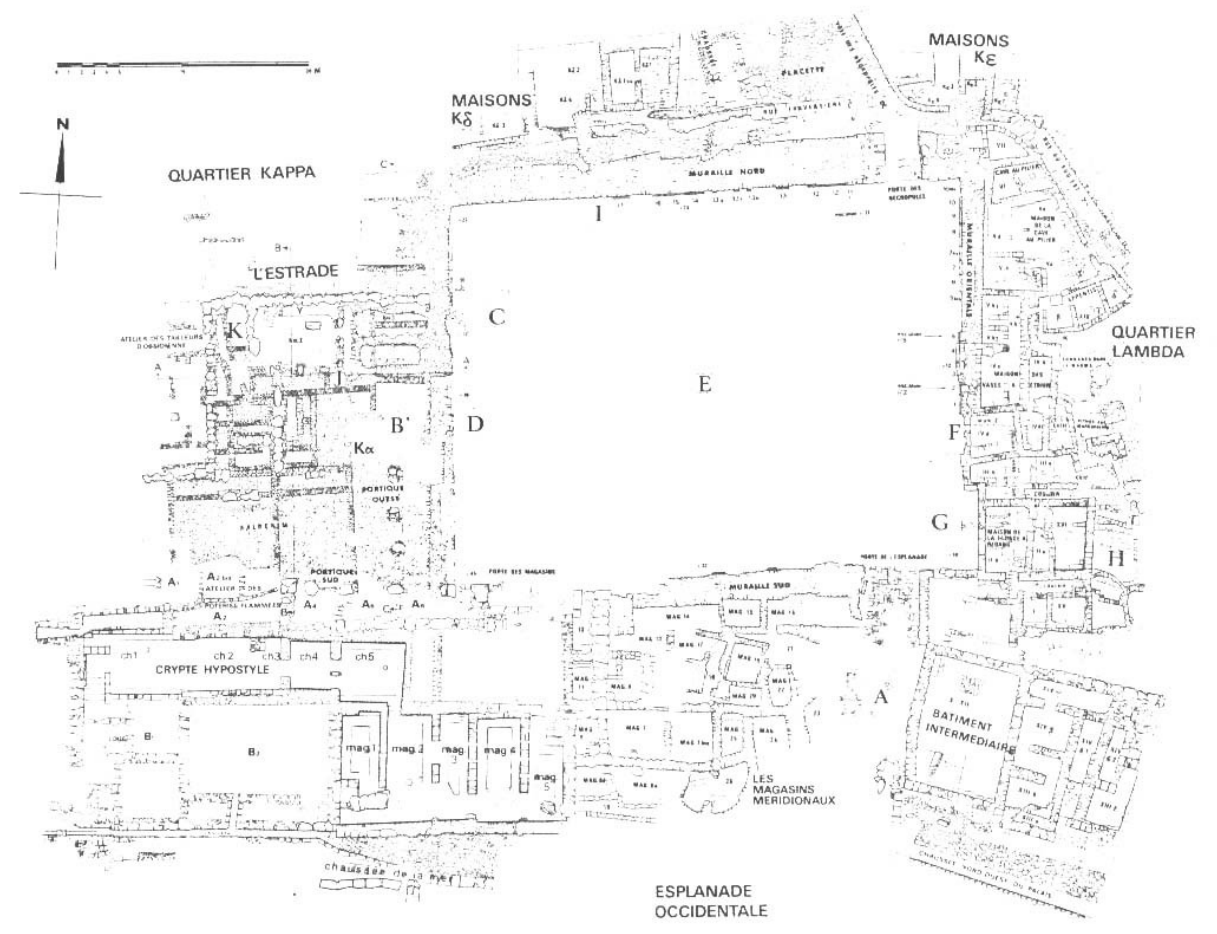

Fig. 12: Planta de localização da Cripta Hipostila e da Ágora (EFFENTERRE, 1962, fig. 265).

No palácio de Mália existe uma irregularidade em sua fachada, contudo isso também é uma característica dos palácios cretenses, como veremos à frente. Graham assim como Chapouthier e Demargne ${ }^{10}$, observam que o interesse não seria o visual de fora, mas uma preocupação interna já que "pela planta pode-se dizer que o edifício foi planejado em unidades radiais a partir do pátio central” (GRAHAM, 1962, p.237) que poderia ser tão importante como o edifício a sua volta (PALYVOU, 2001, p.167-177). E desse modo, existia mais praticidade do que estética (GRAHAM, 1992, p.238), essa praticidade seria de função de ponto de foco (PALYVOU, 2001).

Para isso mostraremos as observações construídas por pesquisadores ao longo do trabalho de identificação dos edifícios tanto públicos como privados da civilização

10 Chapouthier, F. e DeMARGne, P. - Palais III: Troisiéme Rapport, Exploration du Palais. Mallia, Et. Crét. VI: Fouilles Exécutées à Mallia. Librairie Orientaliste Paul Geuthner, Paris, 1942. 
minóica na tentativa de estabelecer a noção de volumes e tridimensionalidade. Uma outra característica dos palácios minóicos são seus pavimentos superiores, que poderiam chegar a até quatro andares. Apontaremos no próximo item suposições e discussões sobre esse fenômeno e seus indícios. 

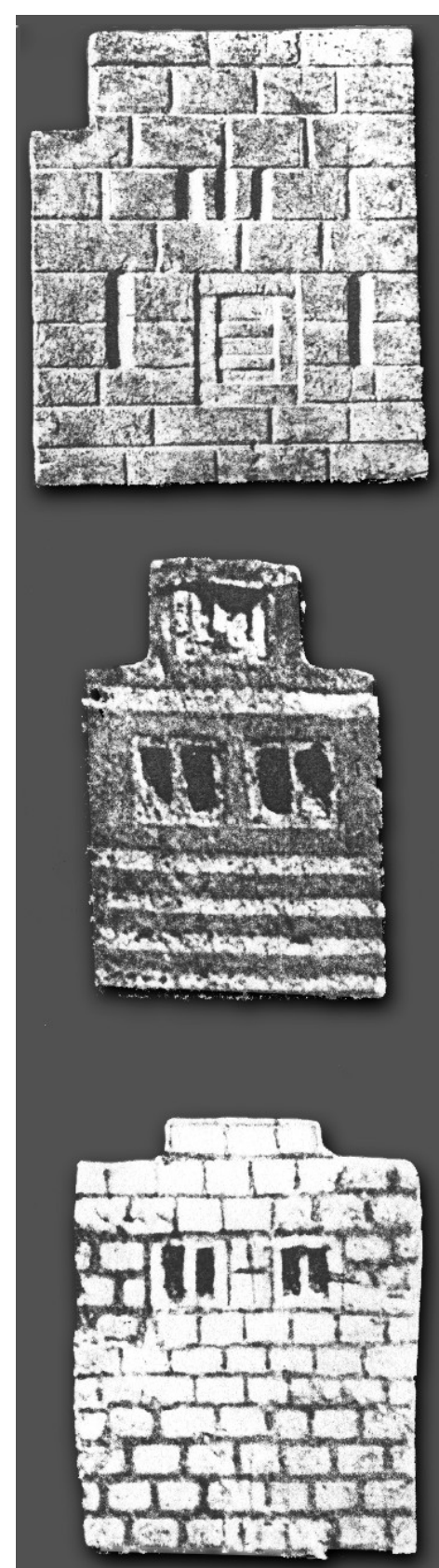

Genges

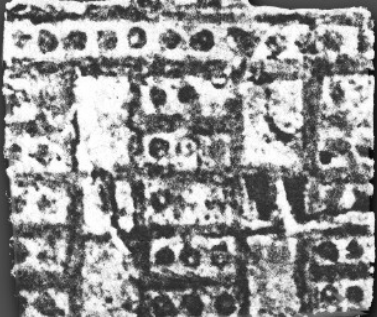

$x+4 \times 260$

Fig. 13: Plaquetas de fainça

\subsection{Pavimentos Superiores}

Apesar da nossa imagem atual da arquitetura maliota ser exclusivamente horizontal, ela possui indícios de sua construção vertical, tanto nas habitações como no palácio. No caso das residências varia de dois até três andares, como é o caso da quadra Mu. Já para o palácio o número varia consideravelmente, por suas razões práticas, em diferentes quadras (EFFENTERRE, 1980, p.321).

Os indícios mais antigos que temos de edifícios com a probabilidade de existir pavimento superior na ilha de Creta é a casa Vermelha de Zois, no sítio de Vasiliki. Acredita-se que essa construção possuía estrutura para o segundo pavimento datado do MA IIB (WATROUS, 1998, p.708), época marcada pelo período de expansão da Era do Bronze em Creta. O número de assentamentos dobra nesse período. As áreas escolhidas foram ao longo da costa e no interior (WATROUS, 1998, p.705-717). Assim como em Mirtos, os construtores simplesmente coletaram pedras soltas no chão ao redor do local para a construção. Shaw menciona que o primeiro pavimento dessas casas foi erguido sobre fortes fundações, como formação rochosa, e para os pavimentos superiores usaram madeira e tijolo. Até mesmo camadas de calcário e seixos rolados eram usadas 
para as paredes e nenhuma rocha talhada foi encontrada tanto em Vasiliki como em Mirtos (SHAW, 1973, p.11).

O final do período MA IIB foi marcado pelo abandono de vários sítios em Creta e traços de destruição pelo fogo foram achados em Vasiliki, Mirtos e Mália (WATROUS, 1998, p.729).

O período posterior, o protopalacial, ocorre quando os maliotas tiveram inicialmente estendido suas construções. Eles só pensariam em construir os edifícios mais altos no começo do MM II, quando certamente uma obstrução no centro da cidade aparece (EFFENTERRE, 1980, p.320). Esses indícios da existência de pavimentos superiores são baseados em quatro tipos de vestígios arquitetônicos:

- as escadas;

- diferente construção e espessura das paredes térreas;

- fragmentos preservados de terracota do teto e do forro do edifício;

- vestígios arquitetônicos tombados e preservados do andar superior nas formas de pavimento de lajes e soleiras (HALLAGER, 1990, p.282).

Uma outra fonte de informação disponível é provida pela descoberta no palácio de Cnossos de pedaços de faiança mostrando como eram as fachadas das casas urbanas. As placas de faianças nos mostram uma porta no nível da rua e duas janelas alinhadas no qual devem ser o segundo e terceiro andar, assim como o modelo de terracota de uma casa minóica de Arcanes. O modelo, descoberto em 1970, mede cerca de $31 \mathrm{~cm}$ x $28 \mathrm{~cm}$, datado MM III, período protopalacial (WATROUS, 1998, p.743), e reproduz com exatidão o tamanho e a disposição dos cômodos e demais elementos arquitetônicos. O Departamento de Arqueologia 
Clássica da Faculdade de Filosofia de Erlangen-Nürnberg, Alemanha, conseguiu fazer uma interessante reconstituição virtual a partir do modelo original. E uma magnífica representação de um selo de impressão estampado em cerâmica encontrado no sítio de Cânia.
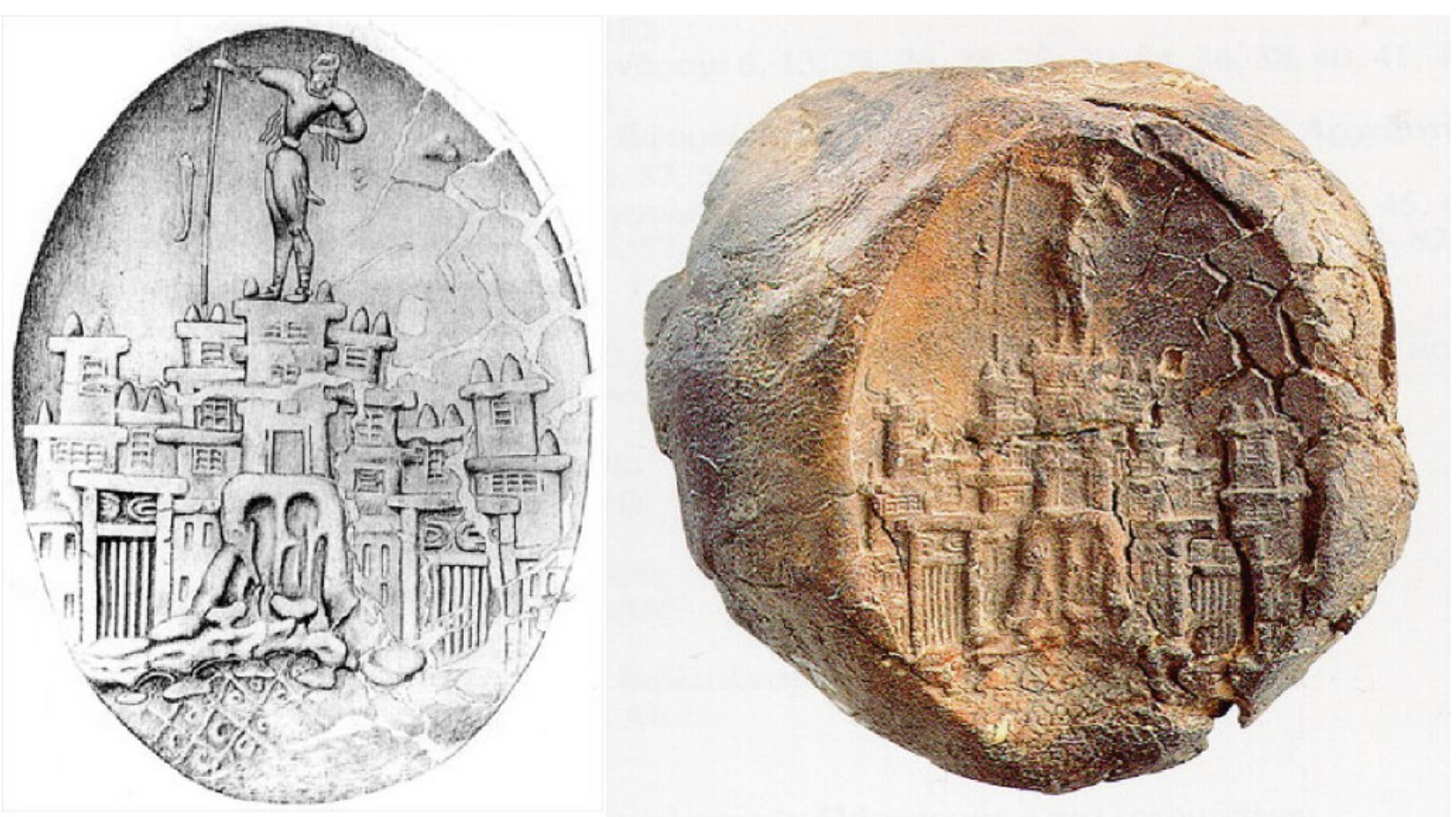

Fig. 14: Estampa de um selo representando um edifício e seus pavimentos superiores (Referência Eletrônica 1 httpccwf.cc.utexas.edu perlmanmythmaster.html).

Também podemos contar com as informações do sítio de Acrotiri, que apesar de se situar na ilha de Tera, as construções são minóicas e contemporâneas às da ilha de Creta. A cidade sofreu com uma erupção vulcânica, por volta de 1500 a.C., do período MR, que, pela alta camada de cinzas vulcânicas e púmice (pedra-pomes), preservou seus edifícios onde ainda existem partes do segundo pavimento. Materiais foram encontrados em abundância, já que os habitantes saíram rapidamente levando talvez somente aquilo que poderiam carregar, deixando evidências sobre suas funções e seus afrescos. Em uma das mais importantes iconografias, o friso de "Flotilha", dentro da sala 5 na casa leste, o tema seria a viagem de uma flotilha de uma cidade para outra, ou uma ilha para outra. Essa imagem é importante para 
mostrar o número de andares que os edifícios possuíam, assim como o uso de seus terraços (DOUMAS, 1983, p. 120).

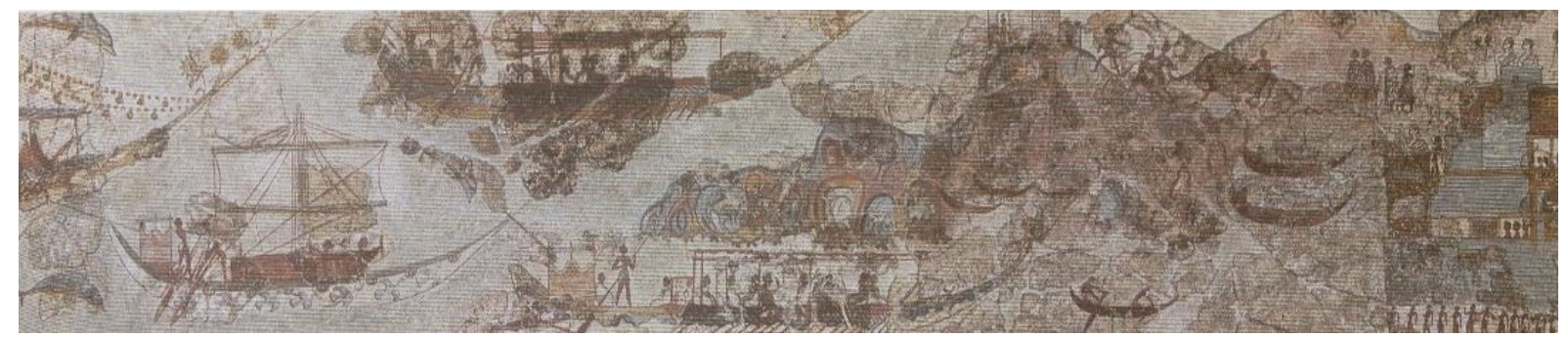

Fig. 15: Afresco, viagem de Flotilha (DOUMAS, 1983, fig. X).

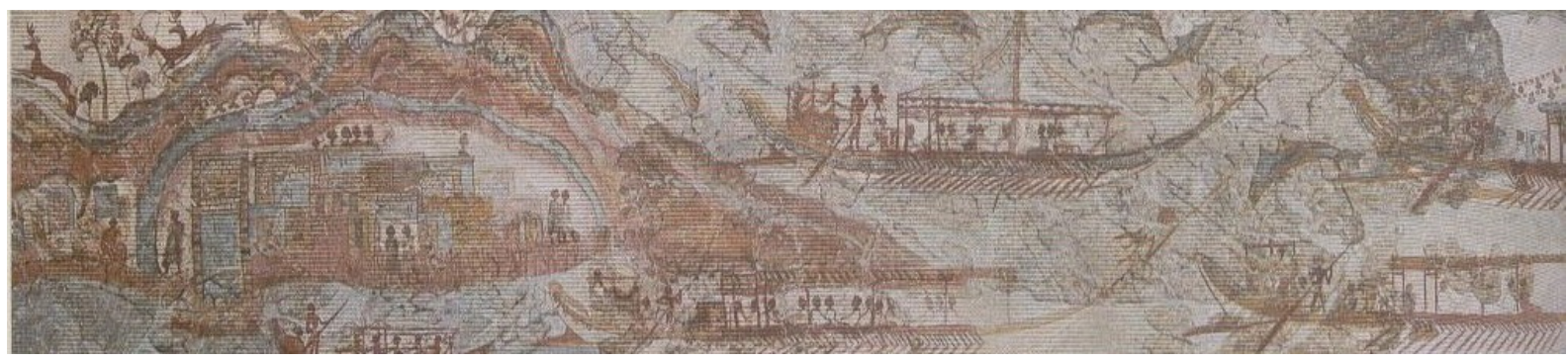

Fig. 16: Continuação Afresco, viagem de Flotilha (DOUMAS, 1983, fig. X).

O material iconográfico é de grande importância para assim verificar as suposições de pesquisadores quanto ao pavimentos superiores. Para Shaw (1973), assim como para Schoep (1994), validam a importância do estudo iconográfico, tanto os modelos tridimensionais como as pinturas, um recurso a mais para o estudo na resconstrução dos restos arquitetônicos. 


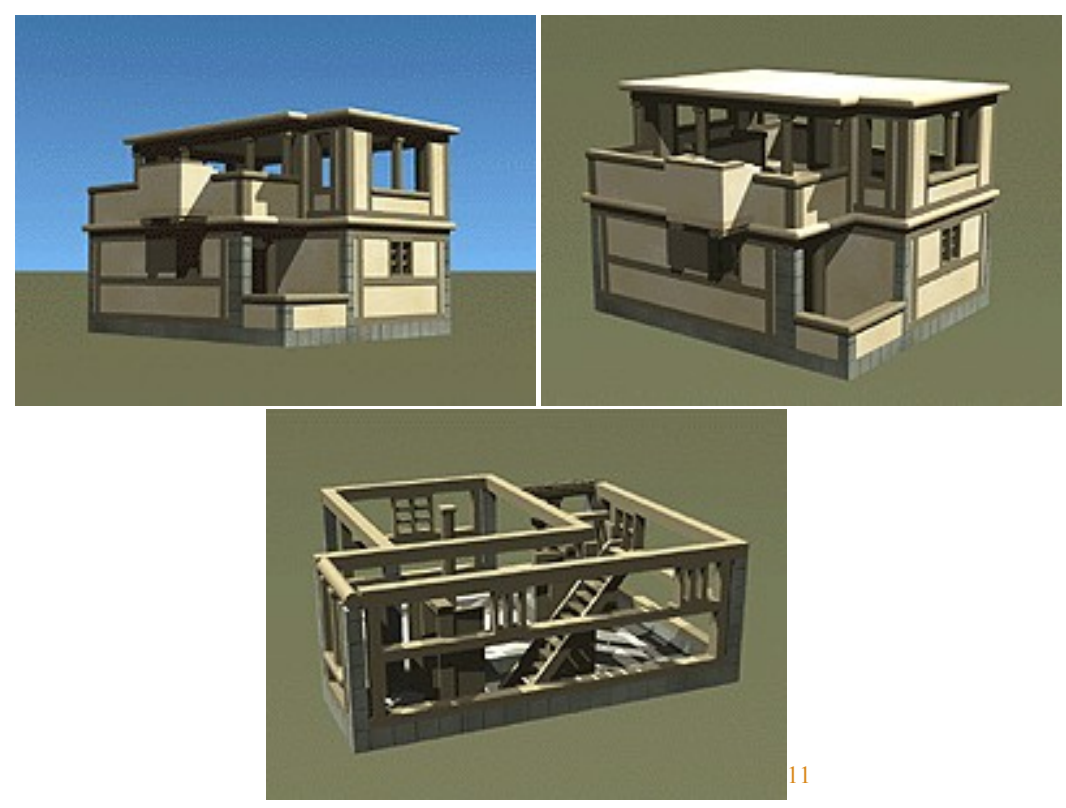

Com base em todos esses indícios, mostraremos sugestões e hipóteses de vários pesquisadores quanto à função dos pavimentos superiores nas construções de sítios na ilha de Creta. Primeiramente, possuímos dois estudos importantes sobre o sítio de Mália, mais precisamente sobre o palácio.

Nos trabalhos de Graham ${ }^{12}$ são oferecidas hipóteses sobre os andares superiores do palácio de Mália baseadas nos sítios de Cnossos e Festos, e nos planos das construções egípcias e mesopotâmicas. Ele acredita que as salas cerimoniais, mais amplas e importantes, ficavam nos pavimentos superiores, seriam as salas para culto religioso e/ou de reuniões, assim como a sala de banquete (GRAHAM, 1962, p.114-129). Graham discute com quase

11- Modelo de Arcanes de vários ângulos, reconstituição virtual. Referência eletrônica 2: http://www.phil.unierlangen.de/ plaltar/ausstellung_html/lectures_html/archanes/archanes1b_shot1.jpg 12- Further Notes on Minoan Palace Architecture: 1. West Magazines and Upper Halls at Knossos and Mallia; 2. Access to, and Use of, Minoan Palace Roofs (1979, AJA 83, p. 49-67) e Palace of Crete, 1962. 
absoluta certeza que as duas escadas, que situam-se ao redor da sala Hipostila, têm a função de levar à sala de banquete, sugerindo que uma delas serviria como escada de serviço, próxima à cozinha no pavimento inferior, e a outra seria de uso social (GRAHAM, 1979, p. 9), se apoiando na forma adotada no palácio de Amarna, Egito. O mesmo aspecto é apresentado também ao norte do pátio central do palácio de Festos: a sala de banquete no pavimento superior conectada pelas escadarias 42 e 43, sendo o piso inferior ocupado por salas de armazenamentos, salas de cultos e a quadra residencial (GRAHAM, 1962, p.38).

Graham também discute a sala de Recepção que seria uma sala de reunião de natureza religiosa, social ou política, acima das quadras I e VIII, tendo como acesso a escadaria do pátio central (1979, p.57-61). Para isso, Graham se baseia também nas paredes espessas que serviriam de contrafortes para o pavimento superior como também relaciona com o palácio de Cnossos.

Quanto a um terceiro pavimento, Graham acredita que serviria como terraços,

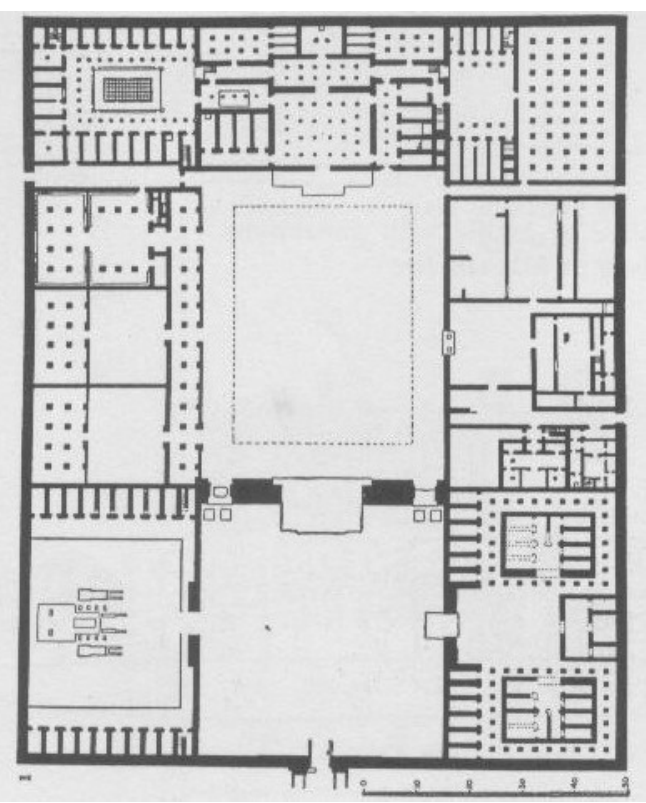

Fig. 17: Setor norte do palácio de Amarna, Egito. Salas com pilares (GRAHAM, 1962, fig. 149).

varandas com parapeito, e dessa maneira ele faz uma interessante suposição do terceiro pavimento acima da sala de banquete, apoiando nos corredores ao norte da sala hipostila, o qual teria uma terceira escada, que levaria ao terceiro pavimento, um terraço coberto com a função de possibilitar apreciação dos acontecimentos no pátio central. Graham mostra uma comparação entre uma reconstrução do palácio de Festos e o modelo de Arcanes $(1979$, p. 6469). E dessa maneira realiza uma reconstrução do palácio de Mália. 


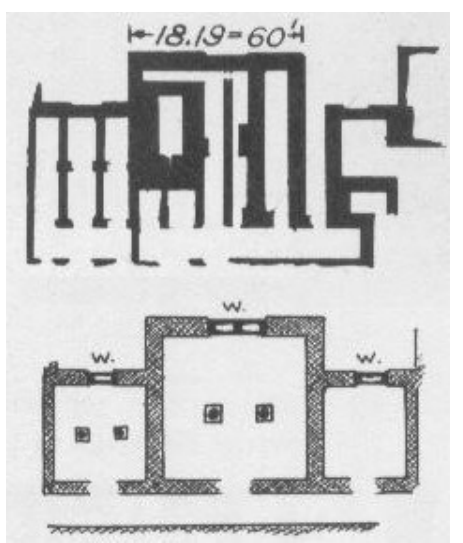

Fig. 18: Palácio de Mália, proposta de Graham do pavimento superior sala de Recepção. Planta térrea, acima, parte das quadras I e VIII. Planta do pavimento superior, abaixo (1962, fig. 8384).

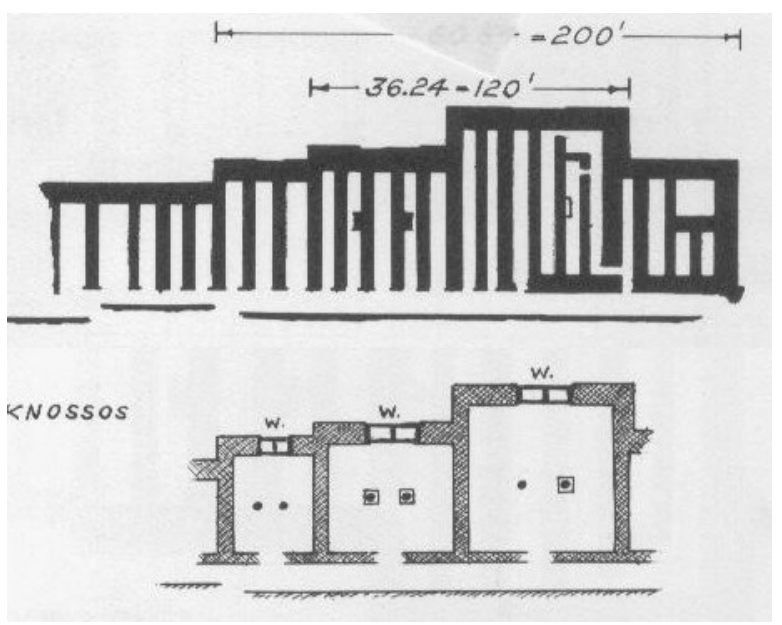

Fig. 19: Palácio de Cnossos, pavimento superior, restauração Evans. Planta térrea, acima, parte das quadras I e VIII. Planta do pavimento superior, abaixo (GRAHAM, 1962, fig. 83 e 84).

Já para Van Effenterre as escadas estreitas no caso das quadras III, XVII ou XIII e XXVII, deviam apenas dar acesso a um andar leve ou a um terraço. Ao contrário daquelas da quadra IX, XXII, IV 7-8 e VI 8, que poderiam servir para apartamentos importantes no pavimento superior, concordando com a análise de Graham. Contudo, em seu trabalho ele realiza rapidamente pelas restituições axonométricas do palácio (EFFENTERRE, 1980, p. 322-324). De acordo com o número de andares o palácio divide-se em blocos: o bloco plano (o pavimento térreo), o bloco baixo (o segundo pavimento), e o bloco elevado (o terceiro pavimento), para indicar volumes correspondentes. Van Effenterre acredita que mesmo nas divisões das quadras do pavimento térreo, o bloco superior utiliza uma outra dimensão, conectando diversas quadras. Como é o caso da vizinhança da sala hipostila sob o salão do banquete, onde este bloco reagrupa-se em três quadras, a IX, XXI e a XXII (e os bastiões C eD). 


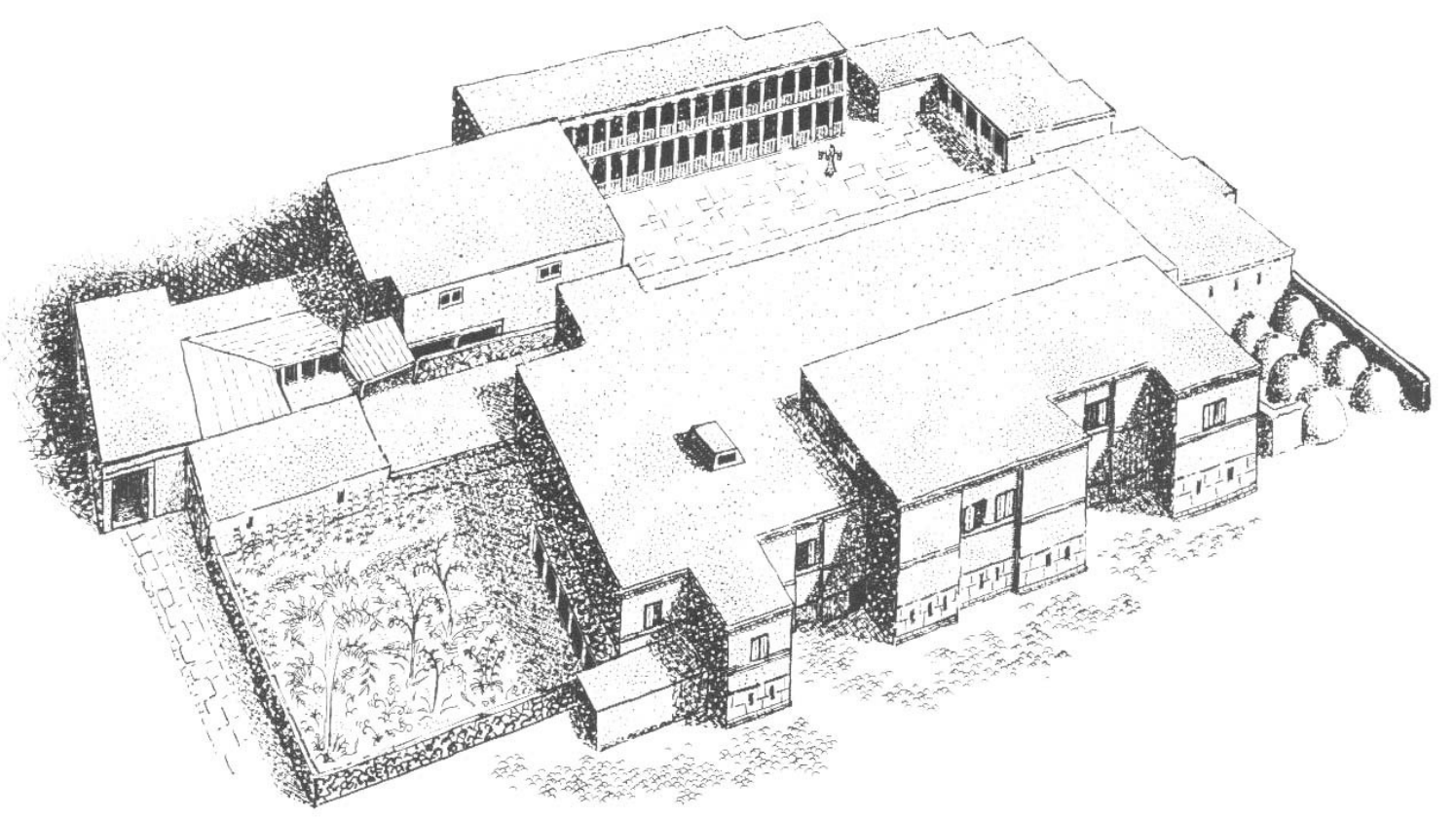

Fig. 20: Perspectiva tridimensional do palácio de Mália, segundo Graham (1962, fig. 58)

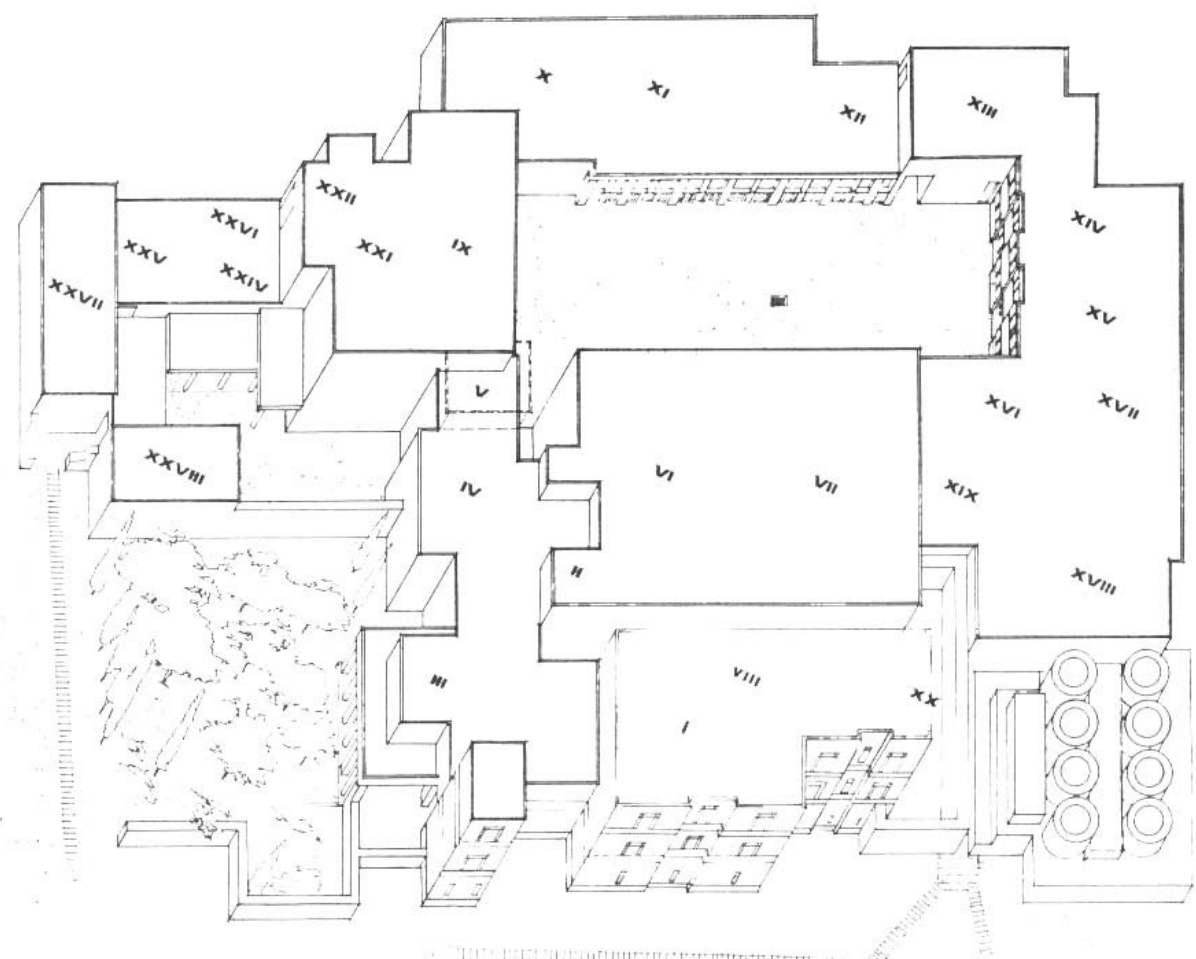

Fig. 21: Perspectiva tridimensional do palácio de Mália, segundo Effenterre. (1980, fig. 457) 
Existe também uma maquete que não possui publicação, ela está exposta no sitío de Mália produzida pelo arquiteto Schmid (1996). As alas que possuem somente dois pavimentos são a sul, oeste e parte da norte. O restante da ala norte, onde se localizam as quadras IX, XXI e XXII, teria um terceiro pavimento, um terraço, e na área residencial, quadras III e IV. Na ala leste, possuiria uma quarto pavimento, como um terraço também, acima das quadras VI, VII e VIII. Infelizmente, não possuimos mais dados sobre sua circulação interna proposta nesta maquete.

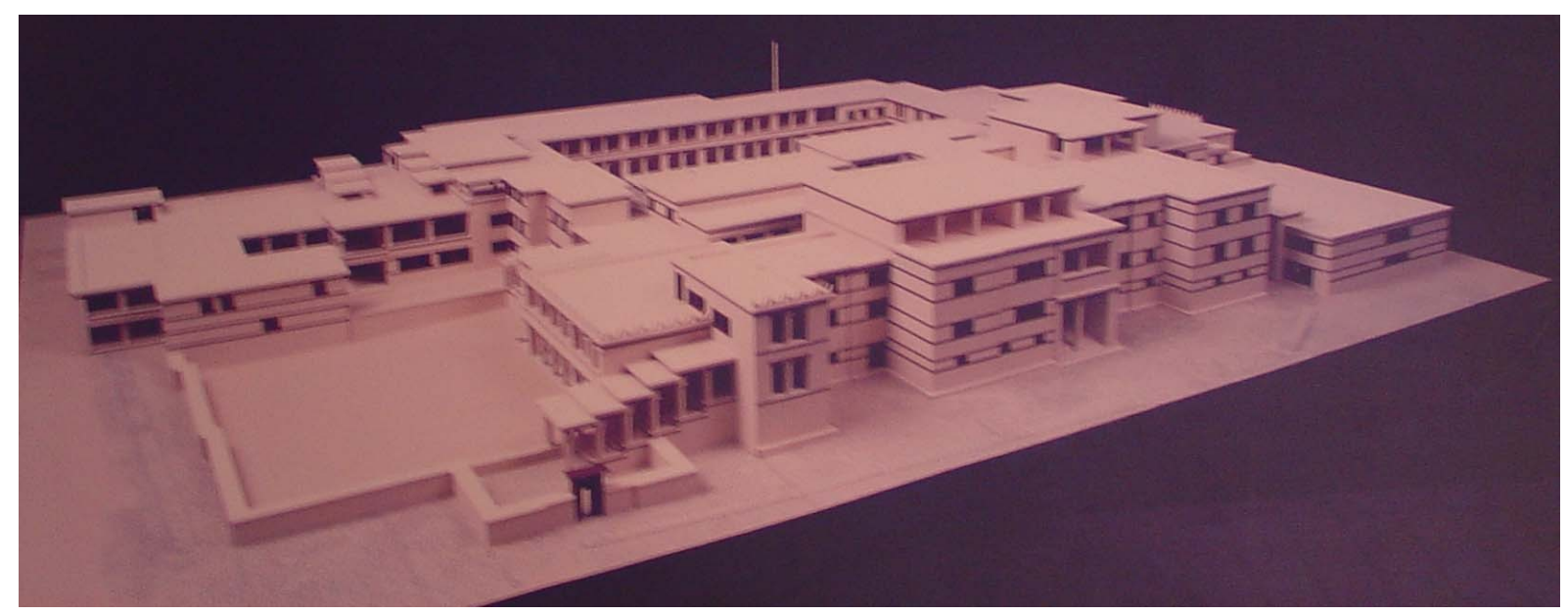

Fig. 22: Maquete do palácio de Mália (SCHMID, 1996).

Para as construções domésticas possuímos o estudo referente aos pavimentos superiores de algumas residências de Acrotiri, onde a pesquisadora Michailidou conclui que os pavimentos inferiores serviriam para estocagem e algumas atividades, como preparação de alimentos, enquanto o pavimento superior era para moradia, dormitório, manufaturas, reuniões sociais e cerimoniais, salas de estar, lavatórios, áreas de trabalho, salas de recepção e talvez salas de refeição, poderiam estar no pavimento superior, assim como as salas de armazenamento (MICHAILIDOU, 1990, p.305-306 ).

O estudo de Hallager das casas do sítio de Cania, pertencendo ao período MR I, 
apresenta a hipótese de que os pavimentos superiores eram, na maioria, lugares cobertos com espaços abertos que poderiam acomodar qualquer tipo de atividade. Baseia-se também na maquete de Arcanes e, dessa maneira, as atividades de trabalho teriam lugar no pavimento superior nas residências I e IV em espaços abertos, como terraços, acredita Hallager (1990, p. 289-292).

Shaw e Driessen afirmam que em alguns casos as paredes divisórias dos pavimentos térreos estendiam-se para o superior (SHAW, 1973, p. 146; DRIESSEN, 192; 1987, p.25). Michailidou também sugere que os pavimentos superiores ocuparam a mesma área do pavimento térreo e possuem o elemento adicionado de um telhado construído permanente (MICHAILIDOU, 1990, p.293). Nesse sentido, Graham faz uma associação entre as funções dos pavimentos térreo e o superior, sendo que as criptas com pilares ligam-se aos santuários (sala de Recepção), e as cozinhas ligam-se às salas de banquete (GRAHAM, 1979, p.49). Essa relação se faz nos três maiores palácios: Cnossos, Festos e Mália.

\section{Poursat e Schmid ${ }^{13}$ fazem uma} reconstituição dos andares superiores das quatro oficinas da quadra $\mathrm{Mu}$ (Selos, Olaria, Fundição e a Sul), que são chamadas de casasoficinas pelo fato de os edifícios possuírem locais de trabalho assim como de habitação. A oficina situa-se geralmente no pavimento inferior, em peças separadas do resto da habitação. O que chama a atenção nos

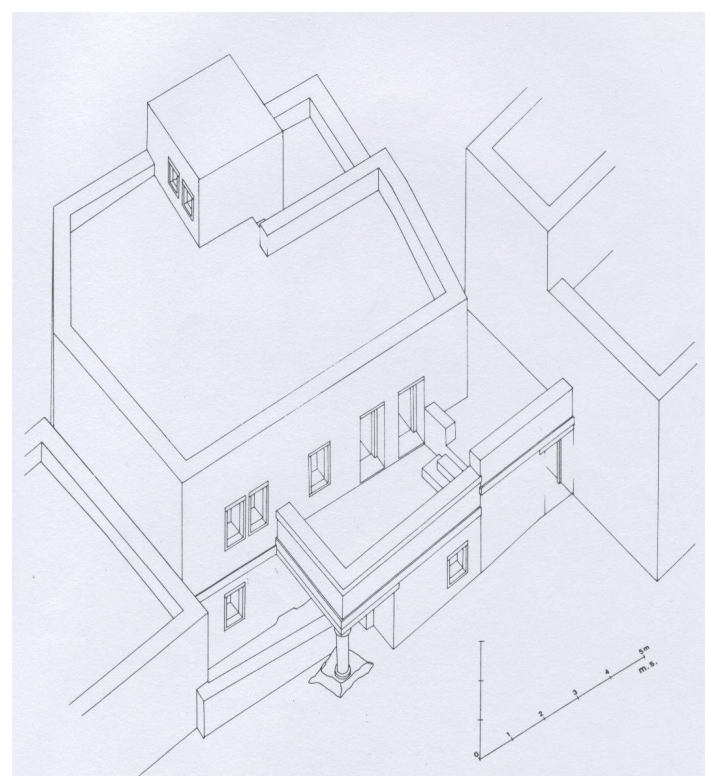

Fig. 23: Perspectiva da oficina de olaria, segundo Poursat (1996, fig.22).

edifícios da quadra Mu é o fato de eles conterem duas escadarias internas, sendo possível

13 Artisans Minoens: Les Maisons-Ateliers du Quartier MU, Poursat, Études Crétoises 32, 1996. 
identificar as mais restritas ou não. Já para a oficina sul é difícil dizer com certeza porque não possuímos o edifício inteiro, há somente uma parte dele. Mas existe a possibilidade de ser parecido. Existe também a hipótese de um terceiro andar, sendo este o bloco leve, o terraço, em todas as quatro oficinas.

Poursat e Schmid acreditam na mesma semelhança com os edifícios residências A e B, contudo, a área total das residências é quase dez vezes maior do que os locais que cada oficina ocupa. Essa questão de quantidade de escadas será discutida na análise geral. Em síntese, o autor levanta as seguintes constatações sobre estas construções:

- o atelier era situado no mesmo andar de uma casa familiar, numa peça separada do resto da habitação. São chamados de casas-oficinas (maisons-ateliers);

- pavimentos para habitação, oficinas e terceiro pavimento um terraço;

Apesar da pesquisa não se aprofundar tanto nas funções do pavimento superior, é importante ver a estrutura como um todo. Portanto, a discussão de Van Effenterre é extremamente importante para essa visão. A sugestão de blocos mostra a organização do espaço no palácio, sendo assim, uma outra concepção deles, podendo ser vistos como espaços acima de algumas quadras. Por exemplo, o bloco acima da sala hipostila, ocupa o espaço de muitas quadras do nível inferior. Assim como nas quadras XVII, XVIII e XIX junto ao bastião $\mathrm{H}$, nesse caso ligando através do pavimento superior quadras isoladas, sem circulação térrea. Já que não possuímos os pavimentos superiores para serem divididos em quadras, chamaremos de blocos. Apoiaremo-nos também na outra possibilidade, a função do pavimento superior estar ligada à função do pavimento inferior. Sem isso não teria nexo tal ligação. Como nos estudos de organização sobre circulação horizontal que abre possibilidade 
de trabalhar com acessos dentro dos edifícios nos mostrando a percepção e uso das pessoas que vivem ou viviam nessa concepção e a possibilidade dessa estar vinculada também à vertical. Dessa maneira, nessa pesquisa podemos mostrar os andares superiores somente na sua função primária: níveis superiores dos edifícios. 


\subsection{Materiais e Técnicas de Construção}

Para detalhar a construção das escadas, o estudo de materiais é um requisito imprescindível que permite afrontar o desenho das escadas de complexidade formal de acordo com os materiais aplicados na arquitetura minóica. Através do conhecimento das aplicações e dos materiais de construção pode-se transferir as possibilidades de projeção à realidade construtiva.

A típica construção minóica não era visualmente apenas um complexo como uma forma geométrica; invariavelmente os edifícios eram formações tridimensionais complexas, assim como multiforme em composição material. Basicamente os materiais das construções eram compostos de uma combinação de rochas, madeira, argila e estuque (PREZIOSI,1983, p.6).

Não foram identificadas diferenças abruptas entre os sítios nos materiais usados para as edificações durante todo o período de ocupação minóica. Os materiais usados eram praticamente os mesmos para todos a não ser por uma opção exclusiva, isso é, pelo fato de sua proveniência ser de depósitos locais. O método de aplicação também era igual assim como, provavelmente, suas ferramentas para construção. Na cidade maliota, 99\% dos materiais estão disponíveis no sítio ou em suas proximidades (EFFENTERRE, 1980, p.99).

Shaw acredita que a maior mudança nas técnicas de construção foi a introdução de blocos cortados, no período protopalacial. Para Pendleburry, contudo, essa mudança foi um subproduto de uma revolução tecnológica pela introdução do bronze, que teve um grande efeito na arquitetura, principalmente na aparência da fachada das edificações (citado por SHAW, 1973, p.12). Mas mesmo nos períodos mais tardios, como o pós-palacial, os blocos cortados eram limitados para paredes especiais e as rochas brutas foram geralmente as mais 
usadas (SHAW, 1973, p.12).

No caso da região de Mália existe uma predominância do calcário-azulado (sideropetra). além desta, podem ser apontadas seis outras formações rochosas em Mália: terra rossa, arenito dunário, calcário conchífero com detritos orgânicos, calcário compacto organo-detrítico, conglomerados e marmaropetra (EFFENTERRE, 1980, p.100-105). A ammouda, uma das rochas mais usadas nas construções de Mália, corresponde a três dessas formações, cujas variedades são: calcário conchífero, calcário compacto, organo-detrítico e arenito dunário (ALLEGRETTE, 1991. p.2).

Nas construções maliotas, a sideropetra e a ammouda foram as rochas mais usadas. No Palácio de Mália a maioria das rochas talhadas é de ammouda (EFFENTERRE, 1980, p.101), com uma coloração variável e uma maciez relativa, que pode ser cortada com mais facilidade em qualquer direção. Era muito usada no exterior do palácio, assim como em paredes internas, bases, pavimento, e também nas calçadas e pavimento do pátio central. Já a sideropetra é mais dura e sua coloração varia de cinza para um preto azulado, é resistente e muito usada como base de colunas, além de dar suporte para as vigas de madeira verticais reforçando paredes, entradas e suportar estrutura de pavimentos superiores.

Depois do calcário, a gipsita era a rocha mais usada para blocos cortados ou não. Apesar do calcário ser atraente, a gipsita possui cores elegantes, é relativamente fácil de cortar e é usada em decorações interiores, pisos, soleiras e bancos contra a parede, ombreiras de porta, pisos de escadas e também em rodapés (SHAW, 1973, p.12-23).

O xisto, também conhecido como ardósia, era usado em pavimentos, soleiras ou bases de colunas e pilares. Não era muito usado em paredes porque o xisto se separa facilmente em finas plaquetas, ou camadas, portanto, era utilizado horizontalmente (SHAW, 1973, p. 25). 
Uma outra variedade de xisto, recristalizado, mais friável, encontra-se na região de Mália, como o uso esporádico como base de coluna e soleiras na casa Épisilon de Mália. Também foi usado na série de bases de colunas no lado oeste do pátio central de Mália. Sua procedência ainda é desconhecida. Acredita-se que pode ter vindo da vizinhança da cidade de Mália (EFFENTERRE, 1963, p.27).

As outras rochas, usadas em frisos e revestimentos, bases de colunas e selecionados mais pela sua aparência do que sua dureza, são: calcário com veios, mármore, ofiolito, filito e gabro-ígnea.

Para a madeira os tipos de evidências são: cipreste, abetos (picea orientalis) e o carvalho. Identificados através do estudo antracológico (SHAW, 1973, p.175), as madeiras foram muito usadas para pilares embutidos nas paredes, colunas, como também horizontalmente: vigas, portas, degraus, ombreira de portas, janelas, reforço de paredes de cascalho, braçadeiras e buchas. É muito provável que o teto era suportado por vigas de madeira e que muito da superestrutura do

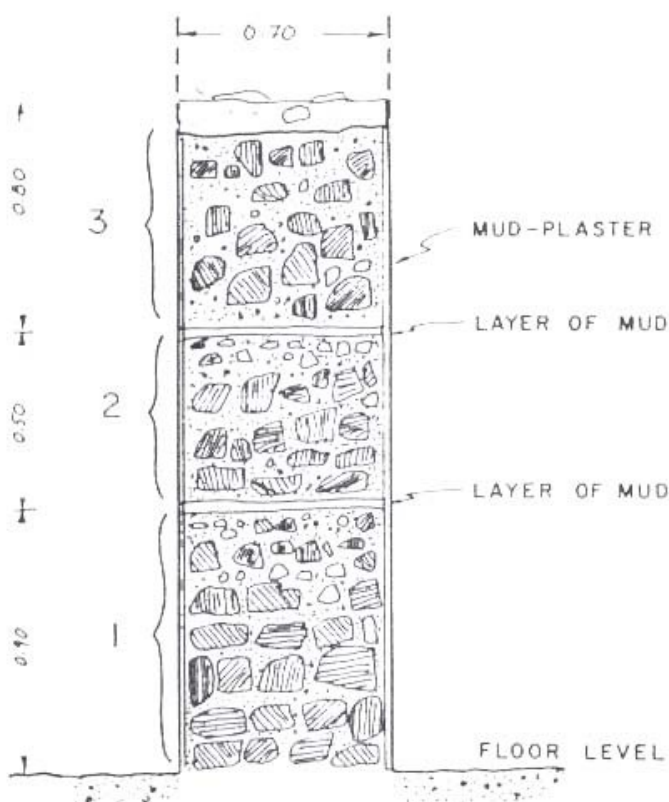

Fig. 24: Seção de uma parede da quadra I do palácio de Mália (SHAW, 1973, p.78) edifício, acima do pavimento inferior, consistisse de tijolos de barro, ou os dois juntos (madeira e tijolo) (SHAW, 1973, p.141; GRAHAM, 1962, p.158).

A argila era muito usada durante todos os períodos da construção minóica com vários propósitos, mais comumente como rejunte para muros de pedras rudes e nos tijolos de barro. Os tijolos nas construções minóicas eram usados para pisos, tetos, coberturas, telhados 
(SHAW, 1973, p.207-210).

Já em Mália talvez 5\% da estrutura visível do palácio é composta de tijolo de barro, colocado em um base em rochas pequenas, uma porcentagem muito mais elevada se comparada ao que pode ser visto em outros sítios (SHAW, 1973, p.189). Sem dúvida as paredes divisórias internas dos andares superiores eram constituídas de tijolos de barro também. $\mathrm{O}$ uso de tijolos foi observado desde o fim do período protopalacial na quadra $\mathrm{Mu}$ e no palácio de Mália, que se generaliza durante o período neopalacial (ALLEGRETTE, 1991, p.21). Como é visto nas divisões do XIII 1 e 3 do palácio de Mália, menos nas paredes externas (SHAW, 1973, p. 195).

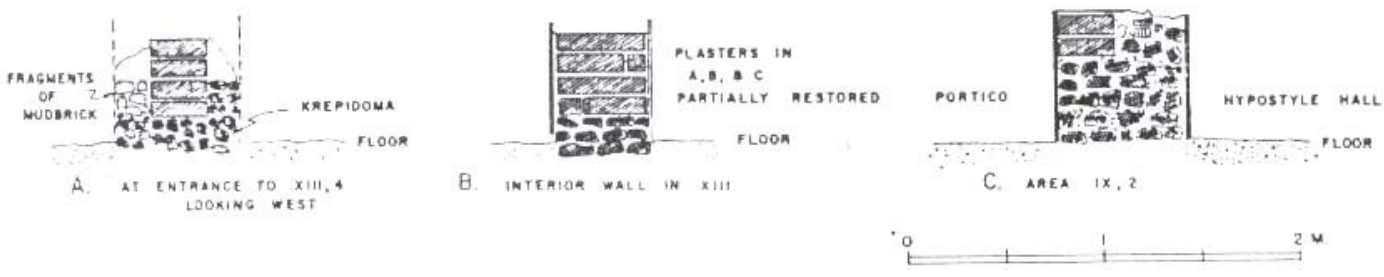

Fig. 25: Paredes do palácio de Mália (SHAW, 1973, p. 190).

O uso do reboco de cal ou argila nas paredes era comum, também usado nos pisos para cobrir degraus feitos tanto de placas rochosas como de cascalho. Os exemplos são as escadas da Cripta Hipostila em Mália (SHAW, 1973, p.207). O revestimento, além de alinhar as superfícies irregulares das paredes e dos degraus, cobrindo a composição rocha, madeira e tijolos, é excelente para proteger contra o fogo (HUGON, s.d., p.346).

Existe pouca evidência de pregos ou pinos de metal, pois o metal era mais usado na construção como ferramenta de trabalho e não nas construções em si. Principalmente nos trabalhos de metalurgia, que deveria ter uma alta especialização julgando pelos equipamentos encontrados entre as ruínas dos palácios e nos sepultamentos: caldeirões, bacias, armas e ferramentas, tanto delicadas quanto pesadas, assim como moldes para objetos de metais e 
lingotes de cobre cru.

O uso de muitas ferramentas ainda está em discussão. Seriam usadas para cortar madeiras ou rochas, para agricultura e também para afazeres domésticos. Em alguns casos permanece vago o uso e a exata variedade de ferramentas e suas especificações. Contudo, todas deveriam ter sido ferramentas básicas para a carpintaria.

Por causa disso, Shaw categoriza os tipos básicos através de suas funções (SHAW, 1973, p.45-75), como nós conhecemos hoje: enxós, machados-enxós, picaretas e enxadas, martelos, serrotes, furadeiras, talhadeiras. Com exceção do machado-duplo, que além de servir de ferramenta era também cerimonial.

As cordas e cordões deveriam ter sido usados para nivelar paredes, mas são de difícil preservação. Instrumentos de medição, níveis, esquadros e até mesmo algum tipo de fita métrica deveriam ter sido usados, mas não existe nenhum registro disso (SHAW, 1973, p. 220). Graham acredita que "em geral podemos imaginar uma unidade de medida quando existe uma regularidade e uniformidade nas plantas, como ângulos retos e dimensões parecidas entre elementos similares no desenho, um curso regular nas construções, como os blocos do mesmo tamanho" (GRAHAM, 1962, p.222) e compara as fachadas oeste de Mália, 18,19 m, de Gurnia, 18,13 m, de Festos, 18,24 m, e de Cnossos o dobro 36,23m, assim como no planejamento das construções (GRAHAM, 1962, p.226).

Shaw em seu exaustivo levantamento de todos os materiais de construção e técnicas aplicadas neles faz várias comparações de tamanho e peso com as ferramentas usadas atualmente e a grande maioria é muito parecida. Até mesmo as técnicas aplicadas, como o uso de água para lubrificar e não esquentar a lâmina dos serrotes, por exemplo, para não danificála.

Os elementos arquitetônicos que fazem parte da estrutura das construções e que 
são associados às escadas são: as paredes, os contrafortes, os pisos, as portas, os pilares, as colunas e os corredores. Esses são os elementos aos quais nos restringiremos tendo como foco principal a análise das escadas. Estas, por sua vez, será amalisada em um item à parte.

Paredes - Na grande maioria das vezes as paredes foram usadas tanto para divisórias como para sustentação dos edifícios. Dessa maneira, as paredes tendem a ser espessas, atingindo até 2,0 $\mathrm{m}$ de espessura. No geral, as construções foram erguidas sem fundações, já que o solo normalmente é sólido e estável o suficiente para a ereção das paredes e muros (fig.8, 24-26). As técnicas básicas de construção das paredes são:

a. Paredes de cascalhos, ou de blocos brutos (não aparelhados) (fig.26); ou são compostas de rochas rústicas (sideropetra ou ammouda), sem quebra, normalmente colocadas umas sobre as outras com barro ou argila para rejuntá-los (GRAHAM, 1962, p.152) e algumas vezes contendo vigas de madeira para sustentação. Essas paredes foram construídas durante todo o período minóico (SHAW, 1973, p.78). As paredes de cascalho foram utilizadas até mesmo em divisórias dos pavimentos superiores, como é evidenciado em Festos (SHAW,1973, p.78), pois com esse tipo de material é possível construir paredes finas; assim como nos parapeitos de escadas que

possibilitam sua estrutura
vertical, tanto para os
primeiros degraus (rochas)
como para os seguintes
(madeiras) e as vigas
horizontais de apoios.

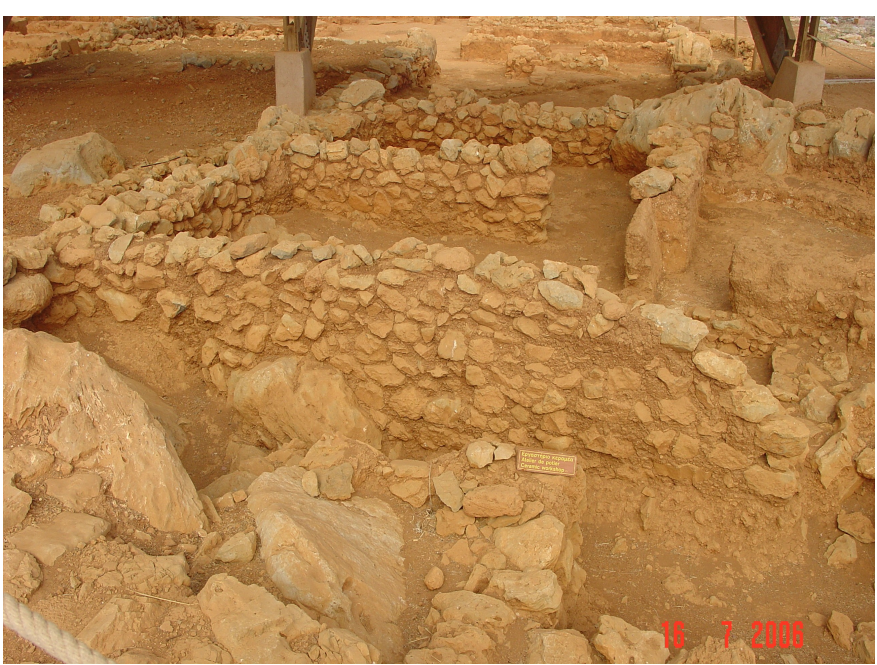

Fig. 26: Parede da Oficina de Cerâmica, quadra Mu. 
b. Paredes sem rejunte eram comuns também, uniformes ou não, mas no geral eram uniformes e as pedras eram colocadas como se fossem tijolos, uma em cima da outra, com uma camada fina de rejunte entre elas, ou simplesmente compostas de placas de calcário ou xisto, colocadas uma sobre a outra em seções, podendo ser removidas com facilidade.

c. Outro tipo de parede é a de grandes blocos cortados com uma face exterior lisa e uma outra irregular, os ortostatos, normalmente apoiados verticalmente em um dos seus lados mais longo. Esse tipo de parede foi introduzido no início da era palacial, ao qual a maioria dos exemplos conhecidos provavelmente pertence. Parece que elas eram usadas exclusivamente para fachadas importantes.
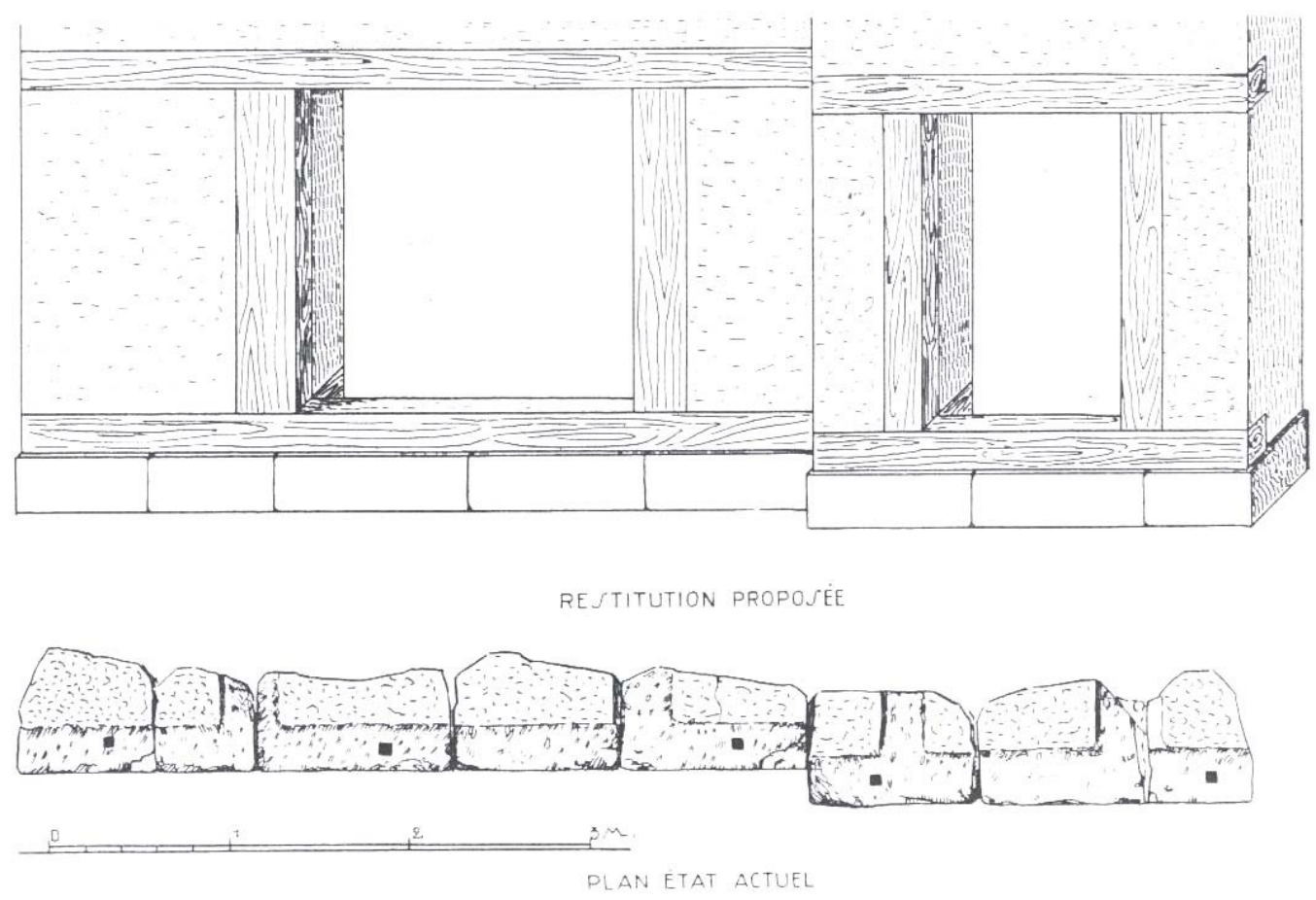

Fig. 27: Recosntituição da fachada sul do pátio central do palácio de Mália ( CHAPOUTHIER e JOLY, 1925-26, pl. III.). 
Contrafortes - São espessamentos das paredes em determinados pontos da construção, consistindo em saliências quadrangulares dispostas a intervalos de ambos os lados de uma parede, cuja finalidade parece ser a de suporte do pavimento superior, sob pontos onde haveria colunas de madeira para a sustentação do teto do pavimento (ALLEGRETTE, 1991, p.22).

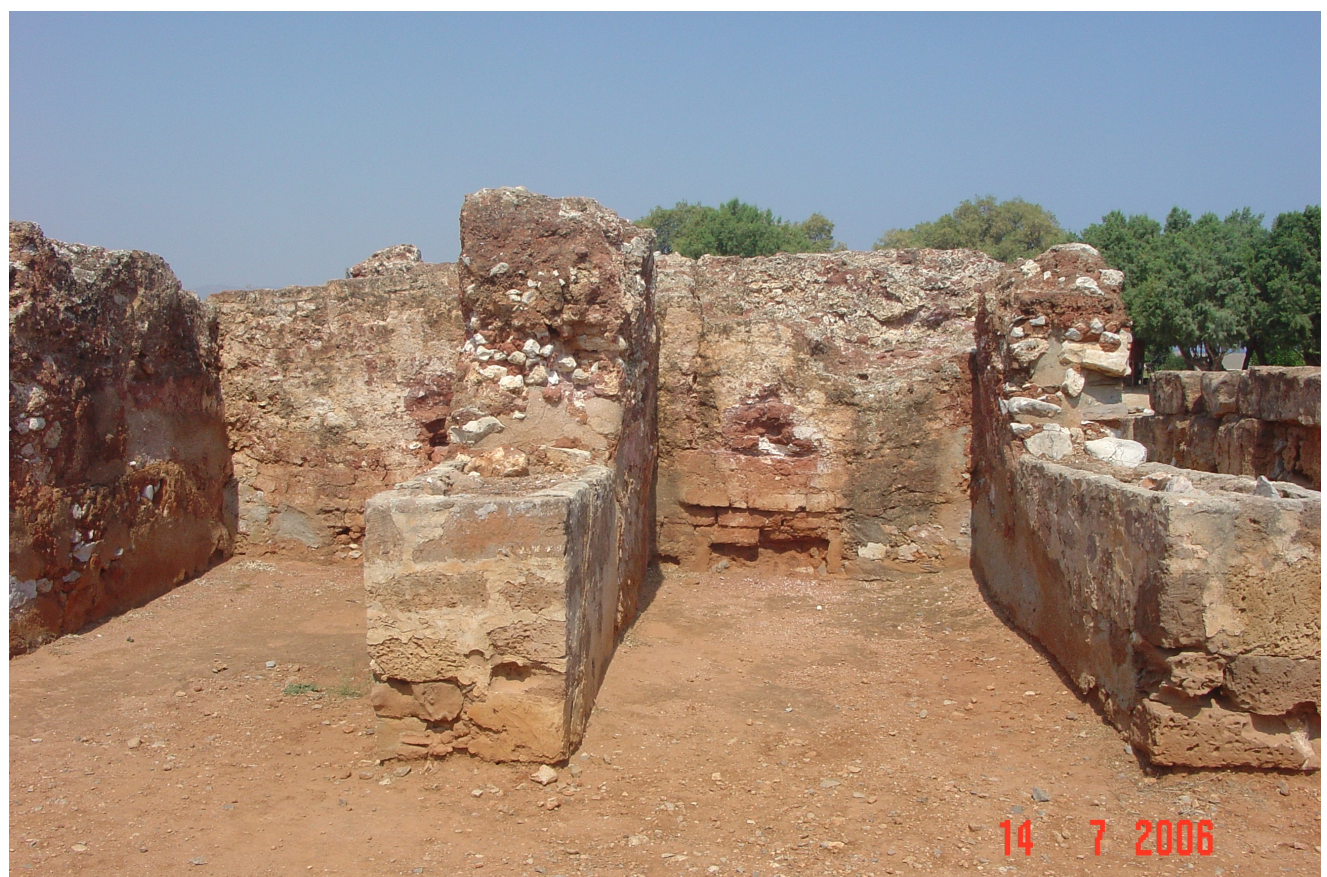

Fig. 28: Paredes das áreas I 2 e I 3, palácio de Mália.

Pisos - Na maioria das vezes os pisos eram de terra batida em uma habitação, contudo em Mália existem outros tipos de pisos, que são (ALLEGRETTE, 1991, p.23):

a. Argamassa de ammouda - uma mistura de terra argilosa com a ammouda branca esmigalhada, formando assim uma massa resistente e semelhante ao macadame.

b. Solo estabilizado - trata-se da argamassa de cal com pedregulhos e 
cascalho, formando uma camada de pouca resistência à umidade, porque é fina, com um ou dois centímetros de espessura.

c. Terrazza - uma argamassa de argila e cal na qual são misturados fragmentos de cerâmica, pedra-pome triturada ou restos de tijolos cozidos, resultando em uma superfície resistente e impermeável.

d. Estuque - de composição similar ao empregado nas paredes, é aplicado sobre uma camada primária de terra batida ou cascalho. Um ponto a destacar refere-se ao fato de que nas salas do palácio, onde tanto as paredes quanto os pisos eram estucados, nota-se que isso ocorreu antes que se construisse degraus ou bancadas nesses espaços, ao invés de estucar após a implantação daqueles, como se esperaria.

e. Lajeados - Encontra-se neste tipo de piso:

- Kalderim - é o mais simples, consistindo de pedriscos que formam uma camada de base para a colocação de pedras grosseiras aplainadas;

- Mosaiko - uma outra forma, na qual pedras espaçadas são colocadas

sobre uma

base de terra

rossa ou

estuque;

- Placas

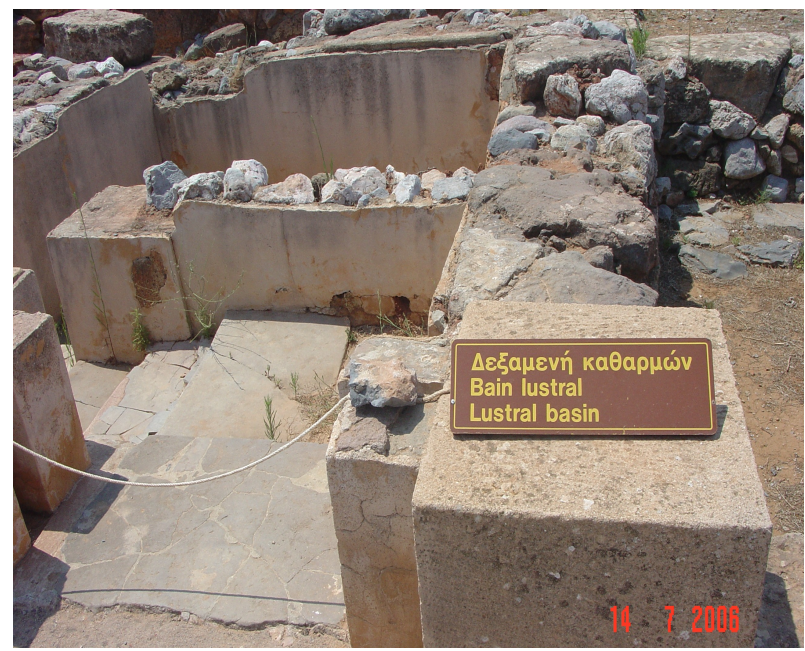

de placas

Fig. 29: Piso em placas da sala lustral do palácio de Mália. 
finas em gipso, xisto, ammouda ou sideropetra que são dispostas lado a lado, paralelamente às paredes;

- Pranchado - piso em madeira disposto de pranchas paralelas. Não existe vestígios diretos desta técnica, apenas as marcas no estuque sobre o qual eram instalados.

Portas - a identificação de portas tem sido possível devido a dois tipos de indícios: o primeiro são as soleiras, que na maioria das vezes consistem em blocos aplainados de sideropetra ou xisto situadas em aberturas das paredes ou à entrada de certos recintos. Estes blocos apresentam em vários casos marcas curvas concêntricas que se supõe terem sido provocadas pelo atrito de batentes de portas, além de orifícios situados no ângulo dos blocos que seriam destinados a receber o pivô do batente da porta. O segundo tipo de indício corresponde ao contorno das paredes no ponto em que interrompem para dar lugar às aberturas das portas: no sentido da espessura da parede, esta apresenta de um a dois ressaltos verticais ao longo de sua altura formando ângulos retos com a mesma e, neste ponto, na soleira, está localizado o orifício do pivô da porta. Pelo que se pode inferir, tais ressaltos serviriam para abrigar o enquadramento da porta. Do que se pôde descobrir a partir de vestígios similares em Mália e em outros sítios, a porta se compunha de uma soleira em pedra, alizares laterais em madeira e um lintel de pedra, podendo ter de um a dois batentes fixados a eixos verticais de madeira que se apoiavam nos orifícios da soleira e no lintel, sendo os batentes fixados aos eixos por meio de correias de couro ao longo de sua altura. No caso das escadas, as portas são encontradas em apenas algumas na parte inicial inferior, restringindo-se a locais cuja circulação se refere a áreas de maior importância. É o caso da porta dupla situada na base da grande escadaria VI 8 do palácio de Mália. Lá foi encontrado um casco de bronze, 
interpretado como um reforço para a base do eixo que penetra no orifício da soleira desta porta (CHAPOUTHIER e CHARBONNEAUX, 1928, p.32, pr. XX,1 citado por ALLEGRETTE, 1991, p.24).

Pilares e Colunas - Ambos são empregados na arquitetura minóica com finalidades distintas. O pilar se distingue da coluna por possuir uma seção quadrangular, compondo-se normalmente de dois a três blocos cúbicos de ammouda sobrepostos, para suportar o peso de um pavimento superior, como os pilares nas salas IX 1 e 2 do palácio, e algumas vezes no qual haveria um outro pilar, apoiado sobre o inferior. Também são assimilados pilares de madeira apoiados sobre bases de sideropetra ou xisto, destinados à divisão de espaços e suporte de tetos. A coluna se diferencia do pilar por ter uma seção circular, compondo-se de uma base de pedra tronco-cônica ou cilíndrica sobre a qual é colocada uma coluna de madeira arredondada que pode atingir até 4,0 $\mathrm{m}$ de altura. Dos diversos minerais que compõem a coluna, destacam-se a sideropetra, o xisto, o mármore branco, o calcário cinza e o conglomerado.

Corredores - Dispositivos destinados primordialmente à movimentação, compreendidos como elementos de circulação horizontal no interior das edifícios, delimitados por paredes e cobertos, tendo como finalidade a ligação entre aposentos pertencentes a um mesmo conjunto ou a mesma quadra. Veremos que muitas das escadas, principalmente as dos edifícios de habitação, estão conectadas a corredores, que por vezes tem sido considerados como integrantes dos edifícios, ou como elementos numerados e referenciados à parte, como por exemplo os corredores C e C' no palácio (ALLEGRETTE, 1991, p.88-89). 
Todos os aspectos e elementos cidados acima estão integrados tanto no espaço privado como no público.

Existe, no entanto, um outro tipo de espaço construído no palácio que não possui uma função definida e que foi denominado Bastião, caracterizado pela ausência de acesso. Dentro do palácio de Mália encontramos oito espaços marcados $\mathrm{A}-\mathrm{H}$ identificados dessa maneira, mas dois deles já foram desqualificados (A e B). Esses espaços poderiam estar ligados, também, à estrutura de suporte das escadarias, pois em alguns locais onde as escadas aparecem no palácio, existe no seu entorno um bastião. 


\subsection{Escadas}

Assim como as paredes, os corredores, e as portas comentadas anteriormente, as escadas também fazem parte dos elementos arquitetônicos de movimentação que têm como princípio a existência de uma diferença entre duas áreas separadas por esses dispositivos, tanto de desnivelamento como de pavimentos distintos. Mas se diferenciam pelo fato de sua separação não ser um barreira material à circulação. Dessa maneira, Allegrette ressalta que a escadaria efetiva uma diferenciação de altura entre dois locais, criando uma barreira psicológica (ALLEGRETTE, 1991, p.106). Na medida em que possibilita acesso a um plano mais elevado ou mais rebaixado, possui um caráter distinto e particular, significando mais para o aspecto que diferencia níveis de um mesmo espaço horizontal. Já para os diferentes pavimentos, espaços distintos, Allegrette observa também que tanto os corredores como as escadas criam uma área de transição entre locais sem comunicação imediata e efetuam um bloqueio visual entre tais locais, permitindo a sua conexão, mas impedindo que as atividades de uma determinada área sejam perceptíveis a outra área (ALLEGRETTE, 1991, p.107).

A escada possui nexo enquanto elemento de composição no qual identifica-se o todo como um conjunto unitário que o indivíduo nunca conhece inteiramente mas ele não deixa de reconhecer (TEIXEIRA NETTO, 1999, p.10), nesse mesmo sentido Teixeira Netto discute a temporalização do espaço, no qual a escada cria um jogo de permutação entre o horizontal e o vertical, propondo desníveis e direcionando um subir e descer, rompendo assim uma monotonia, deixar de lado um espaço que se vê para adotar um espaço que efetivamente se percorre, onde o movimento é não só possível como exigido, um artifício de temporalizar o espaço, enfim vivido (TEIXEIRA NETTO, 1999, p.78). Dessa maneira, cabe aqui citar o arquiteto Nuet, que na sua definição disse que "a escada, além de ser um elemento 
tridimensional, é um declive escalonado com efeito ótico que resulta em uma troca contínua de perspectiva transmitida por ela. Essa sensação reforça a verticalidade como linha de movimento, tanto para cima como para baixo" (NUET, 1994, p.12).

Essa é uma perspectiva de abordagem para o estudo das escadas minóicas, no sentido imaterial, por assim dizer. Como declarou a engenheira alemã, Christine Ruth Hansmann, "as escadas são mais que meros elementos de comunicação. Ao longo da história foram julgadas por seu importante papel na representação do poder e na hierarquia social. Seu simbolismo não pode se desassociar em muitos aspectos, nem da arte e nem da publicidade. Como elemento de formalização, as escadas influem em grande medida na funcionalidade dos edifícios, tanto nos seus interiores como em seus exteriores e também no âmbito fronteiriço" (HANSMANN, 1994, p. 10).

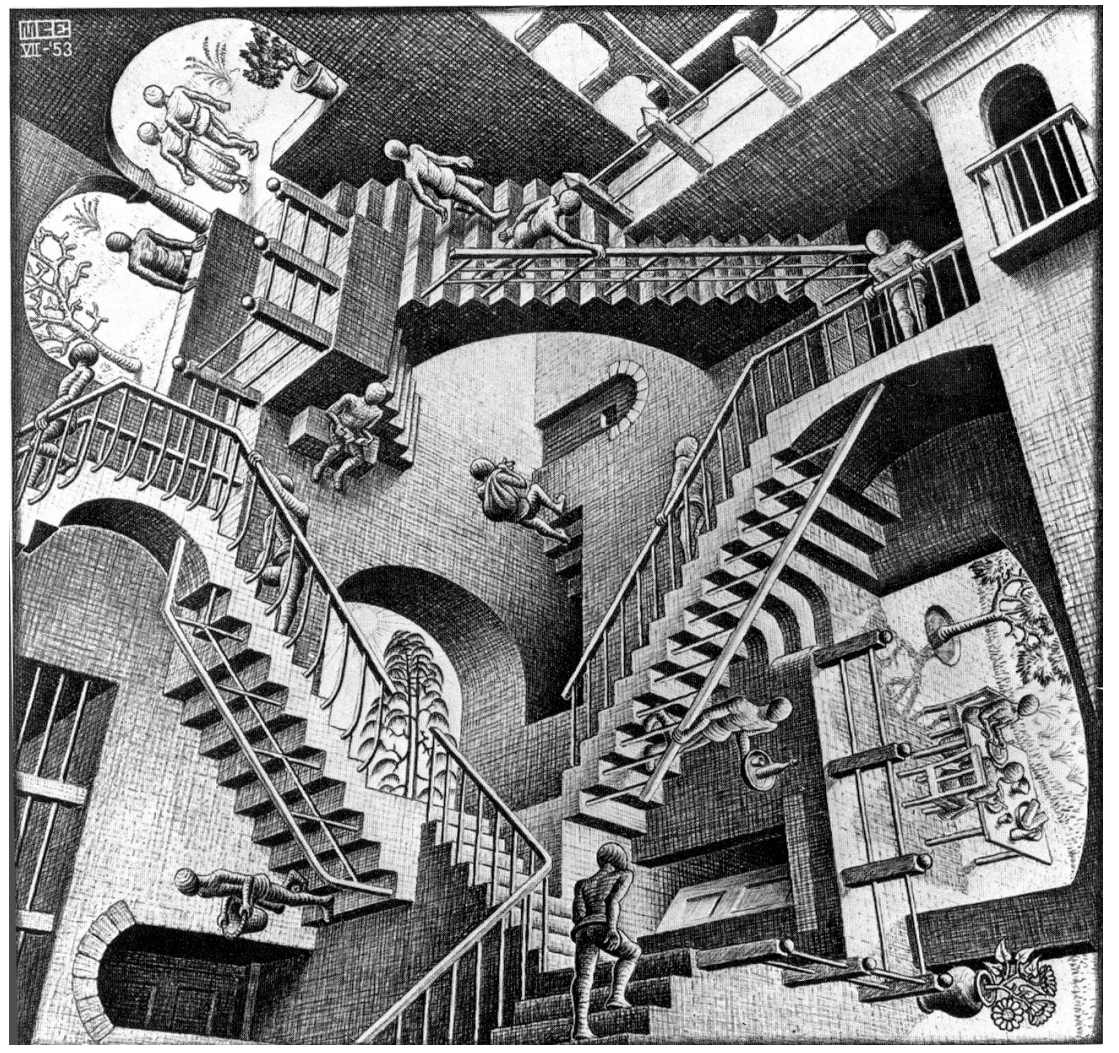

Fig. 30: Relatividade, litografia, Escher, 1953 (ERNEST, 1991, fig.95). 
A escolha pelas vias verticais de transição deve-se às suas diferentes funções. As escadas não serão tratadas apenas como elementos de circulação. O estudo é direcionado também para os aspectos de demarcação territorial e fronteiriço (PALYVOU, 1987; SANDERS, 1990; ALLEGRETTE, 1991; HANSMANN, 1994; NUET, 1994) no sentido das diferentes e isoladas concepções que levaram à construção de escadas para diferenciar um pavimento do outro. O objetivo dessas observações, nessa pesquisa, é a verificação da existência de padrões de uso dos elementos verticais.

A escada se comunica com o resto da construção e define sua localidade dentro de um padrão de circulação. Portanto, sua freqüência de uso, sua importância e acessibilidade definem o grau de privacidade. $\mathrm{O}$ arranjo está relacionado à organização espacial, um caráter planejado, ou seja, o processo de construção do espaço já incorpora a circulação interna como um de seus componentes (ALLEGRETTE， 1997, p.11). Sob o mesmo ponto de vista, Rapoport afirma que "de acordo com diferentes regras, costumes, normas, os quais refletem as atividades, valores e propósitos dos indivíduos ou grupos fazem a organização espacial” (RAPOPORT, 1982, p.179).

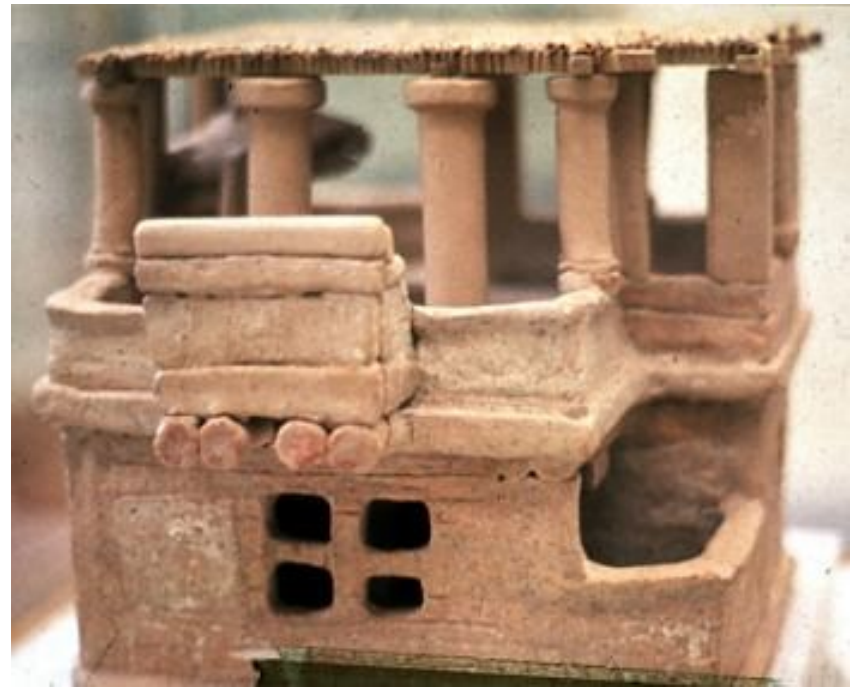

Fig. 31: Modelo de Arcanes (SAKELLARAKIS, 1997, fig. 564).

Voltando à declaração do arquiteto italiano Vicenzo Scamozzi, ele afirma que "dentre todos os elementos arquitetônicos, as escadas são para o edifício o mesmo que as artérias e as veias para o corpo humano. São imprescindíveis para a comunicação e nesse 
sentido a escada seria como o coração de um edifício, enchendo-o de vida""14 .

Quanto a essa questão, Graham declara que a arquitetura minóica "display a remarkable appreciation of the possibilities of stair arquitecture” (GRAHAM, 1962, p.180). Essa frase do autor sobre a importância das escadas tem vários significados. Primeiramente, porque a escada é um elemento constante tanto nos palácios como nas residências, privadas ou públicas. Segundo, é através delas que temos prova de outros andares. Por fim, ele mesmo explica no seu livro que "as escadas consistem em um importante elemento, mas os palácios não eram certamente planejados em volta de uma série de grandes escadarias." (GRAHAM, 1962, p. 242).

É aqui que Graham discorda da opinião do pesquisador Rodenwaldt, que declarou que "o motivo dos degraus e escadas poderiam ser o centro de um sistema das estéticas da arquitetura cretense" (citado por GRAHAM, 1962, p.180). É através desse argumento que Rodenwaldt sugere que as escadas eram um princípio dominante na composição dos palácios (GRAHAM, 1962, p. 242).

Apesar de não ser exagero citar a importância das escadas para a arquitetura minóica, não podemos afirmar a tal ponto que esse elemento era o centro do projeto construtivo. Essa referência não está relacionada somente às características arquitetônicas, onde a maioria das construções possui esse elemento de conexão vertical que conectava até quatro andares, mas também no desenho urbanístico que, exclusivamente por causa das escadas e dos pavimentos, produzem um diferencial na paisagem o qual modifica e caracteriza um skyline totalmente novo no horizonte da cidade. Assim como a configuração de fachadas, essa evidência é comprovada pelos materiais iconográficos (fig. 13 - 16 e 31).

Para isso mostraremos a complexidade de sua construção. Assim como Shaw e 14 Vide página 02. 
Graham acreditam e fazem paralelos etnográficos das maneiras e técnicas construtivas antigas e atuais, veremos que as mudanças em suas construções feitas ao longo do tempo consistem de inclusões de materiais e formas diferentes. Contudo, até os nossos dias usamos princípios semalhantes no desenho que foram usados para arquitetura minóica.

Temos indícios, na arquitetura minóica, das construções das escadas internas de várias maneiras e formas. Elas foram construídas com blocos de rocha apoiados em uma base sólida, para escadas com poucos degraus e pequenos desníveis, ou para pavimentos diferentes. Como também construíam estruturas de madeira para os apoios, até mesmo suportados por vigas em declives, cujos encaixes eram visíveis nas paredes (GRAHAM, 1962, p.183). Essas vigas assemelham-se aos atuais "dormentes longitudinais". Os demais andares devem ter sido construídos somente de madeira por causa do seu peso, pois normalmente não era prático construir uma base sólida para suportar todo o peso de uma escada de um andar para o outro, porque as rochas são muito pesadas para serem usadas nos níveis acima do chão. Existem alguns espaços onde é provável que houvesse escadas, apesar de não termos evidências diretas (os primeiros degraus) para isso, apenas a constatação dos vãos que elas poderiam ocupar.

Em alguns casos, também abaixo dos degraus de madeira, o espaço foi ocupado por armários. No palácio de Festos, por exemplo, o espaço sob a escada na área 42/43 foi aproveitada como armário, onde cerâmicas domésticas em grande quantidade foram achadas (GRAHAM, 1962, p.183), ou até mesmo por banheiro, como é o exemplo de Sklavokambos. Isso mostra uma ocupação do espaço sem desperdícios, outro uso e aproveitamento do espaço que a escada se insere quando não está ocupado por uma base sólida.

Existem evidências de escadas de uma só extensão ou um só lance, podendo se situar paralela a uma parede, caracterizando-as com uma configuração tipo I. Mas as 
configurações mais comuns usadas pelos construtores cretenses eram a tipo $\mathbf{L}$ e $\mathbf{U}$. O tipo $\mathbf{L}$ é uma escada de dois lances normais e ocasionalmente as escadas foram construídas com ângulos retos entre elas contra lados adjacentes de uma sala, possuindo dessa maneira um patamar intermediário, paralelo a duas paredes, ou usando a esquina do muro. Já o tipo $\mathbf{U}$ costuma ser apoiado a uma parede central, também possuía um patamar intermediário, e na maioria das situações possui um espaço próprio, onde provavelmente o segundo lance tinha aproximadamente o mesmo comprimento do primeiro.

Como foi comentado anteriormente, tanto no $\mathbf{L}$ como no tipo $\mathbf{U}$, foram construídos lances contra uma parede. Algumas vezes estas paredes foram construídas na altura exata da borda externa da escada, no entanto, não existe restos arquitetônicos em qualquer instância; normalmente poderiam ser estendidas como paredes sólidas até o teto. Uma parede sólida, entretanto, criaria uma escada muito escura, e talvez por causa disso fossem feitas aberturas; como na Grande Escadaria da Quadra Residencial de Cnossos, onde os construtores audaciosamente substituíram tais paredes por colunas de vão livre.
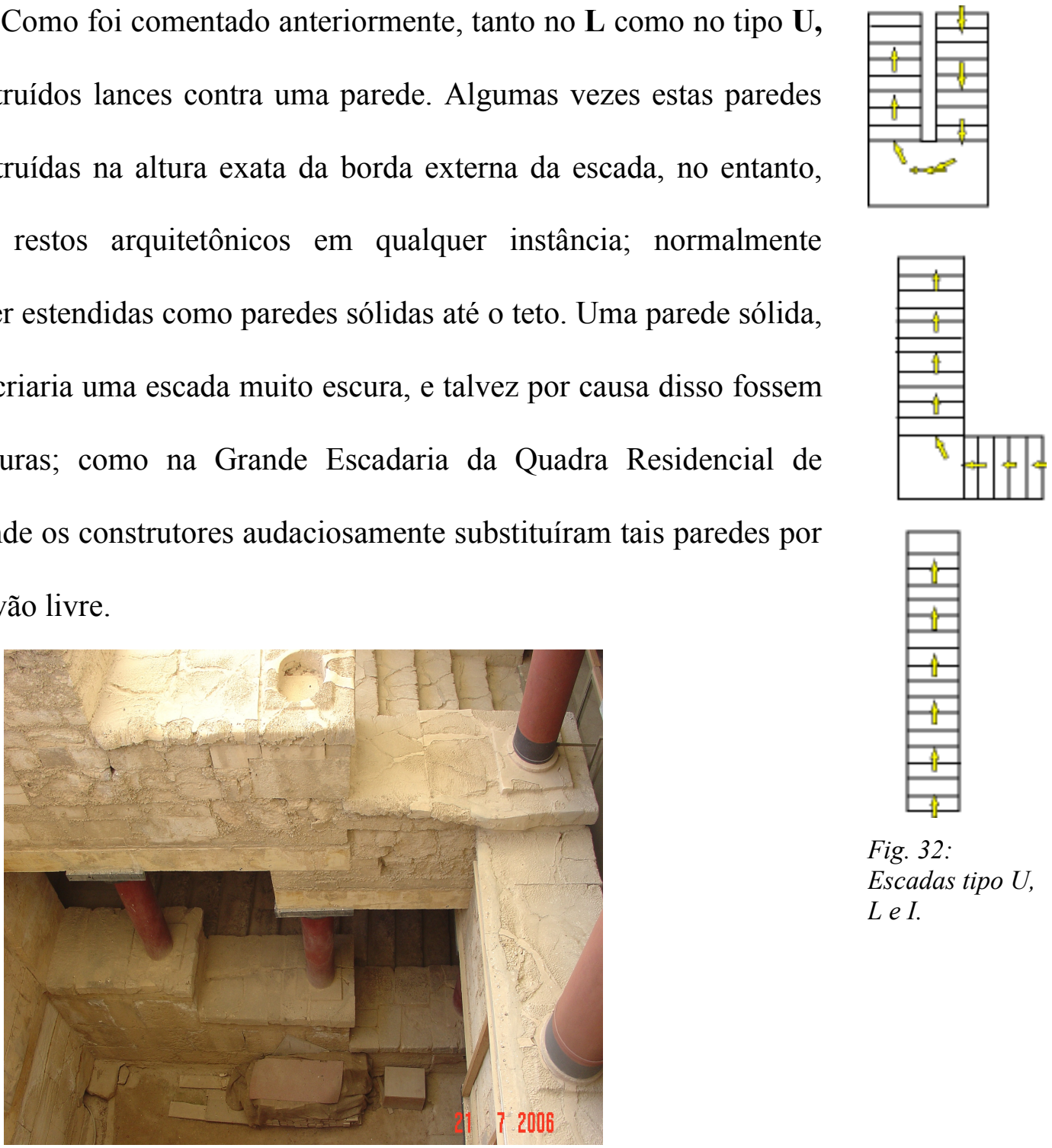

Fig. 33: Grande Escadaria do palácio de Cnossos, quadra residencial. 
Foi possível localizar ao menos um ensaio de reconstituição do processo construtivo de uma escadaria tipo $\mathbf{U}$, monstrando suas vigas e paredes de apoio, de acordo com Sakellarakis para o edifício de Arcanes, para o período neopalacial (SAKELLARAKIS, 1997, p.93).
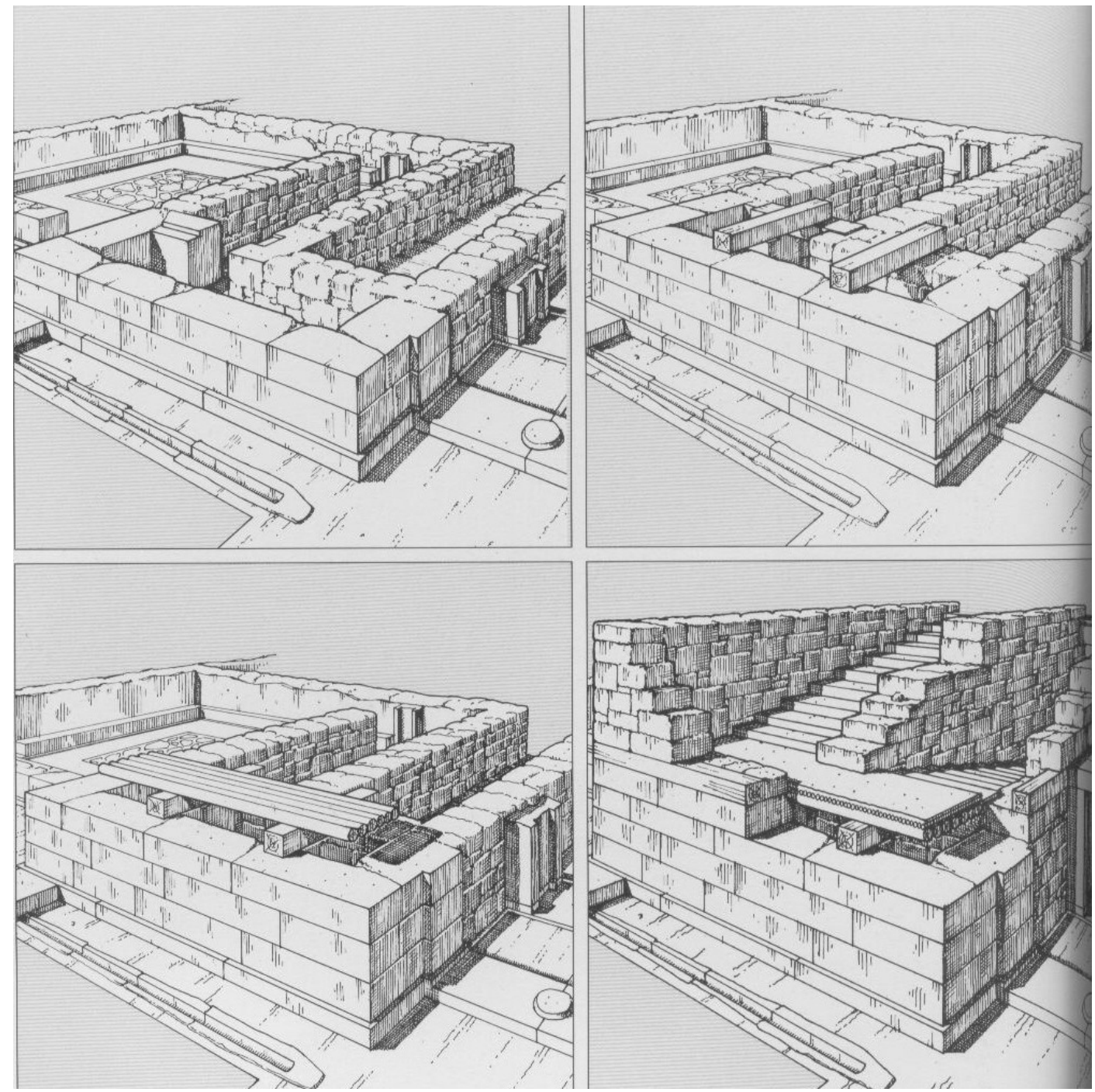

Fig. 34: Processo construtivo de uma escadaria, exemplo sugerido para Arcanes (SAKELLARAKIS, 1997, dwg.13) 
Para a maioria dos espaços construídos pelos minóicos foram identificadas características próprias. Apesar de não fazer parte desse estudo, não se pode deixar de mencionar que um elemento que faz a sala lustral identificável em qualquer planta dos edficios minóicos é a presença de escada do tipo $\mathbf{L}$, sem ela o módulo não é caracterizado como lustral. Poderíamos mencionar aqui também a sala de Banquete, pois apesar de termos especulações bastante interessantes sobre esse espaço, elas ainda não foram comprovadas.

Agora quanto aos critérios e fundamentos técnicos para as construções das escadas em geral atual, podemos nos apoiar no que hoje possuímos, pois sua fisionomia, objetivo e uso continuam os mesmos.

Os degraus eram, pelo menos os primeiros, feitos de rocha resistente como a ammouda apoiados em terra batida, ou pedregulho, enquanto o restante eram feitos de madeira, por causa do peso. Normalmente, encontram-se no máximo seis degraus, in loco, de larguras que variam de 0,80 a 2,00 m, de 0,40 a $0,60 \mathrm{~m}$ de profundidade e de 0,12 a $0,17 \mathrm{~m}$ de altura (HUGON, s.d., p. 350). Atualmente é usada essa mesma medida para altura dos degraus, sendo as de $0,12 \mathrm{~m}$ para as escadas monumentais e 0,19 para as escadas de serviço (HUGON, s.d., p. 352). Um lance de escada contém aproximadamente quinze degraus no seu total. Acima disso são criados intervalos usando patamares. Em relação a Mália, observamos que esse padrão é também usado.

Hoje existe um padrão para as larguras das escadas conforme seu objetivo: para acessos públicos a largura varia de 1,50 a 2,00 m; para acessos administrativos, variam de 1,20 a $1,50 \mathrm{~m}$; nas habitação podem ser de 0,80 a $1,20 \mathrm{~m}$; e as de serviço variam de 0,70 a 0,80 m (HUGON, s.d., p. 351). Mais um indício que podemos verificar para as escadas das construções minóicas. 
Um outro aspecto bastante interessante e que pode nos dar pistas de seu uso é sua inclinação. Um escada necessita de um ângulo certo para ela ser construída. Quanto mais inclinada ela for, mais restrito o seu uso, maior o esforço físico e menos espaço ela ocupará dentro da construção, pois menos degraus serão necessários para atingir o próximo pavimento. Quanto menos inclinada, mais pública ela pode ser, mais espaço ela ocupará, menos esforço necessitará e maior ela será. Esse tipo de técnica também foi usada nas edificações minóicas, contendo entre 26 a $28 \%$ as mais importantes, e as outras entre 34 a 64\%. (EFFENTERRE, 1980, p.309).

\begin{tabular}{l|c|c|c|c|c|c}
\hline \multicolumn{1}{c|}{ Quartiers } & VI & IX & XIII & XVII S & XVII N & XXII \\
\hline Emprise totale des marches (cm) & 310 & 280 & 105 & 90 & 180 & 275 \\
\hline $\begin{array}{l}\text { Hauteur totale des marches (cotes } \\
\text { cumulées) }(\mathrm{cm})\end{array}$ & 84 & 73 & 51,5 & 58 & 61 & 78 \\
\hline $\begin{array}{l}\text { Pente moyenne }(\%) \\
\text { P. }\end{array}$ & 27 & 26 & 49 & 64 & 34 & 28 \\
\hline
\end{tabular}

Fig. 35: Cáculo da inclinação de algumas escadarias do palácio de Mália, segundo Van Effenterre (1980, fig.306).

A identificação de poços de escadarias na arquitetura minóica é baseada nas evidências diretas, que primordialmente são os lugares onde são encontrados os degraus in loco durante as descobertas dos edifícios. Usaremos essas evidências como referência para identificar espaços destinados às escadas sem o fator primordial, os degraus. Como comentamos anteriormente, as escadas eram construídas de blocos maciços e madeira ou apenas de madeira. Para as escadas, cujos degraus eram de madeira, não há resquícios devido a sua difícil conservação. Existem vários espaços que poderiam se encaixar nessa técnica de construção. 
Um dos primeiros indício são as formas das peças. Uma escadaria do tipo $\mathbf{U}$ ocupa normalmente duas peças ligadas entre si. Seria um pequeno corredor onde no final se faz uma curva e desemboca em outro igual e parelelo ao primeiro, esse segundo corredor é muitas vezes fechado. Quando o segundo corredor não é fechado, acaba formando um conjunto de duas peças compridas paralelas uma a outra. Ela não possui características de uma sala pelo fato de sua largura ser somente o suficiente para uma ou duas pessoas de pé (uma ao lado da outra).

Portanto, já apontamos a forma e dimensões para sua identificação de um poço de escadaria de acesso a níveis superiores.

Já para as escadas tipo $\mathbf{L}$ seguem o mesmo raciocínio, contudo o segundo lance não é paralelo e muitas vezes elas estão em cantos de salas, e quando não estão, formam também uma peça cujas dimensões são da largura de um corredor de passagem e comprimento longos, mas não tão longos como certos corredores que interligam salas.

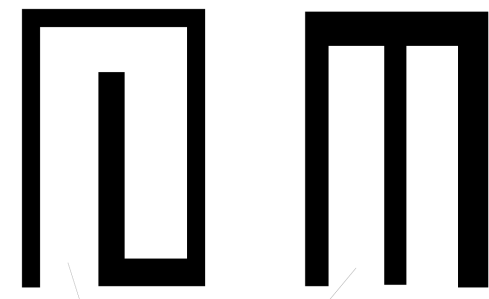

Poço de escadaria tipo $U$
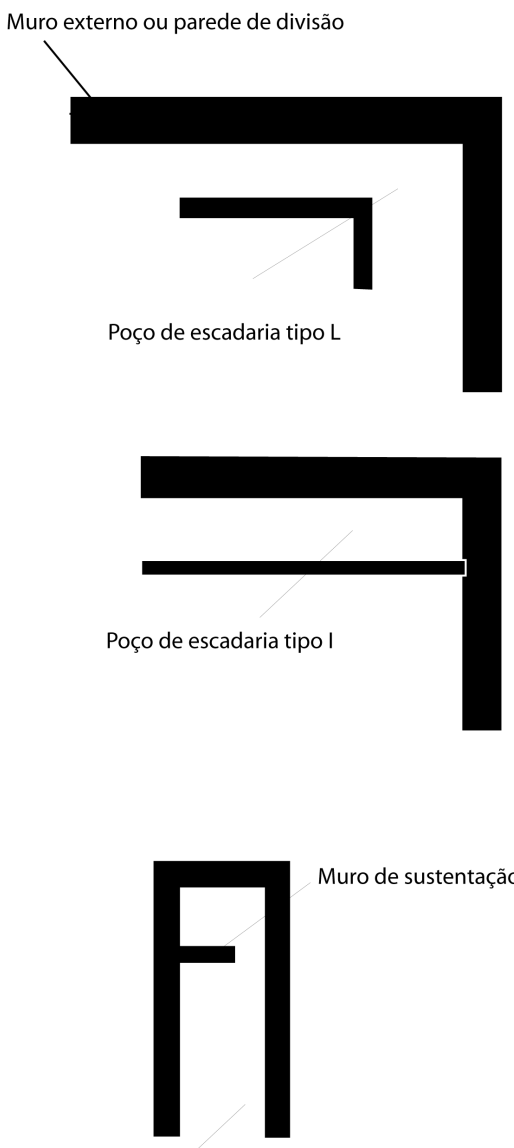

Muro de sustentação

Poço de escadaria tipo I

Fig. 36: Desenhos de vãos para cada tipo de escadarias, I, $\boldsymbol{L}$ e $\boldsymbol{U}$.

As escadarias tipo I, são como as $\mathbf{L}$, contudo, não possuem um segundo lance e seguem o mesmo princípio. Apoiadas às paredes da construção ou possuindo uma peça que não se destina à comunicação horizontal, podemos indentificá-las se as salas à sua volta possuirem outras maneiras de entradas. Assim, esse corredor acaba não ligando as salas no 
seu entorno.

Acabamos de apontar também um outro critério, a disposição da peça. Muitas vezes quando isso acontece a peça já está ligada a um corredor, não importando seu tipo (U, $\mathbf{L}, \mathbf{I})$.

No entanto, não podemos nos apoiar somente na forma, nas dimensões ou na disposição. Devemos também observar o seu entorno, principalmente as estruturas de apoio da construção. Na grande maioria das vezes as paredes em volta dessas peças são espessas, inclusive, pode haver muros perpendiculares nessas paredes que sustentariam um patamar intermediário. Esses muros perpendiculares podem ou não se conectar a outra parede. Quando conectados acabam formando outros espaços pequenos e sem conexão para o exterior, muito frequente nos bastiões. E quando não conectados são mais parecidos com saliências. Para muitas construções, as paredes de certos setores são totalmente mais espessas que outras. Isso é mais um indício de sustentação, não somente para uma escadaria como também, para o pavimento superior, que pode nos levar a acreditar em outros andares acima do segundo pavimento. Assim como, as referências bibliográficas que descrevem, algumas vezes, o material encontrado durante as escavações e os negativos dos apoios de vigas nas paredes, quando existem.

E uma última observação são os conjuntos de peças que não possuem passagens para outros setores pelo térreo. Esses espaços nos levam a crer que sua conexão seria somente através de escadarias cujo o acesso é pelo nível superior. Na maioria das vezes nesses conjuntos indentificam-se espaços específicos para a escadaria, anteriormente comentado, tanto na forma, como nas suas dimensões e disposições.

Esses são os critérios que nos basearemos para identificar a existência de poços de escadarias que não possuem evidências diretas. 
O catálogo das escadas se apoiará em todos esses pontos levantados anteriormente. Tanto nos critérios para identificação dos poços de escadarias, nas características formais das escadarias, traçando paralelos possíveis entre as técnicas e padrões construtivos antigos e modernos. 


\section{Catálogo das Escadarias}

A partir de agora passaremos a apresentar o corpo documental definido conforme os critérios anteriormente estabelecidos, apontaremos as evidências nos edifícios maliotas e suposições levantadas por pesquisadores sobre a possibilidade da existência de escadas sem indícios diretos e as reconstituições feitas em algumas das escadarias. Assim como considerar as possibilidades de observação e análise das construções.

Partiremos inicialmente pelas escadarias das estruturas privadas, que efetivamente são: (3) casa Delta Beta, (1) casa Delta Alfa, (3) casa Épsilon, (1) casa Zeta Alfa, (2) casa Zeta Beta, (4) casa $\mathrm{Mu} \mathrm{A,} \mathrm{(2)} \mathrm{casa} \mathrm{Mu} \mathrm{B.} \mathrm{Posteriormente} \mathrm{passaremos} \mathrm{às} \mathrm{estruturas} \mathrm{públicas:}$ (3) Cripta Hipostila e o Palácio - (1) Quadra I, (1) Quadra II, (1) Quadra IV, (1) Quadra VI, (1) Escadaria Monumental, (1) Quadra IX, (1) Quadra XIII, (1) Quadra XVII, (1) Quadra XIX, (1) Quadra XXI, (1) Quadra XXII, (1) Quadra XXVII. Trabalharemos com um total de trinta e uma escadarias. 


\section{$\underline{\text { 3.1.Edifícios Privados }}$}

\section{Quadra Zeta}

Pela saída sudeste do palácio, seguindo-se por uma via de ammouda com largura de 1,40 m e 86,00 m de comprimento, começa um simples kalderim, defronte do qual nos deparamos com a quadra Zeta. Encontram-se ali três residências que fazem parte dessa quadra de habitação: Zeta Alfa, Beta e Gama. Situam-se ao leste do palácio e foram descobertas em 1928. Depois, em 1946-48, uma série de sondagens foram realizadas, permitindo discernir a topografia geral e delimitar completamente a quadra e as casas. Os vestígios encontrados na quadra datam do período protopalacial e neopalacial (DESHAYES e DESSENNE, 1948-54, p.63-79).

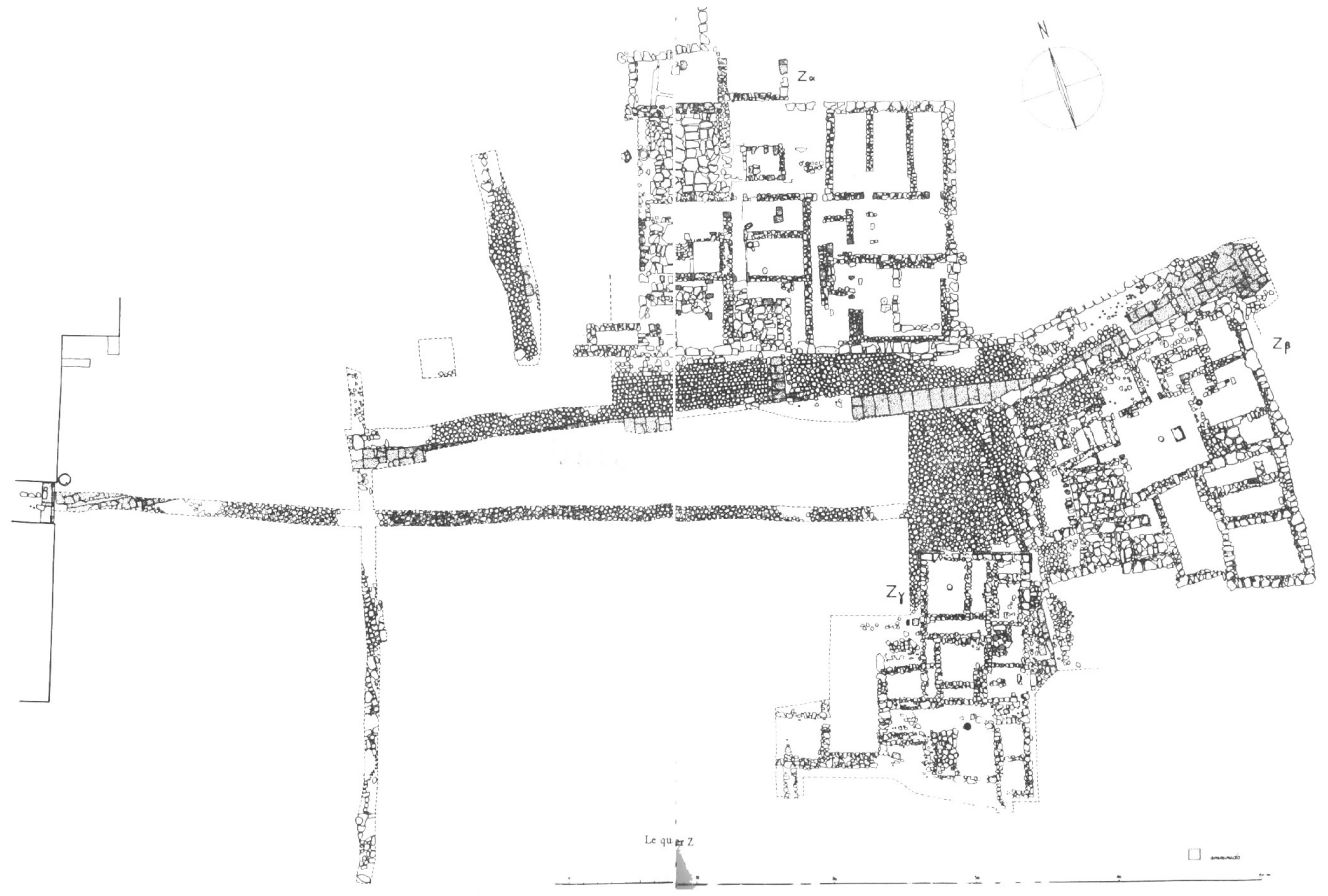

Fig. 37: Quadra Zeta (DESHAYES e DESSENNE, 1948-54). 
Quando foi descoberta essa quadra os pesquisadores Demargne e Santerre acreditavam que as casas eram, sem dúvida, as mais ricas da cidade (DESHAYES e DESSENNE, 1921-1948, p.64). Contudo, percebeu-se posteriormente que as residências da quadra Zeta eram simples comparadas as da quadra Épsilon, descoberta em 1931 pelo pesquisador F. Chapouthier (CHAPOUTHIER, 1948-54 ,p.91).

Saindo do palácio em direção à quadra Zeta, deparamo-nos primeiramente com a casa Alfa, à noroeste, depois com a casa Gama e Beta à leste do kalderim. 


\section{Casa Zeta Alfa}

A casa Zeta Alfa tem um plano retangular, 23,00 m de leste a oeste e 20,00 m de norte a sul. Sua perpendicularidade é bastante rigorosa. $\mathrm{O}$ muro meridional, que esta à beira da praça de kalderim, é bastante nítido. Não existe nenhuma elevação da casa Zeta Alfa, somente as linhas das paredes no chão. $\mathrm{O}$ exterior desse muro é formado por grandes blocos de sideropetra, aparentemente talhados e o seu interior é de pequenas rochas. Sua entrada se encontra na fachada mais larga da casa e aberta para a praça. A casa Zeta Alfa pertence ao período neopalacial (DEMARGNE e SANTERRE, 1921-48, p.63-79).

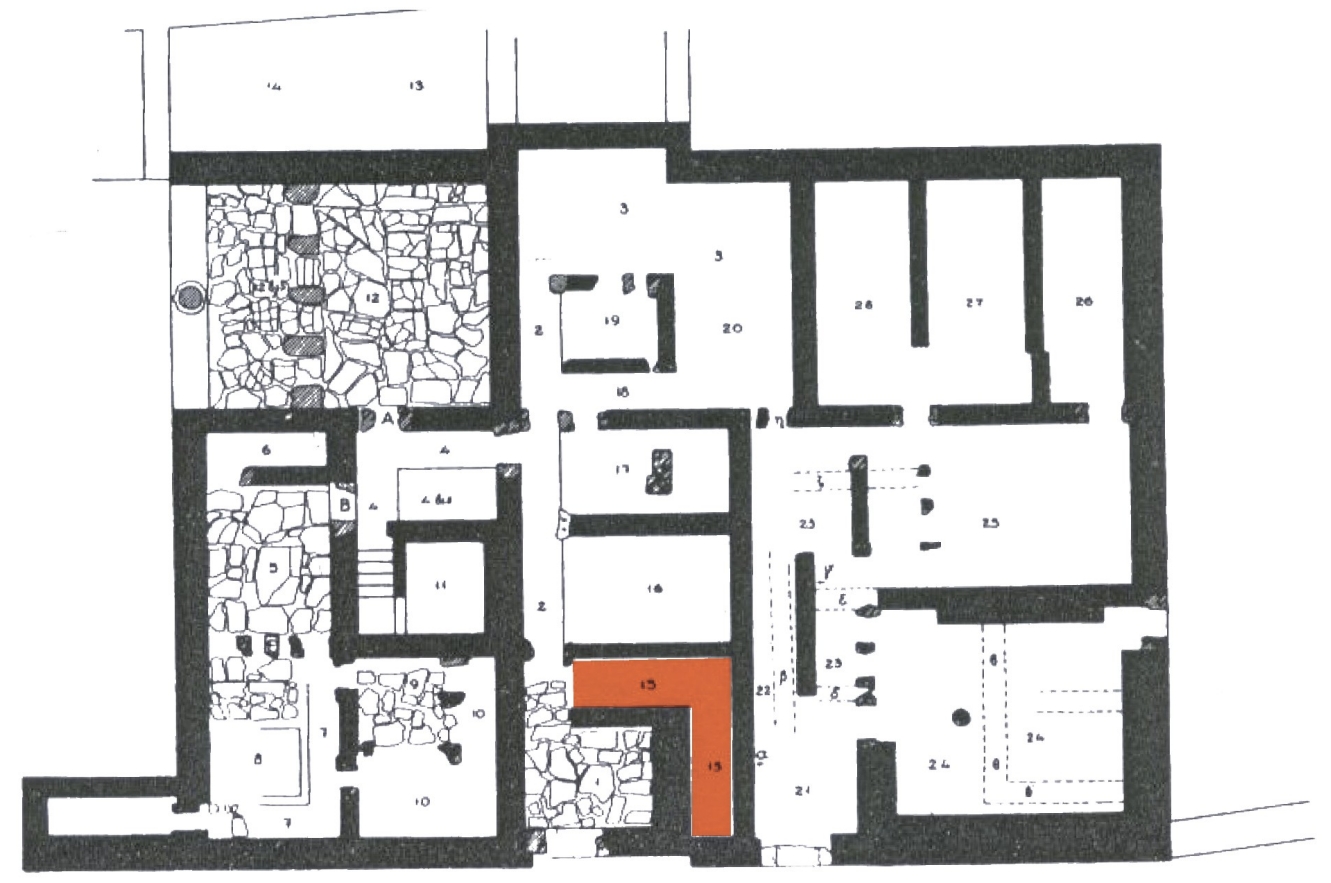

LXVI). E localização da escadaria. 
Na parede norte é muito provável que existisse uma casa contígua e distinta dela.

Existem duas entradas na mesma fachada: uma entrada à direita que possuía uma porta, pois foi encontrada uma soleira com cavidades, muito conhecida na Grécia da época clássica e comum em Mália desde o período protopalacial (EFFENTERRE, 1980, p.150). Essa entrada se abre para a peça 21, um vestíbulo de entrada. Contudo, acredita-se que não fosse a entrada principal da casa. A segunda entrada situa-se na peça 1 e essa seria a entrada principal. A peça 1 leva a um longo corredor central que divide a casa em duas partes, de leste a oeste. No início desse corredor, a oeste, encontra-se uma entrada para a peça 15 , onde foi encontrada grande quantidade de pedriscos. Esse local poderia ter sido ocupado por uma escadaria. Apesar de não possuir evidência direta da escadaria, alguns indícios, como a forma da peça e o fato de conter um muro muito espesso que faz divisa com a peça 1 , no qual a escada se apoiaria, fornecem evidências indiretas para uma escadaria tipo $\mathbf{L}$, que conectaria o pavimento térreo para o superior, primeiramente sugerido por Deshayes e Dessenne (1948-54, p.63-79).

É possível que tenha havido uma ampliação da casa para leste, o que explicaria a disposição não usual das duas portas na fachada principal. Mas essa transformação não deixou nenhum traço e o plano do conjunto se apresenta agora como um todo organizado e coerente (ALLEGRETTE, 1997, p.46).

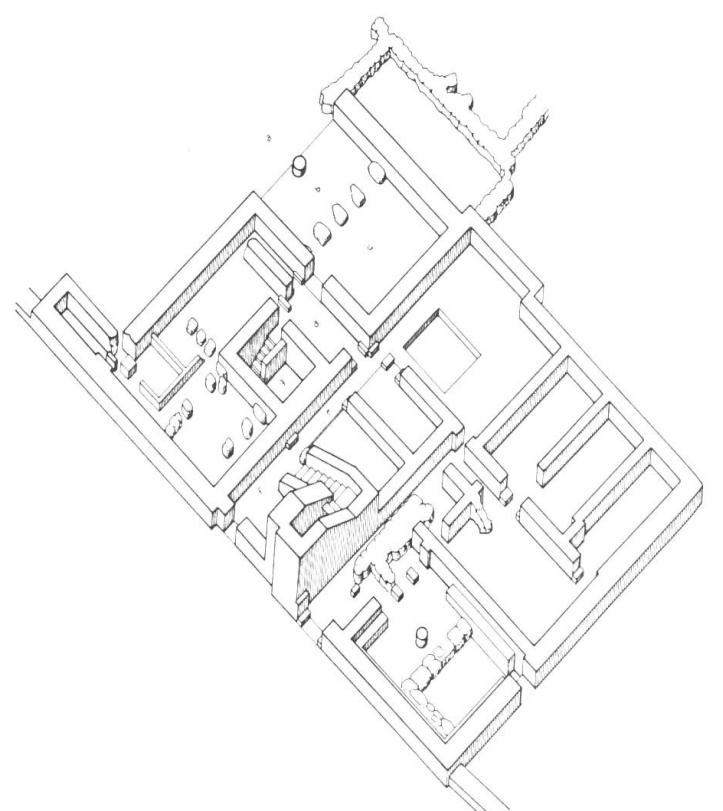

Fig. 39: Perspectiva interna da casa Zeta Alfa, segundo Presiozi (1983, fig. I.13). 
Ao longo daquele corredor existem outras salas, identificadas nas áreas ao leste como ateliês, e nas áreas ao oeste: sala para depósitos, uma sala lustral e um polythyron.

Essa escadaria tem acesso fácil e visível para aqueles que entram na casa pela entrada principal. Ela se situa em um espaço próprio, sem necessidade de invadir alguma sala da residência e mostra também um uso particular e restrito aos moradores. Existe ainda uma possibilidade inversa de uso, já que o pavimento térreo era mais restrito. Talvez fosse esse o motivo para que a escadaria se localizasse bem na entrada da residência.

É muito provável que seu material de construção fosse todo de madeira e elaborada nas técnicas básicas de uma escada leve.

Essa escadaria se encaixa nos elementos configuradores: de fachada e de conexão. 


\section{Casa Zeta Beta}

A casa Zeta Beta que situa mais adiante da Alfa, do lado oposto do kalderim, possui um traçado poligonal excêntrico no seu setor sul (ALLEGRETTE, 1997, p.27).

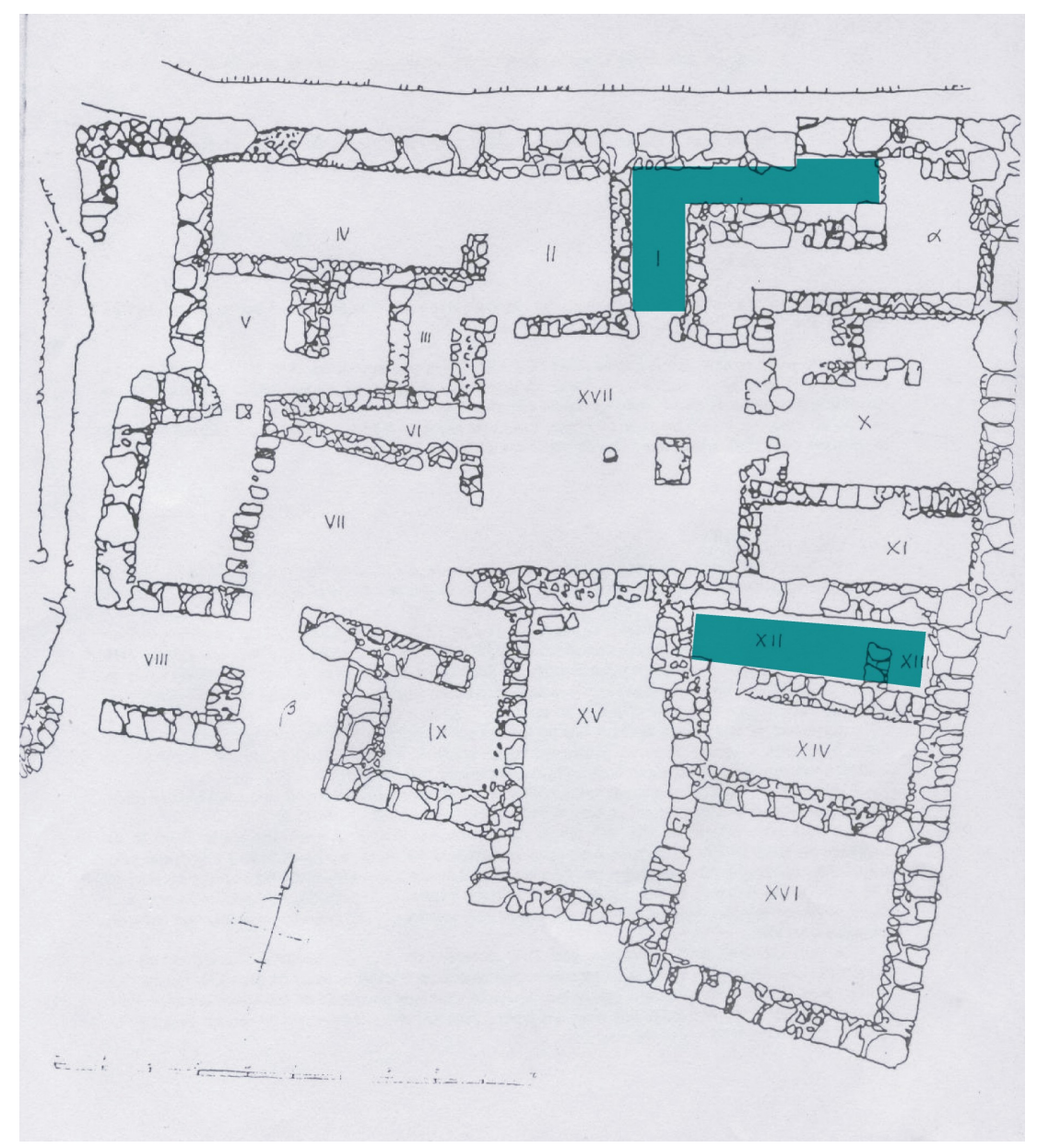

Fig. 40: Casa Zeta beta (DESHAYES e DESSENNE, 1948-54, pl. II) e localização das escadas.

A casa Beta possui duas etapas de construção (DESHAYES e DESSENNE, 194854, p.9). Parte da habitação apresenta traços do período protopalacial, especificamente do Minóico Antigo III , sendo que todo o conjunto foi destruído no fim do Minóico Médio I, 
seguido de uma nova reconstrução que teve lugar no Minóico Médio III B (ALLEGRETTE, 1997, p.27).

A fachada norte, do kalderim, possui 18,70 m, assim como a fachada à leste, onde se situa entrada principal, a. Quanto à fachada sul, ela é reentrante, possuindo uma entrada secundária, b. Do lado oeste a fachada é menor, com limites no pequeno pátio e na casa Zeta Gama.

Alguns pesquisadores acreditam que em sua reconstrução houvesse um ajuste da fachada, por causa disso o alinhamento interno foi alterado ao sul ou ocorreu uma reorientação do traçado da habitação (ALLEGRETTE, 1997, p. 27).

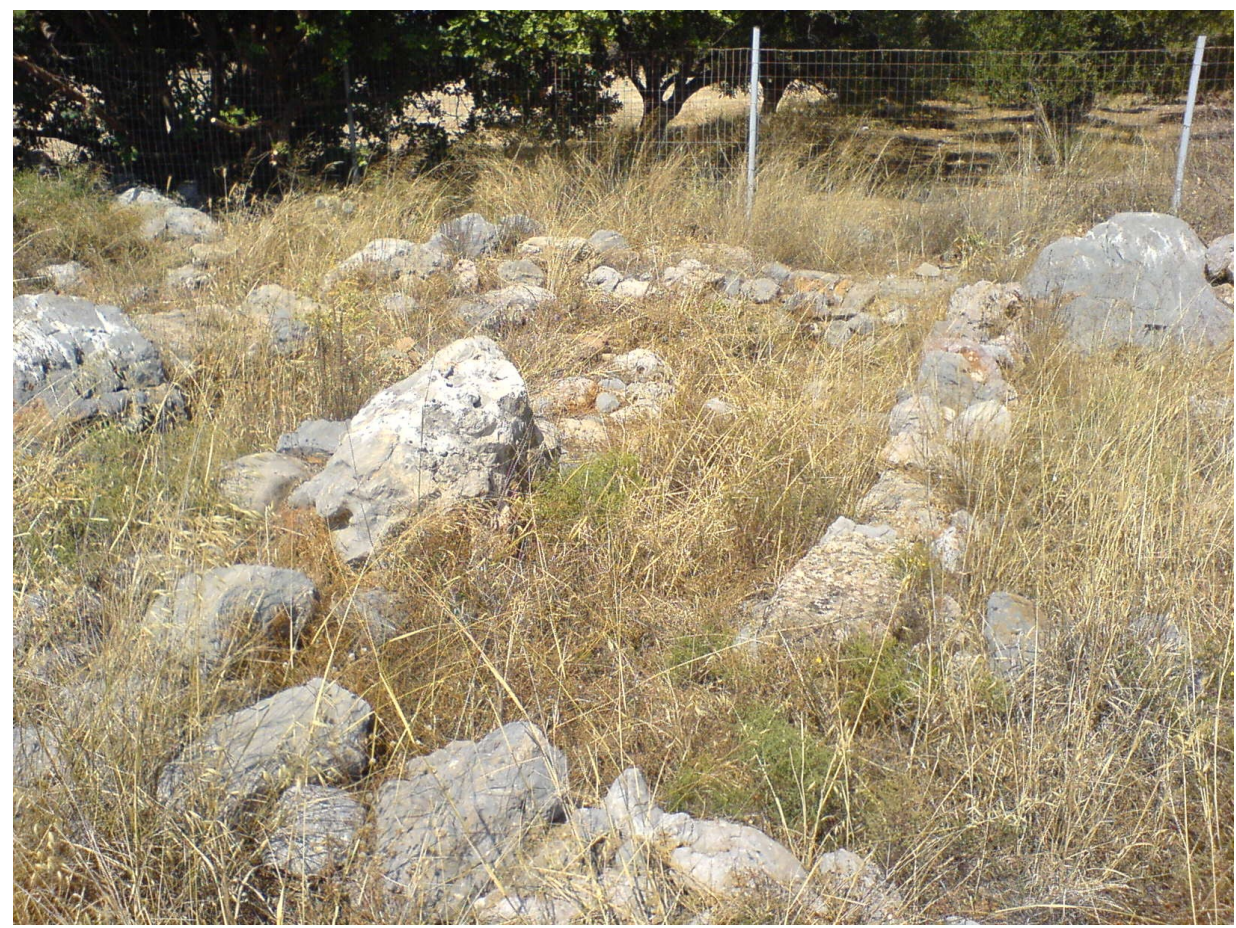

Fig. 41: Foto do área I, Zeta Beta, mostrando o corredor e vão da escadaria.

A partir da entrada principal a, encontram-se duas peças paralelas, a partir das quais atualmente se tem acesso ao interior da casa. Contudo, uma conduz para o pavimento térreo e a outra, área 1, se destinaria a uma possível escadaria para o pavimento superior, 
cujos degraus provavelmente foram construídos de madeira em dois lances, na forma $\mathbf{L}$. De acordo com Deshayes e Dessenne, supõe-se que a profundidade média dos degraus seria de 32 a $35 \mathrm{~cm}$, sendo que a escadaria possuiria um total de doze degraus (DESHAYES e DESSENNE, 1948-54, p.63-79), com cerca de $12 \mathrm{~cm}$ a $15 \mathrm{~cm}$ de altura para cada degrau. As duas peças paralelas são separadas por um muro consideravelmente espesso $(1,04 \mathrm{~m})$, feito com grosso blocos de sideropetra, parecido com a outra parte do edifício mais recente. Portanto, sua construção teria tomado lugar na reconstrução.

$\mathrm{O}$ acesso à escadaria se daria pela entrada a, enquanto que pela sala XVII daria diante a um armário, debaixo da escadaria, não desperdiçando assim o espaço útil da casa (DESHAYES e DESSENNE, 1948-54, p.14; GRAHAM, 1962, p. 66).

A partir do corredor de acesso ao interior da casa, desembocamos em uma sala central da residência, XVII. Sem contar esse acesso inicial, a sala tem aberturas para as áreas X, VII (megaron), VI e II (que seriam aposentos para depósitos ou ateliês, inclusive os espaços III, IV e V). Na área XII caracterizou-se uma cozinha, pelos primeiros pesquisadores (DESHAYES e DESSENNE, 1948-54, p.25). Os vestígios sugerem uma cozinha, a não ser que as cinzas tenham caído do andar de cima (GRAHAM, 1962p. 66).

Três espaços não são acessiveis pelo térreo, as salas XII e XIII e a XIV. Para completar o acesso a sala XIV, deveria existir uma escadaria cujo poço ficaria nas áreas XII e XIII, que possuem entre elas um muro que se apóia na parede sul, mas fica a $40 \mathrm{~cm}$ da parede norte. Esse vão possui 6,00 m de comprimento e 1,20 de largura, espaço suficiente para um escadaria tipo $\mathbf{I}$.

Suas configurações não são somente as de fachadas e conexões mas parece que a mais importante nesse caso seria a de função. E principalmente em espaços estritamente restritos (salas XII, XIII e XIV), isso acontece também no palácio. 


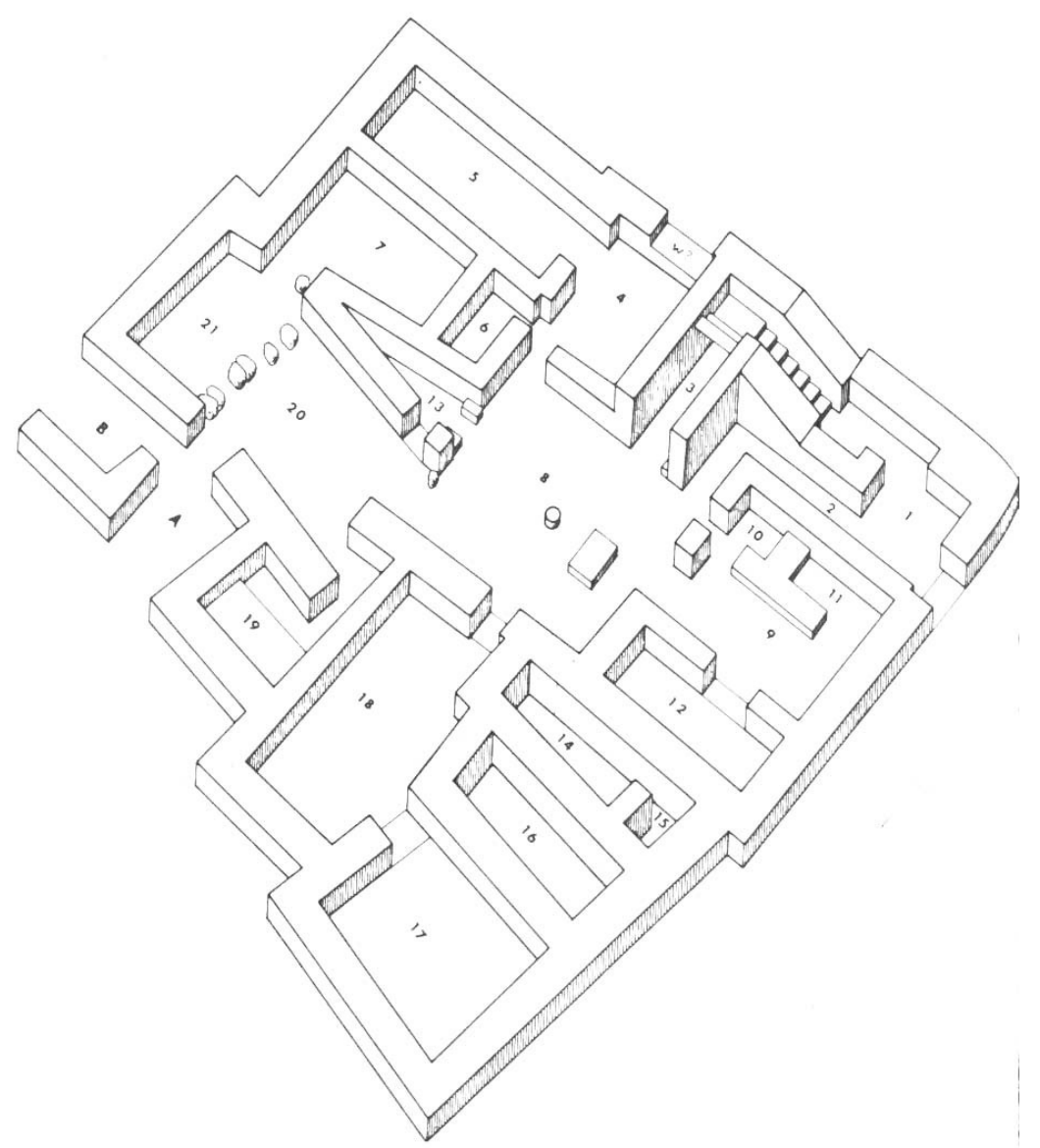

Fig. 42: Perspectiva interna da casa Zeta Beta, segundo Presiozi (1983, fig. II.1.6). 


\section{Quadra Delta}

Do lado extremo oeste do palácio, pela porta noroeste encontra-se uma outra via de ammouda bem conservada em direção à praia. Similar à quadra Zeta, a 35,00 m de comprimento, depara-se em um muro de uma das residências da quadra Delta. Encontraram três residências na quadra Delta: Alfa, Beta e Gama. Nesta última a planta não é bem visível e atualmente todo o lado sul da quadra está abaixo do novo edifício da Escola Francesa, o que impossibilita o estudo da casa Delta Gama.

A parede diante desse caminho, a partir das residências, é de sideropetra grosseira desbastada, mantendo uma altura média de 1,00 m em relação à via. $\mathrm{O}$ nível é mais elevado no início da casa Delta Beta, enquanto no final (onde encontra-se uma curva ao norte e a casa Delta Alfa) é mais baixo.

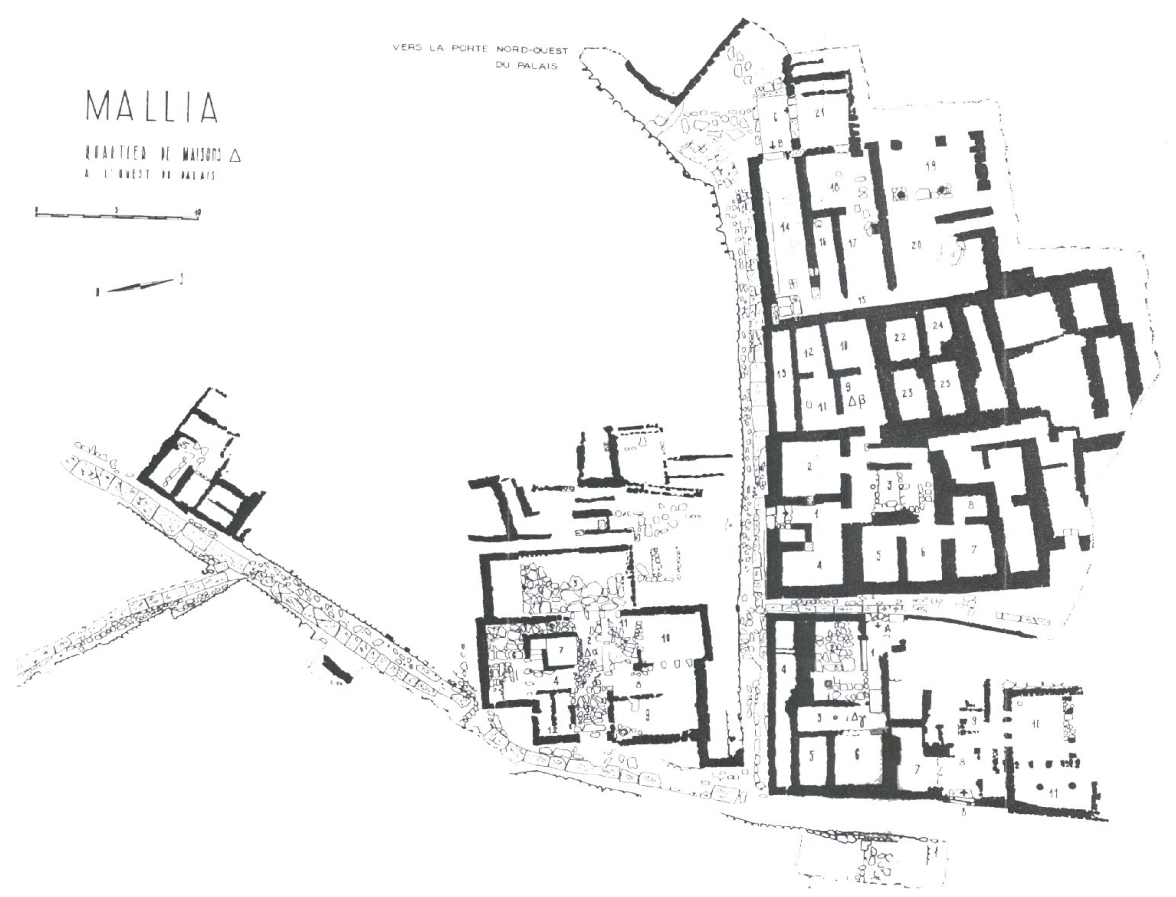

Fig. 43: Quadra Delta (DEMARGNE e SANTERRE, 1921-48, pl. LXVII). 


\section{Casa Delta Beta}

A casa Delta Beta é a primeira residência, situada a leste do caminho de ammouda, do palácio em direção à praia. Inicialmente foi identificada como uma só residência, contudo, a construção se mostra mais como um conjunto que possui 3 blocos distintos (leste, oeste e central), cada um com sua entrada própria, $\mathbf{a}, \mathbf{b}$ e c.

Logo após o caminho existe um vestíbulo que possuía duas entradas, b e c. A entrada c liga diretamente à sala 21 que conecta as salas 18,17 e ao corredor 15,que liga às peças 20 e 19. Esse seria o bloco leste.

Enquanto para o bloco central sua entrada é a b, dá-se ao corredor 14, que liga ao extremo norte do corredor 15 que conecta a uma peça, 16, cuja dimensões são de $1,20 \mathrm{~m}$ de largura e 5,5 m de comprimento, paralelo ao corredor 14. No final do corredor 15 existe também uma passagem de $0,75 \mathrm{~m}$ para o restante do mesmo que dá acesso às outras salas (17 e 20) do bloco leste. Contudo, o corredor 15 é uma divisão entres os blocos, leste e central e acredito que sua função não seria de interligar os espaços 14, 16, 17, 20.

A peça 16 possui dimensões compatíveis para uma escadaria tipo I. Essa escadaria teria degraus de cerca de $0,30 \mathrm{~m}$ de largura e $0,18 \mathrm{~m}$ de altura, possuindo no total 18 degraus que romperia uma altura entre pavimentos de 3,00 m. Essa possibilidade também esta ligada às saliências na área 17 , paralela à peça.

Seu acesso seria somente através do corredor 14 da entrada b. Seria uma escadaria com espaço próprio e restrita do restante do bloco leste. Isso significa que sua conexão seria somente para a área central a casa Delta Beta. Portanto, o bloco leste possui somente um pavimento térreo. E seu provável pavimento superior pertenceria ao bloco central. 


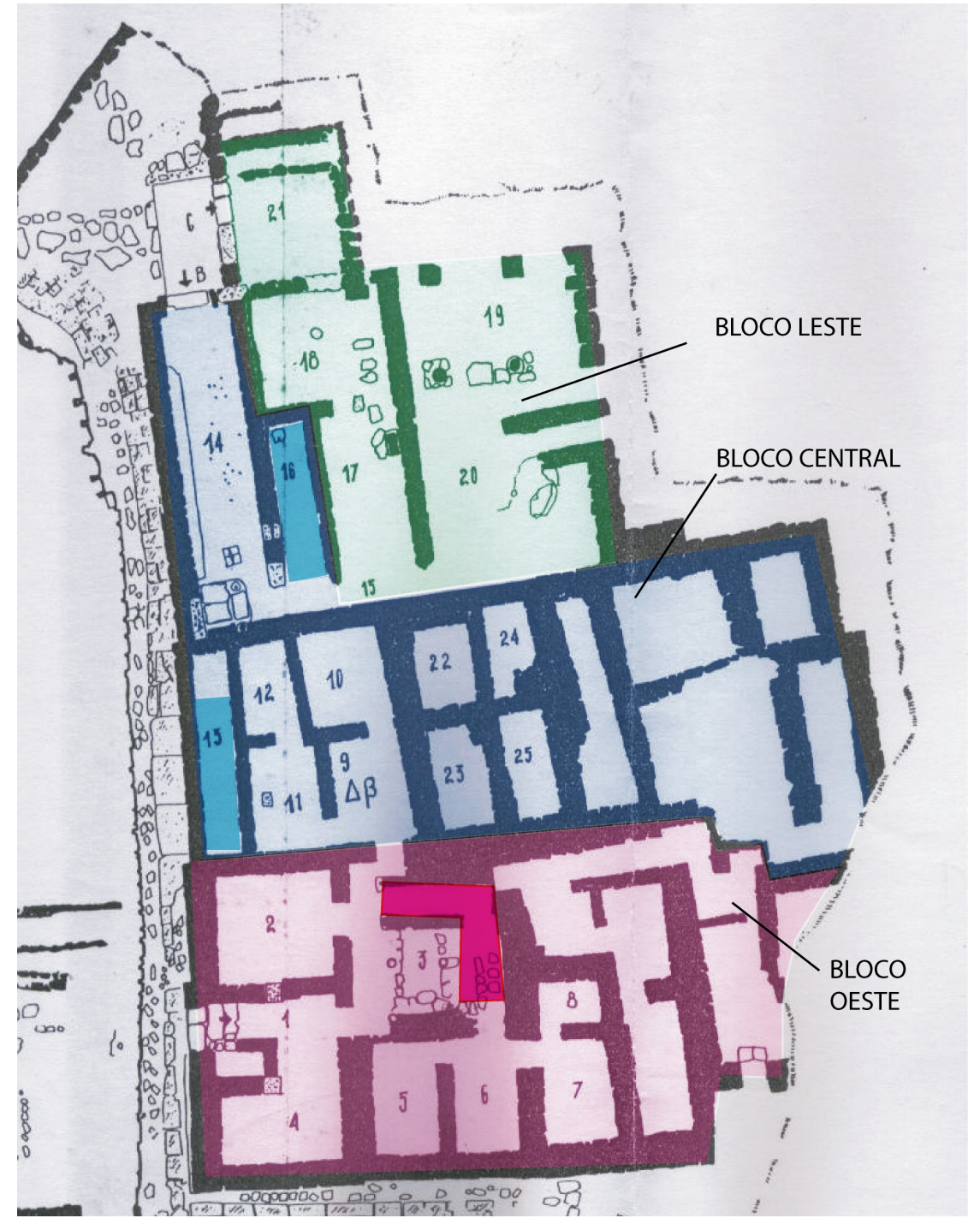

Fig. 44: Casa Delta Beta mostrando os blocos e localização das escadarias (DEMARGNE E SANTERRE, 1921-48, pl. LXV). 
No bloco central, os pesquisadores Demargne e Santerre apontaram no corredor 13 o local para um escadaria (DEMARGNE E SANTERRE, 1921-48, p.51) e seu acesso seria através da área 2 do bloco oeste. Uma escadaria tipo I, no entanto, não possui evidência direta. Contudo, esse corredor, cuja dimensões possibilitam uma escadaria como da área 16 5,5 m de comprimento e 1,00 m de largura, poderia fazer a conexão do pavimento superior para as áreas 12, 11, 9 e 10, mas não pela área 2. A primeira possibilidade seria que o acesso fosse somente através do piso superior, e a escadaria descendente para essas áreas. Possuiria um patamar no seu início a oeste e desembocaria na peça 12. Uma outra possibilidade seria uma ligação através do corredor 14 que a partir dessa área desembocaria a sul para a sala 12, com alguns degraus de desnível e seguindo ao corredor 13 uma escadaria comunicando ao

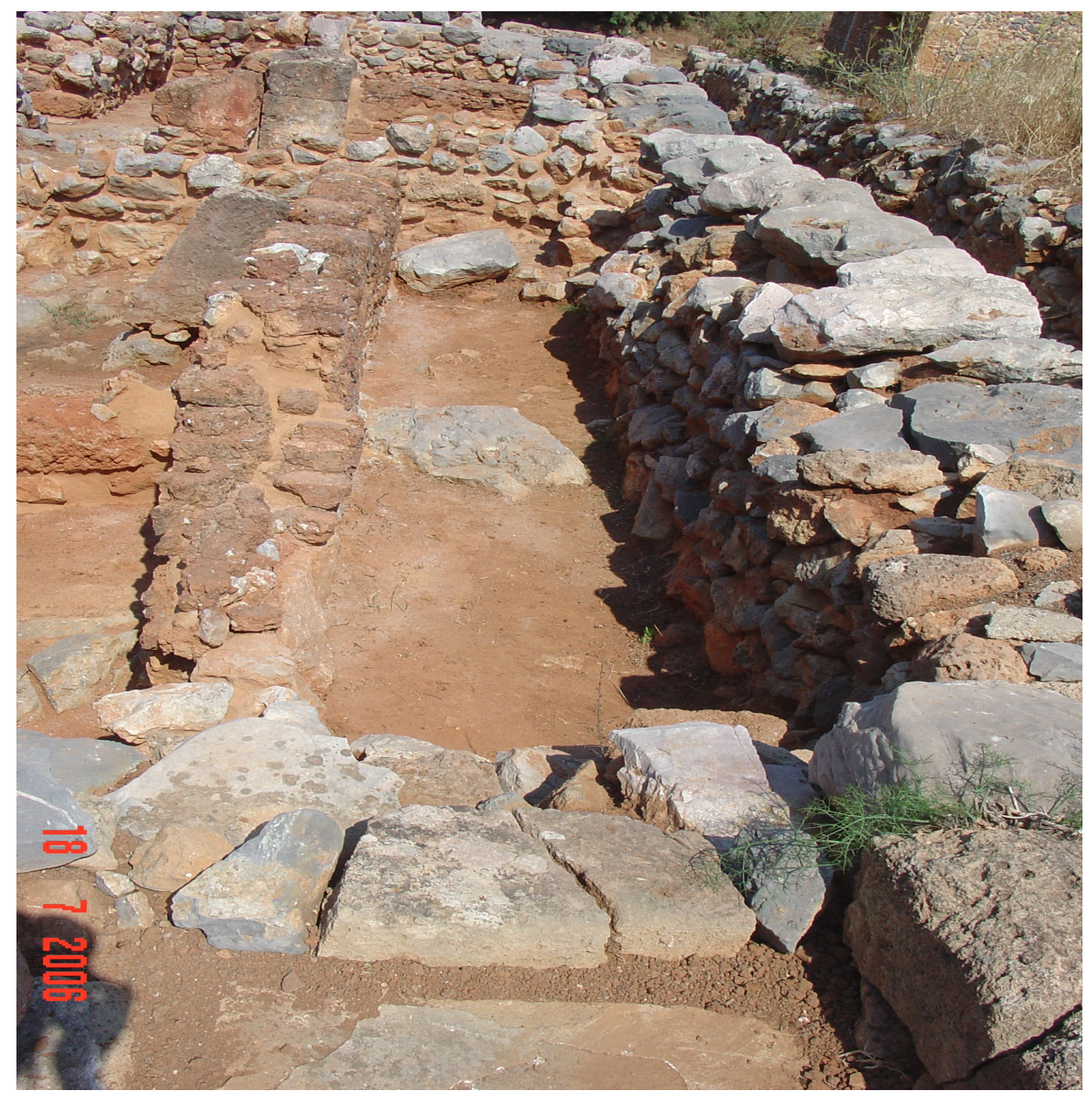

Fig. 45: Peça 13, vão da escadaria do bloco central, casa Delta Beta. 
piso superior. Entretanto, o bloco central teria três entradas a partir do corredor 14, onde duas ligariam ao pavimento superior e uma ao nível das salas 12,11,9 e 10 .

A primeira possibilidade é plausivel porque uma serviria de acesso à entrada (16) e a outra somente para conectar as áreas $12,11,9$ e 10, que serviriam de áreas mais restritas do que a do pavimento superior.

Já o pesquisador Van Effenterre acredita que a residência Beta seria duas casas distintas. E não vê ligação do poço 13 com uma escadaria, criticando assim os primeiros pesquisadores, Demargne e Santerre (EFFENTERRE, 1980, p.414).

Quanto às peças 22 a 25 serviriam, no pavimento térreo, somente de sustentação para o nível superior. Uma outra evidência muito clara que sustenta a suposição de um pavimento superior são as espessas paredes das peças 1 a 13 e 22 a 25.

A estrutura possui também base para apoiar um terceiro pavimento que seria um terraço. Contudo não é possível saber de onde partiria a escadaria para esse acesso ao terraço.

Seguindo a via a oeste encontra-se no mesmo conjunto a entrada a para o bloco oeste. No seu interior encontram-se no vestíbulo 1 e uma pequena célula a oeste desse vestíbulo que os pesquisadores Demargne e Santerre sugerem ser um poço de escada, pouco provável pelas suas dimensões - 1,5 m de comprimento por $0,75 \mathrm{~m}$ de largura, ou um jardim (1921-48, p. 48). Através do vestíbulo 1 liga-se para a sala 4 e a área central do bloco oeste que talvez fosse um poço de iluminação, 3. Dessa área central que se comunica para o restante das salas, 2, 5-8 e um corredor paralelo ao leste. Nesse corredor foi identificado muito carvão, talvez dos degraus de uma escadaria. Como também uma extrema abundância de carvões encontrados nas salas 5 - 7. Para a salas 7 e 8 Demargne e Santerre acreditam que foram usadas como oficinas (DEMARGNE E SANTERRE, 1921-48, p.50). 
A escadaria do corredor paralelo à peça 3 seria tipo $\mathbf{L}$, onde o primeiro lance seria no corredor, apoiando-se na espessa parede da sala 23 (bloco central) e o segundo lance continuaria para oeste se apoiando numa outra espessa parede entre a sala 8.

As paredes do bloco oeste manifestam um excelente suporte para um segundo andar, inclusive se observarmos os dois pilares, um se encontra entre o vestíbulo 1 e a sala 2 e o outro na esquina do "jardim" e a sala 4.

Além disso, existe uma passagem do bloco oeste para o central na peça 9 e perto do corredor do poço da escadaria, essa comunicação possui dimensões de $0,75 \mathrm{~m}$ de largura, exatamente as mesmas do corredor 15 entre o bloco leste e a entrada do bloco central. Contudo, essas passagens são muito estreitas para uma residência desse tamanho. Por causa dessas passagens que questionaram e ainda são questionadas a unidade da Casa Delta Beta. 


\section{Casa Delta Alfa}

A casa Delta Alfa é mais simples, melhor conservada e bem delimitada e possui por volta de $170 \mathrm{~m}^{2}$. Sua entrada principal situa-se no centro da fachada ao longo da continuação da via principal a norte. Possui uma fachada sinuosa que acompanha o trajeto da rua $^{15}$. A peça 1 , entrada, e a peça 2 abrem-se para dois compartimentos desiguais da residência, para sul estão as peças 8,910 e 11 . A peça 8 é um corredor entre as salas 9 e 10 , e a área 11 parece mais uma peça isolada. Para os pesquisadores Demarge e Santerre, a sala 9 tinha uma finalidade de oficina, porque lá foram encontradas panelas, ânforas e jarros em grande quantidade (DEMARGNE E SANTERRE, 1921-48, p. 70). Na sala 10, foi encontrado um vaso datado da época MM III, paralela a essa peça, entre a 11, existe uma pequena escada com três degraus conservados de pedra maciça na área 11. Os pesquisadores acreditam que possuiria uma escadaria que conectaria ao pavimento superior, sendo o restante da sua construção em madeira. Contudo, mais parece uma escada de desnivelamento. Ela é mal localizada para possuir uma escadaria de por volta 12 a 15 degraus. É muito provavel que fosse uma escadaria de desnível ligando as peças 11 e 10. Além de ser o único caso de uma escadaria não possuir um lugar próprio e em ângulo (isso é excepcional na arquitetura maliota).

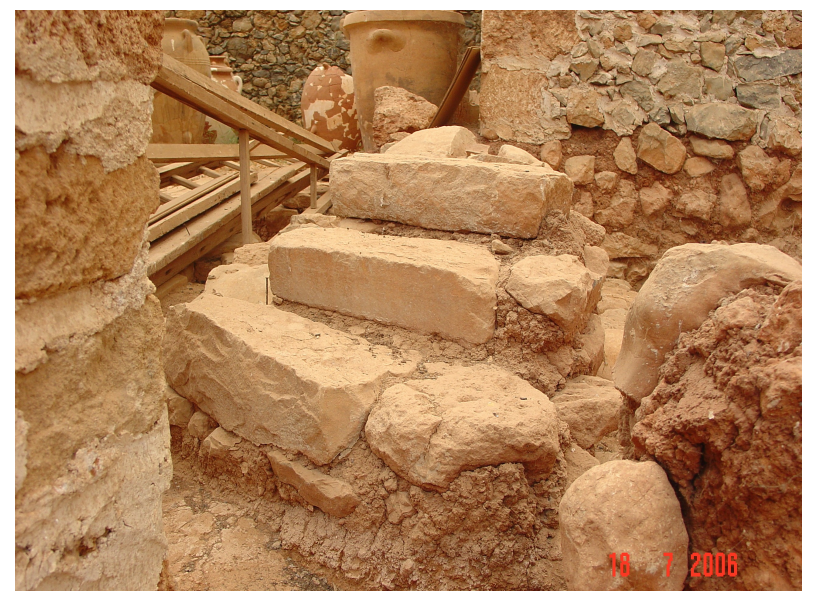

Fig. 46: Degraus in loco entre as peças 10 e 11, casa Delta Alfa.

15 Essa fachada sinuosa que encontra-se também nas outras faces do edifício, pode ser compreendida como um dispositivo anti-sísmico. 
No restante da residência, no centro ao fundo, dá-se para um megaron, sala 3. E no outro lado, norte, existem as peças 4, 5, 6 e 7. As áreas 4 e 5 são corredores por entre a sala lustral, peça 7, e que acessa também para a peça 6 .

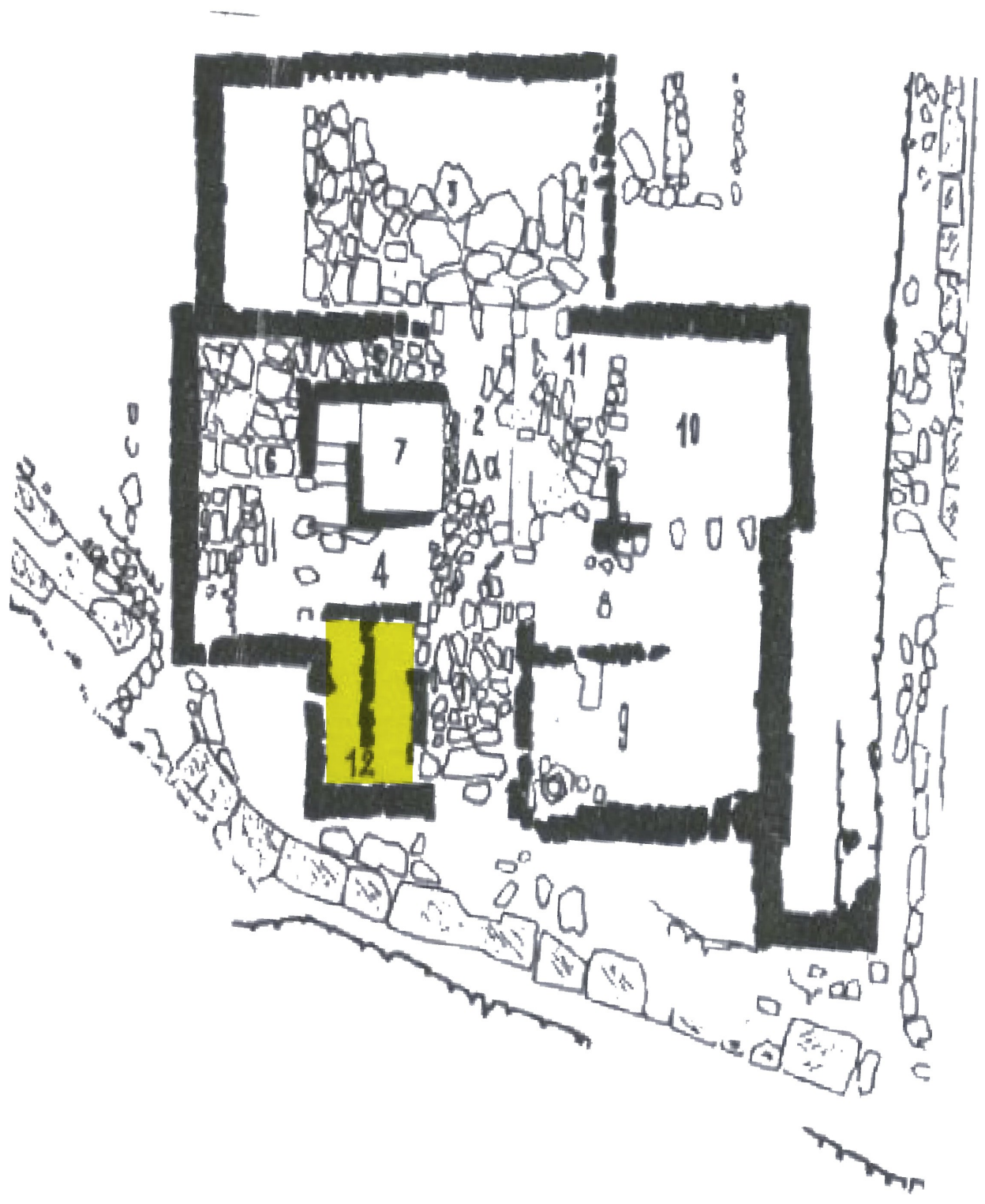

Fig. 47: Casa Delta Alfa e locolização da escadaria 44: Casa Delta Beta mostrando os blocos e localização das escadarias (DEMARGNE E SANTERRE, 1921-48, pl. LXVII). 
No mesmo lado, paralela à área 1 , encontra-se a peça 12 . Essa peça possui $2,70 \mathrm{~m}$ de comprimento por 2,00 m de largura e uma parede no centro. Um perfeito local para um poço de escada, provavelmente seu acesso seria através da peça 1 e possuiria uma porta, já que existe vestígios de soleira no seu acesso. Essa escadaria, de tipo U, serviria para conectar o pavimento térreo ao superior, além desse espaço possuir medidas cabíveis para uma escadaria, ela possui um espaço próprio, muito comum na arquitetura minóica e paredes espessas o suficiente para sustentação.

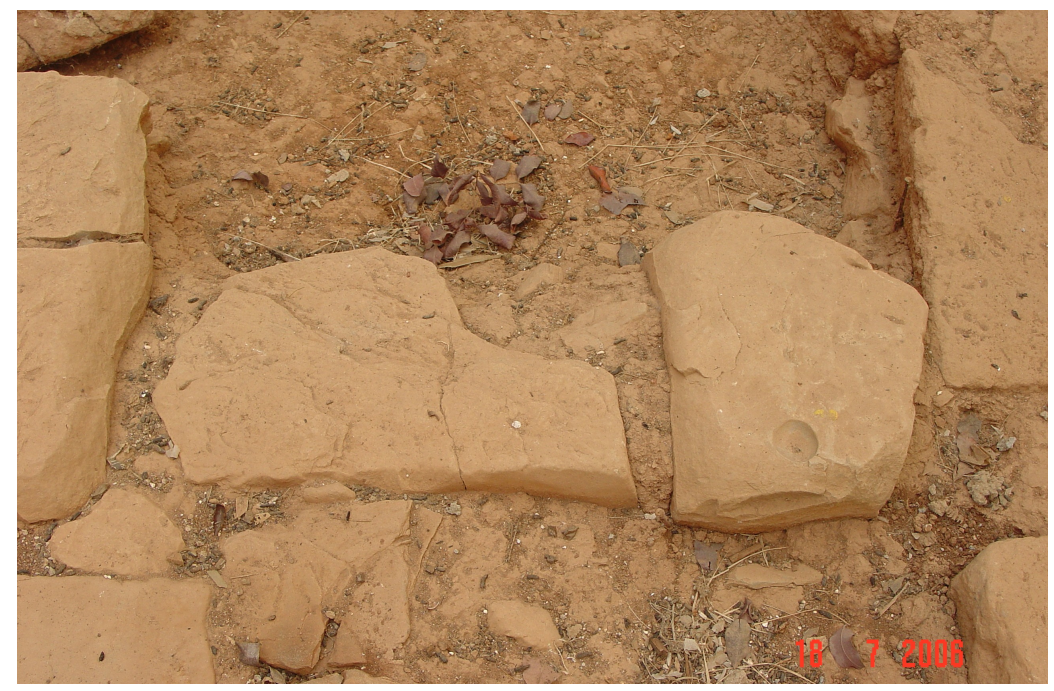

Fig. 48: Soleira na entrada da peça 12, casa Delta Alfa.

Essa escadaria é muito similar à casa Zeta Alfa, tanto sua situação, localização e técnica de construção. É provável que seu material de construção fosse todo de madeira e possuísse técnicas básicas de uma escada leve.

Infelizmente, não possuíamos todas as informações das escavações que nos forneceriam detalhes muito importantes para sugestões das escadarias.

A escadaria se encaixa nos elementos configuradores: de fachada e de conexão. 


\section{Quadra Épsilon}

A quadra Épsilon localiza-se a sul do palácio, seu formato é retangular medindo grosseiramente por volta de 50,00 m (eixo leste-oeste) ao longo da rua, e 28,00 m (eixo nortesul). Assim como todas as quadras analisadas até então, as casas da quadra Épsilon também seguem o traçado da rua. Allegrette afirma que "existe uma rede de ruas organizadas, estreitas e tortuosas, mas com algumas retas" (ALLEGRETTE, 1997, p.18). Esse caminho é feito de placas de ammouda com o kalderim ladeando e as casas seguem o mesmo traçado.

Há vestígios de construção do período protopalacial (Minóico Médio I) e o conjunto dessas estruturas confirma a existência de uma ocupação importante durante o Minóico Médio II em Mália. (ALLEGRETTE, 1997, p.18)

Existe uma grande diferença entre as quadras Zeta e Delta, mas ao mesmo tempo é similar as casas da quadra Mu. As casas da quadra Épsilon são geminadas, aglomeradas uma a outra dificultando seus limites. Portanto analisaremos a única casa delimitada e analisada até hoje. Ela é a maior residência já encontrada em Mália. 


\section{Casa Épsilon}

A entrada da casa fica a noroeste, composta por um degrau de sideropetra $(1,70 \mathrm{~m}$ de largura). Devido a essa impressionante entrada, suas dimensões e sua organização interna, foi inicialmente chamada de 'Petit Palais' (DESHAYES e DESSENNE, 1948-54, p. 94).

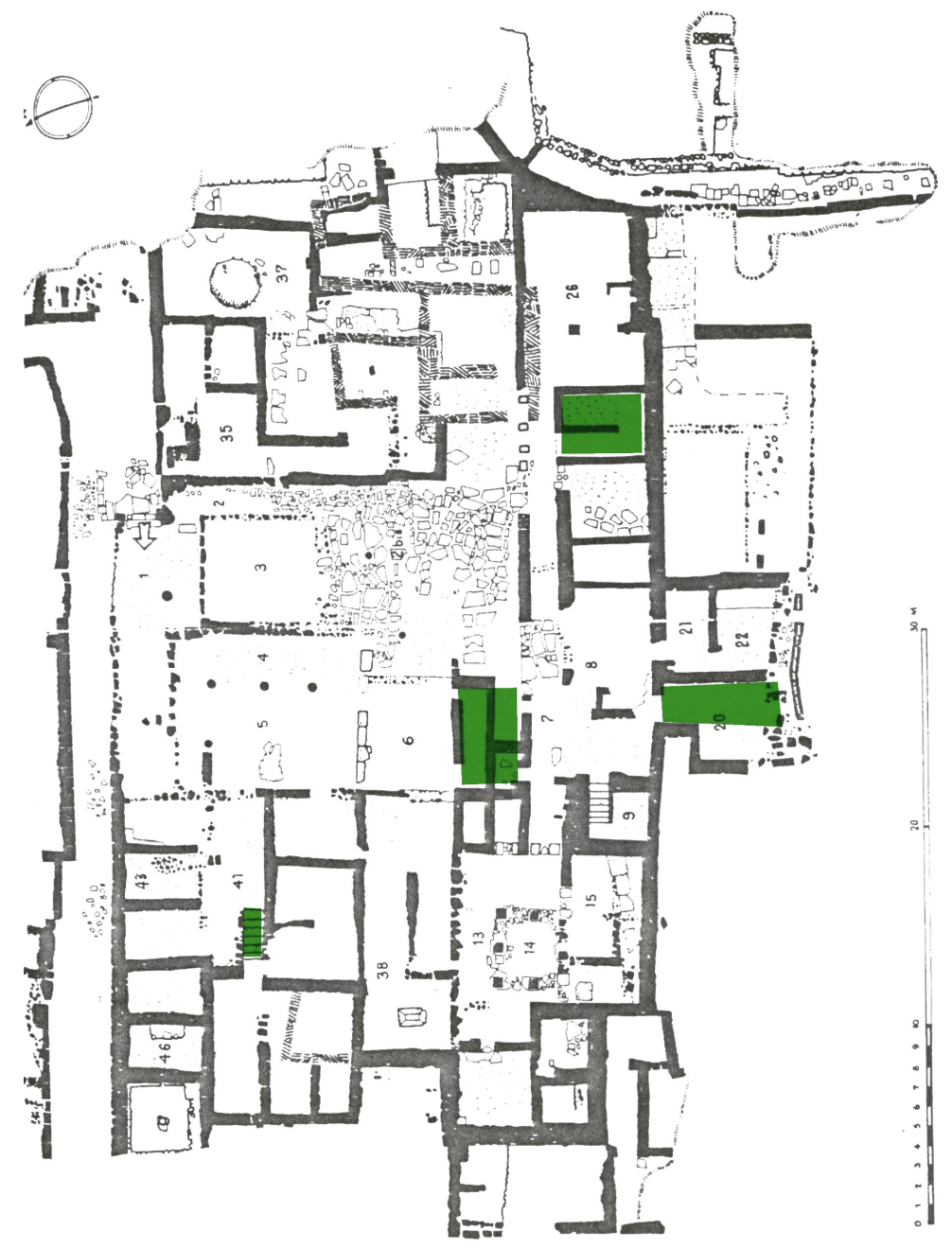

Fig. 49: Planta da casa Épsilon e localização das escadarias (EFFENTERRE, 1980, fig. 553).

A entrada se dá para o vestíbulo 1, um espaço quadrado com uma coluna descentralizada, e a sudoeste existe um corredor que leva a um pátio central pavimentado $2 \mathrm{~b}$ 
com duas colunas. Todo o restante da residência é acessível pelo pátio central.

Ao norte o pátio se abre para a sala 3, de função desconhecida, e a noroeste para uma sala colunada, 4 , que se abre a oeste para a peça 5 e a sudoeste para a peça 6 , separadas daquela por um polythyron agora destruído. Nesta mesmo direção, a oeste da peça 5 e do pátio 2, segue uma série de depósitos distribuídos de maneira irregular num eixo leste-oeste, 43-46, que se ligam pela vestíbulo 41 ao sul destas, e ainda mais ao sul conectadas por um escadaria de desnível, contendo sete degraus, que se comunica com uma outra série de salas, numeradas 39, 40, 47 e 48 .

Já para leste do pátio há um conjunto de salas, 27 - 37, destinadas a atividades de preparação e estocagem de alimentos.

Enquanto isso na ala sul se localiza a área residencial, $7-26$. O pátio 2 se conecta ao corredor 7 que comunica as salas 11 e 12 a noroeste. Nessa mesma face, há uma sala lustral, mais ao sul, marcada como sala 9. Seguindo o corredor 7 a oeste se depara a um pátio com perístilo, em 13 e 14 e um aposento anexo 15 ao sul. Nesta ala Van Effenterre sugere uma escadaria tipo U (citado por ALLEGRETTE, 1997, p.18) onde seu extremo inferior estaria no pátio central 2, seguiria pelo espaço definido por um muro paralelo ao corredor 7 , que existe na parte sul da área 6, se prolongaria em um pequeno espaço paralelo a 11 e ascenderia sobre as peças 11 e 12 , com paredes que sustentariam a escadaria.

$\mathrm{Na}$ área central da ala sul encontram-se as peças 8, 20-22 de função desconhecida. No extremo sul dessa área temos a peça 20 que talvez possuísse uma entrada secundária que seria através de uma escadaria, tipo I. O nível vizinho da quadra Épsilon é bem mais elevado, porém, essa idéia não se apóia em vestígios claros que contribuíssem para suportar essa hipótese. Contudo em construções menores sabemos que poderia haver mais do que uma entrada. Nesse caso, existem três elementos que sustentam essa interpretação: a primeira seria 
pelo tamanho da residência; a segunda, que as fachadas norte, leste e oeste estão bem delimitadas enquanto que a de sul não está; e por último, esse lado da casa é mais restrito, ligando-se diretamente à área residencial.

Já na área leste encontram-se as áreas $23-26$, onde a peça 25 possui uma forma que sugere um poço de escadaria (DESHAYES e DESSENNE, 1948-54, p. 103). O desenho da peça 25 e suas dimensões, $4 \mathrm{~m}$ de comprimento e $1,00 \mathrm{~m}$ de largura na primeira peça e 1,20 $\mathrm{m}$ na segunda, indicam claramente um poço de escada. Essa escada de tipo $\mathbf{U}$ começaria pelo sul do pátio central, contendo um patamar intermediário que se apóia em um pilar de sustentação para a escadaria no extremo da parede central, assim como no muro sul, limite da casa. Seus degraus seriam de madeira, com 12 degraus no primeiro lance e 5 degraus no segundo, mais o patamar intermediário, de acordo com nossos cálculos.

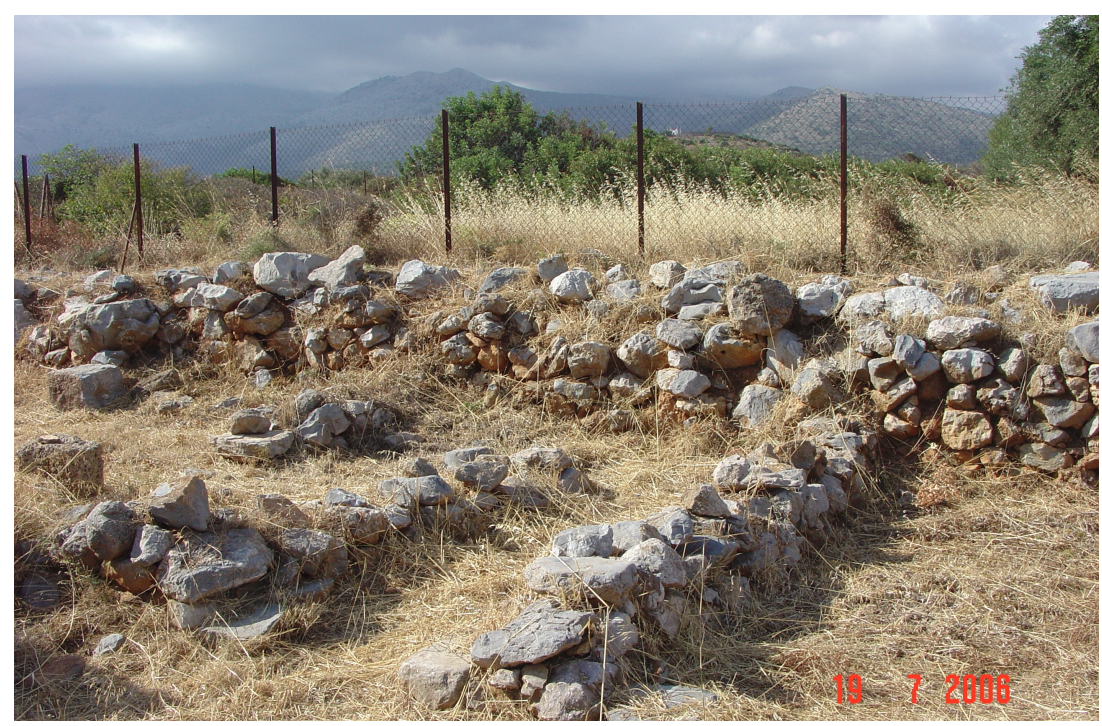

Fig. 50: Poço da escadaria, peça 25, casa Épsilon.

Para a casa Épsilon o segundo pavimento estaria em torno do pátio central, as escadarias não seriaam configuradoras de fachada, pois sua entrada e toda as áreas 1-6 seriam espaços abertos. Certamente se configurariam como de conexão e de função (principalmente em sua entrada secundária). 


\section{Quadra Mu}

A quadra $\mathrm{Mu}$ situa-se a noroeste da quadra Delta, a $100 \mathrm{~m}$ oeste da Cripta Hipostila e a 300 m, na mesma direção, do palácio. A quadra possui uma área total de 3000 $\mathrm{m} 2$, um aglomerado de casas e oficinas ao longo de ruas sinuosas. Compõe-se de 2 grandes edifícios A e B, de oficinas (Selos, Cerâmica, Fundição, C e Sul), além de outros dois edifícios dos quais não se sabem suas exatas funções, edifícios D e E.

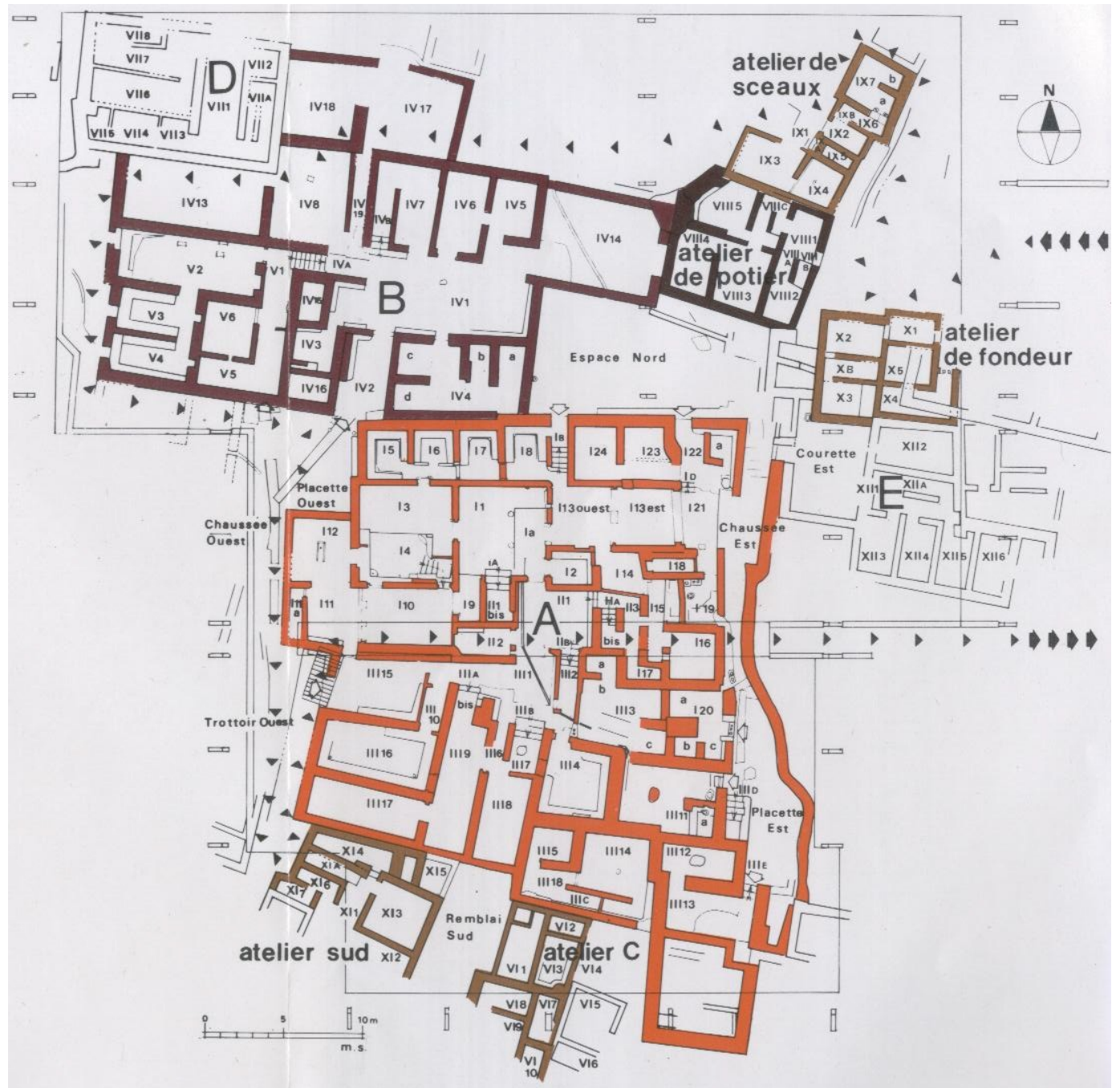

Fig. 51: Quadra Mu (POURSAT, 1996). 
Datada do período dos primeiros palácios, Minóico Médio II é a descoberta mais importante do protopalacial. Ela foi ocupada até sua total destruição no fim desse período. Um imenso incêndio destruiu a quadra, que se preservou devido à sua construção (uma técnica diferente do palácio e das outras construções posteriores) e por não haver reocupação nem recuperação nas épocas seguintes. (POURSAT, 1996, p.11).

Sua descoberta foi em 1956, e escavações anos seguintes, mostram uma arquitetura única, tanto na sua planta regular como na sua técnica. Muros de tijolos cru, estucados com argila e associados com aparelhagem de madeira. Algumas paredes eram estucadas de cores azul ou vermelho. Os efeitos do incêndio foram particularmente impressionantes devido a esse fator técnico de construção, que ao invés de levar à perda das estruturas, provocou a sua conservação. Porém esta conservação foi observada principalmente nas casas A e B, não nas oficinas. Os muros preservados dos edifícios A e B chegam até 1,90 $\mathrm{m}$ de altura. Foram achados objetos intactos e pedaços de pavimento superior. Além disso assinalamos a excelente conservação de algumas escadas, principalmente nos edificios A e B. ( POURSAT, 1996, p.14).

Esta quadra apresenta também alguns elementos arquitetônicos próprios da arquitetura minóica que evidencia sua presença desde o protopalacial: pátio com pórticos, poço de luz, sala lustral subterrâneas, depósito em séries, santuários e as escadas. Não existe pátio central em nenhumas das construções da quadra $\mathrm{Mu}$; para a pesquisadora Palyvou, o pátio central se torna mais evidente para as construções posteriores, devido a centralização de poder no palácio e a partir daí esse elemento arquitetônico é copiado para outras menores. Ela acredita que o espaço da ágora teria essa função na época protopalacial (PALYVOU, 2001, p. 167-177)

As pesquisas seguiram primeiramente em setores ou zonas em letras romanas em 
toda a quadra e depois de identificadas seguiram com letras os edifícios e oficinas. As escadas são identificadas com sua numeração romana e em seguida com letras maiúsculas. 


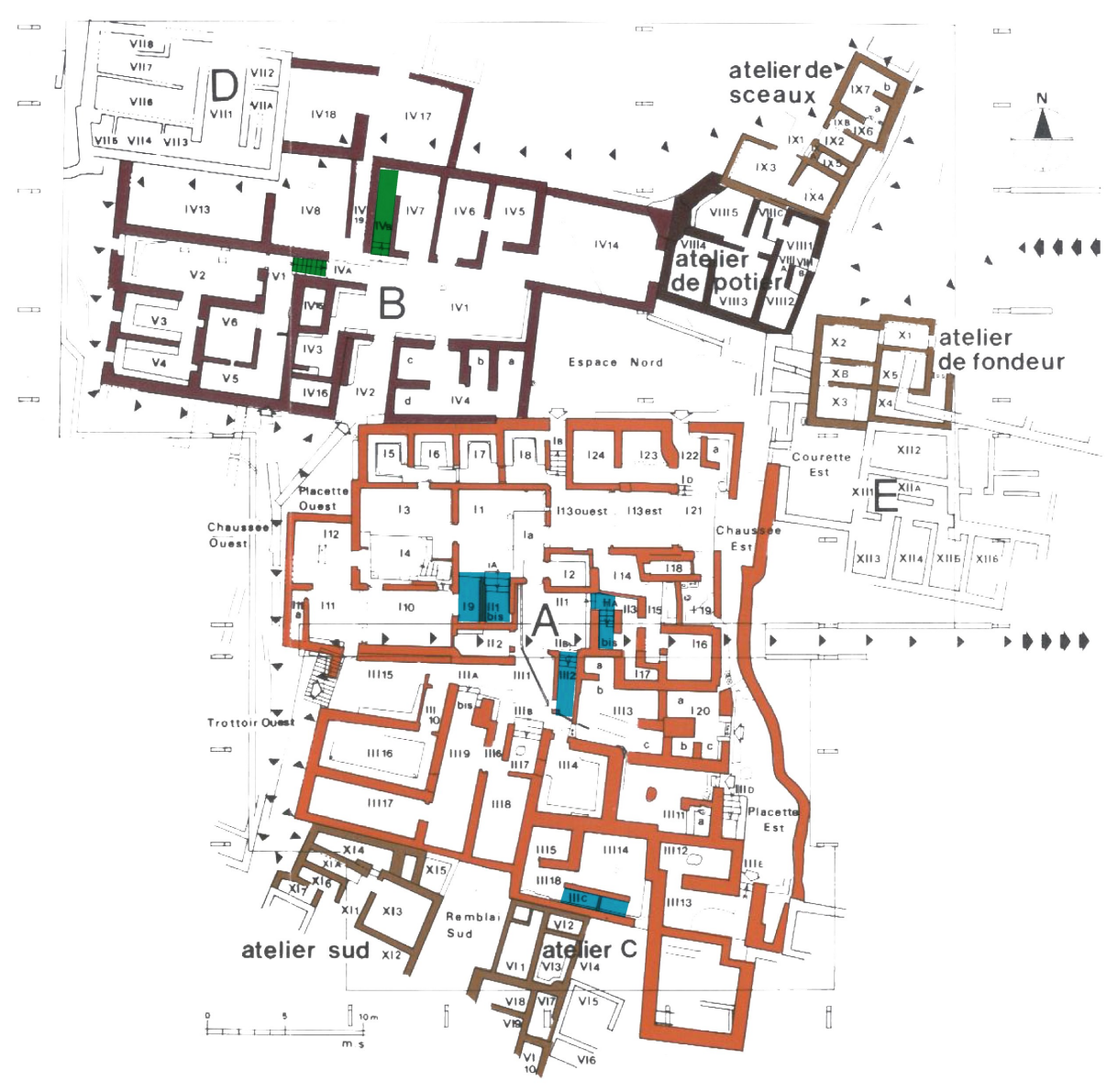

Fig. 52: Quadra Mu, casa Mu A e localização das escadarias (POURSAT, 1996).

A mais importante e maior edificação da quadra $\mathrm{Mu}$, com $840 \mathrm{~m}^{2}$, foi dividida em três setores, I, II e III. Ao norte do edifício possui uma forma regular, linhas retas norte e sul, mas a sul existe uma ligeira diferença da orientação dos muros (sentido às oficinas $\mathrm{C}$ e Sul) concluindo num conjunto um formato trapeziodal, de forma semelhante à casa Zeta Beta. Essa irregularidade explica duas fases de construção. Ao norte é mais antiga que a sul (POURSAT, 1996, p.31). A fachada principal, ao longo da via oeste, apresenta blocos talhados e brutos em 
ammouda, enquanto o restante do edifício as técnicas de construção são paredes e pisos de argila revestidos com estuque colorido, azul e vermelho. Possui uma função polivalente: existe desde santuários, salas de preparo de alimentos, áreas para abrigar animais, e salas de aparatos, armazéns de estoque e foram encontrados documentos escritos, que tendem a indicar um edifício cujo papel teria também um sistema administrativo do sítio (POURSAT, 1996).

A entrada principal fica ao longo da calçada oeste, possui um aspecto monumental e se abre sobre um vasto vestíbulo com bancos nas paredes sul e leste, III 15, ao norte conecta ao setor I, a sul o setor III e a leste o setor II.

A partir da passagem para o setor I ao norte, desemboca imediatamente a ante sala do santuário, I 12, e as peças que provavelmente faziam parte do ritual cerimonial: I 4 sala lustral, I 3 vestíbulo, I 1 pátio com pórticos, e I 13 polytyron. As peças I 11, I 10 e I 9 talvez fizessem parte das peças de aparatos também.

Seguindo a extremo norte existem salas de armazenamento assim como suas duas entradas secundárias a partir do espaço norte. A entrada I B possui uma escadaria de desnível. E no extremo leste se dá a fachada ao longo da calçada leste com espaços destinados a preparo de alimentos e pequenos depósitos.

Do pátio com pórtico, I 1, possui duas saídas ao sul, uma é um corredor que conecta o setor III e o setor central II, e a outra para uma escadaria I A.

A escadaria I A possui quatro degraus com largura de 1,45 m, o primeiro degrau é em sideropetra e o restante estucado, levaria ao segundo pavimento. A área possui 3,00 m de comprimento, onde ficaria o primeiro lance, poderia conter por volta de seis degraus e um patamar de por volta de $1,00 \mathrm{~m}^{2}$, se contarmos com os degraus com altura de $0,30 \mathrm{~m}$. 
Infelizmente não se tem a exata medida dos degraus que estão in loco. Já o segundo lance poderia se estender para a peça 9 , escada tipo $\mathbf{U}$, mas isso significa que a passagem da peça 9 para a sala de aparato 10 teria uma altura não muito elevada, de por volta de $2,10 \mathrm{~m}$, contudo é o suficiente para passagem.

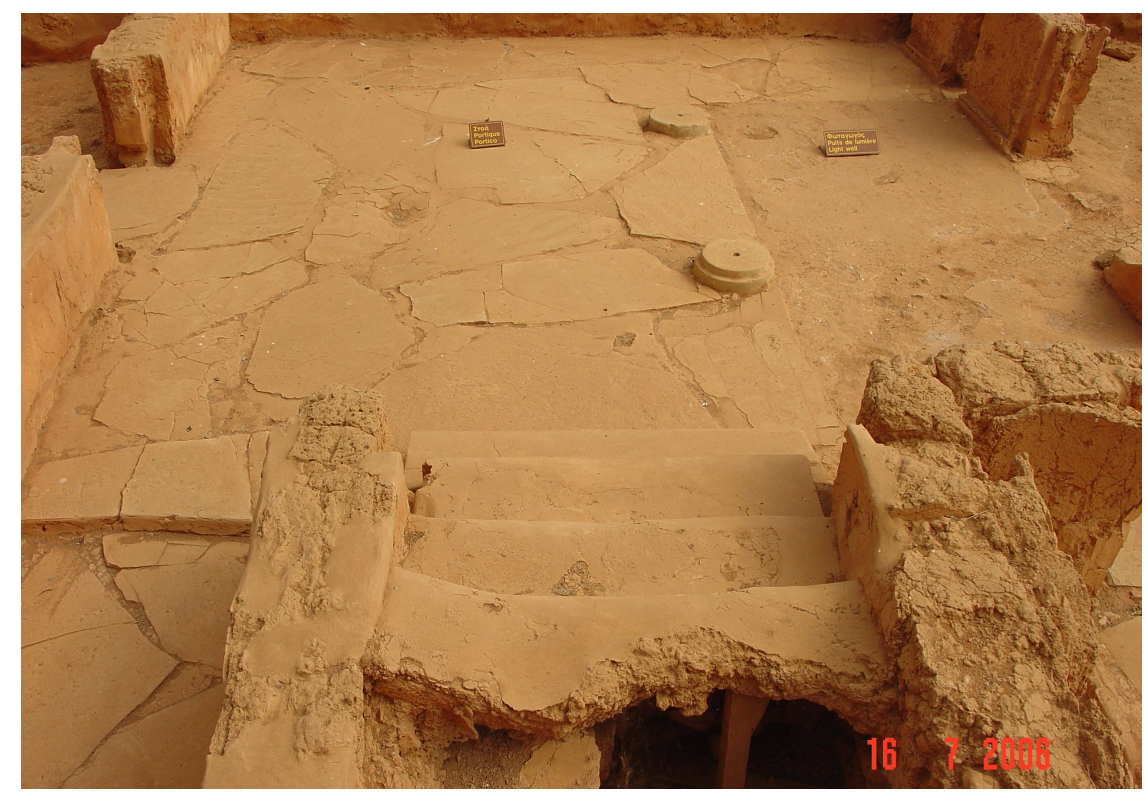

Fig. 53: Escadaria I A com degraus in loco, Casa Mu A.

Em direção ao setor III, que é a extensão do edifício procede imediatamente a dois espaços interiores, o vestíbulo II 1 e ao poço de luz II 2 a oeste. A leste se depara a uma escadaria II A que possui três degraus no seu lance inicial e se estende a sul com mais três degraus in loco. $\mathrm{O}$ espaço do poço é menor do que as outras encontradas no edifício, 2,20 m de comprimento e um pouco menos de 1,00 m de largura, mas ela poderia possuir degraus mais estreitos e uma maior inclinação para romper altura, se configuraria numa escadaria tipo L.

E a sul da peça II 1 se depara o setor III e a uma escadaria II B na área III 2, cujos quatro primeiros degraus estão in loco. A área do poço dessa escadaria é de $4,00 \mathrm{~m}$ de comprimento e $1,00 \mathrm{~m}$ de largura. Novamente, não possuímos as medidas para o cálculo do 
restante da escadaria, e seria tipo I. É possível que esse fosse o acesso para o pavimento superior para esse bloco, III, hipótese apoiada pelas paredes espessas desse setor.

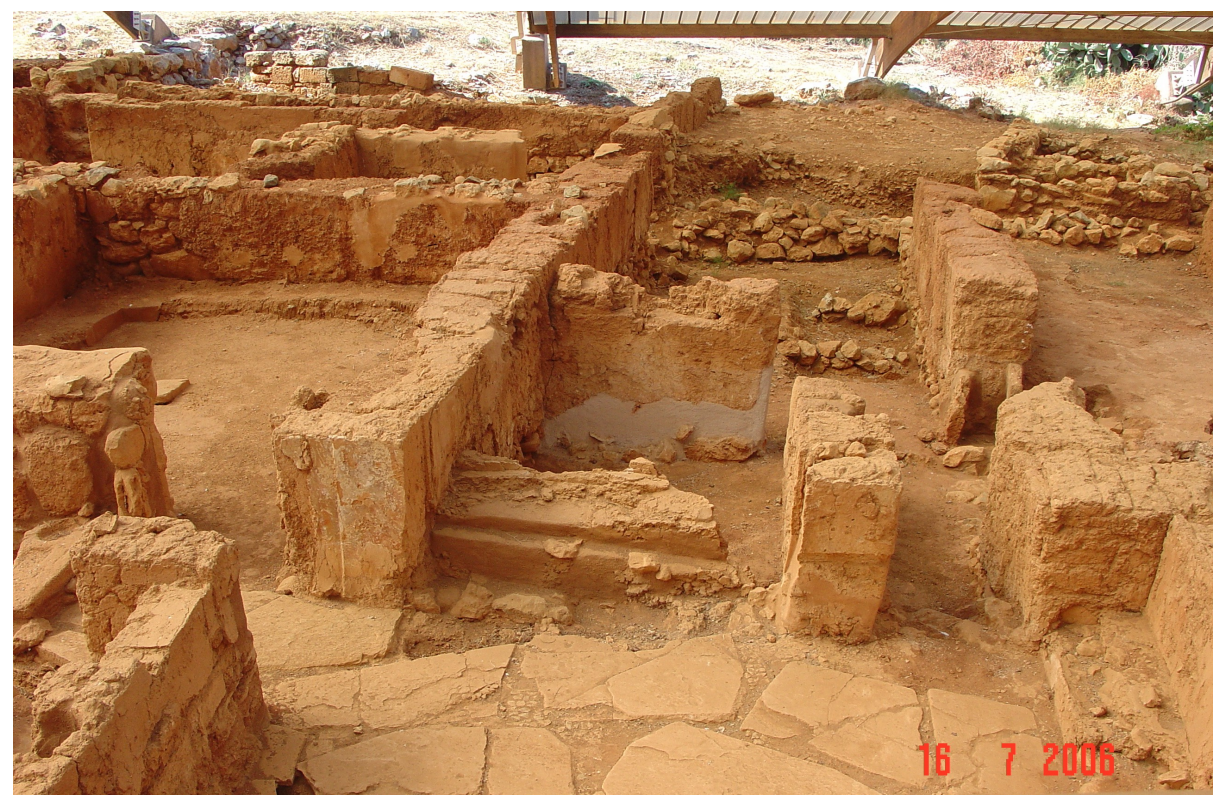

Fig. 54: Escadaria II B com degraus in loco, Casa Mu A.

Pela entrada principal em III 15 a leste se dá ao corredor III 1, que se abre para uma passagem III 10 que desemboca numa ampla sala III 16 com canaletas de escoamento, e se abre também, paralelamente se liga em uma outra passagem que possui um degrau reconstituído, III A, a passagem conecta as salas III 9, IIII 17, III8. Esse degrau reconstituido não aparenta fazer parte de uma escadaria. Ainda no corredor seguindo a leste, existe uma escadaria III B que se realmente fosse uma escadaria para o pavimento superior, seu poço estaria nas áreas III17 e III16. E continuando pelo corredor se dá a uma pequena passagem para as salas III 3 e III 4.

Para as áreas III 5, III 14 e III 18 (com função desconhecida) sua comunicação só seria possível através de uma escadaria, tipo I, que talvez se localizasse paralela à peça III14, em III C, que possui comprimento e apoio para uma escadaria conectando o pavimento superior ao inferior. O restante do edifício teria somente acessos pela via leste. A primeira, 
seguindo no eixo norte sul, desemboca para o conjunto de salas, I 20 - a, b e c. Esse conjunto apresenta um aspecto bem diferente, acredita-se que serviria para abrigo de animais (POURSAT, 1996, p. 43), assim como as peças III 3, III 11 a 13.

O acesso da peça III 11 possui também uma passagem externa própria com dois degraus ascendentes para a via leste. Paralelo ao muro exterior existe uma escadaria, onde encontram-se quatro degraus em ammouda, III D que conectariam ao pavimento superior. Há evidência do material encontrado durante a escavação nas salas I 20, III 3 e III 15 e III 13, que teria tombado do pavimento superior, consistindo em cerâmica e documentos contábeis (POURSAT, 1996, p. 45). Essa escadaria seria tipo L externa e seguiria a oeste acima da sala III 11.

E o último acesso pela via leste é através de uma pequena escadaria de desnível III E, que desemboca na peça III 13 e III 12.

Portanto, a Casa $\mathrm{Mu}$ A possui cinco escadarias para o pavimento superior, I A (U), II A (L), II B (I), III C (I) e III D (L). Contudo, essa última por ser uma escadaria externa não faz parte do catálogo. 


\section{Casa Mu B}

O edifício B possui uma planta regular com paredes perpendiculares, ocupa uma área de $540 \mathrm{~m}^{2}$, e foi dividido em dois setores, IV e V. Sua entrada principal situa-se pela pequena praça a oeste ao longo da calçada, IV 2, e talvez uma entrada secundária do lado oposto, ao norte do edifício pelo corredor IV 19.

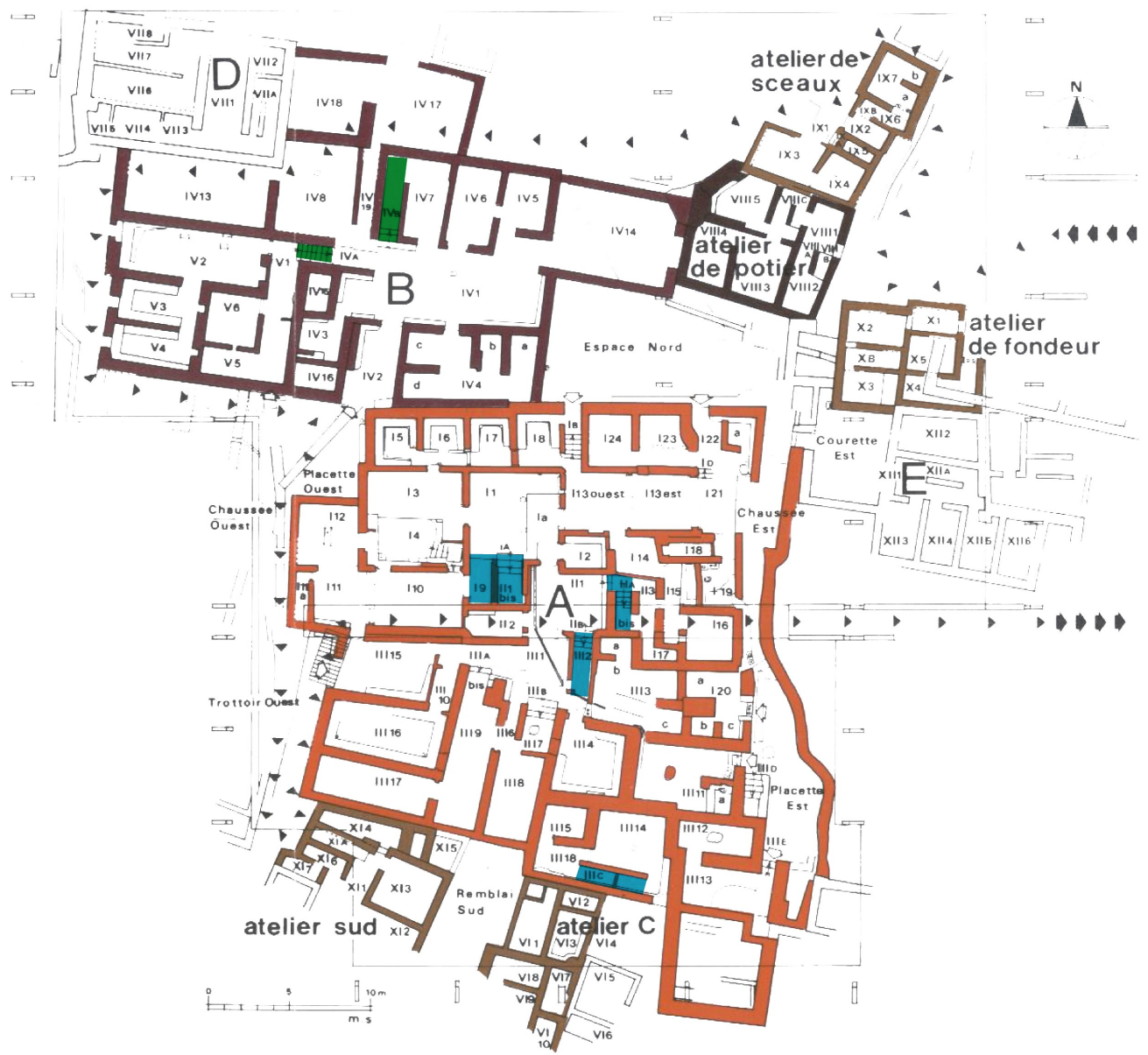

Fig. 55: Quadra Mu, casa Mu B e localização das escadarias (POURSAT, 1996).

$\mathrm{Na}$ entrada principal se depara ao vestíbulo IV 2 com bancos que ligam ao vestíbulo central estucado IV 1 que também possuem bancos nas paredes sul e sudoeste, dessa parte central do edifício se procede a diferentes conjunto de peças, inclusive a escadarias tanto 
para o subsolo como para o piso superior.

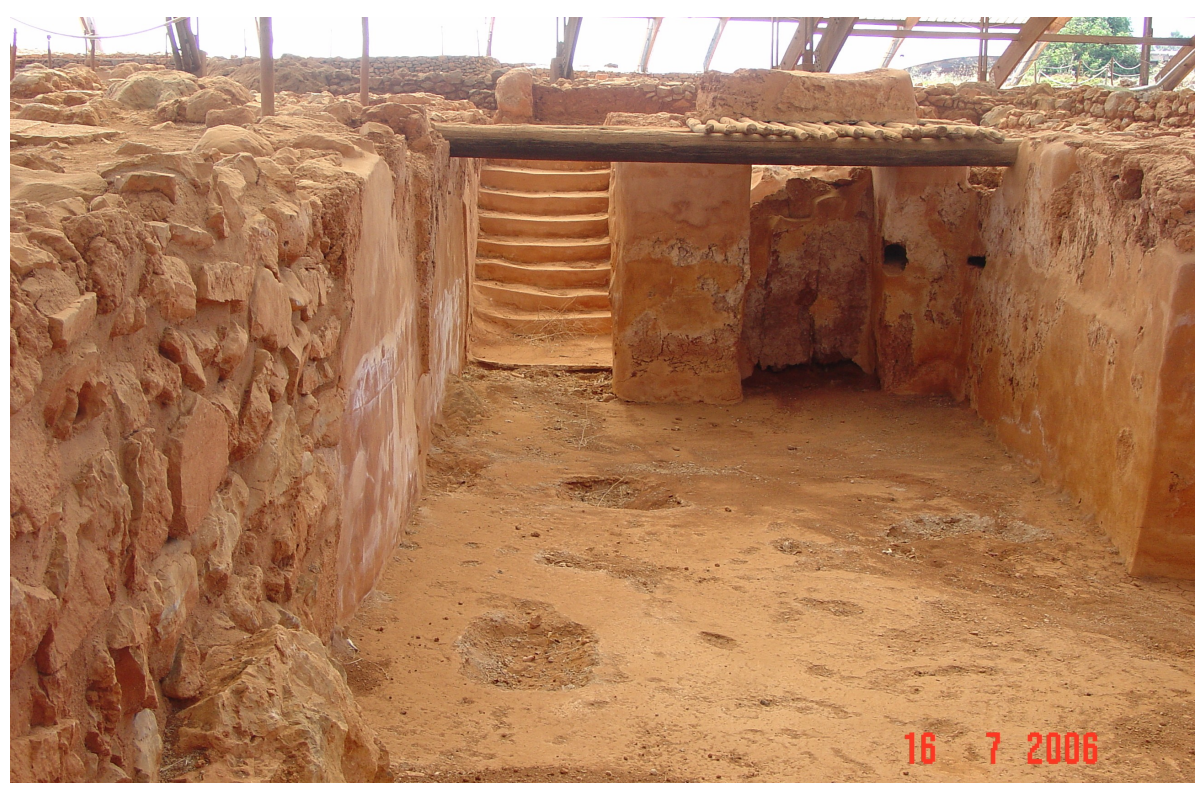

Fig. 56: Escadaria e degraus da IV A, casa Mu B.

Os vestígios são de duas escadarias. Uma é a IV A, situada a oeste do vestíbulo central IV 1. A escadaria é descendente tipo I e se comunica ao conjunto de salas a sudoeste do edifício, V1 - V6, e de excelente conservação. Ela possui no total de oito degraus, in loco, de aproximadamente $0,23 \mathrm{~m}$ de altura e 0,35 de largura para cada degrau, rompendo uma altura de 1,90 m. No conjunto foram evidênciados pontos de colocação de vigas de madeira no teto, visíveis nas paredes das peças V 5 e V 1. Nesse conjunto existem indícios de que abrigaria um santuário, tendo a peça V 6 uma sala de aparato. Contas de ágata e figuras de pedras foram achadas caídas no corredor V 5. 


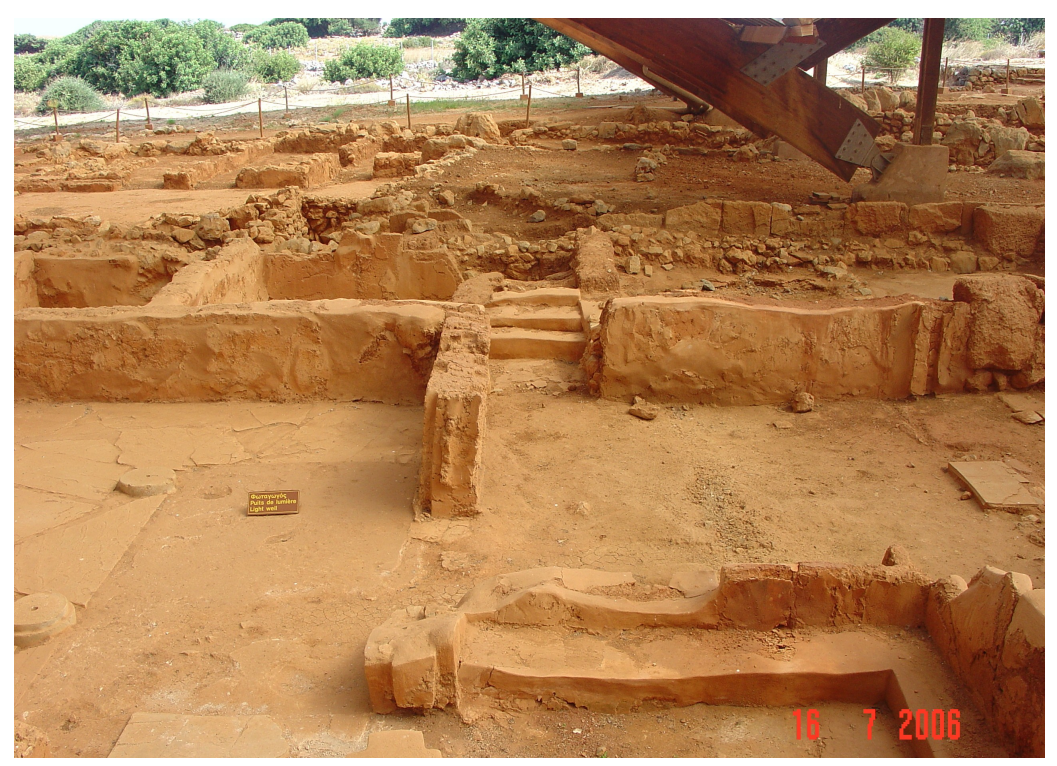

Fig. 57: Escadaria IV B, Casa Mu B.

A escadaria de acesso ao piso superior encontra-se a noroeste do vestíbulo central, IV B, e paralela à peça IV 7 e ao corredor IV 19. Os três degraus, in loco, não estão em boa conservação, mas além dessa fraca evidência, seu maior indício é sua localização e a forma da peça. A escadaria IV B seria tipo I, e não necessitaria de dois lances, principalmente porque possui um vão de 5,00 $\mathrm{m}$ de comprimento por 1,00 $\mathrm{m}$ de largura.

Foram encontrados nas peças IV 5 e IV 7 uma abundante quantidade de cerâmica comum e jarros com documentos hieroglíficos proveniente do piso superior, e acredita-se que haveria depósitos no andar superior (POURSAT, 1996, p.25).

O conjunto de peças da IV 4, que situa-se a sudeste do edifício, possui um mesmo aspecto do setor III do edifício A, mas não se sabe sua função (POURSAT, 1996, p. 24-31)

Todas peças restantes serviriam de depósitos, contudo nas áreas IV 8, IV 18 e IV 13 sua função é indeterminada também.

Acredita-se que o edifício B possuiria quatro pavimentos, o subsolo, térreo, 
pavimento superior e terraço. Contudo, se essa hipótese fosse mesmo verdade iriam encontrar muito mais vestígios dos pisos superiores.

As duas escadarias dessa construção se configuram como sendo de conexão e de fachada. 


\subsection{Edifícios Públicos}

\section{Cripta Hipostila}

A Cripta Hipostila situa-se a oeste do palácio, pela via em direção à quadra Delta e à praia. Do palácio o edifício encontra-se antes da quadra Delta a sul, ao norte faz divisa por entre a quadra Kapa e a ágora, e a leste um conjunto de armazéns ou depósitos, pertencentes à ágora, chamados de depósitos meridionais (ALLEGRETTE, 1997, p.101). Foi descoberta em 1957, sendo a estrutura escavada apenas entre 1960-1963 e 1965-1966 por Van Effenterre, com a participação em 1960-1962 de Marie-Claire Amouretti, que fizeram estudos da estrutura em 1965 e 1968, visando a publicação do edifício. Estudos mais aprofundados foram realizados também em 1995 e 1996, direção de Allegrette e Schmid.

A cronologia da sua construção é do período entre o fim do Minóico Médio IB e o Minóico Médio III. Houve abandono da estrutura durante o fim do Minóico Médio II. E transformação, reutilização e ruína definitiva do edifício, no Minóico Médio IIIB - Minóico Recente IA (ALLEGRETE, 1997, p. 198).

O edifício se composto de dois grandes blocos. O corpo principal formado por uma série de cinco salas subterrâneas alinhadas no sentido leste-oeste, salas C1 a C5, e a sudoeste uma série de cinco armazénsalinhados leste-oeste dotados de canaletas e vasos coletores, que se conectam através de uma escadaria de desnível com três degraus pela sala C5 e o depósito M2. Os depósitos estão 1,00 m acima do piso do corpo principal, enquanto este se encontra a 2,10 m abaixo do nível atual. A entrada principal do edifício situa-se a sudoeste do corpo principal e se faz por uma escadaria, 1, descendente dois lances com um patamar intermediário, tipo $\mathbf{L}$, que desemboca na sala 1 . O primeiro lance se compõe de seis 
degraus que atingem o patamar intermediário e segue para o segundo lance leste-oeste que se compõe de dois degraus que desembocam sobre o banco da sala 1, apresentando sinais de batentes na entrada superior e no degrau do segundo lance. Todos os degraus são feitos em ammouda, compondo-se de uma ou duas lajes dispostas sobre a terra, recobertos de estuque, técnica comum na arquitetura minóica. Os degraus têm alturas entre 0,10/0,18 m, largura de 1,50 m e profundidade entre 0,40/0,47 m (ALLEGRETTE, 1997, p. 90).

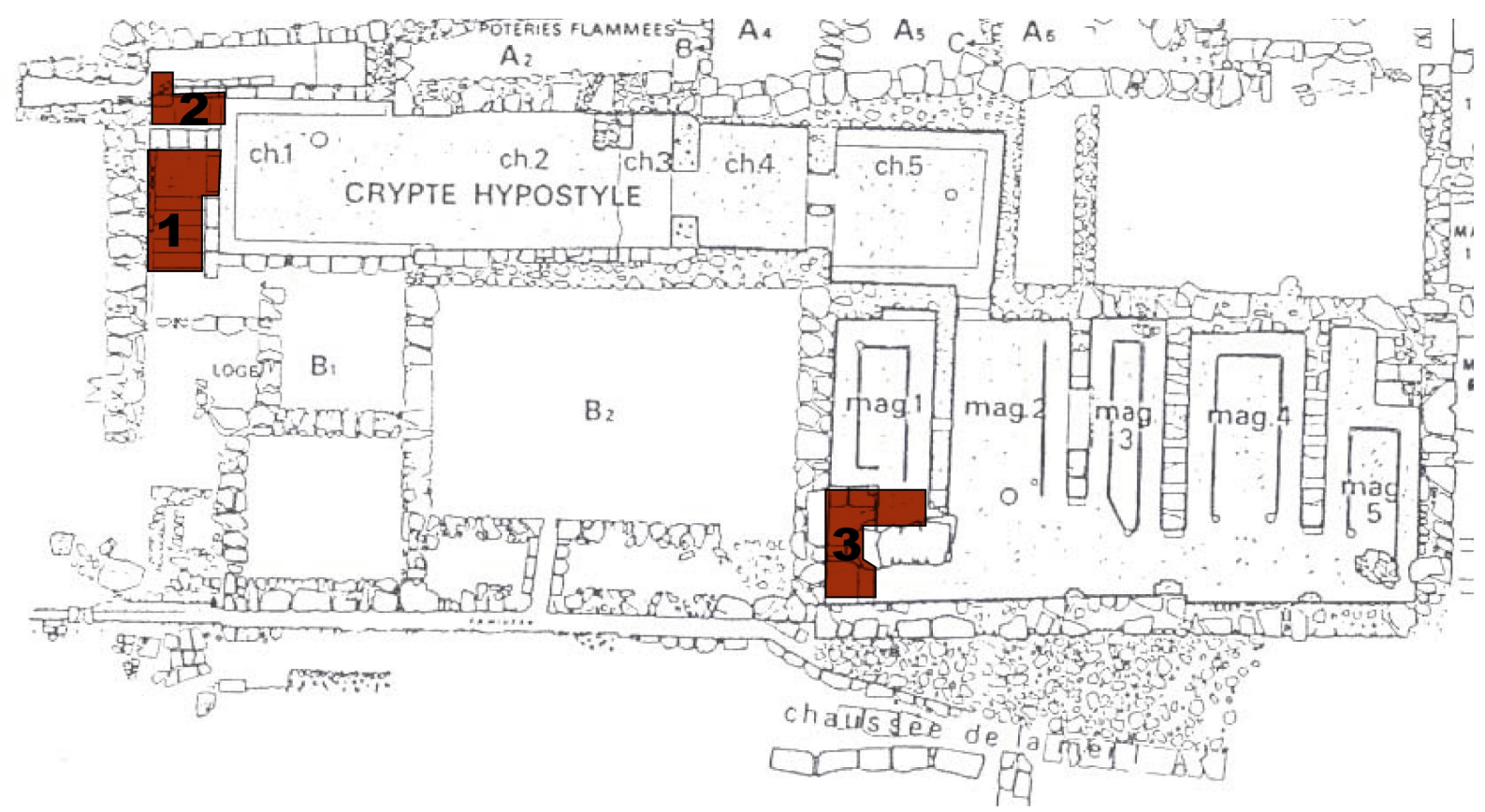

Fig. 58: Planta da Cripta Hipostila e localização das escadarias (EFFENTERRE, 1980, fig. 265).

Paralela ao patamar intermediário da escadaria de entrada e do mesmo lado da sala 1, a oeste, há a parede divisória, feita com ortostatos de ammouda, e uma outra outra escadaria, 2. Acredita-se que essa escadaria conectava-se ao piso superior. A escadaria de quatro degraus acima do banco e um patamar estucado voltado para a borda de um bloco cuidadosamente arredondado em quarto de círculo. A escadaria tipo $\mathbf{U}$ se estenderia pela peça a norte que poderia ser uma valeta para escoar a água da chuva. Os degraus medem de $0,23 \mathrm{~m}$ a 0,27 de altura, com profundidade de $0,32 \mathrm{~m}$ a 0,36 por 0,85 de largura (AMOURETTI, 
1957-62, p. 16). Essa escadaria teria uma inclinação maior do que a da entrada principal, sendo ela mais restrita.

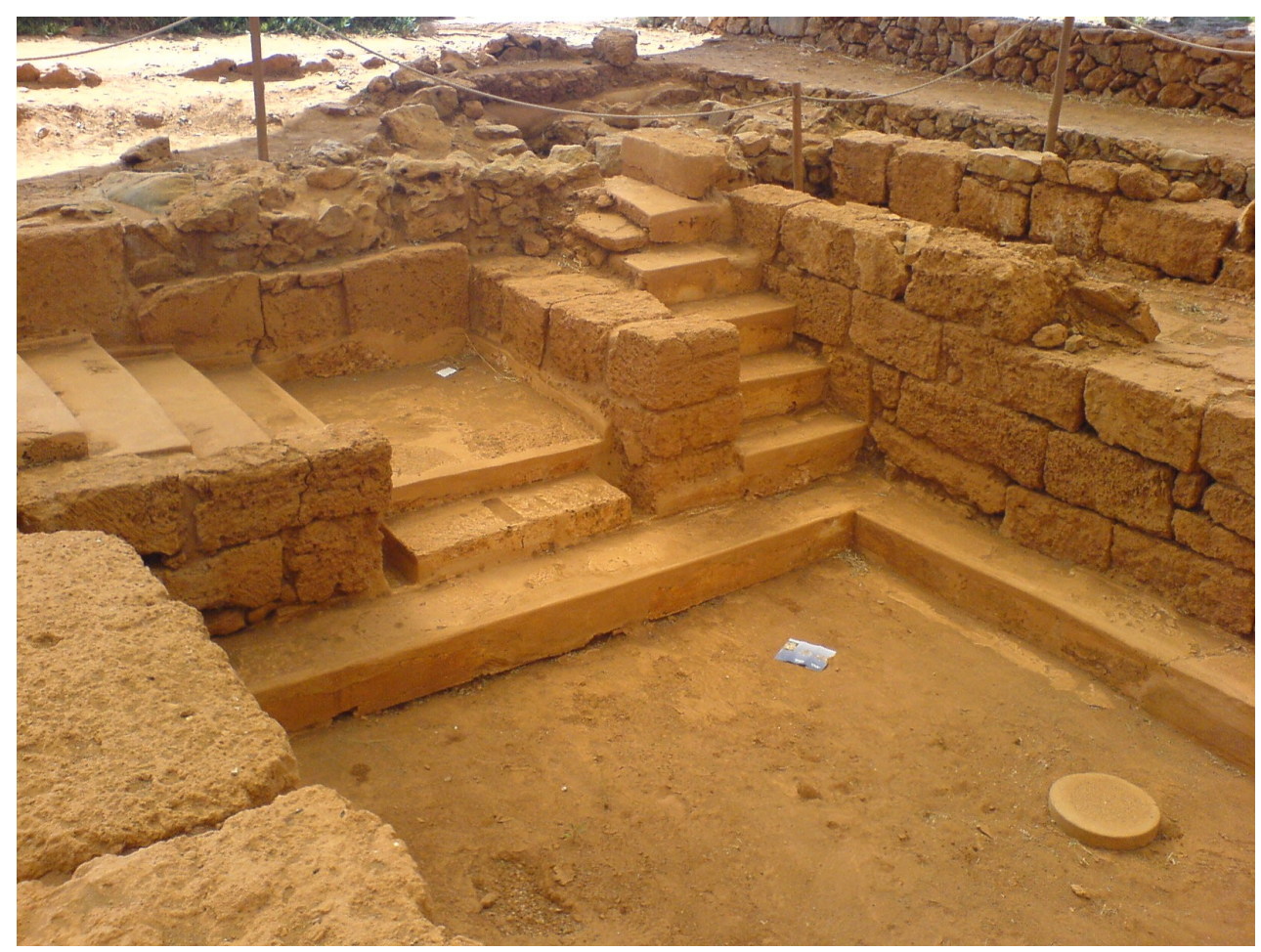

Fig. 59: À esquerda escadaria 1, entrada, e à direita escadaria 2, Cripta Hipostila.

No bloco com os cinco depósitos há presença de uma outra escadaria, 3, a sudoeste paralelo ao depósito 1, tipo L. A escada com largura de 1,20 m, cujo primeiro degrau, feito de uma ammouda estucada, tem 0,24 m de altura e 0,42 $\mathrm{m}$ de profundidade; o segundo degrau tem $0,14 \mathrm{~m}$ de altura e $0,42 \mathrm{~m}$ de profundidade e é feito de dois blocos de ammouda trabalhados se prolongando por um boleado no bloco estucado no centro. Talvez fosse uma pedra reutilizada e se poderia recuperar um $3^{\circ}$ degrau formando patamar, ou talvez fosse um dispositivo que reduzisse a largura da escada nesse nível (AMOURETTI, 1976, p.29). Em 1999 foi descoberto no piso diante desta escadaria um orifício estucado lateral destinado ao pivô de uma porta, o que sugere o bloqueio desse acesso para outro piso. ${ }^{16} \mathrm{De}$

16 Informação pessoal com Allegrette. 
qualquer jeito, existia uma ligação entre essa escada e o maciço de terra e ammouda ao Norte com altura de 0,67 m. Ainda que houvesse uma sideropetra que atrapalhasse, encontrou-se entre as duas partes uma ammouda trabalhada que parecia destinada a um batente cujo encaixe estaria cavado a Leste (largura: $0,25 \mathrm{~m}$ e profundidade: $0,10 \mathrm{~m}$ ). Este reduto seria a base de outra escadaria levando ao pavimento superior ou ao teto (ALLEGRETTE, 1997, p.102). Essa escadaria também seria de maior inclinação, contudo ela possui uma largura maior do que a da sala 1 , talvez por causa do uso de transporte de vasos para o pavimento superior.

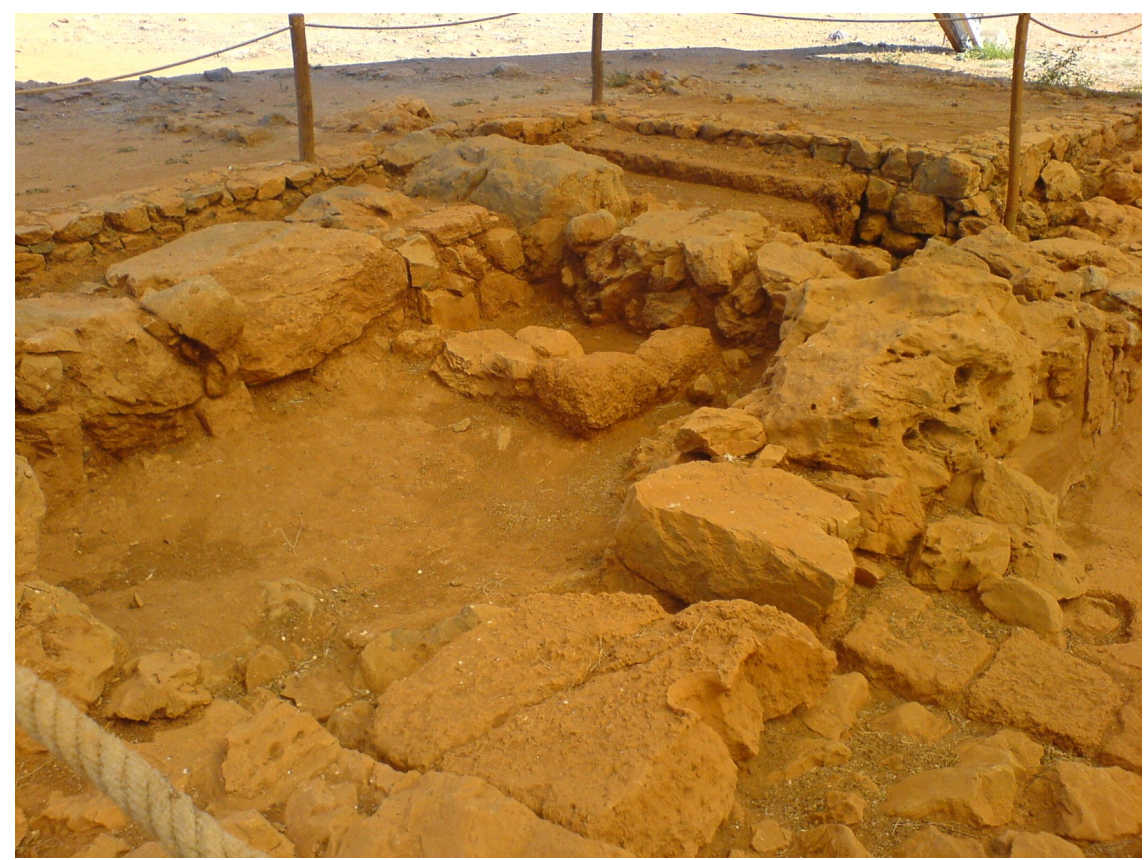

Fig. 60: Poço da escadaria 3, Cripta Hipostila.

Pela resconstituição do edifício (AMOURETTI, 1957-62) a escadaria, 2, da sala 1 conectaria somente ao pavimento superior acima do corpo principal, enquanto a escadaria, 3, do bloco dos armazéns seria atribuído da mesma maneira, acima desse bloco, não possuindo conexão pelo pavimento superior.

A escadaria de entrada, 1, se configura como sendo de conexão e estética; 
escadaria, 2, que conecta o piso superior do corpo principal seria de conexão e fachada; e a escadaria, 3, do bloco de armazéns seria de função, conexão e fachada.

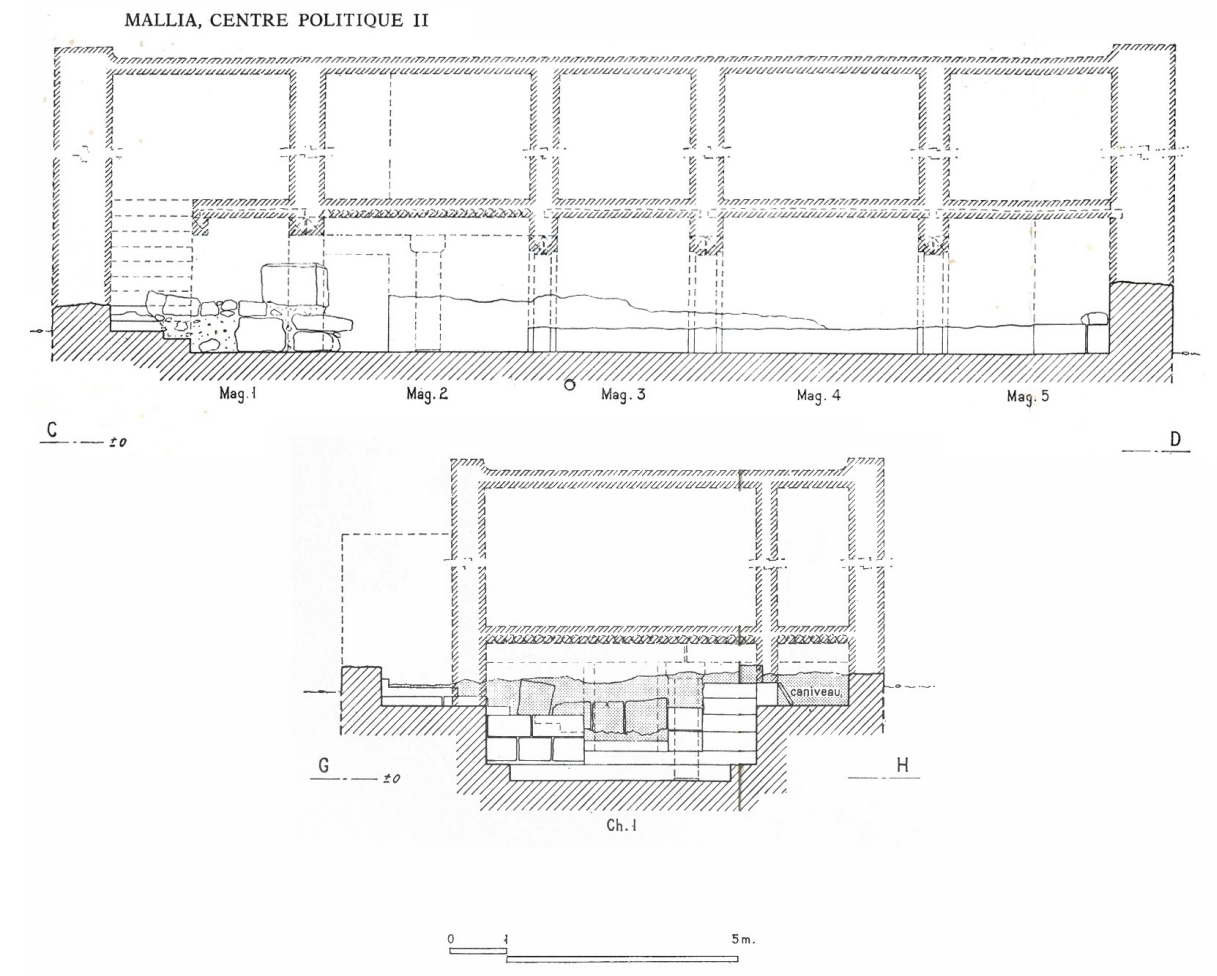

Fig. 61: Reconstituição segundo Amouretti, cortes da Cripta Hipostila (AMOURETTI, 1957-62). 


\section{PALÁCIO}

Para facilitar a leitura das quadras optamos por usar um recurso simples de cores na planta do palácio, mostrando a localização das escadas e suas respectivas quadras.

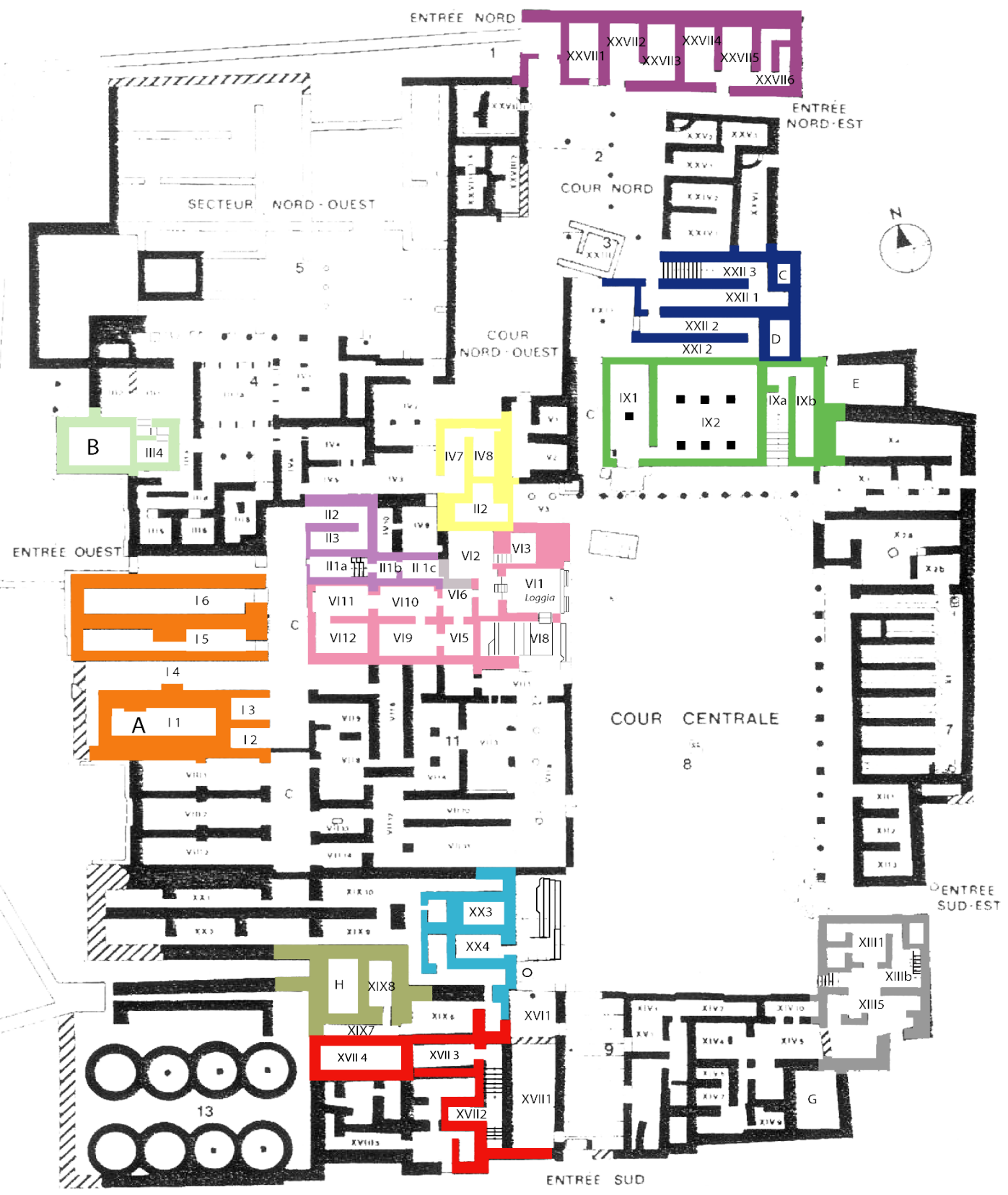

Fig. 62: Planta do palácio de Mália e localização das quadras e áreas das escadarias. 


\section{Quadras I, áreas I 2 e I 3}

A quadra se localiza na ala oeste do palácio. Por entre a quadra III e a peça I 6 está a entrada oeste que abre-se para o corredor perpendicular $\mathrm{C}$ a leste, que nos leva à quadra em questão.. A função das peças I 4, I 5 e I 6 seria a de suportes para o pavimento superior e/ou para estocagem. Mesmo não houvesse vestígios de seu conteúdo, existem similaridade com os depósitos ocidentais dos palácios de Cnossos e Festos que reforçam esta hipótese (ALLEGRETTE, 1991, p.33). Na peça A (I 1) está o primeiro de cinco bastiões do palácio, e a leste estão as peças I 2 e I 3, que foram consideradas inicialmente um poço de uma escadaria de tipo U, para o piso superior (CHAPOUTHIER e CHARBONNEAUX, 1922-24, p.7). Essa opinião não é compartilhada por Pelon (citado por ALLEGRETTE, 1991, p.32).

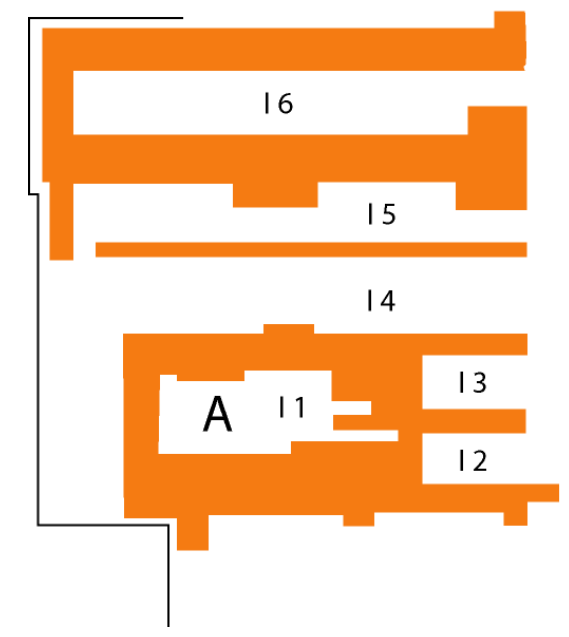

Fig. 63: Quadra I, bastião A, I 2 e I 3, suposto poço de escada, I 4 e I 6 , contrafortes.

Suas dimensões são similares, apresentando 3,65 - 3,70 $\mathrm{m}$ de comprimento e 2,10 $\mathrm{m}$ de largura para cada uma das peças, que estão separadas por uma parede de $0,70 / 0,80 \mathrm{~m}$ de espessura. A parede oeste se compõe de tijolos apoiados contra o muro I 1 (que possui uma 
espessura de 3,00/4,00 m), sendo que a partir de $0,34 \mathrm{~m}$ de altura a coloração passa de castanho para avermelhado, indício de queima que sugere a existência de um piso desaparecido (Pelon, 1980, p.232).

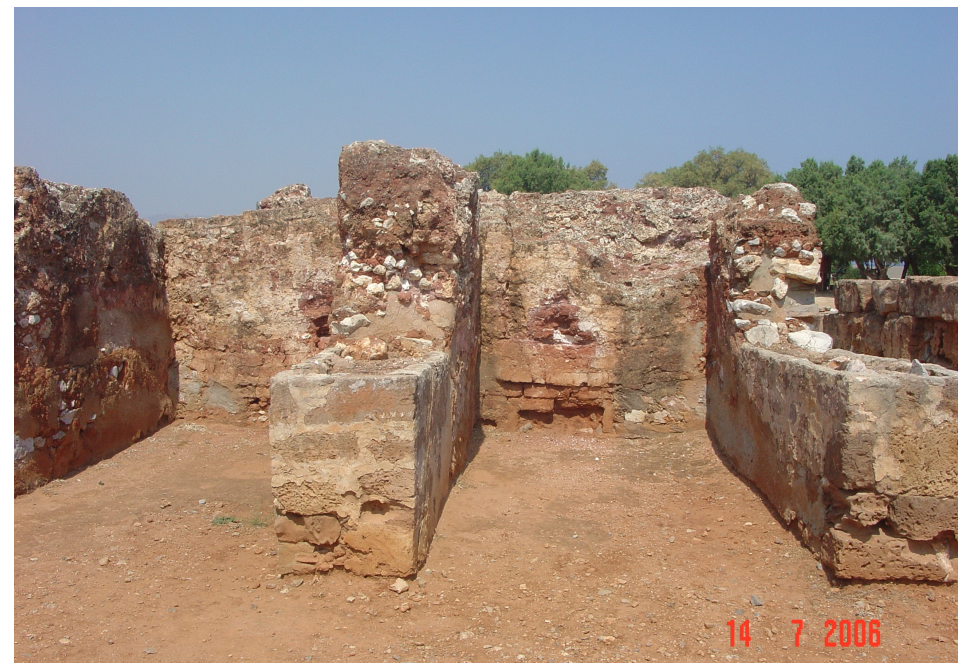

Fig. 64: Quadra I, palácio de Mália. Área I 2, à esquerda e área I

Apesar de não possuir vestígios de degraus, as peças I 2 e I 3 poderiam suportar uma escadaria para o nível superior. Um outra opinião é a do arquiteto Schmid, que sugere uma escadaria do lado extremo oeste que serviria de entrada externa do palácio, a qual levaria diretamente para o nível superior e o bastião A serviria de suporte para essa escadaria (Maquete, 1996). Pelo trabalho de Schmid infelizmente não sabemos a função atribuída para as salas I 2 e 3. É difícil dizer que realmente a função dessas peças fosse vinculada apenas a uma escadaria, que possuiria dimensões monumentais; entretanto, as peças fornecem suporte para tal sustentação. Sendo assim, para Schmid considera uma escadaria de tipo I, e não a de tipo $\mathbf{U}$, como foi sugerido pelos primeiros pesquisadores. Seu acesso não estaria restrito e permitiria também um grande número de pessoas em sua circulação devido a suas dimensões. Contudo, não existe nenhuma evidência em outros sítios minóicos desse tipo de entrada e nem 
indícios na fachada oeste de uma escadaria. Que nos leva a acreditar que a função das salas I 2 e I 3 fossem de apoio a uma escadaria tipo U e seu acesso seria interno pelo corredor C.

A escadaria se encaixa nos elementos configuradores: de fachada e de conexão. 


\section{Quadra II, áreas II2 e II3}

No final do corredor C a norte se localiza a quadra II. Primeiramente, se encontra um conjunto de três salas interligadas, II 1 a, II 1 b e II 1 c, com profundidade variada e chamadas pelos primeiros pesquisadores de armazéns alpha, beta e gama. Foi identificada uma escada de desnível que possui três degraus entre alpha e beta, onde foram encontrados vários vasos de cerâmica e pitois (CHAPOUTHIER e CHARBONNEAUX, 1922-24, p.10). Provável um deposito de bens de culto ou ritual. (ALLEGRETTE, P.35).

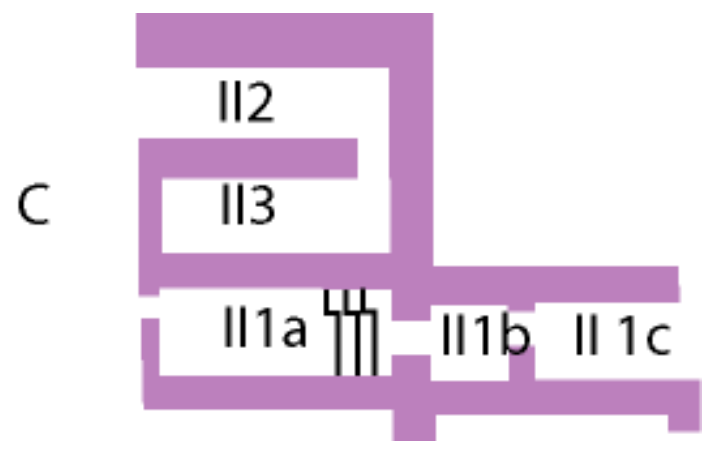

Fig. 65: Quadra II

As outras duas peças dessa quadra se encontram na extremidade norte do corredor C, II 2 e II 3, paralelas ao conjunto II 1 a-c.

Para Pelon, essas duas peças formariam um vão de escadaria de ligação entre os depósitos da ala oeste e o pavimento superior (PELON, p.180, citado por ALLEGRETTE, 1991, p. 35). Diferente das peças I 2 e I 3, as peças da quadra II possui um plano próprio de uma escadaria tipo $\mathbf{U}$, similaras às quadras IV, IX, XXII e XXVII, assim como também comumente se encontra nas residências desse período. 


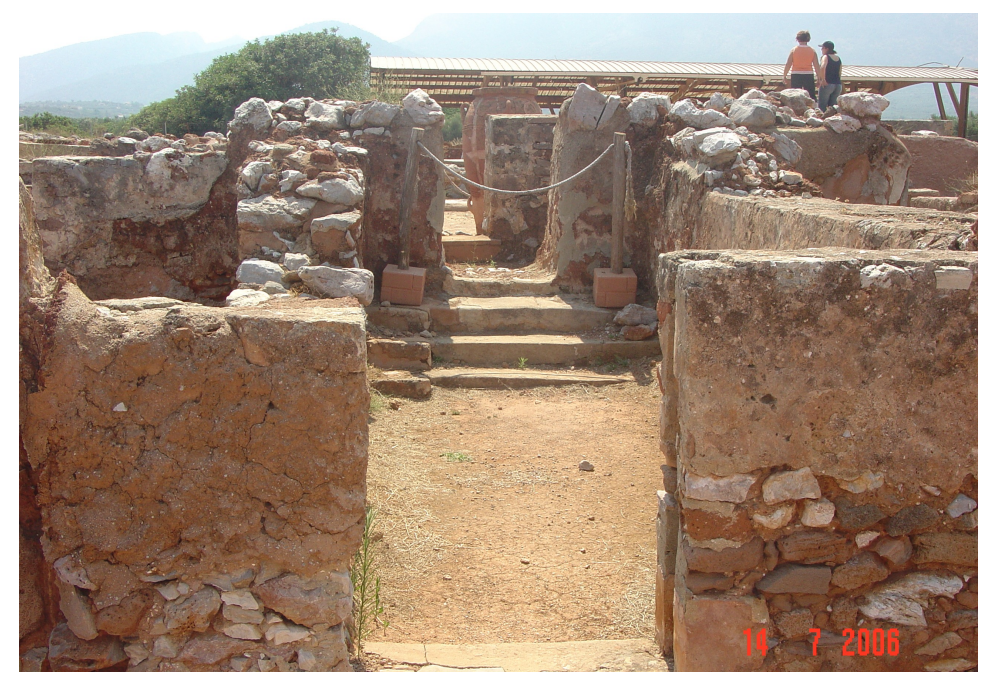

Fig. 66: Quadra II, palácio de Mália. Peças II 1 a, b e c.

As duas áreas são similares: II 2 possui 4,50 m de comprimento e 1,50 de largura, enquanto a II 3 possui uma largura de 1,80 e 5,00 de comprimento. Não existe vestígios de degraus, talvez porque possuisse uma escadaria leve de madeira. Nossos cálculos indicam que seus degraus teriam por volta de $0,30 \mathrm{~m}$ de patamar e $0,17 \mathrm{~m}$ de espelho, num total de 18 degraus mais um patamar intermediário. Essa escadaria é restrita, não só pelo fato dela se situar em um lugar distante de circulação pública no palácio, mas porque talvez possuísse uma porta de acesso no corredor C.

Se configura como sendo uma escadaria de conexão. 


\section{Quadra IV, espaços IV7 e IV8}

A quadra IV situa-se na porção noroeste do palácio, possui no total doze peças em um traçado complexo, seu único acesso é pelo setor noroeste através da peça IV 2.

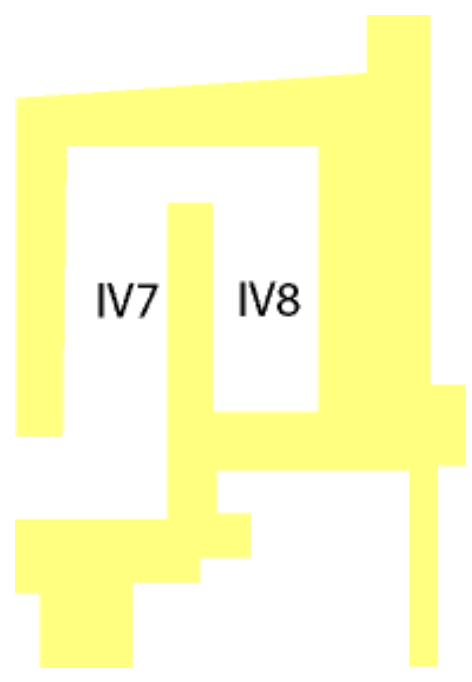

Fig. 67: Quadra IV, peças IV 7 e IV 8 .

As peças IV 7 e IV 8 possuem uma disposição que sugere que abrangeriam uma escadaria de dois lances com patamar intermediário, tipo U (PELON, 1980, p. 105; EFFENTERRE, 1980, p. 309). Estas peças, IV 7 e IV8 possuem dimensões, respectivamente, de $1,75 / 1,80$ x 4,50 m e 1,75/1,80 x 5,00 m. Estão separados por uma parede estreita de 0,80 m, sendo que a extremidade norte de IV7 é o acesso para a IV8, lateral à quadra V. Nesta parede entre as duas quadras, a espessura total atinge $1,80 \mathrm{~m}$. Na parede sul de IV 8 há ainda uma canaleta de ammouda junto ao piso, talvez relacionada ao orifício na parede sul de IV 7 , cerca de $0,20 \mathrm{~m}$ acima do piso. Notam-se ainda sinais de um revestimento de terra em ambas as peças. Seu acesso é pelo espaço IV 3, e possuía uma porta na sua entrada, pois existe evidência de uma soleira (CHAPOUTHIER e CHARBONNEAUX, 1922-1924, p.17). Na sala 
IV 8 foram encontrados vários objetos de terracota, chamados de medalhões, barras, tabletes talhadas de inscrições hieroglíficas ou lineares, impressões de selos, fragmentos de pequenos vasos.

A estrutura das paredes em volta desses espaço seria suficiente para suportar uma escadaria que conectaria a um pavimento superior. Pelon ainda chama a atenção para um pilar de ammouda no extremo norte da parede divisória entra as duas peças, característico deste tipo de construção, que funciona como suporte para o patamar intermediário dessa escadaria (PELON, 1980, p. 105). Apesar de Van Effenterre sugerir uma inclinação semelhante à Grande Escadaria a altura do pavimento térreo seria praticamente igual. Contudo, como ele mesmo nos mostra, essa escadaria teria um número menor de degraus que tenderia a uma altura maior dos espelhos ${ }^{17}$, o que acarretaria mais esforço físico para sua comunicação. Dessa maneira, a escadaria é restrita, cujo acesso teria uma porta. Se admitirmos as hipóteses dos pesquisadores Graham $(1979,49)$ e Michailidou $(1990,293)$, essa escadaria conectaria a um pavimento importante, talvez aos aposentos dos monarcas ou às salas de administração do palácio. Entretanto, o que chama a atenção são os achados na sala IV 8. Com uma escadaria ocupando espaço na sala IV 7, como poderia ter acesso ao espaço aberto que ela mesma faria? Observando a planta de Van Effenterre, isso seria possível, enquanto na planta do sítio existe uma parede, impossibilitando seu acesso. Seria necessário ter maiores dados sobre contexto de achado desse material.

17 Parte vertical no fundo do degrau. 


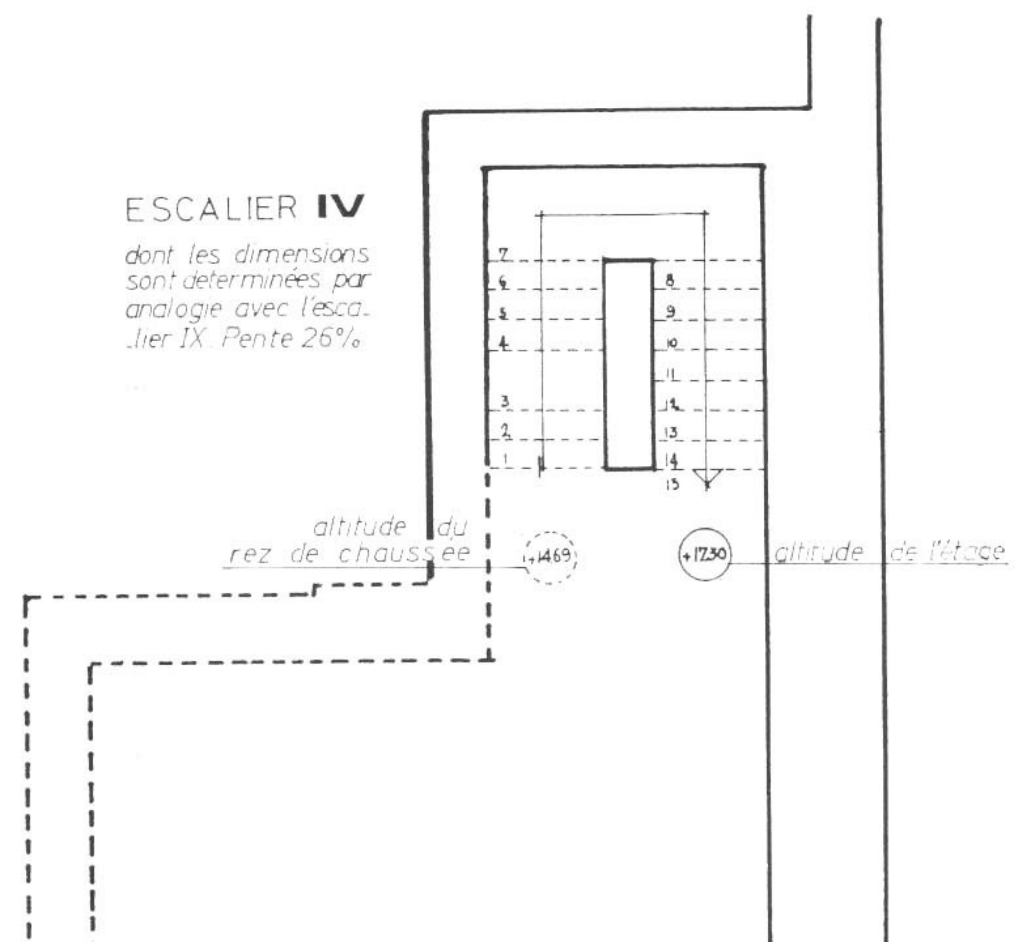

Fig. 68: Planta reconstituição segundo Ven Effenterre (1980, fig.423).

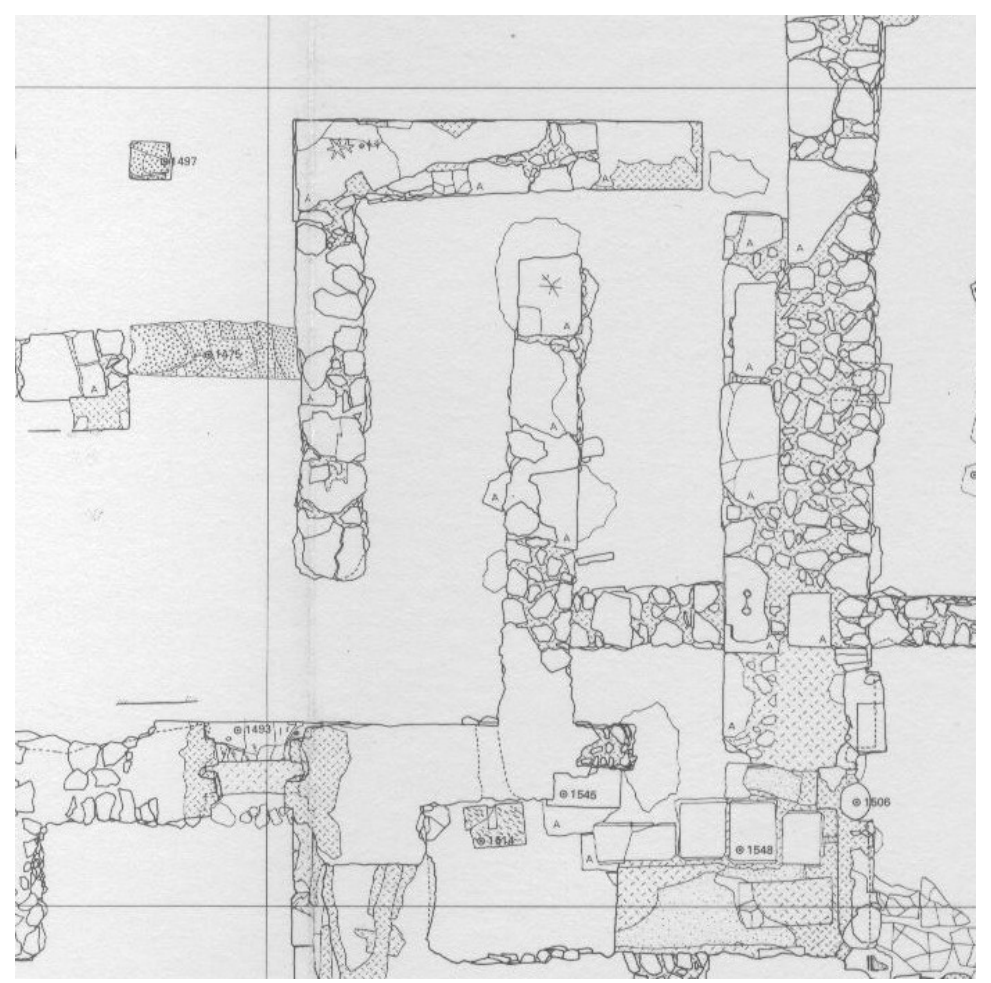

Fig. 69: Planta das peças IV 7 e IV 8 (MALLIA, 1974). 


\section{Quadra VI, área VI 8, a Grande Escadaria:}

A quadra IV se localiza no setor oeste do palácio, tendo como limite a quadra IV ao norte, a quadra II a oeste, o pátio central a leste e a quadra VII ao sul. Ela compõe de quatorze peças que podem ser agrupadas em conjuntos distintos e de acessos externos múltiplos (ALLEGRETE, 1991, p. 41).

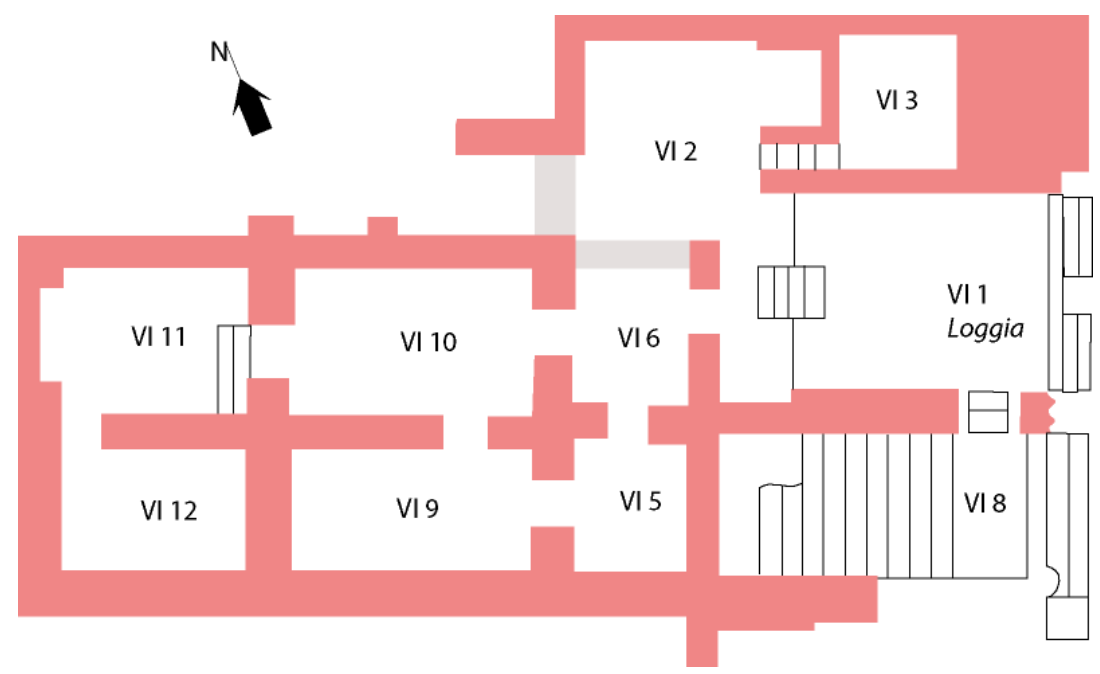

Fig. 70: Quadra VI.

A Grande Escadaria está localizada defronte ao pátio central, tendo a base voltada para esta área. Seu alinhamento é perpendicular ao eixo maior do pátio. Ela possui uma largura de 3,22 m, com nove degraus conservados de aspropetra, dos quais cinco foram encontrados in loco e quatro foram recolocados. A base da escadaria é delimitada por dois pilares quadrados com aproximadamente $1,00 \mathrm{~m}$ de cada lado. $\mathrm{Na}$ base da escadaria há uma soleira e em suas extremidades há orifícios para encaixe de pivôs de portas, separados por três metros, assim sugerindo portas duplas. Essa soleira está diante de um patamar com 3,45 m de largura e 1,58 m de profundidade, formada por três alinhamentos de lajes, que se conectam à base da escadaria. Seus degraus medem 0,10 a $0,15 \mathrm{~m}$ de altura e 0,42 a $0,46 \mathrm{~m}$ de 
profundidade, com exceção do último, que chega a 0,60 m. Cada degrau se compõe de três placas separadas por intervalos estucados de $0,10 \mathrm{~m}$. A altura total da escadaria conservada é de 1,27 m. A profundidade do último degrau sugere a existência de um patamar que, devido a pouca espessura das paredes oeste, poderia ser uma estrutura de madeira. Essa escadaria define o limite da quadra VII ao sul (PELON p. 138-140). Existe um espaço sob essa escadaria do lado oeste, dentro do qual foram encontrados taças e fragmentos de um vaso decorado sobre uma bancada estucada. Para Pelon, esse espaço estaria preenchido para sustentação da escadaria e esse material seria parte de um solo antigo (PELON p. 138-140). De acordo com Van Effenterre, esta escadaria teria uma inclinação de $27 \%$, o que poderia sugerir um prolongamento até a altura de $17,30 \mathrm{~m}^{18}$, portanto, uma altura de 2,45 $\mathrm{m}$ em relação ao nível do pátio central. Para esse autor mais sete degraus podem ser reconstituídos, os quais atingiriam o pavimento superior, chegando a um total de vinte e um degraus, incluindo a soleira e o patamar da escadaria (EFFENTERRE, 1980, p.310).

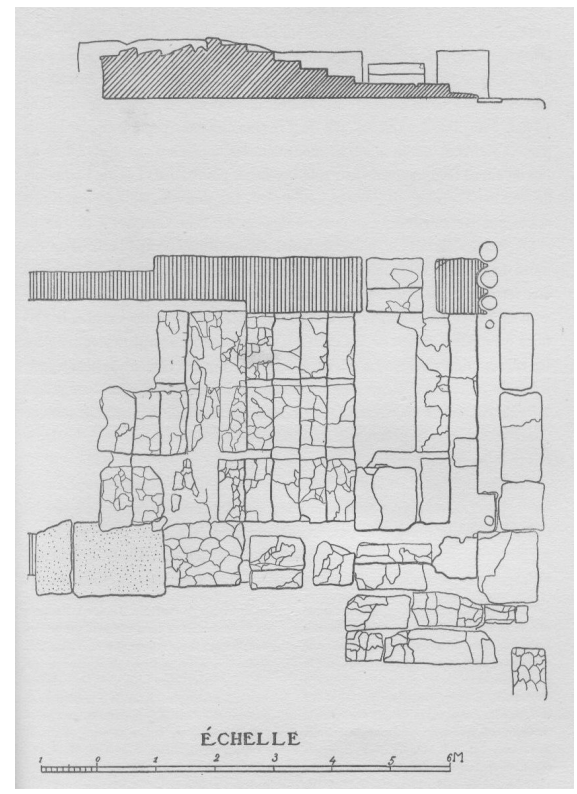

Fig. 71: Planta e corte da escadaria (CHAPOUTHIER e CHARBONNEAUX,

18- Para Van Effenterre, o pavimento superior do palácio de Mália estaria por volta de 17,30 m em relação ao nível do mar. O nivel do patio central é de 14,85. Portanto uma altura de 2,45 m. EFFENTERRE, 1980, p. 305ss. 


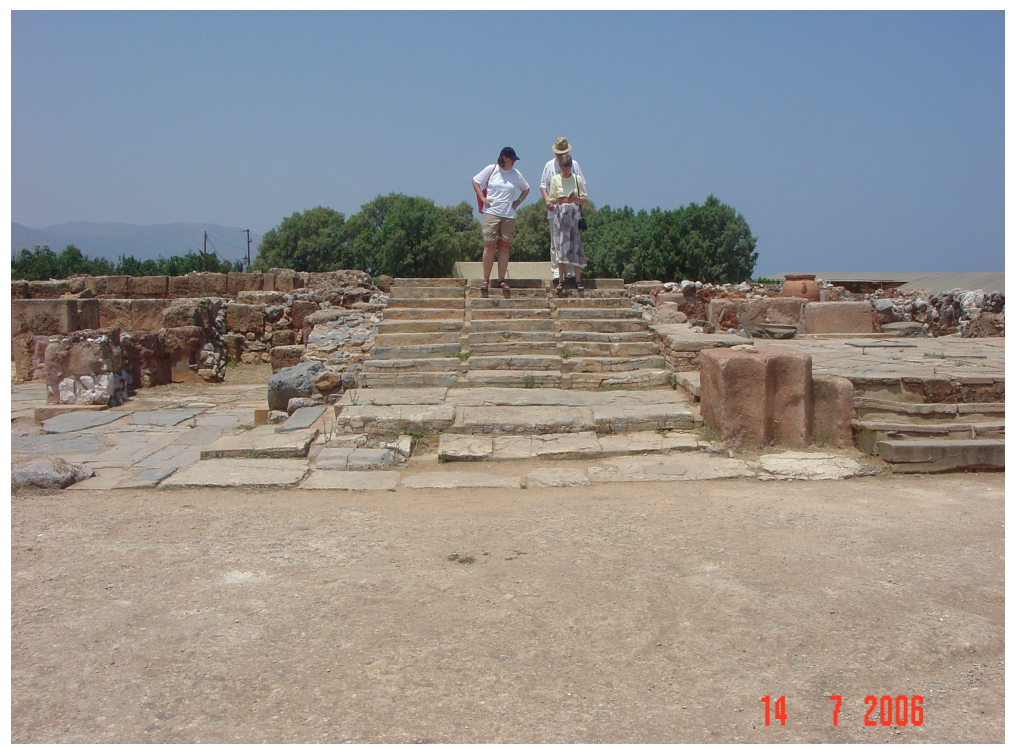

Fig. 72: Grande Escadaria, vista do pátio central.

De acordo com o texto dos arqueólogos responsáveis pela escavação inicial existe diferença nas medidas, como sua largura, de 3,20 m, em três zonas equivalentes. Sua altura total é de 1,40m. (Chapouthier \& Charbonneaux, 1922-1924, p.17).

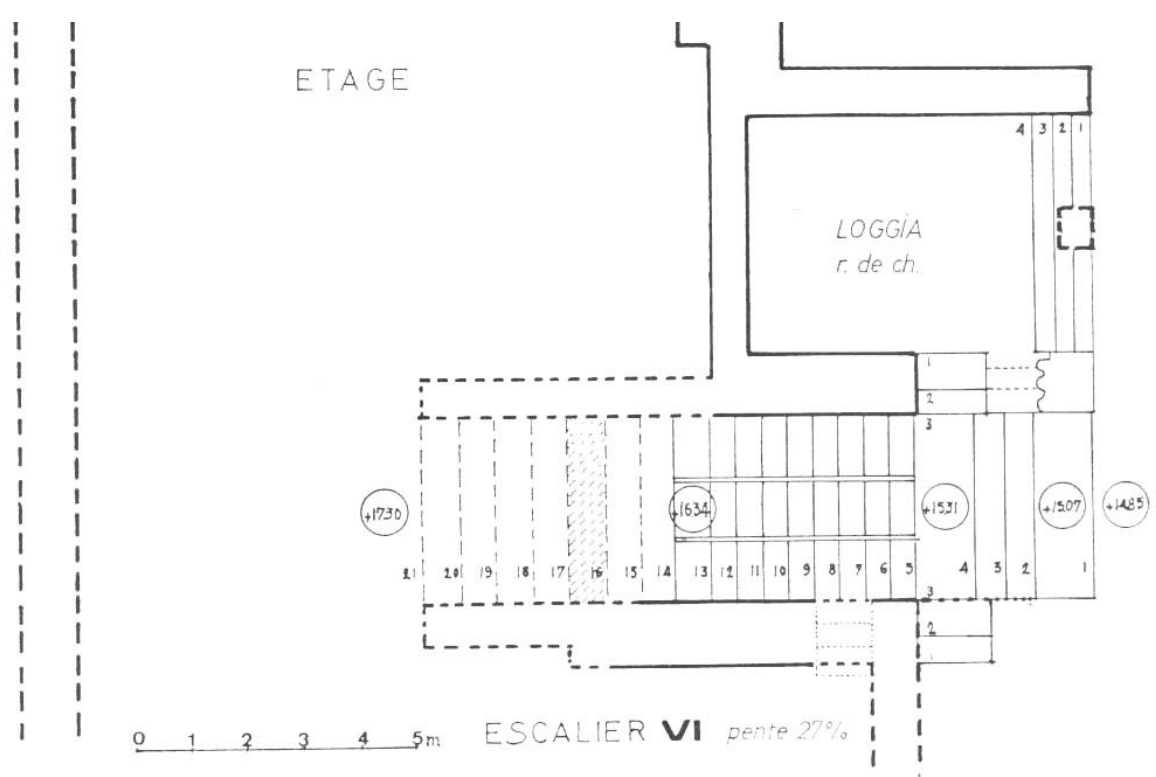

Fig. 73: Recosntituição da escadaria VI, segundo Ven Effenterre. Linhas contínuas, degraus existentes; pontilhadas reconstituição (EFFENTERRE, 1980, p.310).

A proposta de reconstituição do segundo pavimento feita por Graham, que teria a sala de Recepção naquele piso, está ligada a esta escadaria, mas ele menciona somente a 
planta do interior e divisórias, e não os degraus.

Apesar do acesso à Grande Escadaria ser visível pelo pátio central e possuir uma inclinação de ângulo baixo (o que indicaria uma escadaria pública), seu uso é restrito, pelo fato de possuir na soleira diante do pátio central indícios que apontam para portas duplas. Se apoiarmos a sugestão de Graham, de que conectaria a sala de Recepção, o segundo pavimento serviria para uma sala especial. E neste mesmo pavimento existiria um terraço de acesso que daria vista para o pátio central. Esta vista é, sem dúvida, o melhor ângulo para assistir cerimônias, tanto esportivas como religiosas, assim como o controle visual do seu público. Talvez a escadaria fosse usada somente por algumas pessoas ou em algumas ocasiões. Sem dúvida alguma é uma escadaria especial.

A escadaria se encaixa nos três elementos configuradores: fachada (tanto externa, como interna), estética e de conexão. 


\section{Escadaria Monumental}

Localizada nos limites das quadras XIX e XVI, VII e o pátio central, essa escadaria foi descrita inicialmente por Chapouthier e Joly (1925-26, p.14-18.). Seu acesso é pelo sudoeste do pátio central, próximo a entrada sul do palácio.

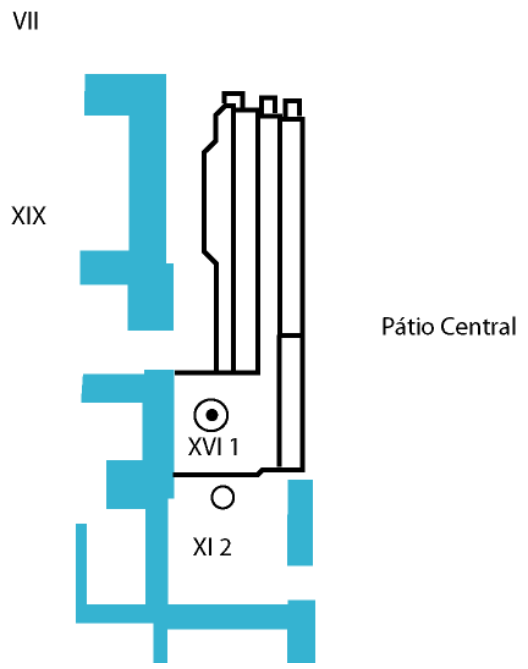

Fig. 74: Quadra XVI.

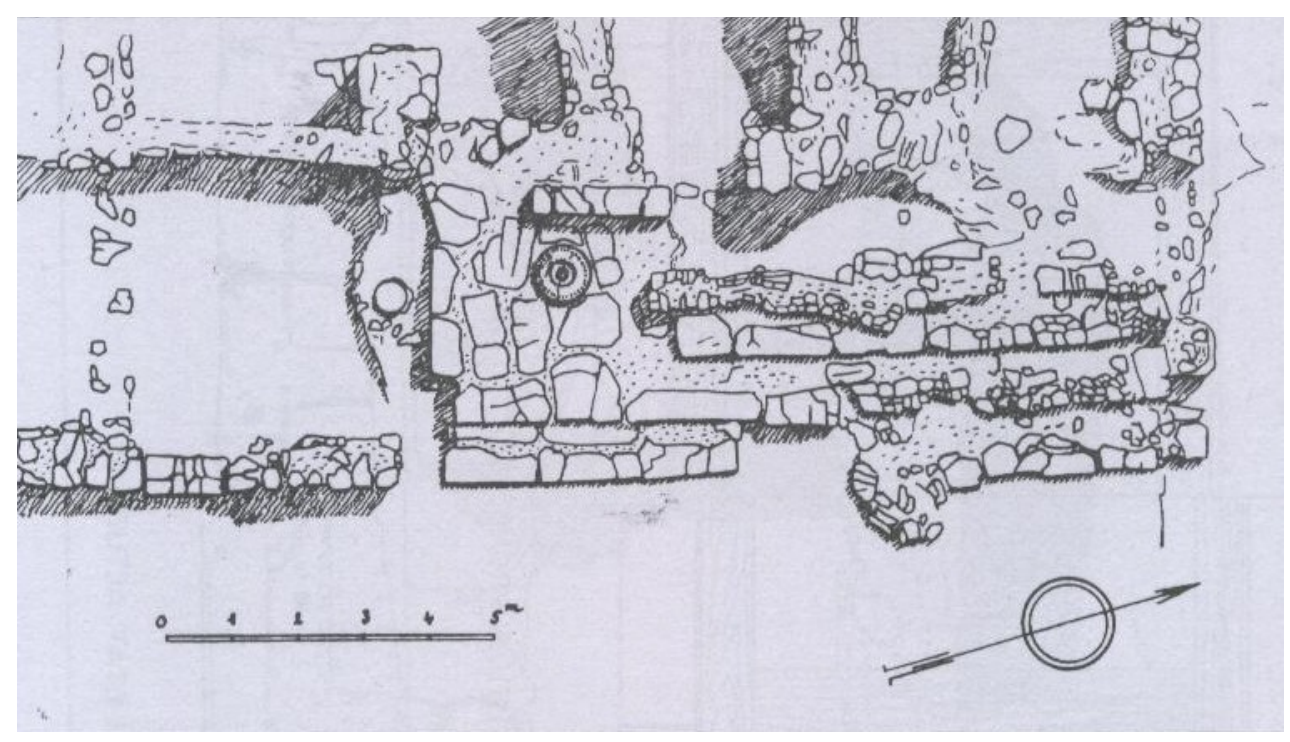

Fig. 75: Planta da escadaria Monumental (CHAPOUTHIER e JOLY, 1925-26, p. 14-18). 
A escada se compõe atualmente por quatro degraus em sideropetra, de comprimentos e profundidades diferentes. O primeiro degrau está separado por intervalo de 1,67 $\mathrm{m}$ onde poderia haver um pilar, agora inexistente. A parte norte desse degrau mede 4,72 m de largura com profundidade de $1,12 \mathrm{~m}$; a parte sul mede 4,67 m por 0,92 m. Diferença dada pela inclusão do terraço da peça XVI 1. Acima desse degrau há três outros que medem 8,30 de largura, com profundidade de $0,80 / 0,85 \mathrm{~m}$ e altura de $0,15 \mathrm{~m}$. Para além do último degrau a oeste, há uma espessa parede norte/sul da quadra XIX que faz o suporte do prolongamento da parte superior não conservada. Os compartimentos XIX 3 e 4, formariam a base do patamar dessa escadaria (PELON, 1980, p. 132-134).

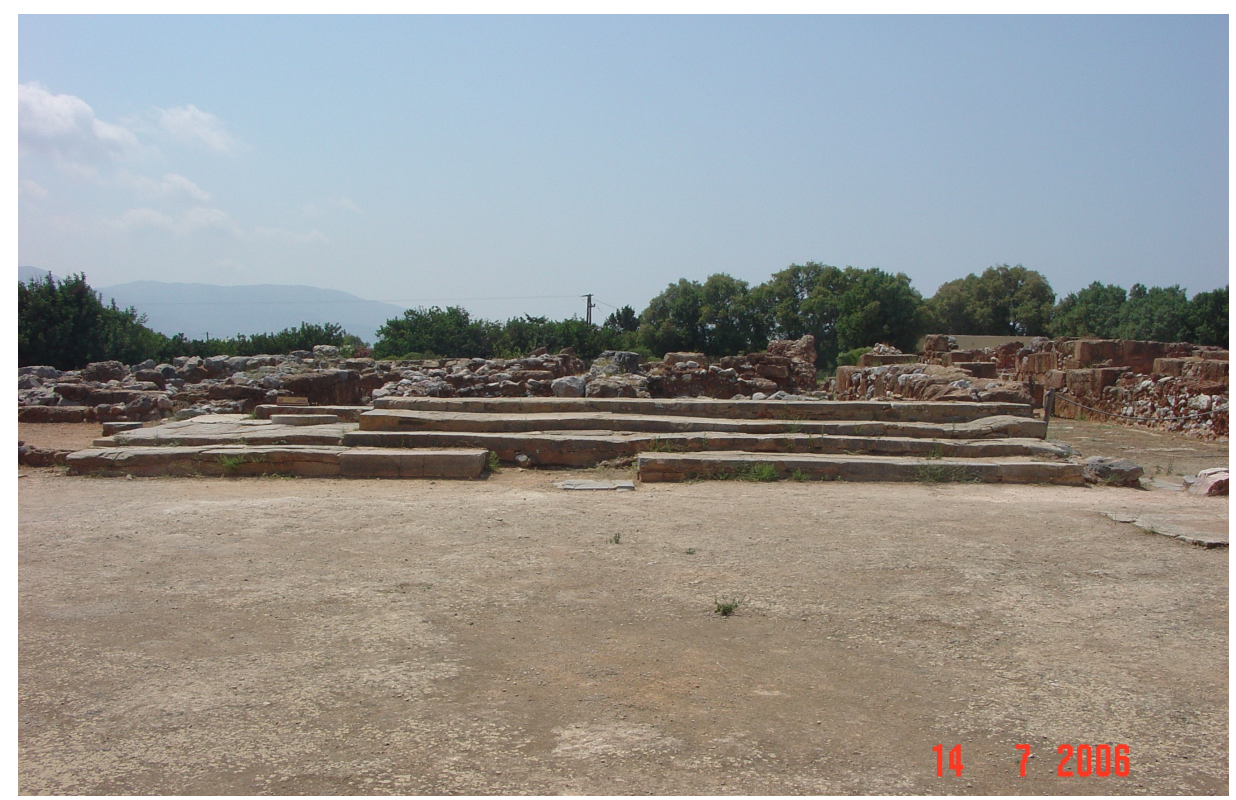

Fig. 76: Escadaria Monumental, vista do pátio central.

Assim como a Grande escadaria, a Monumental têm seu acesso visível pelo pátio central, podendo possuir inclinação de ângulo baixo. Contudo, para Pelon não existiria esse acesso, pois existiria uma parede entre o pátio central e a base da escadaria, se estendendo desde a quadra XVI, mas essa observação é discutível. Da mesma forma, sem os vestígios 
dos outros degraus não sabemos se ela possuía portas ou não, bloqueando o acesso. Mas pela sua extensa largura, parece que ela poderia fazer parte de rituais públicos, porque ela poderia suportar maior número de pessoas na sua circulação. Assim como esse mesmo número de pessoas também poderia circular no seu pavimento superior, pois as superestruturas do térreo oferecem condições de suportar cargas pesadas. Ela também poderia ser usada, pelo menos os seus primeiros degraus, como assentos para assistir os acontecimentos do pátio central.

Ela se configura como: fachada (interna), estético e de conexão. 


\section{Quadra IX}

A quadra se localiza na parte norte do pátio central, tendo como limites as quadra: XXI, ao norte; X e o Bastião E a leste; o corredor C1, a oeste. Compõem-se de quatro aposentos com dois acessos externos independentes que se abrem para a colunata norte do pátio central.

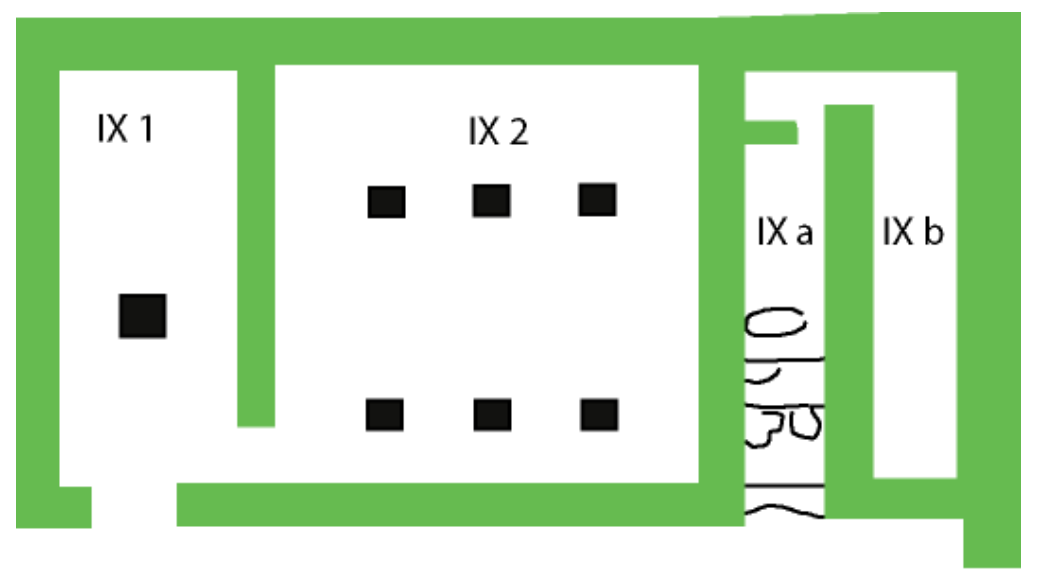

Pátio Central

Fig. 77: Quadra IX.

O primeiro acesso é através da sala IX 1, uma antecâmara da peça IX 2, que possui um pilar de ammouda no seu centro. Já a peça IX 2 consiste em uma sala cujas medidas são 9,40 x 9,05/9,03 m e é a mais ampla do palácio, possuindo uma área interna de $86 \mathrm{~m}^{2}$. No seu interior existem seis bases para pilares distribuídos em duas fileiras paralelas do sentido lesteoeste.

Chapouthier e Joly foram os primeiros a sugerir um pavimento acima da sala IX 2 , por causa da sua superestrutura, se baseando nas plantas de construções egípcias (1925-1926, p. 3-5). Porém, o primeiro a dar uma interpretação ao pavimento superior, foi Graham, 
chamando-a de sala de banquete (1962, p. 125-128).

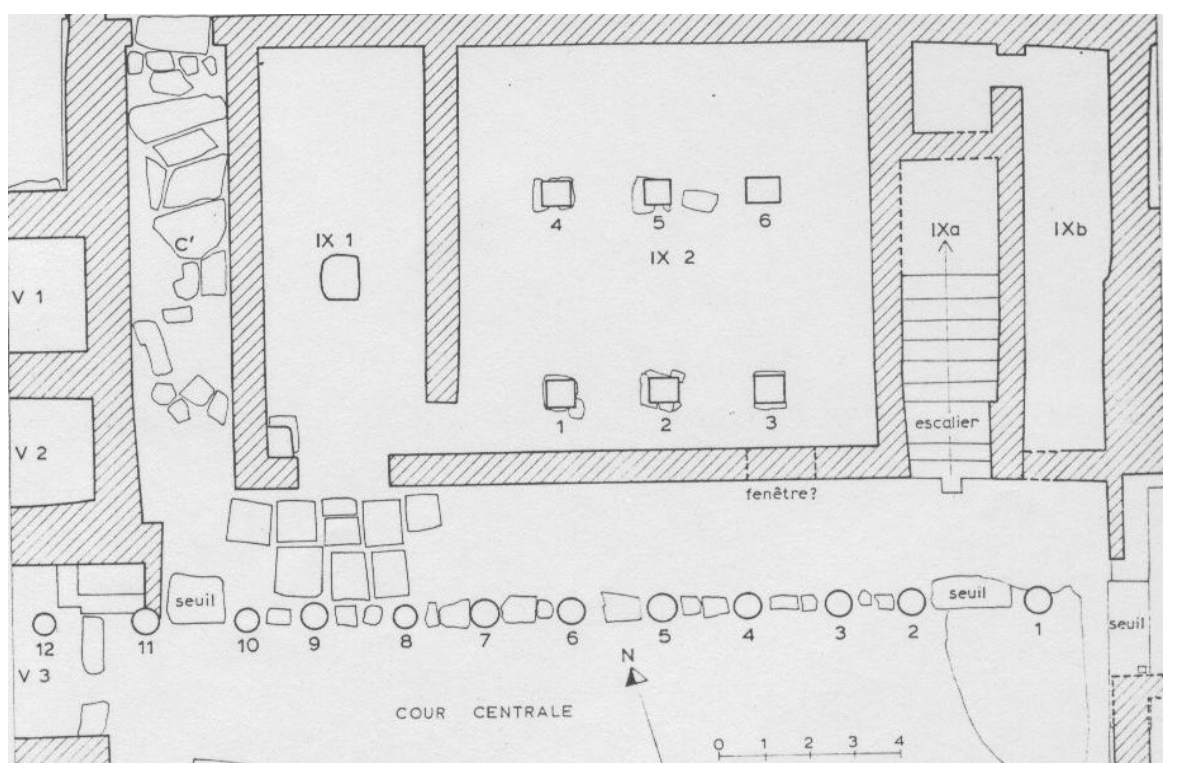

Fig. 78: Planta quadra IX (PELON, 1980, fig. 12).

Pelon, contudo, vai além e interpreta e sala do pavimento superior sendo de banquete com fundo religioso (PELON, 1980, p.190), além de redefinir o alcance e as dimensões do pavimento superior, que ele acredita estar apoiado pelos pilares do térreo e também pela parede sul das salas IX 1-2, o que permitiriam uma projeção da sala de banquetes para sul, até a colunata do pátio central.

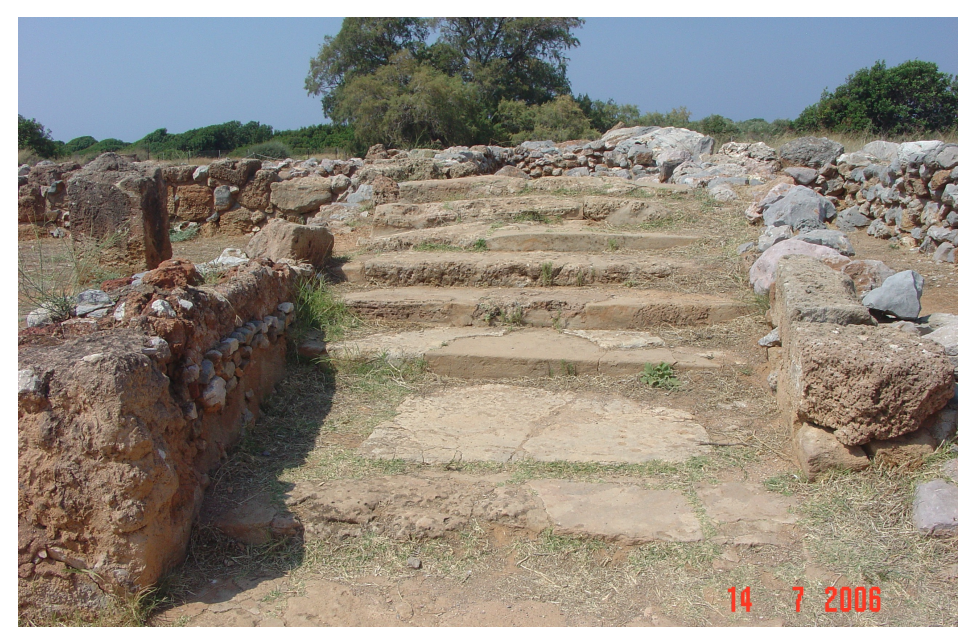

Fig. 79: Escadaria IX, vista do pátio central. 
O outro acesso se dá a leste da sala IX2. Este espaço abriga uma escadaria, tipo U, nas áreas IX a e IX b. A peça IXa mede 9,40 m de comprimento e 2,00 $\mathrm{m}$ de largura, tendo sua extremidade sul aberta ao pátio central e ocupada por oito degraus iniciais, que foram restaurados, com um comprimento total de 4,72 m. O primeiro degrau é uma laje de sideropetra que poderia fazer parte de um montante, com $0,70 \mathrm{~m}$ de largura. O restante dos degraus variam de 0,37 a $0,47 \mathrm{~m}$ de largura, por 0,11 a $0,16 \mathrm{~m}$ de altura, com $28 \%$ de inclinação, segundo Van Effenterre ${ }^{19}$ (1980, p.307). No extremo norte da peça há um muro de pedras para sustentação do conjunto e ligando à peça IX b. Sua aparência é semelhante ao da peça IX a. O restante da escadaria deveria ser de madeira. Um traço distintivo desta peça é a porção meridional da parede leste da sala IX $\mathrm{b}$, fronteira à peça $\mathrm{X} 4$, que possui uma espessura aumentada para $1,90 \mathrm{~m}$ ao invés da espessura média de $0,85 \mathrm{~m}$ em seu restante, junto ao bastião $\mathbf{E}$, o que sugere que pode ter sido usada de apoio estrutural à escadaria.

O número de degraus sugerido por Van Effenterre para esta escadaria é de 32 no total em sua reconstituição, que assim

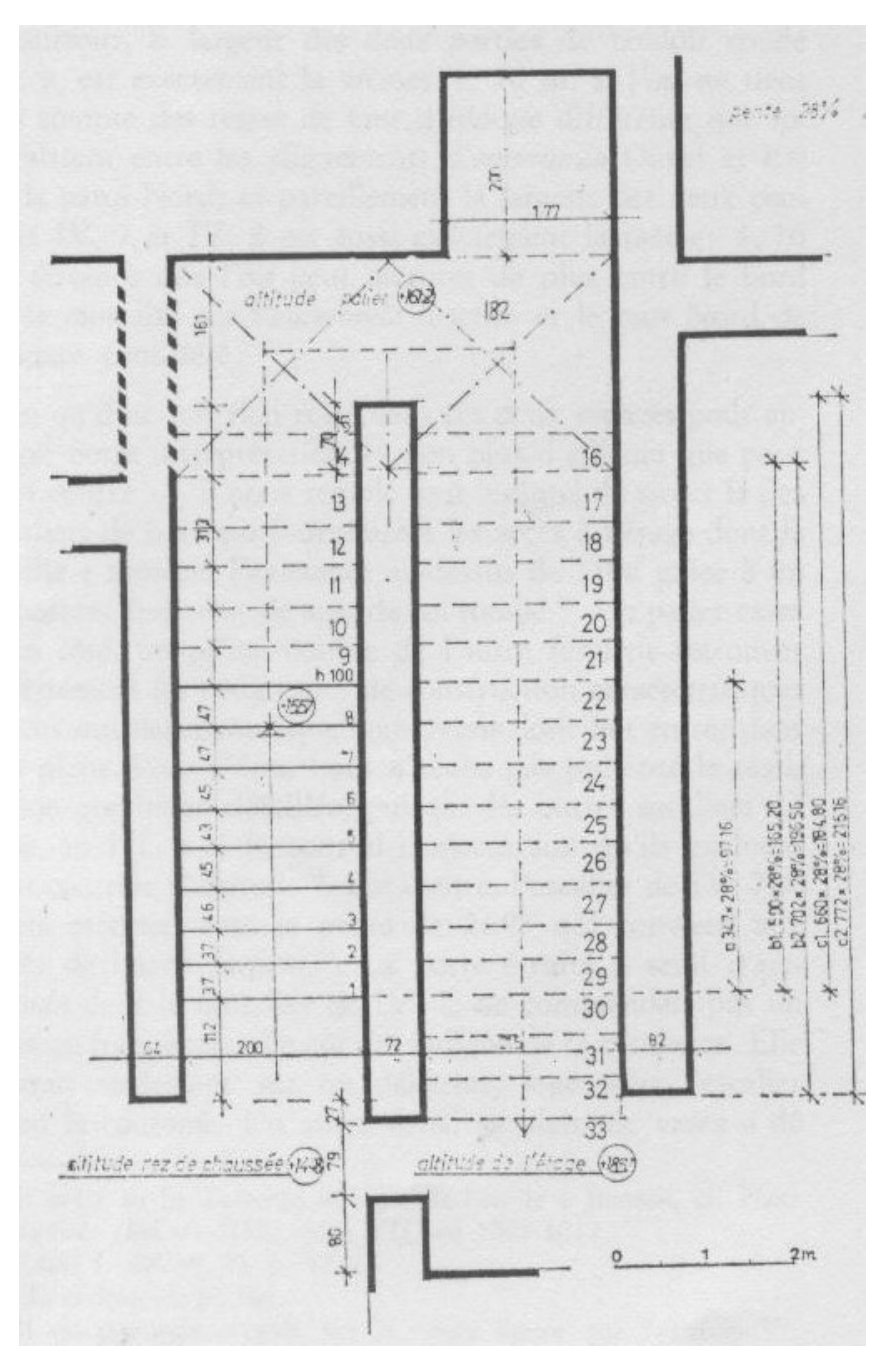

Fig. 80: Reconstituição da escadaria IX, segundo Van Effenterre (1980, fig.421).

19 A figura 421 de Van Effenterre (1980) indica a escadaria XXII, porém a imagem é da escadaria IX. Assim como, a figura 416 referente a escadaria IX na verdade é da escadaria XXII. 
indicaria uma altura de piso a piso de aproximadamente 5,00 m. Sua finalização no pavimento superior se daria muito próxima à parede externa que se abre para o pátio.

As peças IX a e b constituem uma peça única e não duas isoladas. A escadaria não apresenta qualquer comunicação perceptível com IX 1 e 2 , se destiva apenas ao acesso do pavimento superior, para a sala de banquete.

Apesar de não ser tão larga como a monumental, essa escadaria possui degraus de altura baixa, por onde podemos observar um acesso público também. Uma outra característica sua é o fato de não possuir vestígios de portas restringindo seu acesso. A interpretação de que seu pavimento superior serviria como sala de banquete é aceitável. Contudo, poderia servir de sala de recepção e banquete, mas aberta ao público. Como vimos a quadra possui superestrutura para apoiar, não só um como dois, pavimentos superiores, assim como, suportar uma carga de um número de pessoas mais elevado.

A escadaria se encaixa em dois elementos configuradores: fachada (interna) e de conexão. 


\section{Quadra XIII}

A quadra XIII, localizada no ângulo sudeste do palácio, é um conjunto de sete peças dispostas num padrão irregular, com acesso para o interior a partir do ângulo sudeste do pátio central e pela peça XIV 5, no ângulo sudoeste da quadra.

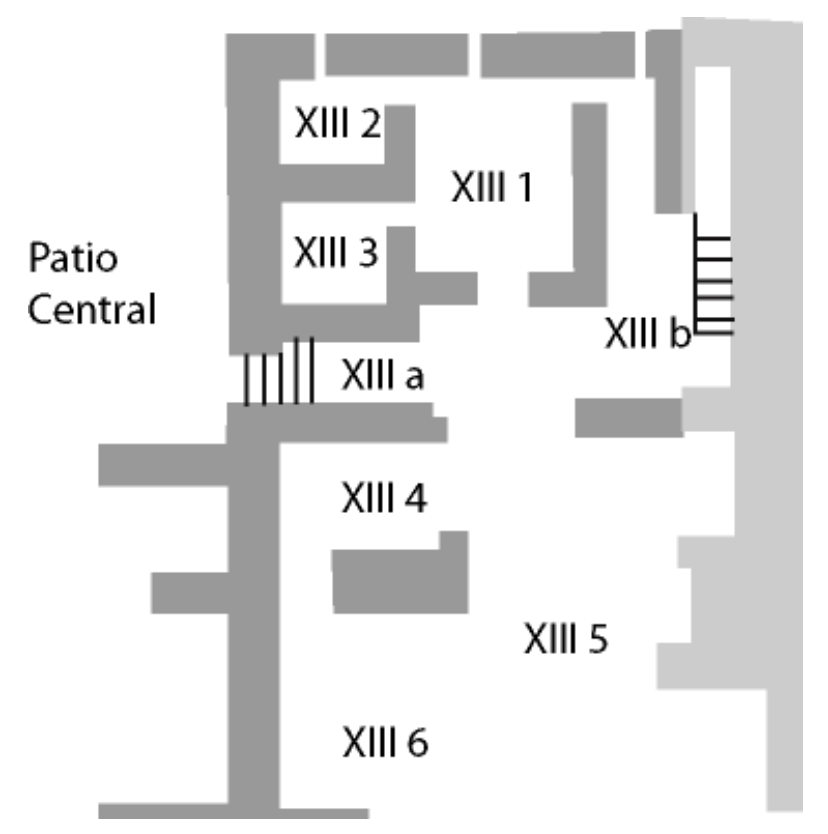

Fig. 81: Quadra XIII.

A entrada do pátio central apresenta-se como uma abertura cujo acesso se faz por uma escadaria de dois lances: um ascendente com três degraus que culminam em uma soleira que forma um patamar de $0,90 \mathrm{~m}$ de largura, situada a $0,60 \mathrm{~m}$ acima do nível do pátio central, e o outro descendente com dois degraus, que se estende do patamar até o interior da peça XIIIa, parte de um corredor em ângulo que se estende até a parede leste, onde temos a peça XIII b, ao lado de uma escadaria de acesso ao piso superior. (ALLEGRETTE, 1991 , p. 56)

A peça XIII b apresenta piso com algumas placas de xisto na base de um escadaria, sendo o resto de terra batida. A escadaria, tipo $\mathbf{U}$, consiste de cinco degraus 
conservados de ammouda que provavelmente se prolonga até o pavimento superior. Os degraus têm por volta de $0,35 / 0,40 \mathrm{~m}$ de comprimento, por $0,90 \mathrm{~m}$ de largura e altura de 0,36 $\mathrm{m}$. Seu total de degraus preservados ocupa um espaço de $1,80 \mathrm{~m}$.

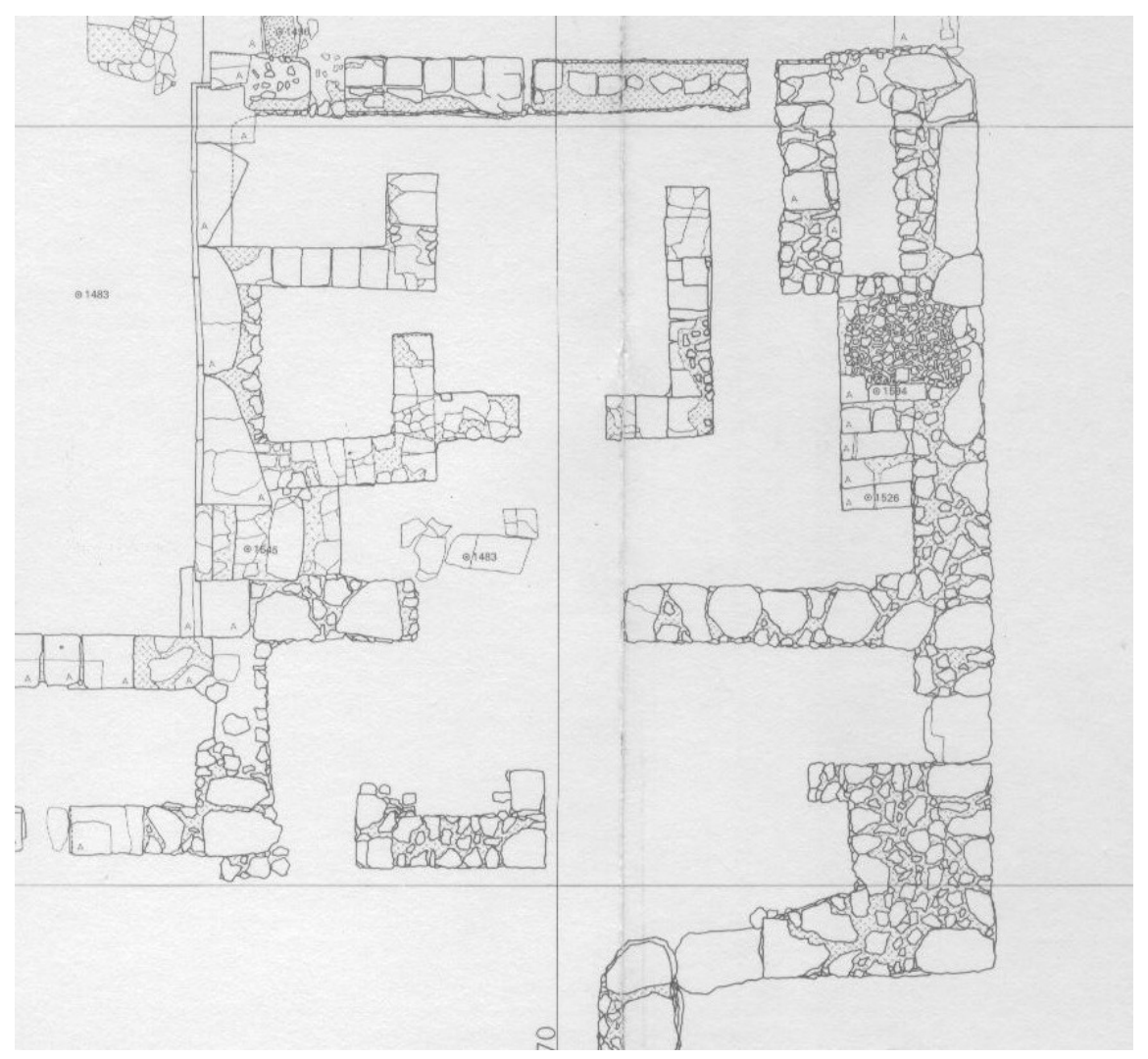

Fig. 82: Planta da quadra XIII (MALLIA, 1974).

A escadaria ao lado de XIII b sugere a presença de um pavimento superior. Entretanto, como Pelon apontou, a estrutura desta quadra é muito frágil para suportar um pavimento construído como ocorre nas quadras do setor oeste (quadras I, VI, VII e VIII) sendo mais correto crer em uma espécie de terraço ou varanda (PELON, 1980, p.206). Essa opinião de Pelon se funda no fato da quadra não possuir contrafortes ou pilares, mas as salas têm espaços pequenos com paredes divisórias que ajudariam a suportar um piso superior, mais do que um terraço, como veremos na quadra XXVII.

Pelon sugere que esta quadra poderia ser destinada a fins habitacionais, por apresentar um plano que inclui uma peça central, um corredor angular e anexos, o qual se 
assemelharia ao de um bloco de habitação (PELON, 1980, p.207). Alegrette acredita que esses traços não são suficientes para tal identificação (ALLEGRETTE, 1991, p.57).

Para Van Effenterre, a escadaria teria uma inclinação de 49\%.

A grande diferença dessa escadaria para as outras primeiras apresentadas é sua situação.

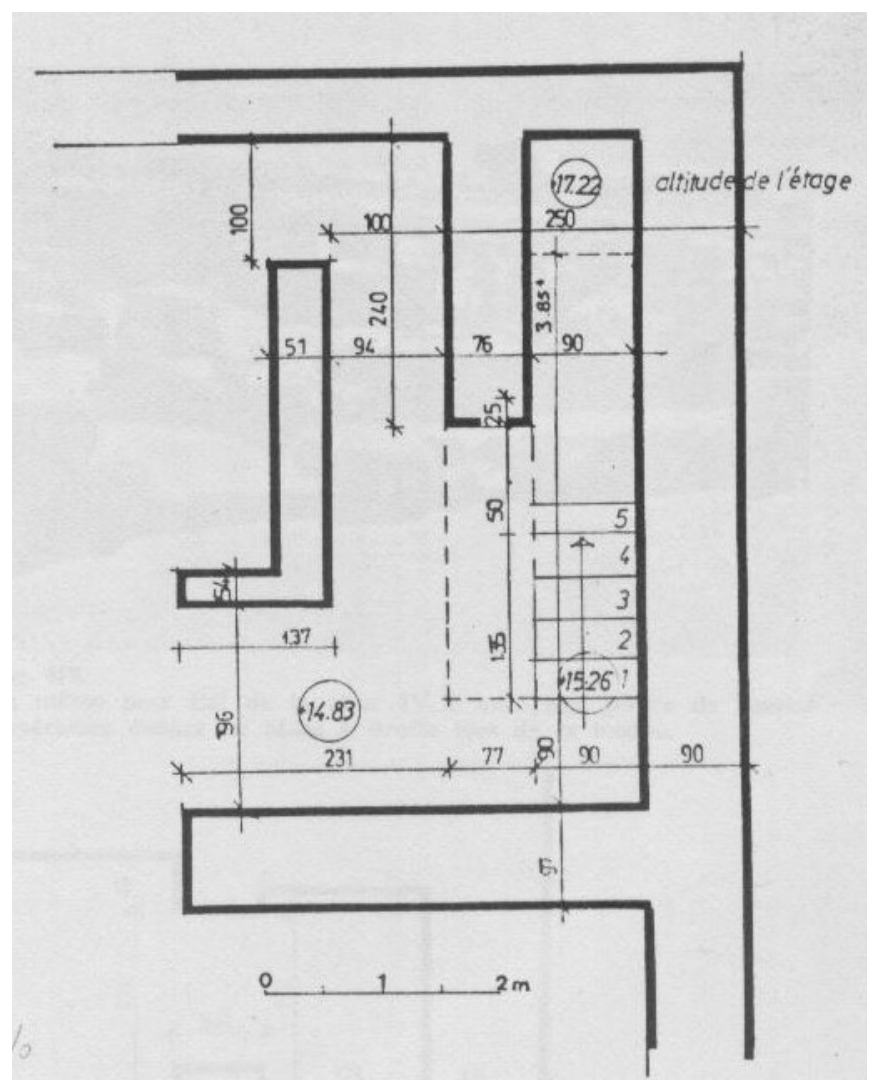

Fig. 83: Reconstituição escadaria XIII, segundo Ven Effenterre (1980, fig.417).

Ela localiza-se em um ambiente fechado e em uma quadra pequena. Sua inclinação, como Van Effenterre sugere, é de um ângulo maior, pois como foi apontado anteriormente, quanto maior a inclinação menor o espaço a escada ocupará e mais esforço físico é necessário. Sua largura é estreita comparada às outras sugerindo um acesso mais restrito ainda. A escadaria, portanto, teria uma função de passagem e comunicação mais 
privada. Sua conexão ao pavimento superior poderia dar-se às quadras XIII, XIV e XV. A escadaria apresenta elementos configuradores: fachada (tanto externa, como interna) e de conexão. 


\section{QUADRA XVII}

Paralelo ao corredor da entrada sul do palácio localiza-se a quadra XVII, que se compõe de quatro peças e duas escadarias. Limita-se com as quadras XIX ao norte, XVIII a oeste, e a entrada sul a leste.

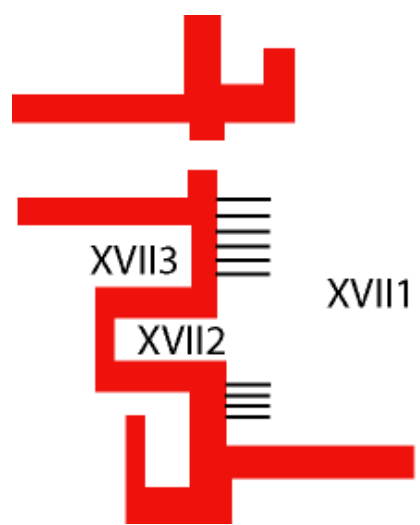

Fig. 84: Quadra XVII.

A peça XVII 1 não apresenta comunicação direta com a sala XVII 2 a oeste. A peça XVII 2 está em um nível inferior do solo, apresenta um desenho tipo T, onde possui duas escadarias e uma sala. A primeira escadaria dessa peça está a sul com dois degraus ascendentes e um patamar no seu final. A escadaria não apresenta acesso a lugar algum. Entretanto foram encontrados vasos de cerâmica, de pedras inteiros e inacabados, sugerindo a destinação da peça XVII2 como uma oficina, portanto seu acesso deveria ser pela peça XVII 1, usando a escadaria de desnível para atingir a peça XVII 2, mas atualmente sua passagem não é clara.

Já a escadaria norte está "de costas" para escadaria sul e parece que se conectaria à peça XVII 3 pelo piso superior (CHAPOUTHIER e DEMARGNE, 1929-1935 e 1946-1960, p.8). A escadaria possui cinco degraus in loco, se apoiaria na parede paralela da quadra ao 
lado, XVIII 4, em seus grandes blocos brutos de ammouda e sideropetra e seguiria para o segundo pavimento com o restante dos degraus em madeira até a esquina da parede divisória da peça XVII 2, total de 4,00 m de comprimento, tipo I.

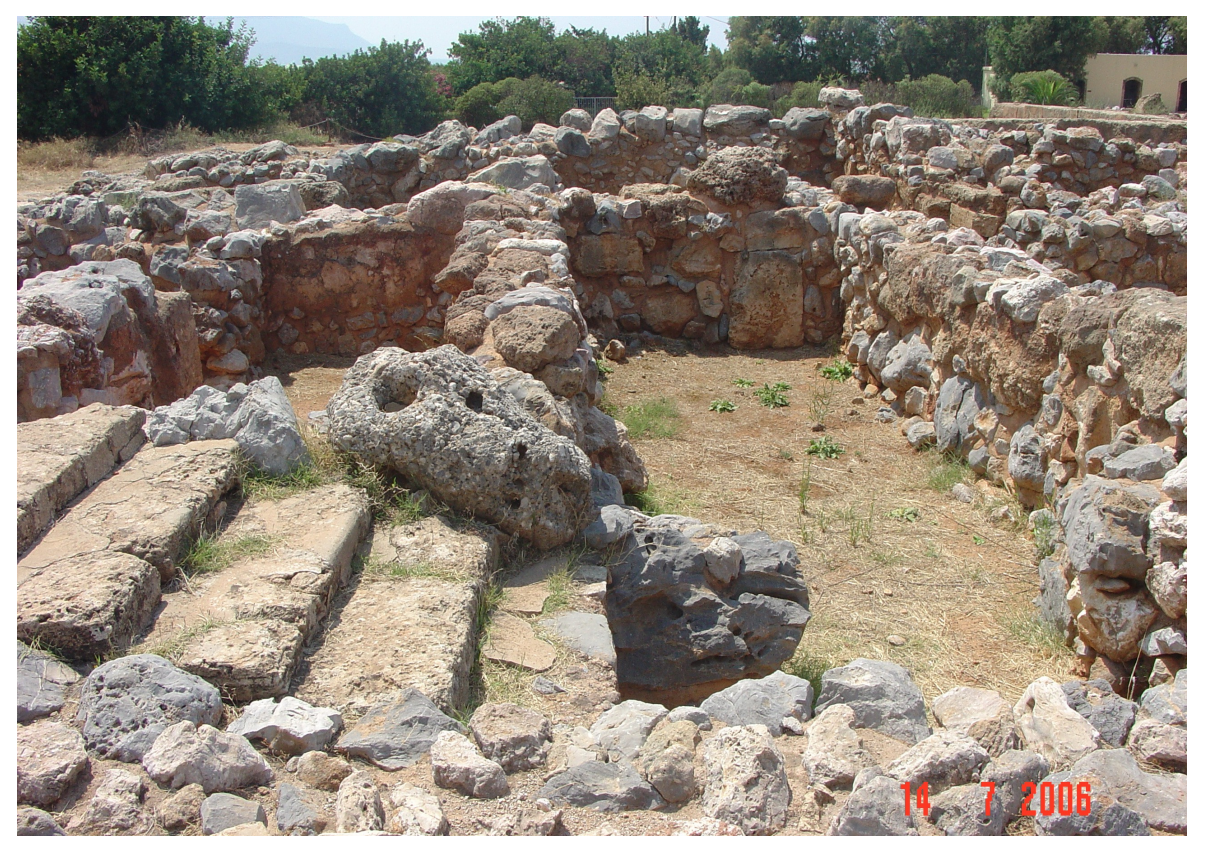

Fig. 85: Quadra XVII, escadaria norte.

A peça XVII 4 não possui acesso da peça XVII 3, talvez sua função seria somente de apoio, como analisaremos na quadra XIX.

A escadaria norte se configura como sendo de fachada, conexão e sua função é restrita. 


\section{Quadra XIX}

Localizada na parte oeste do palácio, se encontra parcialmente destruída, limitando-se ao norte com a quadra VII, a leste com a escadaria monumental, quadra XIX e a quadra XVI, ao sul com a quadra XVII e a oeste com a quadra XX e o bastião H. Compõe-se de dez peças distribuídas em um padrão irregular, com ausência de comunicação entre partes da quadra, resultando em grupos distintos de peças.

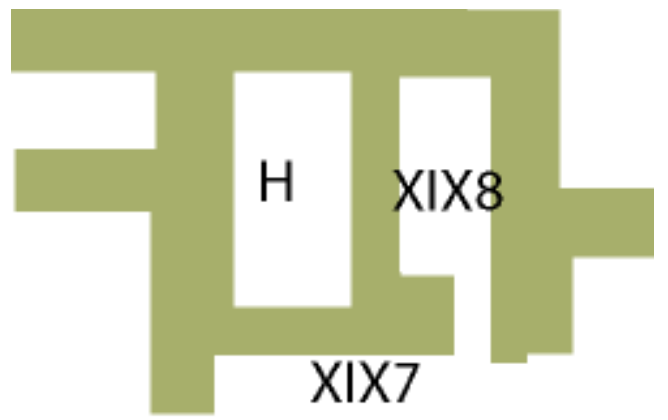

Fig. 86: Quadra XIX, peças XIX 7, XIX 8 e bastião $H$.

A suposição dessa quadra seria somente de suporte para os pisos superiores. São três os indícios que nos apoiamos. Primeiro, pela sua restrição dessa quadra de acesso ao piso inferior. Segundo, existe uma superestrutura devido às espessas paredes, que medem de 0,90 $\mathrm{m}, 1,50 \mathrm{~m}$ e chegam até $1,80 \mathrm{~m}$, em volta das peças XIX 7 e 8 e o bastião H. Terceiro, as saliências nas paredes dos corredores ao norte XXI 9 e 10 e quadra XX.

O acesso ao piso superior deveria ser através da escadaria Monumental, e a escadaria que levaria aos outros pisos se localizaria acima da peça XIX 8, que possuem dimesões de 4,50 m x 2,00 m, sendo de tipo $\mathbf{I}$.

Ao contário da quadra XVII, ela não seria restrita, porque não estaria conectando a espaços pequenos e pelo fato de na escadaria monumental não existir nenhum indício de 
portas.

Ela se configura nos elementos de conexão e fachada. 


\section{Quadra XXI}

A quadra XXI se localiza na porção norte do palácio, seu acesso é ao sul pelo corredor $\mathrm{C}^{\prime}$ do pátio central, limitando-se ao norte a quadra XXII e ao pátio norte, a leste o bastião $\mathrm{D}$ e a oeste o pátio noroeste e a quadra $\mathrm{V}$.

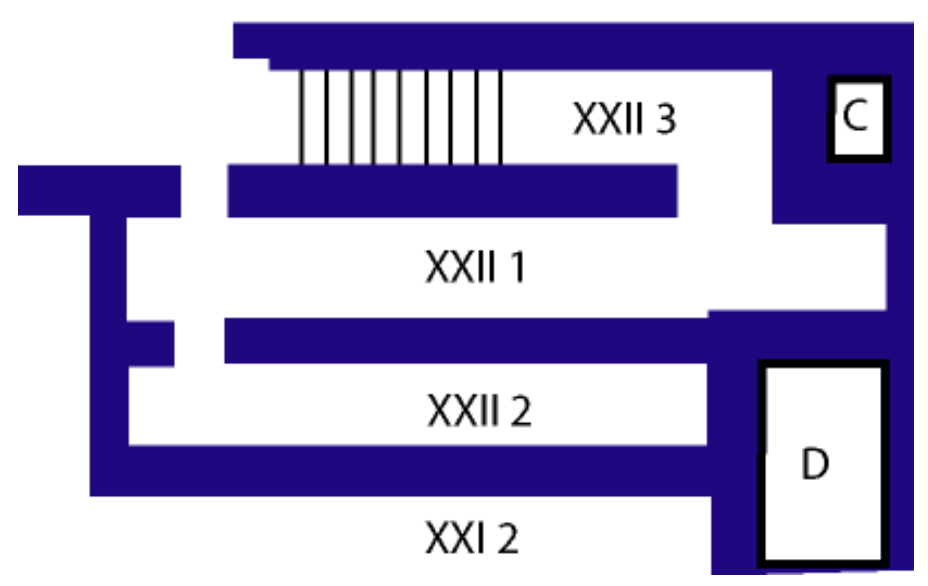

Fig. 87: Quadras XXI e XXII. 


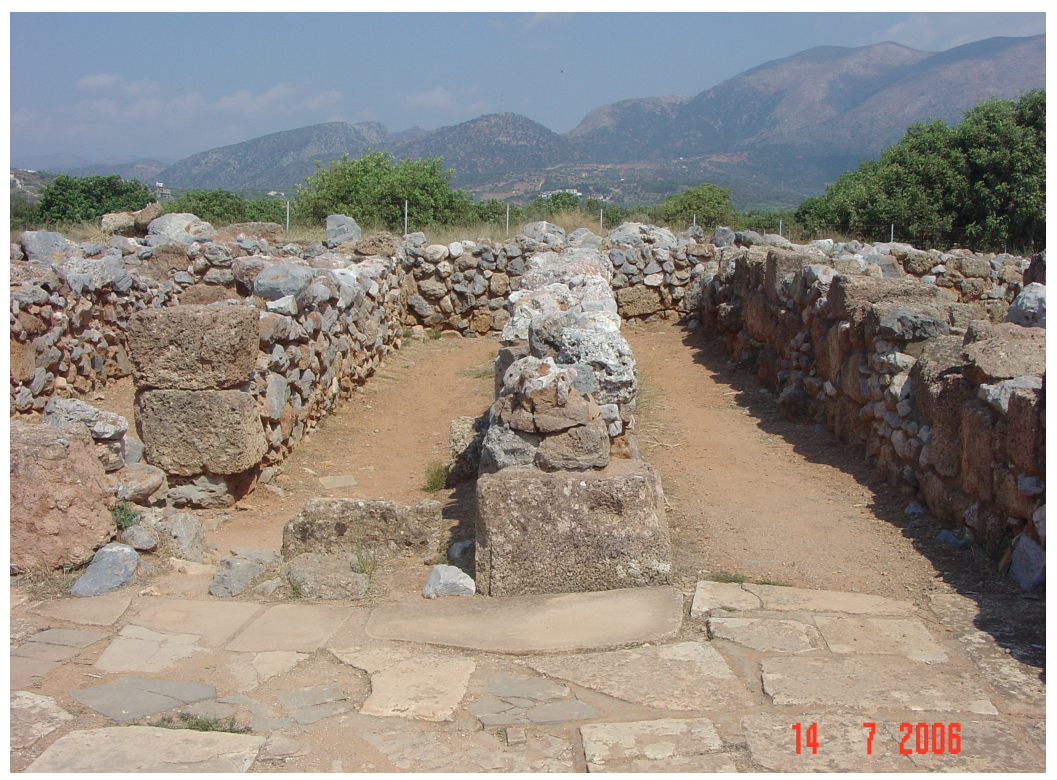

Fig. 88: Peça XXII 2, à esquerda e à direita XXI 2.

Graham acredita que essa área fosse destinada para estocagem no piso térreo e que a parede ao norte se elevava até o pavimento superior. $\mathrm{O}$ andar acima se comunicaria ao pavimento superior da área XXII, estabelecendo, um poço de uma escadaria tipo $\mathbf{U}$, que se conectaria ao terceiro pavimento, o terraço (GRAHAM, 1979, p.68).

Esse tipo de articulação não é excepcional na arquitetura minóica; não há evidências diretas, mas temos indícios de que poderiam ser dessa maneira. Se analisarmos escadarias construídas acima de escadarias veremos que elas são possíveis, mas que se tornariam muito pesadas e perigosas em lugares sujeitos a tremores terrestres, como é o caso de Creta. Portanto, seria mais prudente nas construções com escadarias de grande porte que estas fossem paralelas. As diferentes quadras (IX, XXI, XXII e XXVI) que compõem o piso térreo do palácio no setor norte configuram um bloco articulado no pavimento superior.

Se configura como elementos de fachada e conexão. 


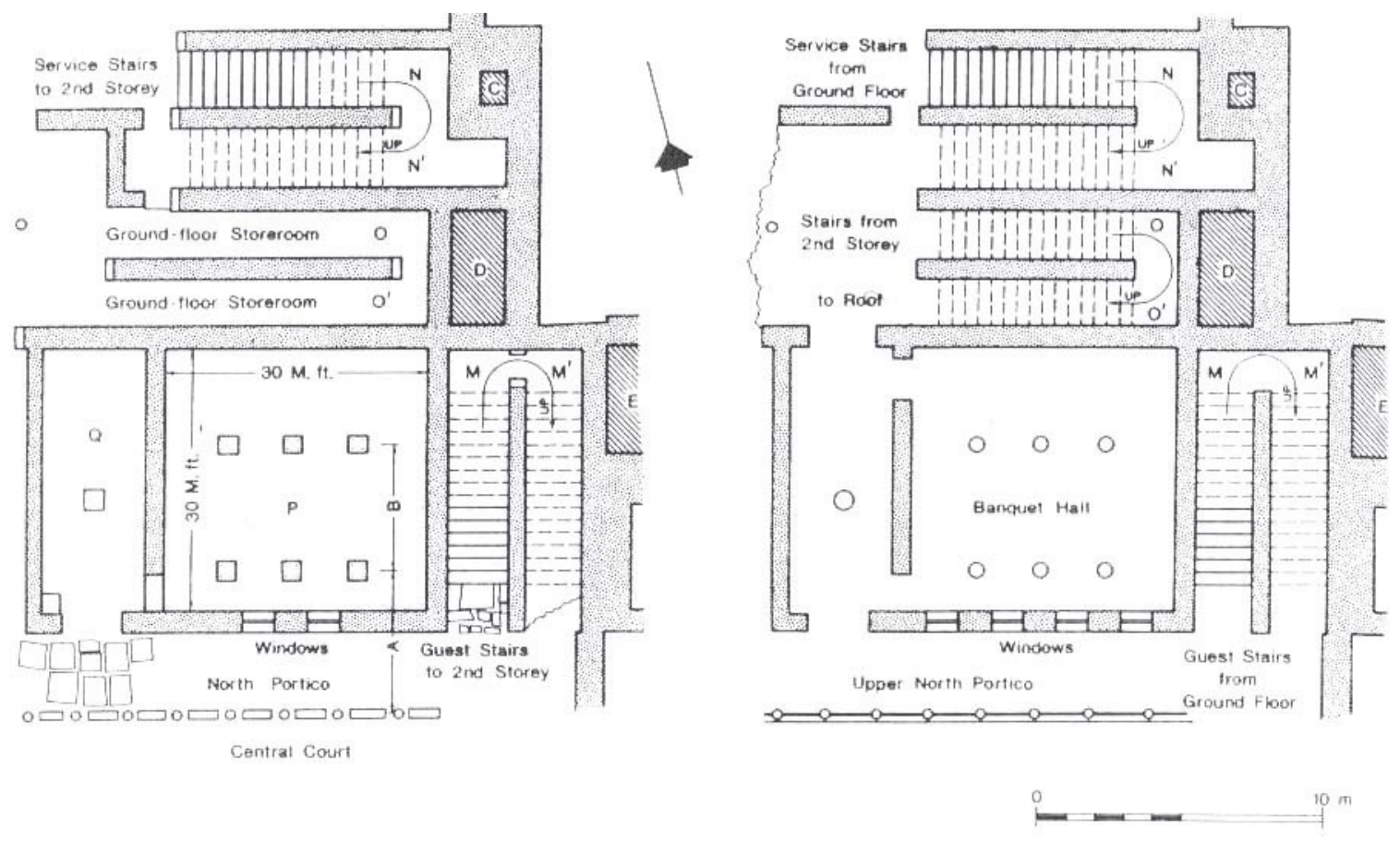

Fig. 89: Proposta, segundo Graham, do pavimento superior e suas respectivas escadarias, acima das quadras IX, XXI e XXII, os acessos à sala de banquete (1979, ILL.8). 


\section{Quadra XXII}

A quadra XXII localiza-se paralelo a sul da quadra XXI, a leste do bastião C, a norte a quadra XXIV e a oeste do pátio norte.

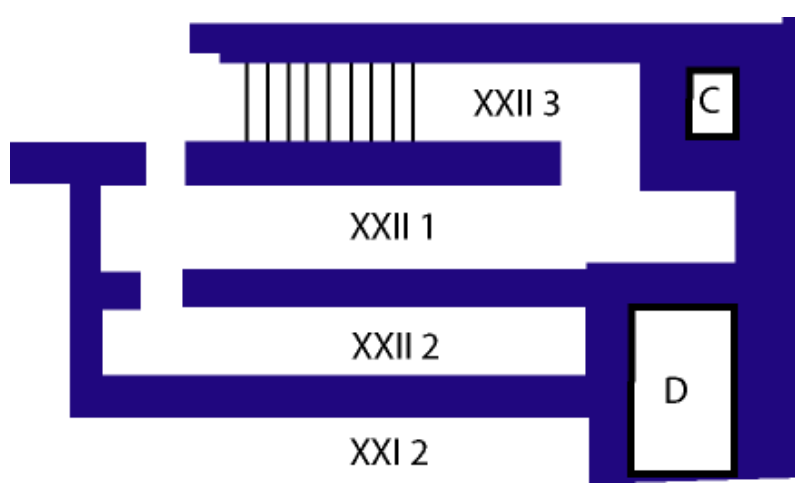

Fig. 90: Quadras XXI e XXII.

No espaço XXII 3 existe uma escadaria em ótima conservação com os oito primeiros degraus em ammouda preservados, totalizando uma altura de 1,10 $\mathrm{m}$. Suas dimensões são: 2,00 m de largura, por 0,44 de comprimento e 0,14 de altura média dos degraus. Sua base sólida é de cascalho e com o suporte do muro ao sul é possível que ela contornasse, sendo ela do tipo $\mathbf{U}$, e se ligasse ao pavimento superior pelo corredor XXII 1 . Essa escadaria é muito similar a IX mas seu acesso é através do pátio norte.

Graham sugere quinze degraus para cada lance e um patamar entre eles (GRAHAM, 1962, 183), enquanto Van Effenterre sugere 16 para o primeiro lance, e dezessete para o segundo, possuindo um patamar entre eles também (EFFENTERRE, 1980, p.309). Contudo, é um grande número de degraus para essa escadaria. Mas, tanto Graham 
como Van Effenterre acreditam que nessa parte do palácio o pé direito seria de 4,50 $\mathrm{m}$ de altura de um piso a outro.

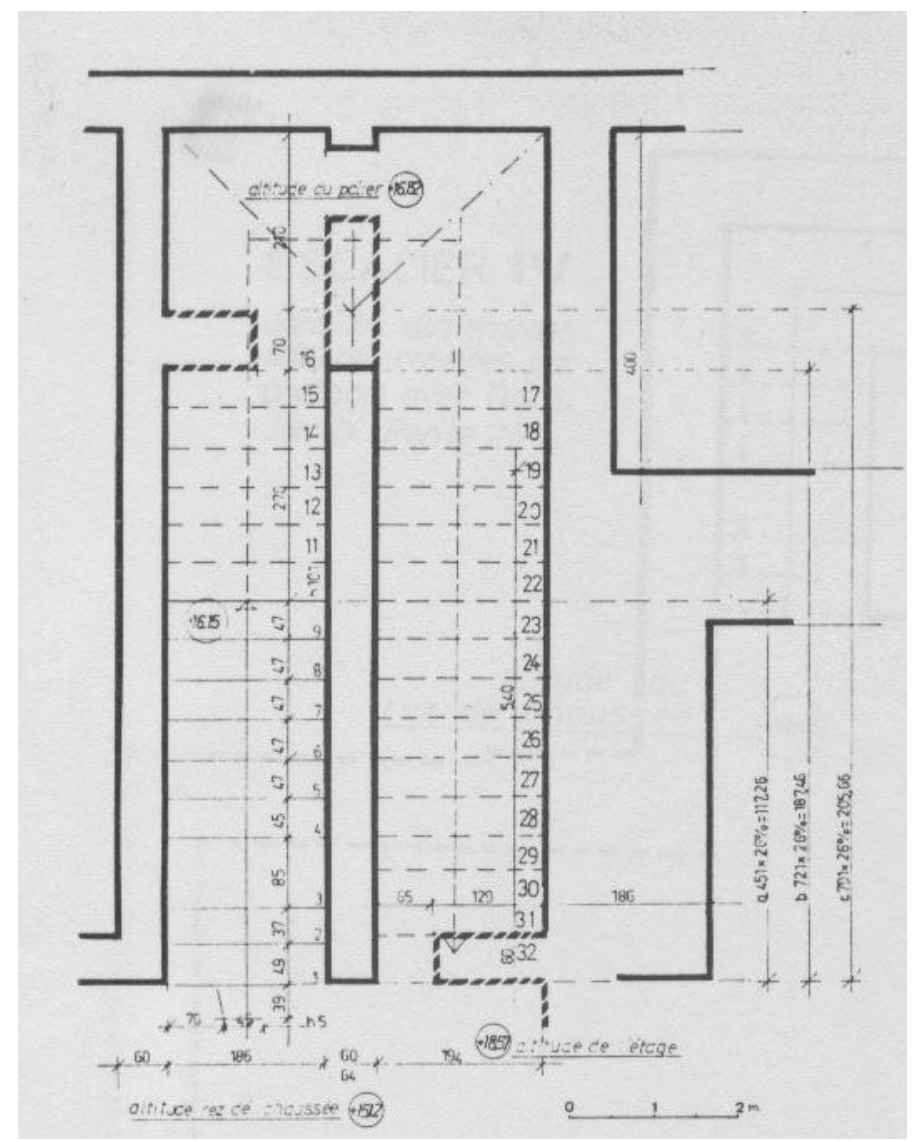

Fig. 90: Planta reconstituição, segundo Van Effenterre (1980, fig.416).

Para Graham, a escadaria conectaria também a sala de banquete, contudo, ela teria uma função de serviço, pois está mais próxima da cozinha na quadra XXV. (fig.89)

A escadaria apresenta elementos configuradores: fachada, conexão e função. 


\section{Quadra XXVII}

A norte do palácio, a quadra se encontra isolada do resto do edifício, se compõe de seis peças alinhadas paralelamente de leste a oeste, acessíveis por aberturas na sua face sul, exceto a sala XXVII 6, o restante serviria de depósitos.

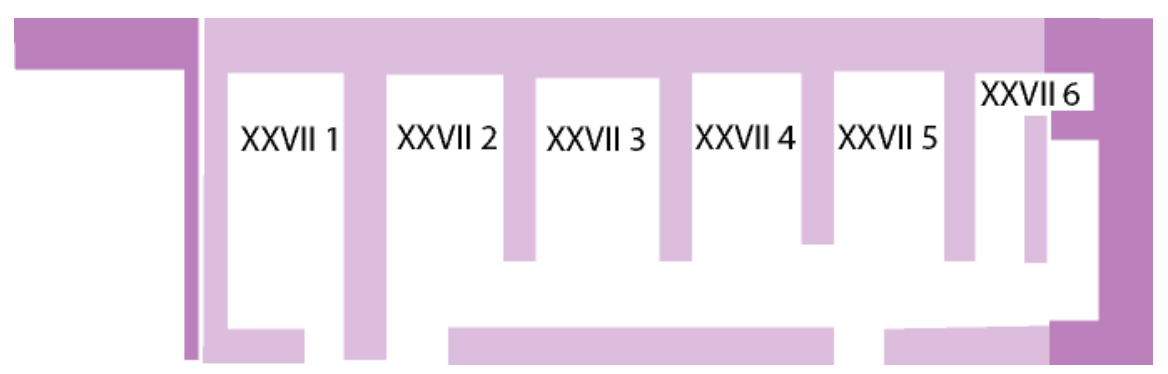

Fig. 91: Quadra XXVII.

A sala XXVII 6 possui uma estrutura retângular medindo 2,05 x 1,35 m apoiado na parede leste e aberto ao sul. Nesse espaço foi encontrado um preenchimento com fragmentos cerâmicos. Para Chapoutier e Demargne nesse espaço haveria um forno (1942, p.16). Mas para Van Effenterre, possuiria uma escadaria, tipo $\mathbf{U}$, que conectaria a um terraço no pavimento superior (EFFENTERRE, 1980, p.310). Segundo, o pesquisador a escadaria possuiria um total de vinte e quatro degraus. O primeiro lance teria 1,00 m de largura e $0,35 \mathrm{~m}$ de comprimento para cada degrau, possuindo doze degraus no total. E o segundo lance, igual ao primeiro, possuiria também 1,00 de largura e um patamar intermediário entre os lances, se assemelhando à escadaria da quadra XIII e contendo a mesma inclinação, $49 \%$. 


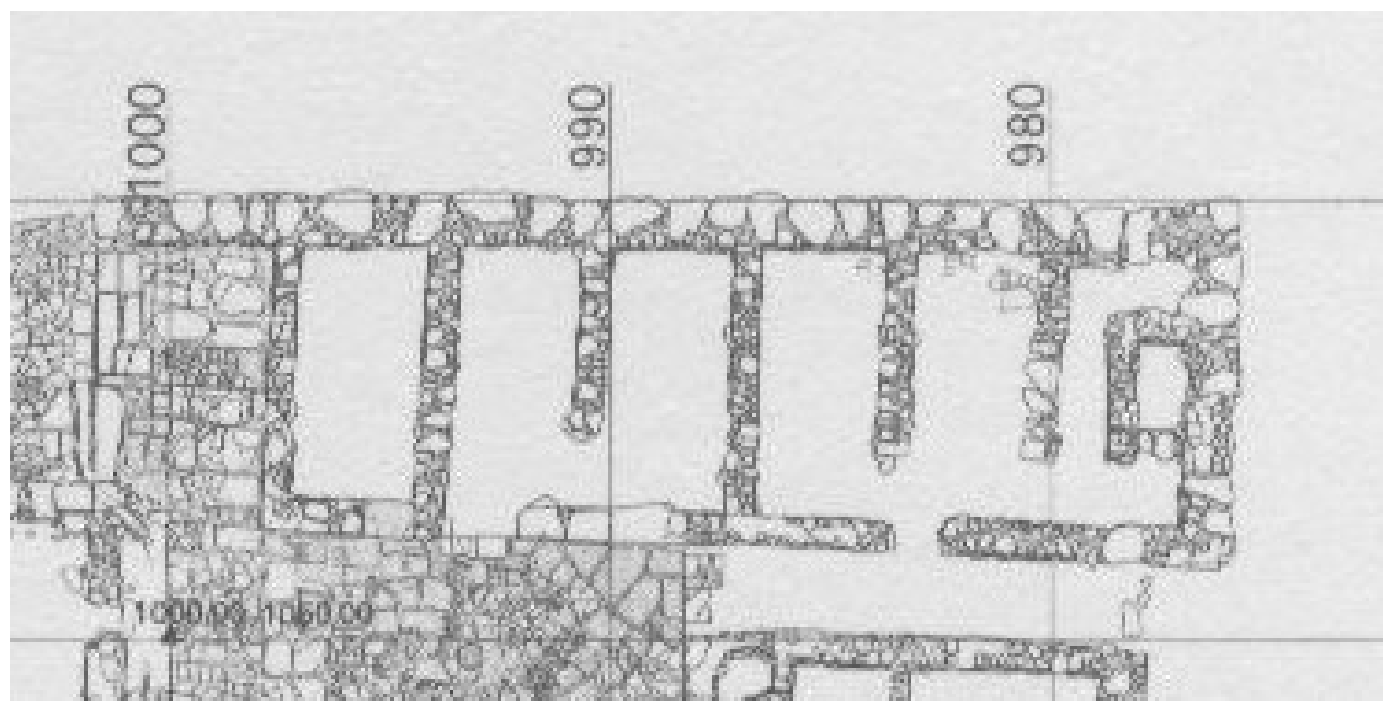

Fig. 92: Quadra XXVII (MALLIA, 1974).

Pela estrutura da quadra, pelas paredes paralelas e muros espessos onde a escadaria se apoiaria, seríamos levados a acreditar que ela teria condições de suportar um pavimento superior, leve, como um terraço. A escadaria possui as mesmas propriedades e elementos configuradores da escadaria da quadra XIII, sendo ela restrita e apontando como elemento de conexão e de fachada. 


\section{ANÁLISE GERAL}

Partiremos agora para a compreensão do papel do elemento vertical na percepção do espaço minóico, a tridimensionalidade e situação na organização dos edifícios, suas restrições e possíveis funções do elemento, para assim entender o dinamismo das construções numa visão tridimensional do uso do espaço e verificar a existência de padrões no uso dos elementos verticais. É a partir dessa análise da verticalização dos edifícios das cidades minóicas, em um olhar micro-espacial, que se chegará a outro de maior escala, o urbanismo, o planejamento, e a relação com a ampliação das cidades nesta direção. Cabe aqui fazer as referências de outros sítios das cidades das ilhas de Creta e Tera datadas do mesmo período.

Nesse momento também iremos fazer uma discussão complementar de análise de campo, do catálogo elaborado e das reconstruções que foram feitas em algumas construções da cidade de Mália.

Foram catalogadas 31 escadarias que conectam uma pavimento a outro. Primeiramente, verificamos que estas três formas das escadas, tipo $\mathbf{I}, \mathbf{L}$ e $\mathbf{U}$, são usadas nos edifícios. Elas aparecem tanto nas construções privadas como nas públicas.

As escadarias tipo U são encontradas nas construções Delta Alfa (1), Épsilon (2), Casa Mu A (1), Cripta Hipostila (1), nas quadras do palácio I, II, IV, IX, XIII, XXI, XXII e XXVII, dando um total de 13 escadas nesta forma.

As escadarias tipo I são em número similar as do tipo $\mathbf{U}$. As escadarias de tipo I são encontradas nas construções Zeta Beta (1), Delta Beta - bloco leste (1) e bloco central (1), Casa Mu A (2), Casa Mu B (2), Épsilon (1, entrada secundária) a Escadaria Monumental, a Grande escadaria, XVII e na XIX do palácio, totalizando 12 escadarias nesta forma.

Por fim, as do tipo L, são encontradas nas construções Zeta Alfa (1), Zeta Beta 
(1), Delta Beta - bloco oeste (1), Casa Mu A (1) e Cripta Hipostila (2) com um total de 6 escadarias. O palácio não possui escadaria desse tipo.

Portanto, quanto a um padrão nas formas das escadaria, verificamos que o total para cada uma delas é muito parecido para dois tipos: U (13), I (12), porém, entre esses dois tipos há uma predominância do tipo $\mathbf{U}$ no palácio. A preferência desses dois tipos é nítida na sua quantificação, enquanto as escadarias tipo L (6) é bem menor e não possui indícios desse tipo no palácio.

Todos esses tipos de escadaria aparece também nos palácios de Cnossos, Festos, nas residências da ilha de Creta, assim como em Acrotiri.

Nas reconstituições do arquiteto Schmid para as oficinas da quadra $\mathrm{Mu}$ são sugeridas várias escadarias para cada uma delas. Na oficina de cerâmica, que possui uma área total de $79,00 \mathrm{~m}^{2}$, ele sugere quatro escadarias de um piso a outro (sendo que três seriam tipo U, uma acima da outra ocupando o mesmo vão, VIII C, como uma espiral, do subsolo ao piso térreo, do térreo ao piso superior e do piso superior ao terraço) e uma do tipo I também que levaria ao subsolo, ocupando a área VIII B. Além de três escadarias de desnível (duas no pavimento térreo e a última no terraço). A reconstituição de Schmid teria então quatro andares no total. Entretanto, tal interpretação não é plausível. Primeiro, porque no espaço do vão das supostas escadarias em "espiral” de tipo U não possui uma parede divisória que comumente ocorre nos vãos dessa forma. A peça que fica entre o vestíbulo e a sala VIII 5, cujas dimensões são de 2,00 m de largura por 3,00 m de comprimento, seria somente uma sala entre as peças no seu entorno. Essa parede divisória seria muito importante para suportar uma escadaria que seguiria quatro andares. Segundo, as espessuras das paredes nessa peça são de apenas $0,40 \mathrm{~m}$, enquanto no restante do edifício em algumas salas chegam até $0,70 \mathrm{~m}$, mas não estão próximas ao vão sugerido por Schmid. Para a área VIII B onde Schmid sugere uma 
escadaria tipo I, ligando o piso térreo para o subsolo, também não existe nexo. Não possuimos muitos dados sobre as alturas do piso. A escavação chegou até o chão do piso térreo, e pela planta do edifício em seu estado atual, não pela reconstituição, veremos a entrada principal pela área VIII B, não pelo vestíbulo VIII 1. Dessa maneira, desconsidero todas as as sugestões de escadarias propostas para essa oficina. O restante das escadarias de desnível seria possível porque as áreas VIII 1 e VIII 2 estão a $0,50 \mathrm{~m}$ do nível do piso enquanto o restante está a 0,84 chegando até $1,00 \mathrm{~m}$.

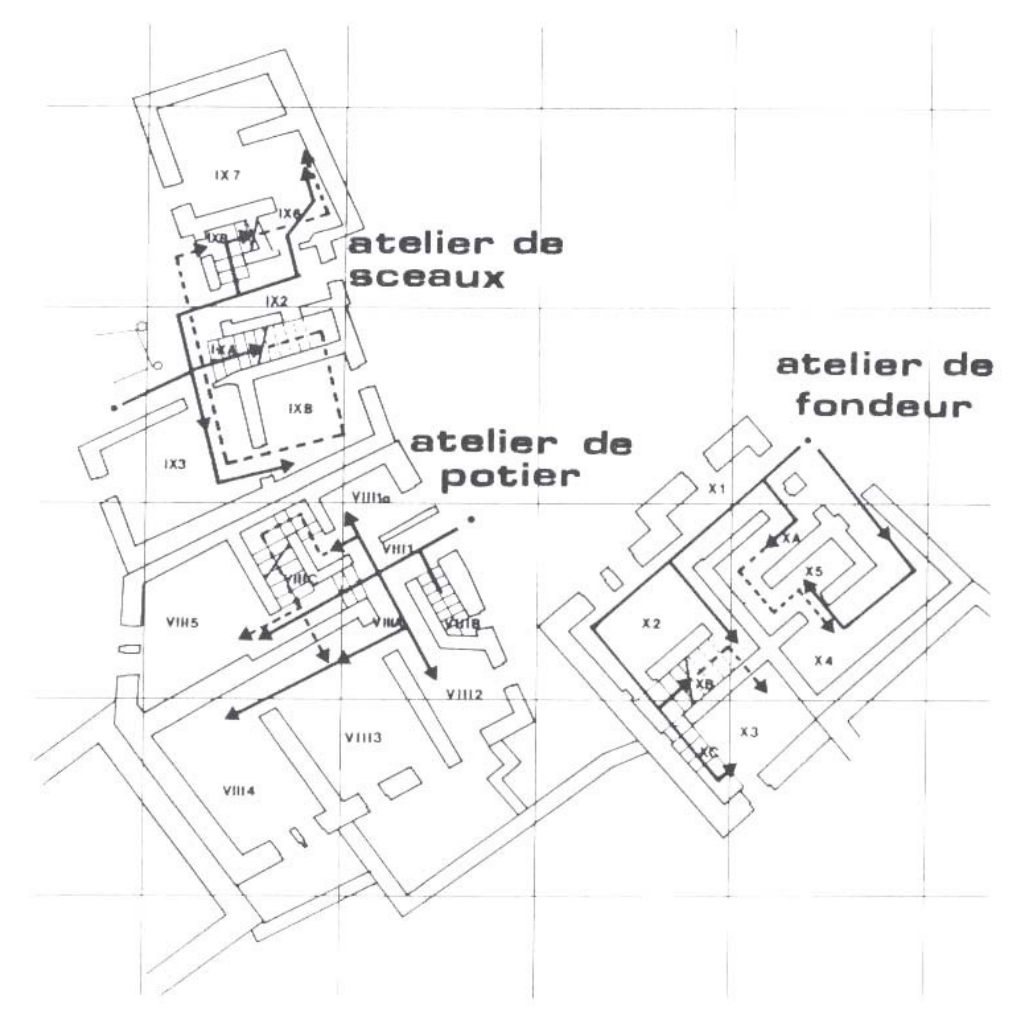

Fig. 93: Planta de reconstituição das oficinas da quadra Mu (Poursat, 1996, fig.53).

A mesma interpretação é sugerida por Schmid para as oficinas de fundição, selos e ao sul. Na oficina de fundição a escadaria tipo $\mathbf{U}$ estaria na peça X 5, da mesma maneira do oficina de cerâmica, a escadaria ligaria do subsolo, o piso térreo e seguindo ao segundo 
pavimento com terraço. Contudo, a peça X 5 não encontra-se também a parede divisória que suportaria a escadaria e as paredes da oficina são menos espessas que a de cerâmica, 0,30 m, com exceção da parede externa, se encontra ao lado com o edifício $\mathrm{E}$, que não significa que seja de sustentação. A área total do edifício é de $35 \mathrm{~m} 2$, que significa uma construção muito pequena para suportar um segundo quanto mais um terceiro pavimento. Além dessa escadaria, ele sugere uma escadaria secundária tipo $\mathbf{L}$, que conectaria o piso térreo ao subsolo, portanto ele coloca duas escadarias ligando o subsolo. Pela planta da construção no seu estado atual, não encontra-se nenhum vestígio e nem indícios de pisos superiores ou inferiores. Já para a oficina sul, de 70,00 m2, é mais complicado ainda seguir o raciocínio do arquiteto, porque é praticamente impossível analisar essa construção que se encontra em péssima conservação e não possui também o restante dela. Quanto mais sugerir, como Schmid alega, um edifício de dois andares, e duas escadarias distintas para o seu acesso. Uma tipo $\mathbf{U}$ e a outra, parelela, tipo L. E na oficina de selos, área total de $56,00 \mathrm{~m} 2$, a sugestão do arquiteto é de duas escadarias paralelas, uma ao norte (peça IX 6) e a outra ao sul (peça IX 5), da peça IX 2, uma levaria ao piso superior, enquanto a outra também levaria ao piso superor e se estenderia para o terraço. Essa escadarias são do tipo I e L. As espessuras das paredes são no máximo de $0,40 \mathrm{~m}$ de espessura e as paredes divisórias da área IX 2, são de $0,30 \mathrm{~m}$. Da mesma maneira, não seria possível suportar um segundo pavimento, nem um terceiro. Todas as metragens quadradas das áreas de todas oficinas não mostram estruturas para obter escadarias. São espaços pequenos e com acesso mais simples. Outra elemento são as paredes, elas são diferentes do restante dos edifícios analisados no catálogo. E a última observação em relação as escadarias sugeridas são excepcionais para toda a cidade de Mália, em forma de espirais. Ela só existe uma no palácio de Cnossos, na área residencial, a grande escadaria da quadra nobre.

Para a maioria das sugestões do arquiteto Schmid para as oficinas da quadra Mu é 
do tipo $\mathbf{U}$, mas ele também sugere as do tipo $\mathbf{L}$ e I. Para a oficina de selos a sugestão é de escadas tipo I, possuindo quatro andares incluindo o terraço e subsolo. Entretanto, assim como as outras, ela também não possui evidências ou vestígios para os vãos de escadaria e seus pavimentos superiores. 
Verificaremos agora o acesso das escadarias, sua situação e localização dentro das construções, tanto nas residências, como no palácio. A análise será em relação às entradas e saídas dos edifícios e não às quadras, portanto, no ponto de vista de um usuário externo. No entanto, o pátio central do palácio é uma área pública, e será analisada a partir do pátio central.

Separamos em três situações quanto à localização e ao acesso: a primeira é uma localização clara, de acesso imediato e visibilidade fácil. Na maioria das vezes elas estão próximas à entrada dos conjuntos; a segunda, localizada no interior do conjunto, portanto, central; e a terceira, são as mais restritas, de acesso controlado e não imediato.

Na primeira situação temos as casas: Delta Beta bloco leste (1), Delta Alfa (1), Épsilon (1- entrada secundária), Zeta Alfa (1), Zeta Beta (1), Cripta Hipostila (1) e as escadarias do palácio: I, Monumental, Grande escadaria, e IX. Em um total de 10 escadarias. Entretanto, duas escadarias dessa situação também são consideradas restritas pelo fato de possuírem portas, são: Zeta Alfa e a Grande escadaria do palácio.

Para a segunda situação: Delta Beta bloco oeste (1), Épsilon (1), Casa Mu A (3) e Casa Mu B (2) e para o palácio: XIX e XXII. Totalizando 7 escadarias residenciais e 2 no palácio.

Na terceira e última situação: Épsilon (1), Zeta Beta (1), Casa Mu A (1), Delta Beta bloco central (1), Cripta Hipostila (2) e para o palácio: II, IV, XIII, XVII, XXI e XXVII. São 4 escadarias restritas nas residências e sete nos edfícios públicos. Totalizando 12 escadarias.

Portanto as que mais predominam são as restritas e as de acesso fácil, e a segunda situação, com 9 escadarias, não é muito usada. Contudo, assim como as formas, é dificil estabelecer os critérios funcionais que determinam o emprego destes tipos de escadariasnas 
residencias. No entanto o que se percebe no palácio é o acesso controlado como padrão mais comum, portanto o segundo patamar e mais importante e não acessível ao público em geral. E onde se concentra um maior número de escadarias são nas áreas cerimoniais e de aparato, as quadras IV, VI, IX, XVI, XXI e XXII. Se tomarmos como parâmetro o padrão palacial, então as residencias teriam escadarias restritas em áreas lligadas a atividades também restritas, nas quais podem se inserir o aspecto de privacidade.

Apesar das escadarias já serem um fator fronteiriço, temos também as portas que faziam delas uma maior barreira. São na maioria escadarias nos edifícios públicos, nas quadras II, IV, e a Grande escadaria do palácio, a escadaria de entrada e escadaria 3 na Cripta Hipostila, e somente uma nas residências, na Delta Alfa. Quanto a essa questão, nos apoiamos nos valores e convenções comportamentais discutidas pelo pesquisador Donald Sanders, usando ferramentas de controle e uso em forma de sinais não verbais necessários para manter determinados comportamentos. Sanders comenta que os marcadores dos territórios regulam comportamentos específicos, quanto mais público o território é, mais a necessidade de sinais. E quanto mais privado, maior a convenção comportamental usada. Assim, é adicionado mais um elemento que determina o espaço público e privado na arquitetura minóica (SANDERS, $1990, .43-72)$.

Quanto às funções dos andares superiores, possuimos algumas sugestões. Esses andares estariam ligados às mesmas funções dos pavimentos térreos (GRAHAM ,1962; EFFENTERRE, 1980; SHAW, 1973) mas isso é relacionado aos palácios. Acredita-se que as salas cerimoniais, mais amplas e importantes, ficavam nos pavimentos superiores, seriam as salas para culto religioso e de reuniões, assim como a sala de banquete (GRAHAM, 1962, p.114-129) além da área residencial para os governantes. Quanto às interpretações das construções residenciais, as funções para o pavimento superior são mais limitadas ainda. $\mathrm{O}$ 
que podemos sugerir são ligações a espaços privados que necessitam esse tipo de barreira ou como Hallager sugeriu: lugares cobertos com espaços abertos que poderiam acomodar qualquer tipo de atividade (1990, p. 289-292). Quanto ao seu uso e sua circulação não possuímos nenhum indício direto para fazer tal interpretação.

Ainda seguindo nesta discussão sobre acessos e pavimentos superiores, existe um estudo elaborado de uma maquete do palácio de Mália que não foi publicado, mas está exposto na entrada de visitação do sítio. Podemos verificar outros acessos do palácio sugerido pelo arquiteto Schmid. Essa maquete foi elaborada em 1996, a pedido da Escola Francesa em comemoração aos 150 anos.

A reconstituição é mais da fachada e dos andares em vários blocos. Quanto a fachada, é fácil de identificar seus acessos visíveis, mas internamente não possuímos nenhum dado sobre a circulação, tanto vertical como horizontal. Pela maquete, a fachada oeste possui duas entradas, uma por uma escadaria na quadra I, tipo I, apoiada no bastião A e talvez nas peças I 2 e I 3. Essa escadaria é monumental e conectaria diretamente ao segundo pavimento do palácio. Acima do vão pode-se ver o terceiro pavimento, entretanto, não dá para entender sua conexão entre o segundo e terceiro andar. Nesse bloco, há quatro pavimentos, sendo o último um terraço coberto, mas também não se sabe como foi feita a ligação. A segunda entrada situa-se ao norte dessa mesma fachada, onde foi instalada uma porta para um pátio do setor noroeste e do pátio a entrada se daria também por uma escadaria tipo I, mais estreita do que a primeira e que se parece com uma escadaria externa, mas coberta. A escadaria se conectaria a um primeiro patamar, de acesso ao térreo, seguindo para o segundo patamar de acesso ao piso superior, se apoiando no bastião B. Da mesma forma da primeira escadaria pode-se ver o terceiro pavimento, há um terraço, mas sem a conexão dessa escadaria. Esse bloco não possui o quarto pavimento. 


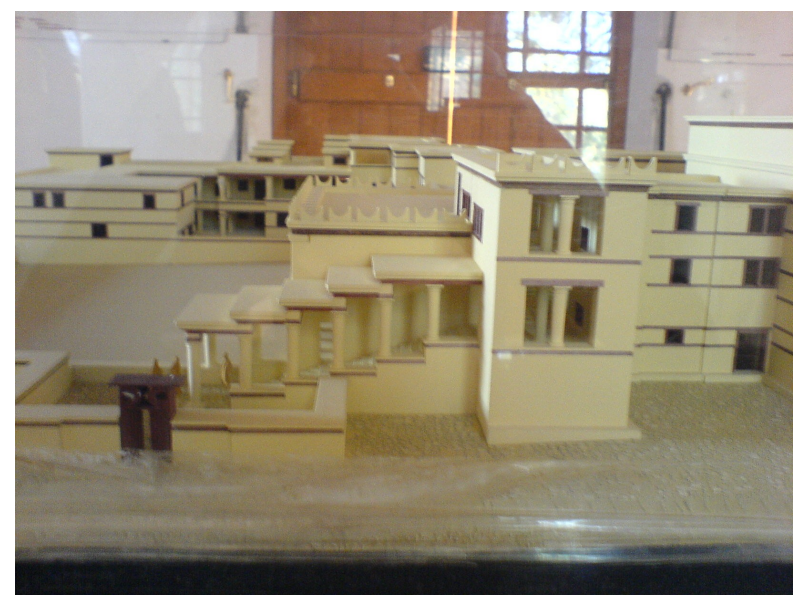

Fig. 94: Fachada oeste, escadaria quadra III (MAQUETE, 1996).

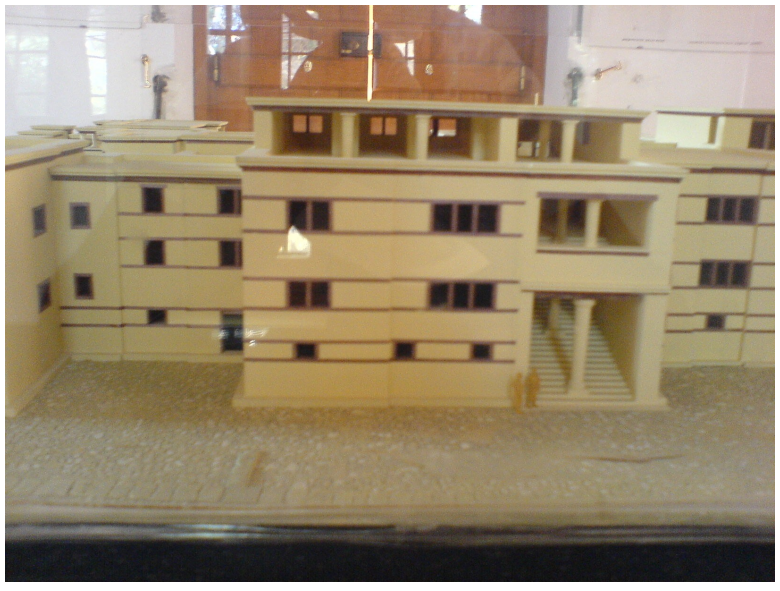

Fig. 95: Fachada oeste, escadaria quadra I (MAQUETE, 1996). 
$\mathrm{Na}$ fachada sul existem três entradas. Uma conectaria à quadra XVII pelo térreo, a outra para o pátio central e a terceira é através de uma escadaria de proporções monumentais. Seu acesso é pela fachada leste, contudo ela se estende ao longo da fachada sul. Ela também se apóia no bastião G da quadra XIV, ligando diretamente ao segundo pavimento, tipo I. Nesse bloco, as quadras XIII e XIV não possuem um terceiro andar.

$\mathrm{Na}$ fachada leste, encontram-se quatro entradas para o palácio. A primeira é a

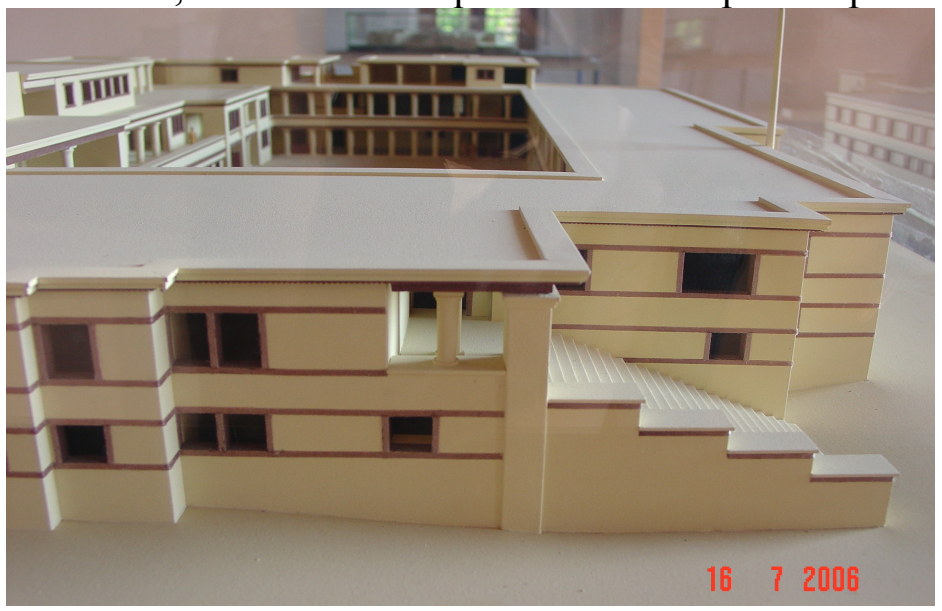

Fig. 96: Fachada sul, escadaria quadra XIV (MAQUETE, 1996).

entrada sudoeste para o pátio central, a segunda, por um pequena escadaria externa e coberta, tipo L, paralela à quadra de depósito, XI, conectando ao segundo pavimento. A terceira, outra escadaria, tipo I, paralela à quadra XXVI, ligando também ao segundo pavimento e a quarta na entrada noroeste para o pátio norte.

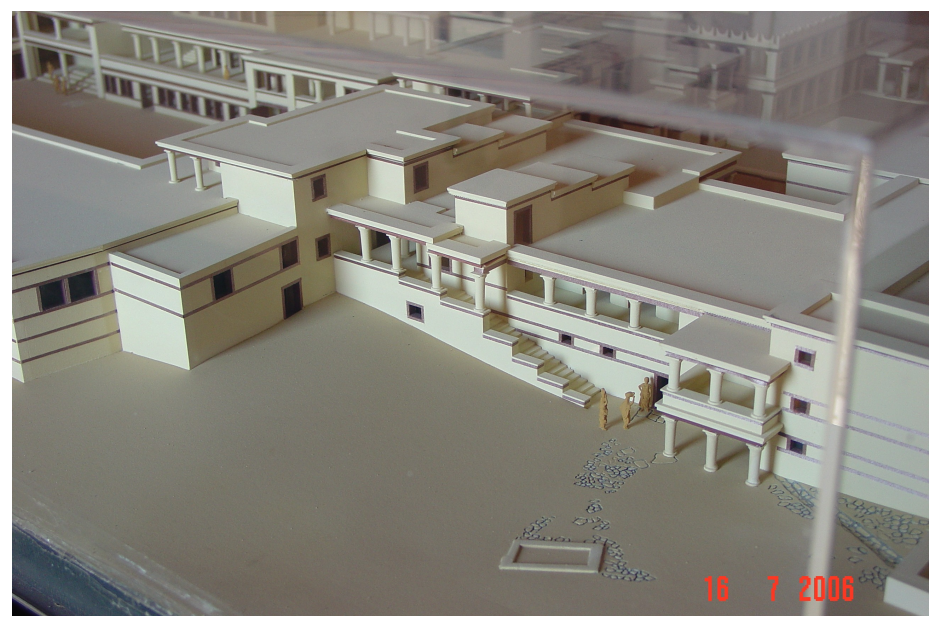

Fig. 97: Fachada leste, escadaria quadra XXVI (MAQUETE, 1996). 
$\mathrm{Na}$ fachada norte existe somente uma entrada ligando também ao pátio norte, o restante seria murado contornando um grande pátio que chegaria até a porta de entrada da fachada sul.

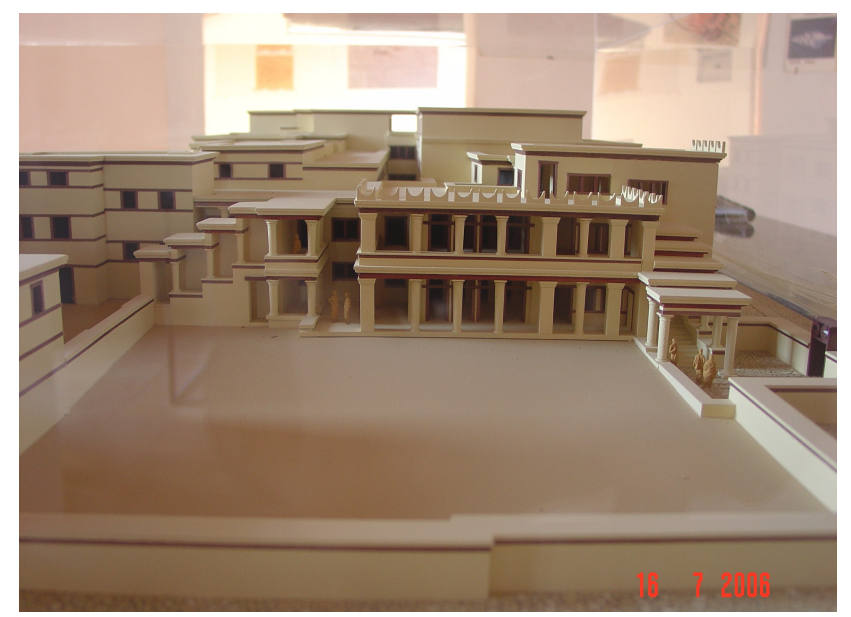

Fig. 98: Fachada norte, escadaria do pátio norte

No pátio central, temos a visibilidade da fachada interna oeste com a grande escadaria com portas e a escadaria monumental. No segundo pavimento, existe um corredor aberto para o pátio central onde é possível ver uma escadaria interna que ligaria o segundo ao terceiro pavimento, tipo I, apoiada no vão da peça VII 10.

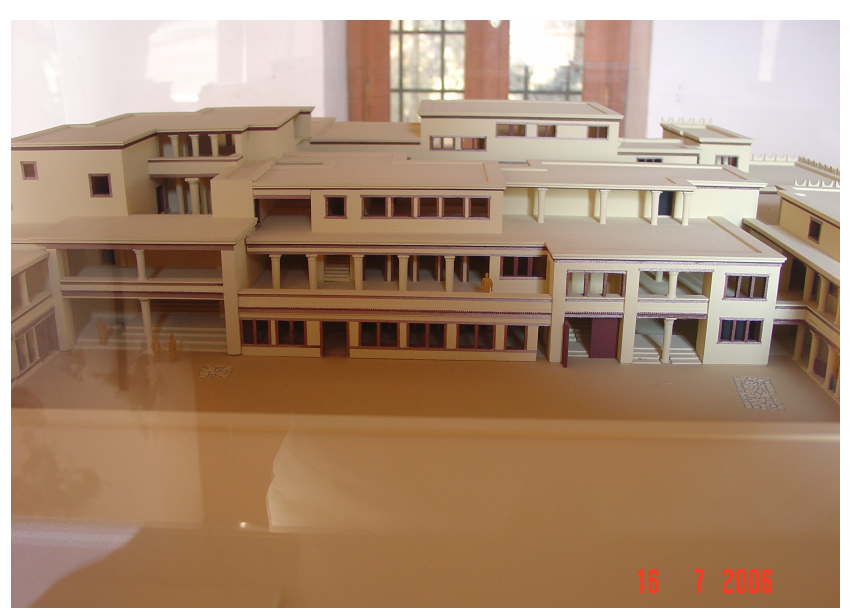

Fig. 99: Fachada pátio central, escadarias: Monumental e

Em entrevista, o arquiteto Schmid afirma que exagera, sim, na quantidade de 
escadarias no palácio, além de concordar com as escadarias que foram catalogadas por essa pesquisa. Segundo Schmid, o número é proporcional ao que ele interpreta das escadarias na quadra $\mathrm{Mu}$, assim como sugere para as escadarias nas oficinas. É difícil aceitar essa quantidade de escadarias externas ligando diretamente ao segundo pavimento, porque pela análise das escadarias internas desta pesquisa, elas estão em situações restritas, enquanto para Schmid os acessos pelas escadarias mostram passagens visíveis, diretas e acessíveis ao segundo pavimento sem barreiras para circulação do público em geral, o que contraria o padrão observado no palácio, que mostra predôminancia de escadarias restritas. Isso está também em conflito com os princípios até agora observados na arquitetura palacial minóica, que tem o acesso ao segundo pavimento apenas pelo pátio central, nas fachadas internas e por escadarias internas. Esses tipos de escadarias da fachada externa não são encontrados em nenhum dos grandes palácios, de Cnossos e de Festos. Devemos lembrar que o palácio possui lugares públicos, mas na sua grande maioria são espaços semi-públicos, o acesso não era para todos.

Quanto ao material de construção, constatamos que das 31 escadarias analisadas no catálogo a predominância do uso de madeira é maior pela falta de evidência dos degraus. Já no palácio, são seis escadarias que possuímos, cujos primeiros degraus são em blocos de ammouda e possivelmente o restante em madeira, e cinco com todos os degraus em madeira (escadarias leves). Para a Cripta Hipostila, todas são de blocos de calcário e estucadas. E nas residências, são em madeira, exceto três escadarias na Casa $\mathrm{Mu} A$, e uma na Casa $\mathrm{Mu} \mathrm{B}$, todas elas estucadas. 


\begin{tabular}{|c|c|c|c|c|}
\hline Edifícios Privados & $\begin{array}{c}\text { Comprimento } 1^{o} \\
\text { lance }(m)\end{array}$ & $\begin{array}{c}\text { Comprimento } 2^{o} \\
\text { lance }(m)\end{array}$ & $\begin{array}{c}\text { Largura } \\
\text { (m) }\end{array}$ & Tipo \\
\hline Zeta Alfa & 3,90 & 3,00 & 1,00 & $\mathrm{~L}$ \\
\hline
\end{tabular}




\begin{tabular}{|c|c|c|c|c|}
\hline Edificios Privados & $\begin{array}{c}\text { Comprimento } 1^{o} \\
\text { lance }(\mathrm{m})\end{array}$ & $\begin{array}{c}\text { Comprimento } 2^{o} \\
\text { lance }(\mathrm{m})\end{array}$ & $\begin{array}{l}\text { Largura } \\
\quad(m)\end{array}$ & Tipo \\
\hline \multirow[t]{2}{*}{ Zeta Beta } & 4,50 & 3,20 & 1,00 & $\mathrm{~L}$ \\
\hline & XII & & 1,00 & I \\
\hline Delta Beta - leste & 5,50 & & 1,20 & I \\
\hline $\begin{array}{l}\text { Delta Beta - } \\
\text { central }\end{array}$ & 5,50 & & 1,00 & I \\
\hline Delta Beta - oeste & 4,0 & 4,0 & 1,00 & $\mathrm{~L}$ \\
\hline Delta Alfa & 2,70 & 2,70 & 1,00 & $\mathrm{U}$ \\
\hline \multirow[t]{3}{*}{ Épsilon } & 4,00 & 4,00 & $1,00 / 1,20$ & $\mathrm{U}$ \\
\hline & 11 e $12 \quad 5,00$ & 5,00 & 1,00 & $\mathrm{U}$ \\
\hline & $20 \quad 5,00$ & & 1,00 & I \\
\hline \multirow[t]{4}{*}{ Casa A } & 3,00 & 3,00 & 1,00 & $\mathrm{U}$ \\
\hline & 2,20 & 1,00 & 1,00 & $\mathrm{~L}$ \\
\hline & 4,00 & & 1,00 & I \\
\hline & III C & & 0,80 & I \\
\hline \multirow[t]{2}{*}{ Casa B } & IV A & & 0,80 & I \\
\hline & IV B & & 1,00 & I \\
\hline Edifícios Públicos & $\begin{array}{c}\text { Comprimento } 1^{o} \\
\text { lance }(m)\end{array}$ & \begin{tabular}{|c|}
$\begin{array}{c}\text { Comprimento } 2^{o} \\
\text { lance }(m)\end{array}$ \\
\end{tabular} & $\begin{array}{c}\text { Largura } \\
\text { (m) }\end{array}$ & Tipo \\
\hline \multirow[t]{3}{*}{ Cripta Hipostila } & $1 \quad 3,70$ & 0,80 & 1,50 & $\mathrm{~L}$ \\
\hline & 2,00 & Até 5,00 & 0,85 & $\mathrm{U}$ \\
\hline & 2,80 & 3,00 & 1,20 & $\mathrm{U}$ \\
\hline \multicolumn{5}{|l|}{ Palácio } \\
\hline I & 3,50 & 3,70 & 2,00 & $\mathrm{U}$ \\
\hline II & 4,50 & 5,00 & $1,50 / 1,80$ & $\mathrm{U}$ \\
\hline IV & 4,50 & 5,00 & 1,70 & $\mathrm{U}$ \\
\hline VI - Grande esc. & 8,00 & & 3,20 & I \\
\hline IX & 9,40 & 9,05 & 2,00 & $\mathrm{U}$ \\
\hline XIII & 5,50 & 4,00 & 1,00 & $\mathrm{U}$ \\
\hline XVII & 4,00 & & 1,40 & I \\
\hline Monumental & & & & I \\
\hline XIX & 4,50 & & 2,00 & I \\
\hline XXI & 9,00 & 11,50 & 1,50 & $\mathrm{U}$ \\
\hline XXII & 10,50 & 12,00 & 2,00 & $\mathrm{U}$ \\
\hline XXVII & 4,00 & 4,00 & 1,00 & $\mathrm{U}$ \\
\hline
\end{tabular}


Para as escadarias residenciais, as larguras são semelhantes, por volta de 1,00 m, contudo, os comprimentos dos vãos que elas ocupam variam. As menores, que se localizam na quadra $\mathrm{Mu}$, são de no mínimo de 2,00 $\mathrm{m}$ e chegam até 5,00 $\mathrm{m}$ para as escadarias tipo $\mathbf{U}$ e L. Para as tipo I são de no mínimo 4,00 m até 5,50 $\mathrm{m}$ de comprimento. Para as escadarias tipo I de 4,00 m de comprimento teria por volta de 15 degraus, sua inclinação seria maior e romperia uma altura de piso a piso de no mínimo $2,50 \mathrm{~m}$. As de $5,00 \mathrm{~m}$ seriam mais confortáveis, porque poderiam possuir maior profundidade para cada degrau, por volta de 0,30/,032 m, terim mais degraus, 17, e uma inclinação menor. Romperiam uma altura de por volta 2,85 m. Com exceção da escadaria da Casa Mu B, IV a, que possui 2,00 m de comprimento e rompe somente $1,90 \mathrm{~m}$ de altura. Essa foi a menor altura de piso a piso que possuímos em todas as escadarias catalogadas.

Portanto, existiu uma preferência de materiais mais pesados e mais resistentes em edifícios públicos do que nos privados. Seria talvez pelo fato de que essas escadarias possuíssem um maior número de circulação (resistência do material), maiores dimensões (apoio para o restante das escadarias) e função estética. Já para os casos subterrâneos estariam apoiadas diretamente no solo (caso da Cripta Hipostila e Casa Mu B).

Outro fator que levantaremos na análise geral são as dimensões usadas nas escadarias. Devido a um grande número terem usados materiais leves, madeiras, iremos nos basear somente nos vãos que as escadarias se localizaram. Eles já nos dão pistas do número de degraus que poderiam possuir, além de sua inclinação e as alturas de piso a piso.

No que se refere às escadarias tipo $\mathbf{U}$ e $\mathbf{L}$ teriam mais conforto porque possuiriam um patamar intermediário e teriam mais degraus, ropendo de 3,00 a 3,50 m de piso a piso. Os 
espaços menores, que se localizam na quadra $\mathrm{Mu}$, elas romperiam uma altura menor, de por volta de 2,00 a 2,50 m e sua inclinação seria maior, assim como as alturas dos degraus.

Nos espaços públicos, elas, na grande maioria são excepcionalmente confortáveis. Baseando-se nas hipóteses levantadas por Graham (1962) e Van Effenterre (1980) para o palácio, as alturas variam para as maiores escadarias, e maiores vãos, de 4,50 a 5,00 m de piso a piso, nas quadras IX, XXI e XXII. Contudo, a altura não varia nos blocos onde elas estão inseridas, e nesse caso os vãos menores exigiriam uma altura maior e menor profundidade para cada degrau, gerando assim maiores inclinações para as escadas. Seria o caso do bloco oeste, que possui as escadas da quadra I, A Grande escadaria, e a Escadaria Monumental, além da escadaria da quadra II, de menor vão, com maior inclinação para romper tal altura. Para o bloco residencial, o vão IV romperia uma altura menor, por volta de 3,50 a 4,00 m. Para o bloco sudoeste, a quadra XVII romperia uma altura de 3,00 a 3,50 m, da mesma maneira para os blocos XXVII e XIII.

Saindo do palácio, percebemos que no corpo principal do edifício da Cripta Hipostila a altura de piso a piso seria de no mínimo 2,10 a 2,50 $\mathrm{m}^{20}$, baseando-se na escadaria 1, da entrada principal. A segunda escadaria seria mais restrita poque ela é mais inclinada e deveria romper uma altura maior do que a primeira escadaria. Já a terceira seria de fácil acesso, para transportar possivelmente vasos de armazenamento e romper uma altura menor do que a segunda, pois seguiria para o mesmo nível superior da escadaria 2.

Podemos supor as alturas do pavimento térreo para o segundo pavimento superior, e devido os materiais de construção e os abalos sísmicos que essa região sofre, provavelmente os pavimentos seguintes teriam uma altura menor, mas não deixando de ser confortáveis como o que possuímos atualmente, 2,50 a 2,85 m de altura.

20 - Existe na parede sul do corpo principal o negativo dos vigamentos do piso superior (SHAW, 1973, p. 155). 


\section{SÍNTESE}

Com os dados adquiridos no catálogo, podemos verificar a presença de barreiras que comumente aparecem na arquitetura minóica. Percebemos também como os construtores já tinham a habilidade de edificação visando pavimentos superiores, o uso de suportes e apoios, e a definição de uma circulação vertical interna. As construções na sua maioria eram elevadas, seguiam esse padrão, tanto para edifícios que faz essa ligação de uma maneira simples e comum comparada aos dias atuais, como também para os mais complexos, por exemplo, as residências Zeta Beta, Casa Mu A e Épsilon, que mostram como os construtores minóicos possuíam a habilidade de elaborar e erguer construções complexas e labirínticas, assim como os acessos restritos que aparecem nas residências, na Cripta Hipostila e em algumas quadras do palácio. Um jogo de patamares e pavimentos, com uma circulação bastante emaranhada para uma época distante. A sugestão da entrada do bloco central, na residência Zeta Beta, que seria por uma escadaria, difere de todos as construções da arquitetura minóica, mas segue a opinião de Graham e Palyvou de que os pavimentos superiores são de grande importâcia e esse não pode se disassociar das características da arquitetura minóica e sua indentidade ${ }^{21}$.

Observamos também que outros sítios da ilha, Cnossos e Festos, possuem uma topografia desnivelada que proporciona tal artimanha, o jogo de pavimentos. Podemos supor que o sítio de Mália apresentaria um urbanismo mais simples que os sítios de Cnossos e Festos, se considerarmos apenas seu nível térreo, já que não dispomos de seus pavimentos superiores. Mas essa falsa percepção pode ser superada ao se analisar seus blocos verticias e

21 - Como foi mencionado no começo, infelizmente só possuímos, na grande maioria dos edifícios da Creta minóica, os pavimentos térreos que já nos ajudam a pesquisar sobre essa civilização através desse mega artefato. Contudo, ainda restam algumas das partes que seriam fundamentais para adquirir mais conhecimento, que são os pavimentos superiores. 
sua tridimensionalidade. Forma-se então um skyline muito interessante e muito perspicaz. Além da paisagem e visualização, não podemos deixar de comentar as vias que separam os edifícios uns dos outros. A malha urbana das cidades minóicas foram planejadas para pessoas e animais. Para nós, elas se parecem mais com calçadas, e isso torna a cidade mais vertical ainda. Voltamos então ao espaço interno, onde os pavimentos superiores dariam mais espaços em comparação ao exterior. Se o que ofereciam era menor, por que não obter isso internamente?

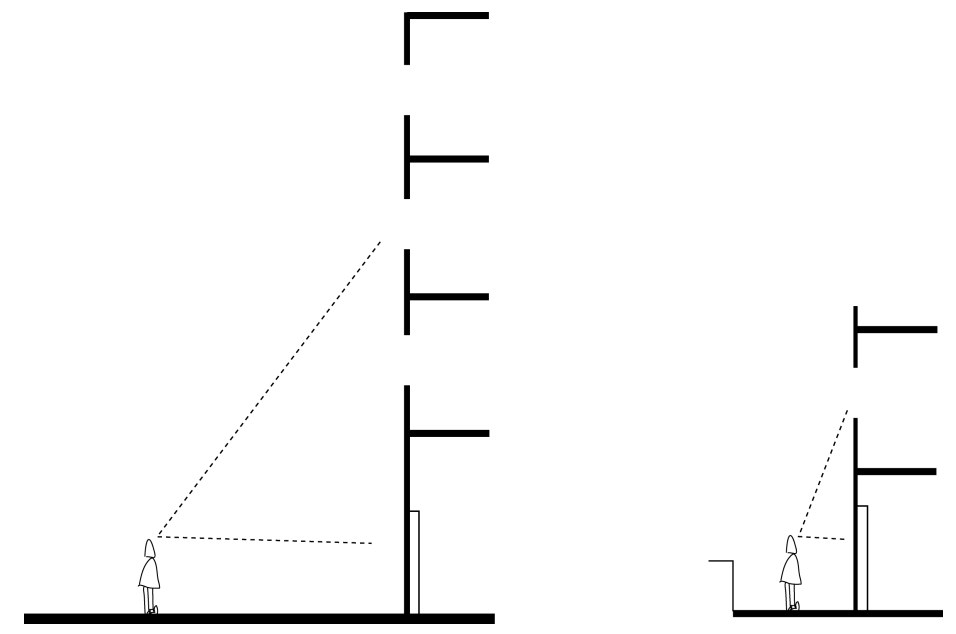

Fig. 100: Cortes esquemáticos: fachada do palácio, à esquerda; fachada residencial, à direita.

A pesquisa visa estabelecer padrões e regularidades das escadarias em vários aspectos, como foi apresentado nesta análise, assim como, a questão do seu uso e função. Mas o mais interessante do levantamento da pesquisa é o fato de que a maioria das construções possuiam escadarias, e essa regularidade já estabelece um padrão no conjunto de elementos que caracteriza a arquitetura minóica e nos leva a questionar o por quê dessa verticalização para os minóicos. Como já foi comentado, os pesquisadores Van Effenterre (1980, p.180) e Allegrette $(1991,28)^{22}$ acreditam que a elevação da cidade maliota nessa direção foi por causa 
da falta de espaço. No entanto, em uma das maiores e mais antigas quadras que o sítio de Mália possui, a quadra Mu, não foi reaproveitado o espaço para tal expansão já que o período de utilização termina no final do protopalacial. Esse é um dos pontos mais importantes para a pesquisa. O seu uso não dependeu da questão física, demográfica ou topográfica, mas sim cultural. Essa característica remete também à cronologia do seu uso. As escadarias, sem dúvida alguma, já tinham lugar em épocas anteriores ao/do protopalacial. Portanto, partiu primeiramente das residências e depois para os edifícios grandes, como o palácio.

Uma outra questão que surge a partir dessa conclusão é: a que fatores culturais estaria vinculada? Ao econômico, ao político, ao religioso, ao tecnológico ou ao social? O social já está de uma certa maneira subvinculado a todos os outros fatores. Quanto ao político e ao econômico, é difícil estabelecer esse vínculo, porque se o elemento vertical foi usado em épocas anteriores e em residências, ele também estaria ligado à arquitetura vernacular dos minóicos. O que nos resta é inicialmente o religioso e o técnológico, e posteriormente o social em um uso comum e não restrito somente para alguns usuários.

Essa transformação de fatores culturais relacionada ao papel de uma escadaria está inicialmente conotada na função primária, a de conexão. Nessa pesquisa a interpretação do elemento vertical direciona-se não apenas a função, e sim a concepção do habitar, do usar, e descobrir a denotação - sua função secundária; reconhecer as direções de habilidade que sugere e que orienta como complexo de estímulos. Para o pesquisador Eco, no curso da história, as funções primárias e secundárias são passíveis de perda, recuparações e substituições de vários tipos, contudo, é mais evidente no campo das formas arquitetônicas, onde a opnião comum crê lidar com objetos funcionais portadores de indicações inequivocáveis (ECO, 2003, p.208).

No contexto histórico dessa transformação verificamos que a prática do culto 
religioso data do pré-palacial. O culto foi uma continuação dos rituais funerários que já existiam (PEATFIELD, 1987, p.93). As cavernas foram, inicialmente, usadas como sítios de habitação no período neolítico. O uso das cavernas como lugares de culto religioso aparecem primeiramente no início do período protopalacial. As cavernas que fornecem uma rica variedade de objetos votivos são: a caverna Camares, que se localiza na encosta do Monte Ida, 6000 metros acima do nível do mar; a gruta de Dite ou caverna de Psychro, localizada a oeste da planície de Lasithi, no Monte Dite; a caverna da Ida, situada a oeste do planalto Neda, no Monte Ida. Todas foram vistas como um fenômeno do período palacial em Creta (LEUVEN, 1981, p.13).

É encontrado na ilha de Creta Minóica um outro tipo de espaço sagrado, os Santuários de Pico (Peak Sanctuaries) que são locais de cultos situados no alto de montanhas da ilha. Seu surgimento, no período protopalacial, (assim como o das cavernas), foi um desenvolvimento dos espaços cultuais vinculados às tumbas do período do Minóico Antigo como lugares de continuidade do culto. Sua proliferação na ilha foi uma manifestação da religião da população rural, que se expandiu para os centros urbanos (PEATFIELD, 1987, p.93). Os objetos encontrados nos santuários de pico são semelhantes aos dos palácios (mesas de oferendas, inscrições em Linear A e a fina cerâmica Camares, entre outros).

Contudo, houve um rompimento dos locais do uso de culto durante o protopalacial, uma transferência dos espaços naturais para os construídos, o único que permanece em uso até o fim da Era Palacial foi o santuário do monte Juktas (KARETSOU, 1981, p.145). E dessa maneira, uma extraordinária evolução social e política tomou lugar no começo do período protopalacial e é muito provável que isso tenha tido influência na religião (BRANIGAN, 1970, p. 93). O surgimento de núcleos urbanos e as construções de palácios nas cidades são vistos como alguns dos fatores mais significativos da civilização minóica, já 
que os palácios são reconhecidos hoje como sendo edifícios erguidos para servir todos os aspectos centrais desta civilização. Uma enorme variedade de evidências de rituais religiosos foi encontrada dentro destes centros. Algumas das características mais significativas de culto religioso e que fizeram também parte dos adornos arquitetônicos palaciais foram os cornos de consagração e os machados duplos. Estas duas evidências que caracterizam essa cultura fizeram com que o arqueólogo Sir Arthur J. Evans denominasse como "minóica", em referência ao lendário rei Minos, o mais famoso monarca desta civilização e responsável pela construção do labirinto do Minotauro.

Nessa complexa cultura sabemos que não existia um único tipo de culto, mas vários. O culto religioso foi praticado dentro do espaço palacial, nas cidades (santuários urbanos), no espaço natural (cavernas e santuários de pico), como também nas residências.

Analisando através desse contexto histórico as paisagens são freqüentemente uma materialização da memória, fixando histórias individuais ou sócias dentro de espaços. Pesquisas da ciência cognitiva sugerem que a memória humana constrói antes mesmo de recuperar, e que o passado, desse modo, origina-se da elaboração da memória cultural, o qual é auto-constituído socialmente (KNAPP, ASHMORE, 1999, p.13). A memória acentua a continuidade na paisagem, freqüentemente através da reutilização, re-interpretação ou restauração e reconstrução. Pessoas reconhecem, gravam e coletivamente mantêm certos lugares em termos de rituais, simbólicos ou cerimoniais, inversamente, esses lugares criam e expressam identidade cultural.

Dentro desse conceito que apontamos, a necessidade de verticalização e o uso do elemento que faz essa ligação, as escadarias, atribuídas a um fator cultural, do religioso para o 
social, que dessa maneira, acabaram se fixando no uso e organização do espaço da arquitetura minóica,. As atividades de culto em lugares naturais teve seus princípios que regeram a organização dos espaços contruídos, e assim produziram nos fatores antagônicos como o sagrado e o profano, oculto e visível, dentro e fora, restrito e aberto, público e privado. Apesar da cidade de Mália não ter se expandido horizontalmente, houve o aproveitamento do espaço usando pavimentos superiores, mas o planejamento construtivo ocorreu devido a introdução de esquemas cognitivos da cultura minóicas. O espaço é um meio do qual podemos analisar algumas características: pequeno ou grande, próximo ou longe, alto ou baixo, todas elas condições físicas nas quais vivemos (RENFREW, 2000 p.399). Não são somente os elementos físicos que atuam nos mapas mentais, os simbolismos, os significados, os aspectos sócio-culturais, o contexto, a congruência entre forma e atividade, a segurança etc, já que a construção de mapas cognitivos incorpora uma ampla variedade de estímulos (RAPOPORT, 1978 p.127).

As conotações "simbólicas” na arquitetura minóica estão vinculadas aos recursos anteriormente usados, segurança (grutas), proteção (divindades), purificação (sala lustrais, água), reuniões/convívio (criptas), privacidade (interiorização), elevação (espiritualização); essas são as funções secundárias. Porém, houve uma oscilação, no tempo, e no espaço, do objeto de uso, uma defasagem entre a função primária e a secundária. Permanece a função primária e perde-se as funções secundárias: isso é o princípio do mapa coginitivo.

Essa análise mostra uma possibilidade de interpretação da introdução das escadarias nas construções minóicas, contudo, não podemos afirmar que os mapas mentais existem sempre, mas, claramente, que atuamos através de um tipo de esquema cognitivo (RAPOPORT, 1978, p. 126). 
Finalizando esta análise geral que se iniciou com os aspectos físicos, técnicos, articulações, fronteiriços e configurativos dos dados levantados no catálogo das escadarias em seu semblante global da arquitetura minóica para descobrir padrões e regularidades, assim como a reavaliação das interpretações de reconstituições produzida anteriormente à essa pesquisa, resultando na analise de sua evolução, suas funções primárias e principalmente tentar descobrir o princípio da escolha das escadarias na concepção do espaço construído e no planejamento que esta imbutido no esquema cognitivo da cultura minóica, os valor psicossociais. 


\section{CONCLUSÃO}

Em conclusão à pesquisa dessa dissertação, o elemento arquitetônico analisado exigiu o transcorrer de vários aspectos, desde o processamento dos vestígios da construção minóica até os elementos mais importantes: a concepção, a percepção e o princípio dos usuários.

Mais específicamente, a pesquisa abrangeu o contexto da arquitetura minóica geral (características físicas e dinâmica das suas transformações), o lenvantamento do conjunto de elementos que identifica e caracteriza a escadaria, as diferenças e semelhanças das diversas construções apresentadas na cidade maliota, o levantamento de interpretações que existe na bibliografia disponível sobre o assunto, a definição e os critérios usados na construção das escadarias, e finalmente, o levantamento específico e pontual de cada uma das escadarias que sabemos atualmente que existiam, apresentando suas características e os edifícios que as abrigaram. Esse último, é o ponto mais importante da pesquisa, o corpo documental que nos orientou a interpretação, direcionando tanto para os padroes e regularidades que existem na arquitetura minóica como para as possiveís interpretações de funções das escadarias, seu papel no horizonte da cidade maliota, seu uso, sua organização, seus limites, seus aspectos de demarcação territorial e fronteiriço, e a concepção e percepção dos construtores e usuários desses edifícios.

Dentro do trabalho, a reavaliação de interpretações sobre as escadas de outros pesquisadores foi constante, base na qual nos apoiamos, concordando ou não e que foi de grande importancia para o objetivo dessa dissertação.

As conclusões que chegamos na análise geral, capítulo anterior, nos levou também a um aspecto polêmico que existe nos vários estudos arqueológicos, o religioso, pois 
como apontamos no capítulo anterior, a aparição de espaços cultuais e cerimoniais nos palácios, distribuídos nos pavimentos térreos e nos superiores principalmente no período neopalacial, sugere que poderia ter ocorrido uma transferencia de sentidos e funções abrangidas pelos santuários de pico e de cavernas para o edifício palacial, na medida em que a concentração desses espaços em áreas altas (pavimentos superiores) reproduziria a condição elevada vista nos santuários de pico, dominante sobre a paisagem humana das terras baixas cretenses, agora transposta para a paisagem urbana, na qual o palácio se coloca como a construção mais elevada e dominante do núcleo humano. No entanto essa discussão, aqui apenas assinalada, requer maior conhecimento sobre esse assunto, mais do que o breve histórico apresentado sobre os espaços usados no culto minóico, tanto dos naturais como do construídos, abrindo uma perspectiva de estudos que poderá ser explorada posteriormente. Mesmo assim a pesquisa nos mostrou que o elemento vertical, as escadarias, são certamente o centro de um sistema das estéticas da arquitetura cretense", como argumentou Rodenwaldt (citado por GRAHAM, 1962, p.180)23, ou melhor, não só da arquitetura como das cidades cretenses. E dessa maneira, elas podem ser vistas como “... as artérias e as veias para o corpo humano. São imprescindíveis para a comunicação e nesse sentido a escada seria como o coração de um edifício, enchendo-o de vida", declaração do arquiteto italiano Vicenzo Scamozzi ${ }^{24}$. 


\section{BIBLIOGRAFIA}

\section{$\underline{\text { Abreviaturas }}$}

\section{Periódicos}

AAL - Acta Archaeologica Lovaniensia

AEGAEUM - Annales d'Archéologie Égéenne de l'Université de Liège

AJA - American Journal of Archaeology

ARA - Annual Review of Anthropology

JSAH - Journal of the Society of Architectural Historians

OpAth - Opuscula Atheniensia

RA - Revue Archéologique

\section{$\underline{\text { Atas de Congressos e Simpósios, Obras Coletivas, Coletâneas }}$}

AEGAEUM 23 - DRIESSEN, Jan; SCHOEP, Ilse \& LAFFINEUR, Robert (Eds.) - Monuments of Minos, Rethinking the Minoan Palaces. Proceedings of the International Workshop “Crete of The Hundred Palaces?” Université Catholique de Louvain, Louvain-laNeuve, 2001.

FMP - HAGG, Robin \& MARINATOS, Nanno (Eds.) - The Functions of the Minoan Palaces. Proceedings of the Fourth International Symposium at the Swedish Institute in Athens 1984. Stockholm, Paul Astrom, 1987.

HEP - DARCQUE, Pascal \& TREUIL, René (Eds.) - L'Habitat Égéen Préhistorique. Actes de la Table Ronde du CNRS, Athènes, 1987. Paris, De Boccard, 1990 (BCH Suppl. XIX).

Le Système Palatial - LÈVY, E. (Ed.) - Le Système Palatial en Orient, en Grèce et à Rome. Actes du Colloque de Strasbourg 1985. London, E.J. Brill, 1987. 
Minoan Society - KRZYSKOWSKA, Olga \& NIXON, Lucia (Eds.) - Minoan Society. Proceedings of the Cambridge Colloquium 1981. Bristol, Bristol University Press, 1983.

Sanctuaries - HAGG, Robin \& MARINATOS, Nanno (Eds.) - Sanctuaries and Cults in the Aegean Bronze Age. Proceedings of the First International Symposium at the Swedish Institute in Athens 1980. Stockholm, Paul Astrom, 1981.

AllegretTe, A.H. - Organização Espacial no Palácio de Mália (1700 - 1450 a.C.. Dissertação (Mestrado) - FFLCH USP, São Paulo, 1991.

ALlEGRETte,A.H. - A Cripta Hipostila: Análise Espacial da Arquitetura Minóica do Periodo Protopalacial (1900 - 1700 a.C.). Tese (Doutorado) - FFLCH USP, São Paulo, 1997.

AllegretTe, A.H. - Aspectos da Urbanização nos Sítios Palaciais Minóicos do Período Protopalacial (1900-1700 a.C.). USP, São Paulo, 2002

BIERS, William R. - The Archaeology of Greece: An Introduction. Ithaca/London, Cornell University Press, 1987.

BRANIGAN, K. - The Foundations of Palatial Crete. London, Western Printing Services Ltd., 1970.

CADOGAN, G. - Palaces of Minoan Crete. New York, Methuen, 1976.

CHAPOUTHIER, F. e CHARBONNEAUX, J. - Palais: Premier Rapport, Exploration du Palais. Mallia: Fouilles Exécutées à Mallia. Librairie Orientaliste Paul Geuthner, Paris, 1928. (Études Crétoises, I)

CHAPOUTHIER, F. e JOLY, R. - Palais II: Deuxiéme Rapport, Exploration du Palais. Mallia: Fouilles Exécutées à Mallia. Librairie Orientaliste Paul Geuthner, Paris, 1936. (Études Crétoises, IV) 
CHAPOUTHIER, F. e DEMARGNE, P. - Palais: Troisiéme Rapport, Exploration du Palais. Mallia: Fouilles Exécutées à Mallia. Librairie Orientaliste Paul Geuthner, Paris, 1942. (Études Crétoises, VI)

CHAPOUTHIER, F. e DEMARGNE, P. e DESSENNE, A. - Palais: Quatriéme Rapport, Exploration du Palais. Mallia: Fouilles Exécutées à Mallia. Librairie Orientaliste Paul Geuthner, Paris, 1962. (Études Crétoises, XII)

DEMARGNE, P. \& GALLET DE SANTERRE, H., - Mallia, maisons I (1921-1948). Athènes, Paul Geuthner, 1953. (Études Crétoises, $I X$.)

DESHAYES, J. \& DESSENNE, A. - Mallia, maisons II (1948-1954). Athènes, Paul Geuthner, 1959. (Études Crétoises, XI).

DOUMAS, C. G. - Thera, Pompeii of Ancient Aegean. Editora Thames and Hudson, London, 1984.

DRIESSEN, J. - The minoan hall in domestic architecture on Crete: to be en vogue in LM Ia? $A A L, 21,1982$, p.27-92.

DRIESSEN, J. - Earthquake-resistant construction and the wrath of the "Earth-Shaker". JSAH 46, 1987, p.171-178.

DRIESSEN, J. - The proliferation of minoan palatial architectural style: (I) Crete. AAL, 28/29, 1988-89, p.3-23.

ECO, U. - A Estrutura Ausente. São Paulo, Editora Perspectiva, 2003. (série Estudos, 6)

EFFENTERRE, H. Van et alii - Mallia, site (1956-57) et nécropoles II (1915-1928). Athènes, Paul Geuthner, 1963. (Études Crétoises, XIII)

EFFENTERRE, H. Van - Le palais de Mallia et la cité minoenne. Rome, Ed. dell'Ateneo, $1980,2 \mathrm{v}$. 
EFFENTERRE, H. Van - Les fonctions palatiales dans la Crète minoenne. Le Système Palatial, 1987, p.173-185.

ERNEST, B. - O Espelho Mágico de M.R. Escher. Berlin, Taschen, 1991.

FLANNERY, K. V. e MARCUS, J. - Cognitive Archaeology. In PRENCEL, R. E HODDER, I (Eds.) Contemporary Archaeology in Theory . Oxford, Blackwell Publishers, 1996, p. 351363

GRAHAM, J.W. - The Palaces of Crete. New Jersey, Princeton University Press, 1962.

GRAHAM, J.W. - Further Notes on Minoan Palace Architecture: 1. West Magazines and Upper Halls at Knossos and Mallia; 2. Access to, and Use of Minoan Palace Roofs. AJA 83, 1979 p. $49-69$

HAGG, Robin \& MARINATOS, Nanno (Eds.) - Sanctuaries and cults in the Aegean Bronze Age. Proceedings of the First International Symposium at the Swedish School in Athens 1980. Stockholm, Paul Astrom, 1981,

HAGG, Robin \& MARINATOS, Nanno (Eds.) - The Functions of the Minoan Palaces. Proceedings of the Fourth International Symposium at the Swedish Institute in Athens - 1984. Stockholm, Paul Astrom, 1987.

HALLAGER, E. - Upper floor in LM I houses. HEP, 1990, p.281-292.

HALlAGER, Birgitta P.- A "Harvest Festival Room" in the minoan palace? An architectural study of the Pillar Crypt area at Knossos. FMP, 1987, p.169-177.

HANSMANN, C. R. - Las Escaleras en la Arquitectura. Barcelona, Editorial Gustavo Gili, 1994.

HOOD, S. - Os Minóicos. Lisboa, Editorial Verbo, 1971.

HUGON, A. - Cálculos e Ensaios. Estudos de Projetos de Construção. Editora Hemus, São Paulo, s.d. 
KARETSOU, A. - The Peak Sanctuary of Mt. Juktas. Sanctuaries, 1981 p. 137-153

KNAPP, A. B., ASHMORE, W. - Archaeology Landscapes: Construted, Conceptualize, Ideational. Archaeologies of Landscape, Contemporary Perspectives. Knapp, A. B., Ashmore, W. (Eds.) Blackwell Publishers Inc, Massachusetts, 1999.

KENT, S. (Ed.)- Domestic Architecture and the use of space. An interdisciplinary crosscultural study. Cambridge, Cambridge University Press, 1990. (s. New Directions in Archaeology)

LAWRENCE, Denise L. - The Built Environment and Spatial Form. ARA, 1990, p. 453-505

MALLIA: Plans du site, plan du palais, indices. Paris, Paul Geuthner, 1974, 65 p. + plantas. (Études Crétoises, XIX).

MICHAILIDOU, A. - The settlement of Akrotiri (Thera): a theoretical approach to the function of the upper storey. HEP, 1990, p.293-306.

MCENROE, J. - A typology of Minoan Neopalatial Houses. AJA 86(1):3-19, 1982.

TEIXEIRA NETTO, J.Coelho - A construção do sentido na arquitetura. São Paulo, Editora Perspectiva, 1999. (Coleção Debates)

NUET, A.U. I. - La Escalera. Barcelona, Editorial Gustavo Gili, 1994.

PALYVOU, C. - Circulatory Patterns in Minoan Architecture. FMP, 1987 p. 195-203

PALYVOU, C. - Monuments of Minos, Rethinking the Minoan Palaces - DRIESSEN, Jan; SCHOEP, Ilse \& LAFFINEUR, Robert (Eds.) - Proceedings of the International Workshop "Crete of The Hundred Palaces?" Université Catholique de Louvain, Louvain-la-Neuve. AEGAEUM 23, p. 167-177, 2001

PEARSON, M. P. \& RICHARDS, Colin - Ordering the World: Perceptions of Architecture, Space and Time. Architecture and Order: Approaches to Social Space. PEARSON, M. P. \& 
RICHARDS, Colin (Eds.) London/New York, Routledge, 1994, p. 1-37. (Material Cultures Series)

PELON, Olivier - Le palais de Mallia V. Paris, Paul Geuthner, 1980, 2 v. (Études Crétoises, XXV)

PELON, Olivier- Guide de Mallia. Le palais et la nécropole de Chrysolakkos. EFA/De Boccard, 1992. (Sites et Monuments, IX)

PELON, Oliver - Monuments of Minos, Rethinking the Minoan Palaces - DRIESSEN, Jan; SCHOEP, Ilse \& LAFFINEUR, Robert (Eds.) - Proceedings of the International Workshop "Crete of The Hundred Palaces?" Université Catholique de Louvain, Louvain-la-Neuve. AEGAEUM 23, p. 111 - 120, 2001

POURSAT, J-C. - La ville minoenne de Mallia: recherches et publications récentes. RA 1:61$82,1988$.

POURSAT, J-C. - Guide de Mallia. Le quartier Mu. EFA/De Boccard, 1992. (Sites et Monuments, VIII)

POURSAT, J-C. - Artisans Minoens: Les Maisons-Ateliers du Quartier Mu: Fouilles Exécutées à Mallia. Librairie Orientaliste Paul Geuthner, Paris, 1996. (Études Crétoises, XXXII)

PREZIOSI, Donald - Minoan architectural design. Berlin, Mouton, 1983, (Approaches to Semiotics 63)

RAPOPORT, A. - House Form and Culture. Prentice-Hall, INC., Englewood Cliffs, N.J. 1969.

RAPOPORT, A. - Human Aspects of Urban Form. Towards a Man-Environment Approach to Urban Form and Design. Pergamon Press Ltd., Oxford, 1977. 
RENFREW, Colin - Towards a Cognitive Archaeology. In RENFREW, Colin e ZUBROW, E.B.W. (Eds) The Ancient Mind, Elements of Cognitive Archaeology. Cambridge, Cambridge University Press, 1994, p. 3-27 (s. New Directions in Archaeology)

RENFREW, Colin e BAHN, Paul Archaeology: Theories, Methods and Practice. London, Thames \& Hudson, 2000.

RUTKOWSKI, B. - The cult places of the Aegean. London, Yale University Press, 1986.

SAKELLARAKIS, Yannis \& SAKELLARAKIS, Efi-Sapouna - Archanes. Minoan Crete in a new light. s.1., Ammos Publications/Eleni Nakou Foundation, 1997, v. 1.

SANDERS, D. - Behavioral Conventions and Archaeology: methods for analysis of ancient Architecture. In KENT, S. (Ed.)- Domestic Architecture and the Use of Space. An Interdisciplinary Study. Kent, Susan (Ed) Cambridge, Cambridge University Press, 1990 p. $43-72$

SCHOEP, I. - "Home Sweet Home" Some Comments on the So-Called House Models from the Prehellenic Aegean. OpAth XX:13, 1994, p.189-210

SHAW, Joseph W. - Minoan Architeture: Materials and Techniques. Roma, Instituto Poligrafico Dello Stato, 1973.

WARREN, P. - Creta. CD-ROM, São Paulo, Studio Interativo, 1998.

WATROUS, Lance V. - The role of the Near East in rise of the Cretan palaces. FMP, $1987 \mathrm{p}$. $65-70$

WATROUS, Lance V. - Review of Aegean Prehistory III: Crete from Earliest Prehistory Through the Protopalacial Period. AJA 98, 1994, p. 695-753

WHITELAW, T.M. - The settlement at Fournou Korifi, Myrtos and aspects of Early Minoan social organization. Minoan Society, 1983, p.332-345.

Referência eletrônica 1: 
http://www.phil.unierlangen.de/ plaltar/ausstellung_html/lectures_html/archanes/archanesI b_shot1.jpg

Referência eletrônica 2:

http://www.phil.unierlangen.de/ p1altar/ausstellung_html/lectures_html/archanes/archanes1 b_shot1.jpg 


\section{LISTA DE FIGURAS}

1. Localização da ilha de Creta.p.9

2. Ilha de Creta e suas cidades. p.10

3. Limite da cidade de Mália (DEMARGNE e SANTERRE, 1921-48, pl.1) p.12

4. Semelhança de um "quebra-cabeça"; contudo Hallager aponta nessa imagem somente a ala oeste dos palácios de Cnossos, Mália, Festos e Zacro, mostrando a orientação do pátio central e padrões de salas na mesma ala (HALLAGER, 1987, p.174). p.19

5. Uma reconstituição do Minoan Hall (DRIESSEN, 1982, p. 28). p.20

6. Casa Delta Alfa, Mália. Minoan Hall sala 5 (DRIESSEN, 1982, p. 49).p.20

7. Fundação, Tilissos (SHAW, 1973, p. 143). p.22

8. Fundação, Vasiliki (SHAW, 1973, p. 77). p.22

9. Sala lustral, quadra III do palácio de Mália (MALLIA, 1929-35, pl. IV). p.27

10. Quadra Delta (PREZIOSI, 1983, fig. 14). p.28

11. Casa Zeta beta (DESHAYES e DESSENNE, 1948-54, pl. II).p.29

12. Planta de localização da Cripta Hipostila e da Ágora (EFFENTERRE, 1962, fig. 265).34

13. Plaquetas de fiança. p.36

14. Estampa de um selo representando um edificio e seus pavimentos superiores (Referência Eletrônica 1 httpccwf.cc.utexas.edu perlmanmythmaster.html).p.38

15. Afresco, viagem de Flotilha (DOUMAS, 1983, fig. X). p.39

16. Continuação Afresco, viagem de Flotilha (DOUMAS, 1983, fig. X). p.39

S/Numeração - Modelo de Arcanes de vários ângulos, reconstituição virtual. Referência eletrônica 2:

http://www.phil.unierlangen.de/ p1altar/ausstellung_html/lectures_html/archanes/archanes1b _shot1.jpg.p.40

17. Setor norte do palácio de Amarna, Egito. Salas com pilares (GRAHAM, 1962, fig. 149). p. 41

18. Palácio de Mália, proposta de Graham do pavimento superior sala de Recepção. Planta térrea, acima, parte das quadras I e VIII. Planta do pavimento superior, abaixo (1962, fig. 83 e 84). p. 42

19. Palácio de Cnossos, pavimento superior, restauração Evans. Planta térrea, acima, parte das quadras I e VIII. Planta do pavimento superior, abaixo (GRAHAM, 1962, fig. 83 e 84). p.42

20. Perspectiva tridimensional do palácio de Mália, segundo Graham (1962, fig. 58) p.43

21. Perspectiva tridimensional do palácio de Mália, segundo Effenterre. (1980, fig. 457) p.43 
22. Maquete do palácio de Mália (SCHMID, 1996).p.44

23. Perspectiva da oficina de olaria, segundo Poursat (1996, fig.22). p.45

24. Seção de uma parede da quadra I do palácio de Mália (SHAW, 1973, p.78) p.50

25. Paredes do palácio de Mália (SHAW, 1973, p. 190). p.51

26. Parede da Oficina de Cerâmica, quadra Mu.p.53

27. Recosntituição da fachada sul do pátio central do palácio de Mália (CHAPOUTHIER e JOLY, 1925- 26, pl. III.).p.54

28. Paredes das áreas I 2 e I 3, palácio de Mália. p.55

29. Piso em placas da sala lustral do palácio de Mália.p.56

30. Relatividade, litografia, Escher, 1953 (ERNEST, 1991, fig.95). p.61

31. Modelo de Arcanes (SAKELLARAKIS, 1997, fig. 564). p.62

32. Escadas tipo U, L e I. p. 65

33. Grande Escadaria do palácio de Cnossos, quadra residencial. p.65

34. Processo construtivo de uma escadaria, exemplo sugerido para Arcanes (SAKELLARAKIS, 1997, dwg.13) p.66

35. Cáculo da inclinação de algumas escadarias do palácio de Mália, segundo Van Effenterre (1980, fig.306).p.68

36. Desenhos de vãos para cada tipo de escadarias, I, L e U. p.69

37. Quadra Zeta (DESHAYES e DESSENNE, 1948-54). p.73

38. Planta com paredes restouradas da casa Zeta Alfa (DEMARGNE E SANTERRE, 1921-1948, pl. LXVI). E localização da escadaria. p.75

39. Perspectiva interna da casa Zeta Alfa, segundo Presiozi (1983, fig. I.13). p.76

40. Casa Zeta beta (DESHAYES e DESSENNE, 1948-54, pl. II) e localização das escadas. p.78

41. Foto do área I, Zeta Beta, mostrando o corredor e vão da escadaria. p.79

42. Perspectiva interna da casa Zeta Beta, segundo Presiozi (1983, fig. II.1.6). p.81

43. Quadra Delta (DEMARGNE e SANTERRE, 1921-48, pl. LXVII).p.82

44. Casa Delta Beta mostrando os blocos e localização das escadarias (DEMARGNE E SANTERRE, 1921-48, pl. LXV) p.84

45. Peça 13, vão da escadaria do bloco central, casa Delta Beta. p. 85

46. Degraus in loco entre as peças 10 e 11, casa Delta Alfa. p.88

47. Casa Delta Alfa e locolização da escadaria 44: Casa Delta Beta mostrando os blocos e localização das escadarias (DEMARGNE E SANTERRE, 1921-48, pl. LXVII).p.89 
48. Soleira na entrada da peça 12, casa Delta Alfa. p.90

49. Planta da casa Épsilon e localização das escadarias (EFFENTERRE, 1980, fig. 553). p.92

50. Poço da escadaria, peça 25, casa Épsilon. p.94

51. Quadra Mu (POURSAT, 1996). p.95

52. Quadra Mu, casa Mu A e localização das escadarias (POURSAT, 1996). p.98

53. Escadaria I A com degraus in loco, Casa Mu A p.100

54. Escadaria II B com degraus in loco, Casa Mu A p.101

55. Quadra Mu, casa Mu B e localização das escadarias (POURSAT, 1996). p.103

56. Escadaria e degraus da IV A, casa Mu B. p.104

57. Escadaria IV B, Casa Mu B. p.105

58. Planta da Cripta Hipostila e localização das escadarias (EFFENTERRE, 1980, fig. 265). p.108

59. À esquerda escadaria 1, entrada, e à direita escadaria 2, Cripta Hipostila. p.109

60. Poço da escadaria 3, Cripta Hipostila. p.110

61. Reconstituição segundo Amouretti, cortes da Cripta Hipostila (AMOURETTI, 1957-62). p.111

62. Planta do palácio de Mália e localização das quadras e áreas das escadarias. p.112

63. Quadra I, bastião A, I 2 e I 3, suposto poço de escada, I 4 e I 6, contrafortes. p.113

64. Quadra I, palácio de Mália. Área I 2, à esquerda e área I 3, à direita. p.114

65. Quadra II p.116

66. Quadra II, palácio de Mália. Peças II 1 a, b e c. p.117

67. Quadra IV, peças IV 7 e IV 8. p.118

68. Planta reconstituição segundo Ven Effenterre (1980, fig.423). p.120

69. Planta das peças IV 7 e IV 8 (MALLIA, 1974). p.120

70. Quadra VI. p.121

71. Planta e corte da escadaria (CHAPOUTHIER e CHARBONNEAUX, 1922-24, fig. 31). p.122

72. Grande Escadaria, vista do pátio central. p.123

73. Recosntituição da escadaria VI, segundo Ven Effenterre. Linhas contínuas, degraus existentes; pontilhadas reconstituição (EFFENTERRE, 1980, p.310). 123

74. Quadra XVI. p.125

75. Planta da escadaria Monumental (CHAPORTIER e JOLY, 1925-26, p. 14-18). p.125 
76. Escadaria Monumental, vista do pátio central. p.126

77. Quadra IX.p. 128

78. Planta quadra IX (PELON, 1980, fig. 12). p.129

79. Escadaria IX, vista do pátio central. p.129

80. Reconstituição da escadaria IX, segundo Van Effenterre (1980, fig.421). p.130

81. Quadra XIII.p.132

82. Planta da quadra XIII (MALLIA, 1974). p.133

83. Reconstituição escadaria XIII, segundo Ven Effenterre (1980, fig.417). p.134

84. Quadra XVII. p.135

85. Quadra XVII, escadaria norte. p.136

86. Quadra XIX, peças XIX 7, XIX 8 e bastião H. p.137

87. Quadras XXI e XXII. p.138

88. Peça XXII 2, à esquerda e à direita XXI 2. p.139

89. Proposta, segundo Graham, do pavimento superior e suas respectivas escadarias, acima das quadras IX, XXI e XXII, acessos à sala de banquete (1979, ILL.8). p.140

90. Quadras XXI e XXII. p.141

91. Planta reconstituição, segundo Van Effenterre (1980, fig.416). p.142

92. Quadra XXVII. p.143

93. Quadra XXVII (MALLIA, 1974). p.144

94. Planta de reconstituição das oficinas da quadra Mu (Poursat, 1996, fig.53). p.147

95. Fachada oeste, escadaria quadra III (MAQUETE, 1996). p.151

96. Fachada oeste, escadaria quadra I (MAQUETE, 1996). p.151

97. Fachada sul, escadaria quadra XIV(MAQUETE, 1996). p.152

98. Fachada leste, escadaria quadra XXVI (MAQUETE, 1996). p.152

99. Fachada norte, escadaria do pátio norte (MAQUETE, 1996). p.153

100.Fachada pátio central, escadarias: Monumental e Grande Escadaria (MAQUETE, 1996). p.153

101. Esquemas: fachada do palácio, à esquerda; fachada residencial, à direita. p.159 
